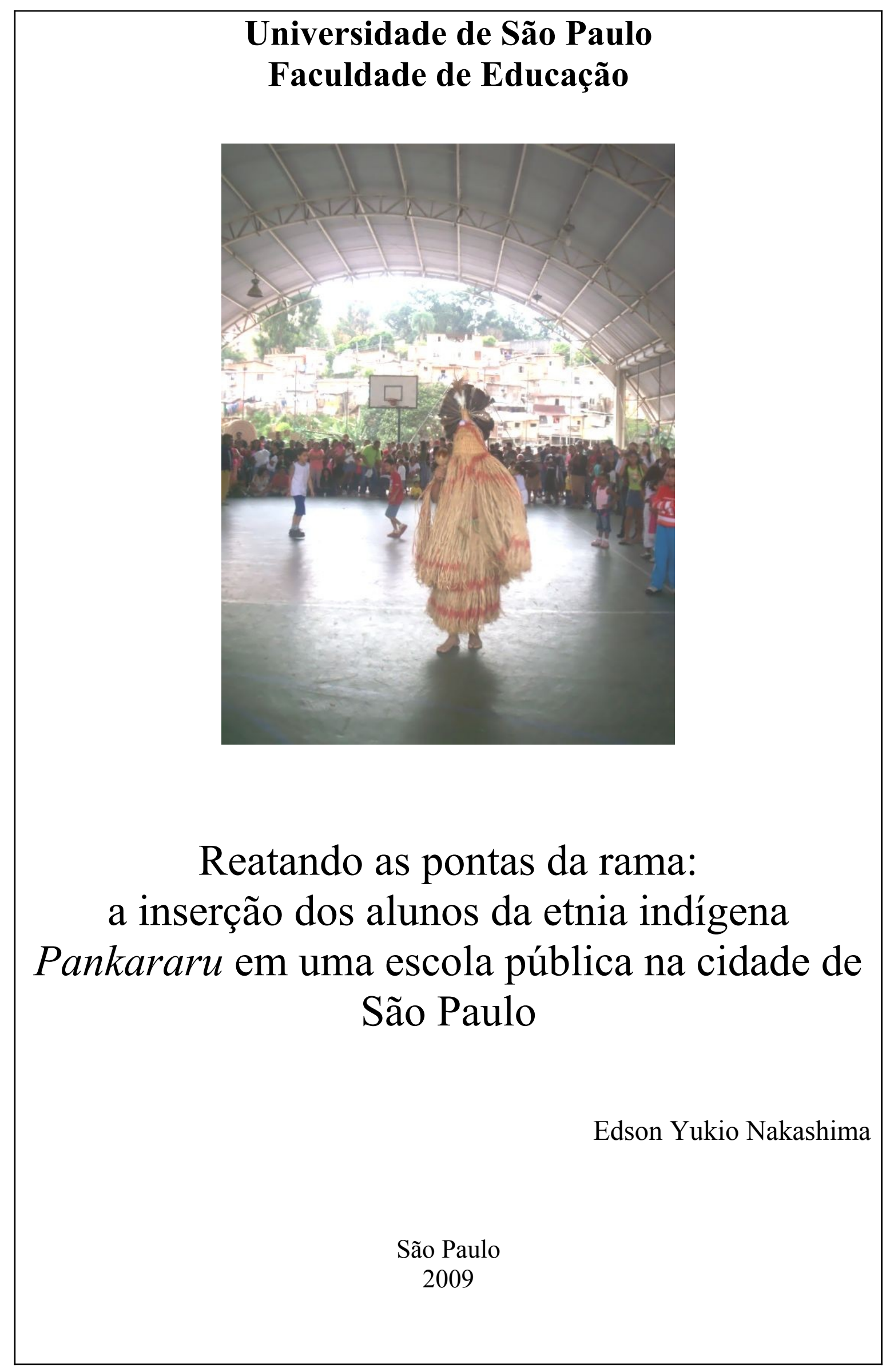


Edson Yukio Nakashima

\title{
Reatando as pontas da rama: \\ a inserção dos alunos da etnia indígena \\ Pankararu em uma escola pública na cidade de São Paulo
}

\author{
Dissertação de Mestrado apresentada \\ ao Programa de Pós-Graduação em \\ Educação da Faculdade de Educação \\ da USP, para obtenção do título de \\ Mestre em Educação. \\ Área de concentração: Psicologia e \\ Educação.
}

Orientadora: Prof ${ }^{a}$. Dr ${ }^{\mathrm{a}}$. Mônica do Amaral

São Paulo

2009 
AUTORIZO A REPRODUÇÃO E DIVULGAÇÃO TOTAL OU PARCIAL DESTE TRABALHO, POR QUALQUER MEIO CONVENCIONAL OU ELETRÔNICO, PARA FINS DE ESTUDO E PESQUISA, DESDE QUE CITADA A FONTE.

Catalogação na Publicação

Serviço de Biblioteca e Documentação

Faculdade de Educação da Universidade de São Paulo

371.97

Nakashima, Edson Yukio

N163r

Reatando as pontas da rama: a inserção dos alunos da etnia indígena Pankararu em uma escola pública na cidade de São Paulo / Edson Yukio Nakashima; orientação Mônica do Amaral. -- São Paulo: s.n., 2009.

248 p. il; anexos

Dissertação (Mestrado - Programa de Pós-Graduação em Educação. Área de Concentração: Psicologia e Educação) - - Faculdade de Educação da Universidade de São Paulo.

1. Educação indígena 2. Psicologia social 3. Identidade 4. Diversidade cultural 5. Preconceito e discriminação I. Amaral, Mônica do, orient. 


\section{FOLHA DE APROVAÇÃO}

Edson Yukio Nakashima

Reatando as pontas da rama: a inserção dos alunos da etnia indígena Pankararu em uma escola pública na cidade de São Paulo.

Dissertação de Mestrado apresentada ao Programa de Pós-Graduação da Faculdade de Educação da USP, para obtenção do título de Mestre em Educação.

Área de concentração: Psicologia e Educação.

Aprovado em:

\section{Banca Examinadora}

Prof $^{a}$. Dr ${ }^{\mathrm{a}}$. Mônica do Amaral

Instituição: FE-USP

Assinatura:

Prof. Dr. José Sérgio Fonseca de Carvalho

Instituição: FE-USP

Assinatura:

Prof ${ }^{a}$. Dr ${ }^{\mathrm{a}}$. Leila Salomão de La Plata Cury Tardivo

Instituição: IP-USP

Assinatura: 


\section{Dedicatória}

Dedico este trabalho à comunidade Pankararu do Real Parque. Espero que este trabalho esteja à altura de todos os esforços resistentes e persistentes desprendidos por eles diante dos desafios que se apresentam na luta pelos direitos, pela cultura e pela identidade indígena neste país.

Também dedico a Hiroshi e Mitiko Nakashima, meus pais. 


\section{Agradecimentos}

Minha profunda gratidão à...

... minha esposa Sandra, cujo amor, amizade, paciência e apoio nos momentos mais difíceis foram cruciais para que este trabalho pudesse ser realizado. É um privilégio têla como minha companheira nessa caminhada.

... minha família - mãe, irmãos, sogra, cunhados e sobrinhos -, que também sempre me apoiaram nos momentos mais difíceis.

... Dora, Seu Bino e Dona Ninha, e toda a comunidade Pankararu. Sem o apoio deles, este trabalho não teria se concretizado.

... minha orientadora, Prof ${ }^{a}$. Mônica do Amaral, que tem perseverado em me orientar desde a iniciação científica, apesar de toda a "trabalheira" dada. Com paciência e firmeza, tem me auxiliado a prosseguir na vida acadêmica.

... Tati, pela amizade e pelas infindáveis caronas, conversas - acadêmicas ou não -, leituras de trabalho e apoio de todas as formas e em todos os momentos.

... Luiz, Maira e Patrícia, por todos os momentos compartilhados no Projeto. Obrigado por todo o apoio e ajuda em todos os sentidos.

... Marcos Albuquerque, pela amizade criada e por todo o diálogo teórico e de campo, que deu novo alento à minha pesquisa. Que o trabalho em conjunto continue a dar frutos.

... aos professores da EMEF Alcântara participantes do Projeto, em especial Silas, Cecília, Ana e Marina.

... aos professores da USP José Sérgio Fonseca de Carvalho e Leila Tardivo, que muito contribuíram com suas observações na qualificação.

... à Sandra Almeida, pela amizade, pela leitura e sugestões ao meu trabalho.

... a todos os meus amigos, que sabendo ou não, fazem parte da minha vida e do meu trabalho.

Agradeço também à FAPESP pelo apoio prestado à minha pesquisa, à realização da I Semana de Diversidade e Cultura e na apresentação dos trabalhos em conferências. 


\section{Epígrafe}

\section{Rap dos Pankararu}

Eu mando nossa rima

É logo de supetão

Tá ligado, meu irmão

Rei, capitão eu sou

Pankararu tá ligado

Meu irmão

Eu vim da Bahia

Agora estou no Real

Sul agora todas as

pessoas me conhecem

como Pankararu!!!

Eu moro no Real Sul

Quase me esqueci

Que sou é Pankararu!

\section{Luciara e Alexia ${ }^{1}$}

\section{Identidade}

Preciso ser um outro

para ser eu mesmo

Sou grão de rocha

sou o vento que a desgasta

Sou pólen sem insecto

Sou areia sustentando

o sexo das árvores

Existo onde me desconheço aguardando pelo meu passado ansiando a esperança do futuro

No mundo que combato morro

no mundo por que luto nasço

Mia Couto ${ }^{2}$

\footnotetext{
${ }^{1}$ Alunas Pankararu da $3^{\mathrm{a} E}$ da EMEF Alcântara.

${ }^{2}$ COUTO, Mia. Raiz de Orvalho e outros poemas. Lisboa: Caminho, 1999.
} 


\section{Resumo}

NAKASHIMA, Edson Yukio. Reatando as pontas da rama: a inserção dos alunos da etnia indígena Pankararu em uma escola pública na cidade de São Paulo. 2009. 255 p. Dissertação (mestrado) - Faculdade de Educação, Universidade de São Paulo, São Paulo, 2009.

A presente dissertação de mestrado teve como objetivo pesquisar a inserção de alunos da etnia indígena Pankararu em uma escola municipal da cidade de São Paulo, que atende aos jovens moradores dos bairros Jardim Panorama, Paraisópolis e Real Parque. Uma peculiaridade dessas localidades é a existência de uma comunidade indígena Pankararu, o que nos direcionou a estudar um fenômeno social recente: os indígenas urbanos. Migrantes de terras tradicionais do Nordeste, em que vivenciaram um processo histórico de emergência étnica, os Pankararu vêm se constituindo na cidade de São Paulo como um grupo étnico politicamente atuante que, por meio de suas associações, têm reivindicado direitos diferenciados para sua etnia na metrópole. $\mathrm{O}$ estudo acerca da realidade vivida pelos Pankararu esteve ancorado em diversos estudos antropológicos a respeito dos indígenas do Nordeste (Arruti e Oliveira Filho), além de uma pesquisa documental, acompanhamento e registro das atividades da comunidade Pankararu de São Paulo. Como método de pesquisa na escola, que incluiu questionários e intervenções em sala de aula em conjunto com professores da escola, foi adotado o "olho participante", de Massimo Canevacci, a partir do qual pudemos obter uma ampla compreensão da realidade vivida pelos alunos Pankararu na escola. O trabalho com os professores envolveu tentativas sucessivas de constituição de comunidades interpretativas (Boaventura Santos), no interior das quais fosse possível repensar suas visões de mundo e práticas pedagógicas, podendo assumir então o papel de intelectuais transformadores (Henry Giroux). As pesquisas evidenciaram a marginalização e exclusão da cultura indígena da ordem hegemônica da cultura escolar, além da predominância de uma visão marcada pela representação estereotipada dos indígenas, que tem contribuído para fomentar a discriminação dos alunos Pankararu. Em decorrência disso, observamos uma relação ambivalente dos alunos Pankararu com sua própria identidade étnica, seja por não possuírem um sentimento de pertença à comunidade, seja por não desejarem se declarar como indígenas na escola. Uma atitude que é possivelmente expressão de uma autodefesa, em razão do receio da discriminação exercida sobre eles pela comunidade escolar. Tornou-se assim evidente que as escolas presentes em um contexto urbano não estão preparadas pedagogicamente para acolher estudantes de etnias minoritárias de modo a respeitar suas culturas, tradições e identidades peculiares.Como forma de reverter este quadro, foi realizada uma Semana de Diversidade e Cultura, cuja organização incluiu a própria comunidade Pankararu, pesquisadores e corpo docente, tendo como objetivo instituir um diálogo entre as culturas indígenas e afro-brasileiras e a cultura escolar por meio de debates sobre a legislação que obriga o ensino da história e culturas indígenas e afro-brasileiras. Foram ainda realizadas diversas atividades com os alunos e a comunidade, abordando as produções culturais e formas de organização política da comunidade Pankararu na cidade. Os resultados dessa Semana foram importantes para a afirmação étnica dos alunos Pankararu, assim como uma maior conscientização dos alunos não-indígenas a respeito da temática indígena e afro-brasileira, mas evidenciaram também a necessidade de se repensar os princípios norteadores das práticas da escola pública.

Palavras-chave: educação indígena - psicologia social - identidade - diversidade cultural - preconceito e discriminação 


\begin{abstract}
NAKASHIMA, Edson Yukio. Reconnecting branches to trunk: the insertion of Pankararu indigenous students in a public school of São Paulo city. 2009. 248 p. Dissertation (Master degree) - Faculdade de Educação, Universidade de São Paulo, São Paulo, 2009.

The present dissertation aimed to research the integration of students from a Pankararu indigenous ethnic group in a public school in São Paulo, which usually receives the youth living in the neighborhoods of Jardim Panorama, Paraisopolis and Real Parque. These regions' peculiarity is their indigenous community Pankararu which led us to study a recent social phenomenon: the urban Brazilian Indians. They migrated from traditional lands in the Northeast of Brazil where they had lived a historical process of ethnic emergency. They have established in São Paulo city as an ethnic group politically engaged who has demanded special rights in the metropolis by means of associations. This study about Pankararu's living reality is anchored in several anthropological studies about the indigenous people from the Northeast of Brazil (Arruti and Oliveira Filho) in addition to researches on documentation and follow-up and records of Pankararu community's activities in São Paulo. At school the methodology included questionnaires and intervention in class along with the teachers - the "participating look [regard in French]" by Massimo Canevacci was adopted in order to have broader understanding of the reality as lived by Pankararu students at school. The work with the teachers involved successive attempts to form interpretive communities (Boaventura Santos), inside which they would be able to think over their views of the world and pedagogical practices in order to take up their role of transformative intellectuals (Henry Giroux). The surveys brought to light the marginalization and exclusion of the indigenous culture from the hegemonic school culture, as well as the predominance of a view marked by the stereotyped representation of the Indians which has contributed to promote Pankararu students' discrimination. Face to this we observed an ambivalent relation of Pankararu students with their own ethnic identity, either because they feel they don't belong to the community or because they don't want to call themselves Indians at school. This attitude is probably their expression of self-defense as they are afraid of suffering discrimination by the school community. Therefore it was clearly shown that the schools in an urban context are not pedagogically prepared to welcome students from ethnical minorities in a way their peculiar culture, tradition and identity are respected. An attempt to reverse this picture was the organization of the Week on Diversity and Culture including Pankararu community, researchers and teachers with the intention to promote a dialogue among the Indigenous and African-Brazilian cultures and school culture by means of a debate about the legislation which established as obligatory the teaching of Indigenous and African-Brazilian history and culture. Also, several activities were performed with the students and the community about Pankararu's cultural production and forms of political organization in the city. This Week's results were important to Pankararu students' ethnic affirmation as well as nonIndians' awareness of the Indigenous and African-Brazilian theme, but also revealed the need to think over the principles guiding the practices at public school.
\end{abstract}

Key-words: indigenous education - social psychology - identity - cultural diversity prejudice and discrimination 


\section{Sumário}

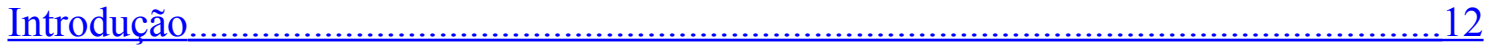

1. A emergência étnica dos indígenas Pankararu no Nordeste.........................................20

A problemática da terra e a subsistência dos indígenas Pankararu..............................21

As condições de saúde...............................................................................................23

Organização comunitária e faccionalismo.............................................................24

Uma interpretação histórico-social da emergência étnica dos Pankararu...................25

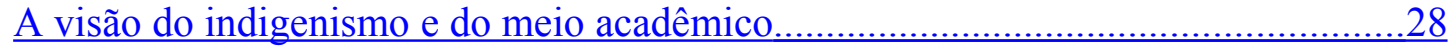

Os caminhos da emergência étnica......................................................................30

Os indígenas do Nordeste ....................................................................................32

Uma acepção moderna de cultura e a etnicidade Pankararu........................................34

A invenção das tradições...................................................................................... 38

A mobilização étnica Pankararu.................................................................................40

O ritual do Toré: elemento constitutivo da identidade Pankararu..............................43

O ensino do Toré ..................................................................................................47

A música Pankararu.............................................................................................48

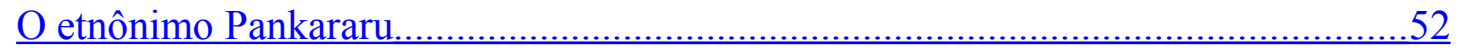

As metáforas da emergência étnica...........................................................................55

A relação entre "Enxames" e "Levantamento de aldeias"........................................55

A relação entre os "Troncos velhos" e as "Pontas de Rama".....................................55

2. Indígenas na cidade - Os Pankararu de São Paulo...………………………………….....57

Os Pankararu de São Paulo...............................................................................61

A população Pankararu em São Paulo...………………………………………………65

As associações indígenas.....................................................................................67

Os caminhos da visibilidade....................................................................................71

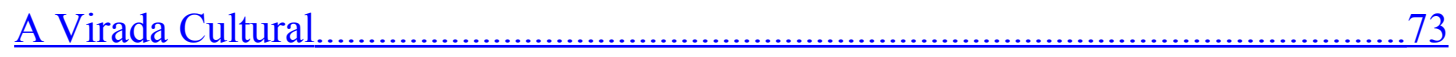

A busca por uma reterritorialização étnica.....................................................................76

Ouvindo a voz dos que não têm vez?......................................................................8

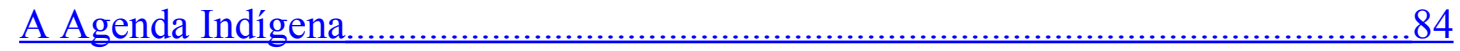

Direitos indígenas diferenciados..............................................................................88

A consolidação dos direitos adquiridos......................................................................90

Os critérios de identidade étnica.......................................................................93

3. O bairro Real Parque e a EMEF José de Alcântara Machado Filho............................95

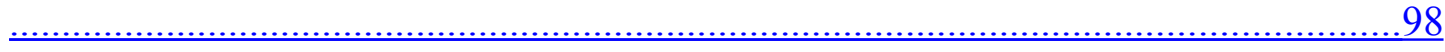

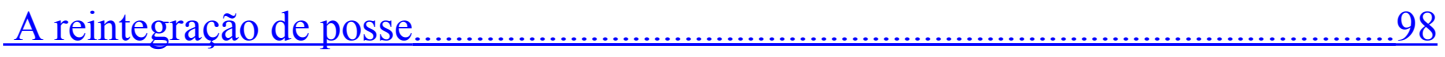

A reivindicação dos moradores da comunidade do bairro Real Parque.......................99

A EMEF Alcântara..........................................................................................101

Uma educação à deriva..............................................................................................102

A falta "de" professores ou "dos" professores - ou ambos?.......................................103

A quebra de autoridade ..........................................................................................105

A questão do "letramento".........................................................................................105

Participação da comunidade na escola.................................................................106

Uma escola de ensino médio...................................................................................107

4. A temática indígena nas escolas..............................................................................109

A pluralidade cultural como tema transversal............................................................113

A elaboração do questionário ..............................................................................120

A metodologia de análise do questionário...............................................................120

A síntese da avaliação dos questionários..................................................................122 


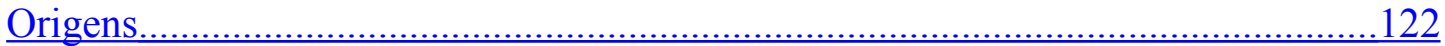

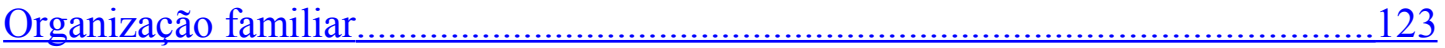

A escola e as suas representações.....................................................................123

O conceito de cultura por parte dos alunos...........................................................124

A existência de alunos Pankararu na escola....................................................126

Uma visão estereotipada dos indígenas.......................................................128

A cultura escolar e os "currículos turísticos" ....................................................133

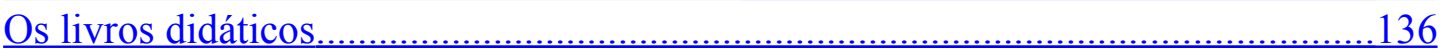

5. Um estudo mais detido: intervenções na classe " $7^{\mathrm{a}} \mathrm{B}$ " .......................................142

$\underline{\text { A visão dos alunos sobre os Pankararu............................................................... } 142}$

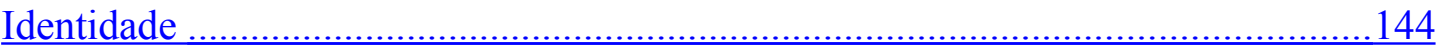

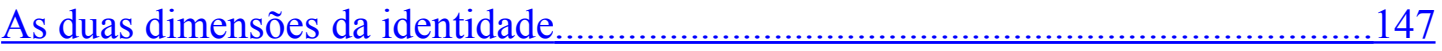

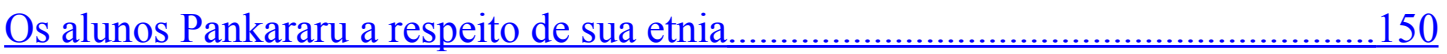

"Com os Pankararu, eu danço, canto, aprendo e, às vezes, ensino"........................150

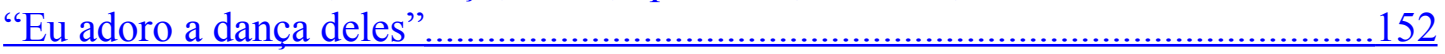

"Eles cantam em outra língua" .....................................................................153

"As comidas deles não são diferentes das nossas"............................................... 155

Observações gerais sobre as alunas Pankararu.....................................................155

A metodologia das intervenções......................................................................157

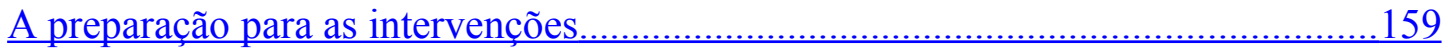

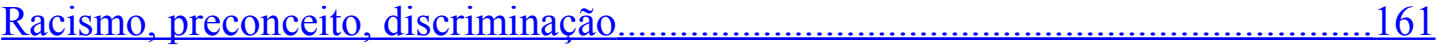

Os tipos de racismos.................................................................................... 162

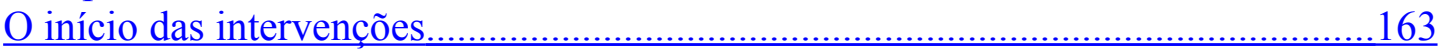

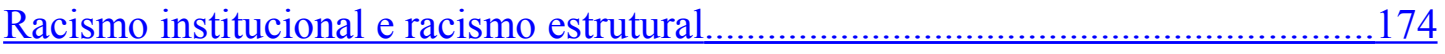

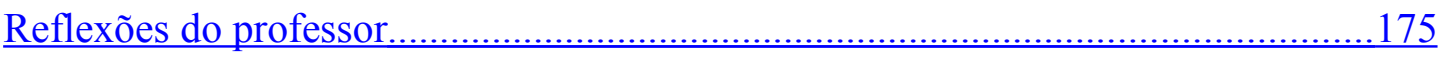

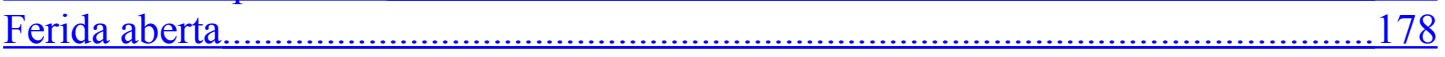

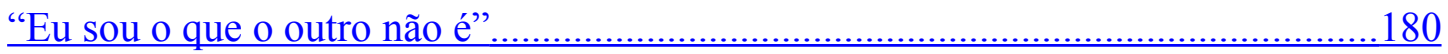

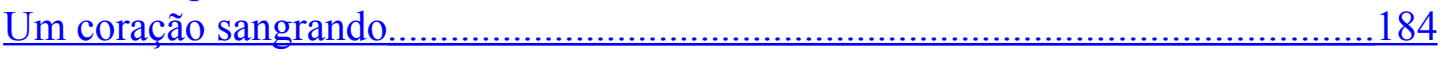

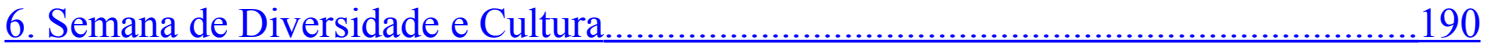

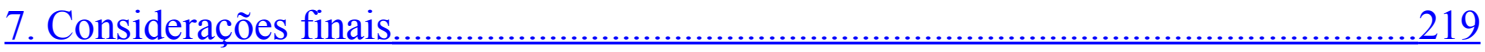

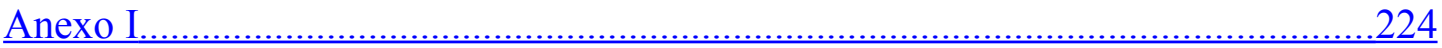

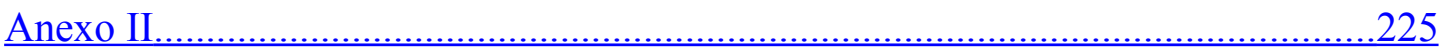

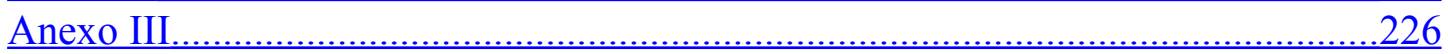

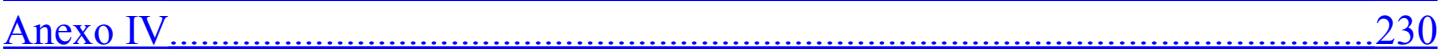

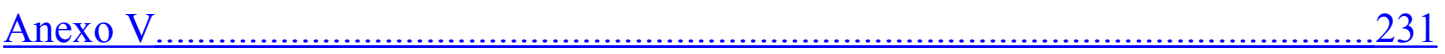

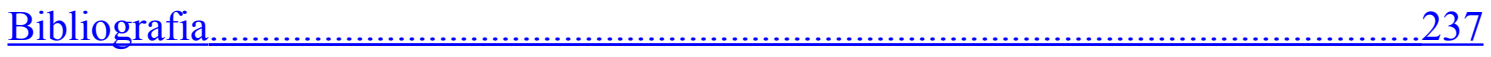




\section{Introdução}

A presente dissertação de mestrado teve a intenção de estudar o tipo e o grau de inserção dos alunos da etnia indígena Pankararu em uma escola municipal da cidade de São Paulo. Faz parte do Projeto de Melhoria do Ensino Público Culturas juvenis $x$ cultura escolar: como repensar as noções de tradição e autoridade no âmbito da educação? (Fapesp, 2006-2008) , coordenado pela Prof $^{\mathrm{a}}$. Drª . Mônica do Amaral, cujo objetivo era investigar em que medida a cultura escolar poderia se beneficiar de uma aproximação intelectual e afetiva do amplo espectro de manifestações culturais juvenis, contribuindo, desse modo, para repensar questões que permanecem problemáticas na relação entre professores e alunos, com ênfase no declínio da autoridade do professor (cf. Amaral, 2006).

Antes de desenvolver a temática da dissertação, gostaríamos de relatar brevemente o nosso percurso até a escolha do objeto de pesquisa. No ano de 2005, realizamos um projeto de iniciação científica intitulado Reconstrução da narratividade entre alunos do ensino médio, sob orientação da Prof $f^{\mathrm{a}}$. Mônica do Amaral. Com base em uma abordagem multidisciplinar (psicologia social, psicanálise, filosofia e literatura) e fundamentando-se nos estudos teóricos de Walter Benjamin (1985) a respeito do declínio da narratividade no mundo moderno, iniciamos uma pesquisa de campo em uma escola de ensino médio da rede estadual de São Paulo para averiguar de que maneira o citado declínio estaria afetando a estruturação narcísica ${ }^{4}$ do jovem contemporâneo, em especial entre os alunos do ensino médio.

Esta pesquisa de campo nos permitiu, por meio das atividades desenvolvidas, um contato maior com os alunos adolescentes. De fato, o que se tornou evidente na pesquisa foram as conseqüências do declínio da narratividade no contexto escolar, destacando-se dentre elas a fragilidade desta estruturação narcísica nos jovens no contexto contemporâneo (cf. Jeammet, 2005). Em meio a ambientes sufocantes e tão pouco atentos às suas demandas (na escola, na família e na sociedade em geral), os adolescentes com os quais convivemos - têm buscado trilhar um caminho de autoafirmação e de construção de uma identidade. Alguns deles buscam essa afirmação por

\footnotetext{
${ }^{3}$ Para maior facilidade de leitura, a menção a este projeto, nesta dissertação, será feita como: Projeto Culturas Juvenis.

${ }^{4}$ Segundo o psicanalista $\mathrm{Ph}$. Jeammet (2005), é a estruturação narcísica que proporciona sentimento de segurança e o sentido de continuidade de si para o indivíduo. Essa estruturação é constituída desde a infância, em decorrência de um intercâmbio afetivo que a criança estabelece com o mundo dos adultos, sendo de fundamental importância para o seu desenvolvimento psicossocial.
} 
meio do agir criativo e da elaboração psíquica, mas muitos outros recorrem às passagens ao ato - as denominadas patologias do $\operatorname{agir}^{5}$ - como tentativa de construir sua identidade (cf. Jeammet, 2005).

Observarmos, ainda, a necessidade premente de os adultos oferecerem apoio ao desenvolvimento destes adolescentes, uma vez que o contexto social complexo no qual estão inseridos (a intensificação das tendências narcísicas, a perda dos limites, a liberalidade dos costumes e o declínio progressivo do sentimento de dever social) os têm colocado em situações bastante difíceis de desamparo, quando não, de abandono (a si mesmos). Essas problemáticas, ao serem verificadas em uma escola freqüentada por alunos de classe média, tendem a se acentuar nas classes menos privilegiadas. A delinqüência, a alta mortalidade dos jovens, a toxicomania, os níveis de "indisciplina" e violência nas escolas e outros distúrbios são sintomas claros da necessidade de mobilização dos adultos em torno da formação emocional e cultural dos adolescentes. Estas conclusões nos estimularam a repensar o objeto de pesquisa, ampliando-o para um contexto social mais amplo, que envolvesse tanto a escola quanto o grupo social que compõe a comunidade ao redor da escola ${ }^{6}$.

A partir desta vivência, iniciei minha participação no Projeto Culturas Juvenis, que foi realizada de outubro de 2006 a setembro de 2008 na EMEF José de Alcântara Machado Filho ${ }^{7}$, localizada na região sul da cidade de São Paulo, que atende às comunidades do Jardim Panorama, Paraisópolis e Real Parque. Como participante deste projeto, integrei inicialmente um subgrupo formado por alguns professores da própria escola, cujo objetivo era pesquisar as culturas juvenis presentes nesta instituição. A participação nesse projeto possibilitou um contato maior com estas comunidades presentes no entorno da escola, o que permitiu conhecer com maior profundidade o contexto social no qual elas vivem. Uma peculiaridade das comunidades no entorno da

\footnotetext{
${ }^{5}$ Segundo Jeammet (2005), a patologia do agir - ou agir patológico -, presente na função protetora do narcisismo e da identidade, possui uma função anti-introjetiva e corresponde a um trabalho de expulsão e de busca do controle no exterior, no mundo perceptivo-motor, daquilo que não pode ser controlado a nível intrapsíquico. É essencialmente defensivo e de curta duração.

${ }^{6}$ No projeto anterior, havíamos proposto um trabalho junto à comunidade Pankararu utilizando como método de reconstrução da narratividade, uma experiência de intercâmbio entre culturas tradicionais - a do próprio pesquisador (cultura oriental-japonesa) e a dos Pankararu -, e também a utilização da literatura como instrumento de reconstrução da narratividade (haicais e a obra de Mário de Andrade). A idéia de intercâmbio foi aventada para evitarmos qualquer perspectiva etnocêntrica no nosso contato com a cultura tradicional Pankararu. Já no caso da literatura, ela foi pensada como um meio de promover a reconstrução de uma narratividade que estaria em declínio e também como instrumento de formação do indivíduo.

${ }^{7}$ Para maior facilidade de leitura, a partir deste momento denominaremos esta escola como EMEF Alcântara.
} 
EMEF Alcântara é a existência de uma comunidade indígena Pankararu, fato que nos despertou a atenção.

A chegada de indígenas aos centros urbanos traz à tona um fenômeno social recente e ainda não devidamente pesquisado: os indígenas na cidade. A população de indígenas Pankararu na cidade de São Paulo surgiu a partir dos deslocamentos de trabalhadores desta etnia do Nordeste, especificamente da Terra Indígena Pankararu ${ }^{8}$, para as grandes cidades do Sudeste a partir da década de 1940-50. Inicialmente, o êxodo foi motivado pela invasão de posseiros na Terra Indígena, o que provavelmente trouxe dificuldades de subsistência a essa comunidade indígena. Em função disso, muitos deles foram obrigados a se retirar de suas terras de origem em busca de sobrevivência e migraram para as grandes cidades.

Conhecendo melhor o contexto social deste grupo étnico, decidimos redirecionar a pesquisa que já havia sido realizada no projeto de iniciação científica para a realidade específica dos jovens Pankararu. Tomamos essa decisão, motivados pelo interesse em conhecer o modo de vida de uma comunidade indígena em um contexto urbano, que, além de enfrentar condições precárias de subsistência, possui o desafio de preservar sua cultura e tradições em um ambiente bastante adverso. Essa decisão ampliou em muito o escopo e a complexidade do objeto de nosso estudo e incluiu uma série de temáticas a serem abordadas, como, por exemplo, as questões de cultura, identidade e discriminação social $^{9}$. Os jovens Pankararu moradores da cidade de São Paulo se colocam no centro deste grande dilema, pois, além de trazerem consigo, muitas vezes, elementos tradicionais em sua formação, também precisam conviver com as exigências que a sobrevivência em uma cidade grande lhes impõe: a inserção no mercado de trabalho, os ditames do consumo, a convivência com uma visão de mundo totalmente diversa, como a que está presente na escola e que resulta muitas vezes em preconceito dos pares com os quais convive, com costumes e valores muito distantes dos de sua etnia de origem.

Para ter acesso aos aspectos acima mencionados, formou-se o subgrupo de pesquisa, composto por pesquisadores da Faculdade de Educação da USP e professores da EMEF Alcântara, que se propôs a realizar um estudo da inserção dos jovens alunos

\footnotetext{
${ }^{8}$ As terras indígenas dos Pankararu se encontram no lugar denominado genericamente como Brejo dos Padres, localizado próximo às margens do Rio São Francisco e situado entre os atuais municípios de Petrolândia, Jatobá e Tacaratu, na porção semi-árida do Estado de Pernambuco.

${ }^{9}$ Uma outra questão que me atraiu no estudo dessa comunidade foi a constituição da identidade étnica por parte dos jovens indígenas Pankararu. A identificação com o tema se deve ao meu histórico pessoal: sou descendente de japoneses e, portanto, possuo uma herança cultural nipônica. No entanto, convivo com o desafio de estabelecer uma identidade cultural específica em meu próprio país, o Brasil.
} 
Pankararu no ambiente escolar. Foram realizadas inicialmente atividades em sala de aula com os alunos da escola, que nos proporcionaram subsídios para formular, juntamente com o grupo dos professores e demais pesquisadores do projeto, um amplo questionário que pudesse contemplar as manifestações culturais, os interesses, as necessidades e anseios dos alunos em relação ao futuro ${ }^{10}$.

A análise dos questionários, sob supervisão da Prof ${ }^{\mathrm{a}}$. Mônica do Amaral, envolveu um longo e árduo trabalho em conjunto entre professores e pesquisadores e nos proporcionou um quadro amplo da realidade social vivida pelos alunos dessa escola. Com base nele, os subgrupos de pesquisa foram então reformulados com o intuito de atender as questões mais significativas observadas na escola. Desse modo, um subgrupo tinha como objetivo específico compreender a situação dos alunos Pankararu nesta escola. Isso se deve ao fato de termos observado, na análise dos questionários, uma grande dificuldade dos alunos de descendência Pankararu de se identificarem etnicamente como indígenas, o que nos levou à necessidade de concentrarmos nossas pesquisas especificamente neste aspecto.

O subgrupo iniciou suas atividades no mês de agosto de 2007 e passou a realizar intervenções em sala de aula na " $7^{\mathrm{a}}$ B", que foram concluídas em novembro de 2007. A escolha desta classe se deveu ao fato de ela possuir mais alunos Pankararu do que as demais classes da escola. Estas intervenções nos permitiram uma maior aproximação da realidade vivida pelos alunos Pankararu na escola e nos proporcionaram uma visão abrangente a respeito da relação destes alunos com os seus colegas de classe, corpo docente e comunidade. Foi possível verificar que os alunos de origem indígena estavam sujeitos a diversas situações de preconceito e discriminação, étnica em particular, tanto no ambiente escolar, como no interior da própria comunidade em que viviam. No entanto, observou-se também que a discriminação social atingia a todos, alunos nãoindígenas e indígenas, devido ao fato de morarem em uma comunidade pobre circundada por um bairro de classe alta.

O trabalho de pesquisa com os Pankararu permitiu-nos "desconstruir" uma visão etnocêntrica e de uma determinada representação muito comumente utilizada a respeito dos indígenas. Qual seria esta representação? A do indivíduo morador da selva, que possui tecnologias rudimentares e instituições primitivas. Em geral, é esta representação que prevalece na literatura, no meio escolar e acadêmico e na jurisdição e de acordo com a qual são dirigidos a política indigenista e os mecanismos de assistência

\footnotetext{
${ }^{10}$ Este questionário contemplava também a inserção dos alunos Pankararu na escola.
} 
ao indígena (cf. Oliveira Filho, 2000). Também pudemos comprovar a necessidade de repensar as concepções de cultura e de tradição que repousam no senso comum e também na cultura escolar e que se mostraram insuficientes e inadequadas para a reflexão das condições e do contexto social dos indígenas Pankararu.

Além disso, Clarice Cohn (2001) nos esclarece que não podemos considerar as culturas indígenas como homogêneas e fechadas em si mesmas, assim como a tradição não é um corpus fechado que persiste no tempo. A transmissão da cultura e das tradições, ao contrário, convive com um processo de transformação contínua. $O$ problema surge quando esta concepção naturalizada de cultura se associa a uma representação do indígena como um indivíduo "primitivo", que povoa o imaginário das artes, das leis, da política, bem como os mecanismos de proteção ao indígena e a cultura escolar. Essa representação passa a ser utilizada, mesmo que com o intuito de defesa dos indígenas em geral, como um argumento para se suspeitar da existência de "índios" no Nordeste (uma vez que foram considerados "integrados" ou "assimilados") ou mesmo nas grandes cidades (com o argumento de que os indígenas, ao migrarem para as cidades, perderiam sua cultura e identidade étnica).

Estudos antropológicos mais recentes sustentam a idéia de que as culturas indígenas não se perdem e que as sociedades indígenas sempre estariam atuando na reconstituição de uma identidade diferenciada. Uma demonstração desta tese é a de que, após a Constituição de 1988 - quando se concedeu o direito à terra e à diferença cultural aos indígenas -, foi verificado um notável incremento da população indígena e uma emergência de etnias tidas como desaparecidas, como a dos Pankararu.

No tocante aos aspectos pedagógicos, a educação escolar indígena passou a ser um tema bastante discutido nos meios acadêmicos e nos órgãos governamentais. No entanto, os estudos se restringem a escolas denominadas indígenas (inseridas nas terras tradicionais) e, com a inserção de indígenas nas escolas das cidades, o quadro se torna mais complexo, pois não existe uma legislação específica a respeito de uma educação diferenciada em escolas que não sejam indígenas. A pergunta que se coloca é: as escolas não-indigenas estariam preparadas pedagogicamente para acolher estudantes de etnias minoritárias, como é o caso dos indígenas Pankararu, de modo a respeitar as peculiaridades de sua cultura, tradições e identidade étnica?

Como cenário elucidativo desta situação, nas pesquisas realizadas na EMEF Alcântara, observamos que muitos dos alunos não-indígenas desconhecem por completo a existência de indígenas Pankararu na comunidade e na própria escola que estudam 
(cf. Amaral, 2007). Trata-se de um fenômeno que exige nossa atenção, pois há uma população Pankararu considerável na comunidade do Real Parque e na escola. Além disso, alunos não-indígenas demonstram ainda possuir uma visão naturalizada do indígena, que é aquela de um indivíduo habitante da selva e amante da natureza, sem se darem conta de que eles possuem as mesmas condições de vida no mesmo bairro em que estes mesmos alunos moram. Essas visões vêm provavelmente da representação estereotipada dos indígenas, muito difundida por uma cultura escolar distanciada dos debates a respeito a respeito da diversidade cultural. Como podemos observar, a concepção do senso comum de um indivíduo "primitivo" acaba se voltando justamente contra os próprios indígenas que habitam nas grandes cidades, contribuindo para uma situação propícia ao preconceito e à discriminação, uma vez que a figura do indígena assume uma conotação negativa perante alunos e professores.

Entretanto, o que mais chamou a atenção dos pesquisadores foi o fato de que, entre os alunos que afirmam possuir uma descendência indígena, foram poucos os que se reconheceram efetivamente como Pankararu. Os próprios alunos que afirmavam descender de pais Pankararu aparentam conhecer pouco ou até mesmo desconhecer sua cultura e seus costumes, tratando o tema como se fosse alheio às suas vidas ou parecendo tomar distância em relação às suas origens. Pudemos observar uma relação ambivalente dos alunos com a sua identidade étnica, seja por não possuírem um sentimento de pertença à comunidade indígena, seja por não desejarem se declarar como indígenas na escola como expressão de uma possível autodefesa, em razão do receio da discriminação exercida sobre os indígenas, tanto por parte dos alunos como do próprio corpo docente. Segundo o antropólogo Stephen Baines (2001), a identidade indígena nas cidades é freqüentemente escamoteada como estratégia adotada para escapar dos preconceitos e estigmas, configurando-se como uma identidade social contextual, em que uma mesma pessoa pode se considerar indígena em alguns contextos, e não em outros, ou apelar a outras identidades genéricas.

No entanto, apesar dessas dificuldades de identificação, outros alunos Pankararu afirmam sua identidade étnica em razão de direitos diferenciados oriundos de sua própria etnicidade, como podemos ver no seguinte depoimento: "Sou Pankararu e tenho oportunidade de estudar sem pagar". Isso é explicado pelo fato de uma universidade em São Paulo ${ }^{11}$ oferecer bolsas para que os Pankararu possam freqüentar e se formar no espaço acadêmico, beneficiando diversos de seus membros. Nesse sentido,

\footnotetext{
${ }^{11}$ A PUC/São Paulo, por meio do Projeto Pindorama, proporciona bolsas para universitários indígenas.
} 
assumir uma identidade Pankararu proporciona uma espécie de instrumentalidade social que pode contribuir para a afirmação étnica do grupo, bem como para uma inserção na sociedade urbana.

Nesse caso, evidencia-se a marginalização ou exclusão da cultura indígena ou das chamadas minorias étnicas da ordem hegemônica da cultura escolar. Questiona-se, então, em que medida a cultura escolar tem auxiliado a menosprezar a cultura ou identidade étnica dos alunos indígenas ou mesmo auxiliado a contribuir para a discriminação social de alunos da classe desprivilegiada e de sociedades minoritárias. Além disso, os próprios problemas estruturais e pedagógicos que a EMEF Alcântara tem enfrentado também produzem uma série de desafios no processo de aprendizado e letramento dos alunos de um modo geral, incluindo os alunos Pankararu.

Passamos agora à descrição de como pretendemos realizar a apresentação desta dissertação de mestrado. É preciso esclarecer que, embora nosso objeto de pesquisa esteja direcionado a alunos da etnia indígena Pankararu em uma escola municipal de São Paulo, não é nosso objetivo realizar um trabalho antropológico, mas sim utilizar instrumentos que a antropologia oferece para compreender a cultura e as tradições Pankararu, além de averiguar se a escola pública tem contribuído (ou não) para a valorização das culturas e identidades indígenas.

No capítulo 1, A emergência étnica dos indígenas Pankararu no Nordeste, buscamos apresentar um quadro das condições de vida deste grupo étnico no Nordeste, sua origem histórico-social e o processo de emergência étnica pela qual eles atravessaram até chegar aos tempos atuais. Para isso, utilizamo-nos de diversos trabalhos antropológicos que se debruçaram sobre a questão dos indígenas do Nordeste.

Já no capítulo 2, Indígenas na cidade - Os Pankararu de São Paulo, a fim de compreender a questão dos indígenas na cidade, analisamos a migração dos Pankararu do Nordeste para o Sudeste, bem como as transformações que ocorreram no decorrer dessa transição histórico-espacial. Assim, com base em uma pesquisa documental, depoimentos colhidos entre os membros da etnia Pankararu do Real Parque e acompanhamento e registro das atividades realizadas por eles, obtivemos um quadro amplo da mobilização étnica promovida pelos Pankararu por meio de suas associações na busca por um atendimento diferenciado nas áreas da saúde, educação e cultura realizados na cidade de São Paulo.

No capítulo 3, O bairro Real Parque e a EMEF Jose de Alcântara Machado Filho, procuramos caracterizar o bairro onde se concentra grande parte da população 
Pankararu, como modo de retratar as "reais condições"12 de vida destes indígenas em São Paulo e também apresentar um panorama das condições e dos desafios enfrentados pela EMEF Alcântara, escola em que a maior parte dos alunos Pankararu estudam.

Em relação ao capítulo 4, A temática indígena nas escolas, buscamos explorar as discussões teóricas a respeito da questão da pluralidade cultural no plano pedagógico, principalmente as que são expostas nos Parâmetros Curriculares Nacionais (como tema transversal), e a sua efetiva contribuição aos conteúdos curriculares presentes nas escolas. Para tanto, expusemos os resultados da análise dos questionários que foram aplicados a alunos da EMEF Alcântara (e sua metodologia de análise), que nos apresentaram um quadro real da efetividade do trabalho da conscientização da pluralidade cultural no interior da escola.

No capítulo 5, Um estudo mais detido: intervenções na classe " $7{ }^{a}$ B", descrevemos as intervenções realizadas pelo grupo de pesquisadores em uma classe específica da EMEF Alcântara, que nos proporcionaram um quadro amplo da discriminação sofrida pelos alunos desta escola em geral, e as conseqüências deste processo discriminatório para a subjetividade e afirmação étnica dos alunos Pankararu.

O capítulo 6, A Semana de Diversidade e Cultura, descreve a Semana de atividades realizadas na EMEF Alcântara. Trata-se de um trabalho em conjunto que envolveu a própria comunidade Pankararu, pesquisadores acadêmicos e escola, cujo intuito era inserir, no interior da própria escola, o diálogo a respeito da história e da cultura indígena, em especial a dos Pankararu. Este trabalho foi realizado por meio da discussão da legislação de obrigatoriedade do ensino de histórias e culturas afrobrasileiras, além de diversas atividades e debates que buscavam contemplar a diversidade cultural na escola. Pretendemos, com este capítulo, sintetizar todas as discussões realizadas e apresentar as considerações finais desta dissertação de mestrado.

\footnotetext{
12 Colocamos ênfase nas "reais condições", pois a situação precária na qual os indígenas vivem permanece oculta ou distorcida pela mídia.
} 


\section{A emergência étnica dos indígenas Pankararu no Nordeste}

Os Pankararu fazem parte de um dos oito grupos indígenas que habitam o estado de Pernambuco e vivem no interior semi-árido numa região denominada Vale do São Francisco, na área de influência do Baixo-Médio Rio São Francisco, em um território circundado pelos municípios de Petrolândia, Tacaratu e Jatobá. Segundo Mauro (2007), dos territórios originais que os Pankararu ocupavam no Nordeste apenas um território de 15.927 hectares subsiste hoje e está distribuído em duas terras indígenas:

- Terra Indígena Pankararu, demarcada pelo Serviço de Proteção ao Índio (SPI) em 1940 e homologada em 1987 pelo governo brasileiro, possuindo uma área total de 8.377,28 hectares que está distribuída em 15 aldeias: Brejo dos Padres, Caldeirão, Espinheiro, Carapateira, Barrução, Saco dos Barros, Olaria, Cacheados, Logradouro, Tapera, Agreste, Macaco, Barriguda, Saco do Porcão e Bem Querer;

- Terra Indígena Entre Serras, com uma extensão de 7.750 hectares, foi homologada em 2006.

Estas duas terras indígenas ocupam uma área contínua que apresenta um formato regular, mas seus processos de identificação ocorreram em épocas distintas, de modo que a área de Entre Serras acabou sendo homologada como segunda terra indígena e não como complementação da primeira. Segundo estimativas do levantamento realizado pela Fundação Nacional de Saúde (FUNASA), a população residente nas terras indígenas está calculada em aproximadamente em seis mil indivíduos (cf. Mauro, 2007).

De acordo com Mauro (2007), devido ao intenso e contínuo grau de contato com elementos da sociedade circundante, os Pankararu estão bastante miscigenados e desprovidos de uma forte contrastividade cultural (Oliveira Filho, 1998) em relação a esta sociedade, em especial em relação à população rural sertaneja. Assim como grande parte dos indígenas presentes no Nordeste, falam unicamente a língua portuguesa, em razão de, nos tempos coloniais, terem sido proibidos de falar sua língua materna. De seu idioma tradicional restaram algumas palavras, que são cantadas em suas manifestações culturais. Também possuem acesso aos veículos de comunicação de massa como a 
televisão, o rádio e também a Internet, sendo, portanto, informados e influenciados pelas informações e conteúdos veiculados por esses meios. Em razão da presença prolongada de missionários católicos em suas terras, iniciada no século XVII, eles são, em boa parte, adeptos da fé cristã, que é praticada nas igrejas católicas e protestantes presentes em suas aldeias.

Esses são um dos motivos que fazem com que os Pankararu sejam estigmatizados e tenham sua identidade indígena constantemente colocada em cheque pela sociedade majoritária. Embora os dados apresentados de fato indiquem a integração dos Pankararu na sociedade nacional, eles não confirmam a tese de que foram completamente assimilados. "Os Pankararu possuem em comum um sentimento de pertencimento a uma população de ancestralidade pré-colombiana, étnica e culturalmente diferenciada dos demais brasileiros, e os traços mais fortes de sua afirmação identitária são as práticas de rituais como o Toré e a crença na força sobrenatural dos Encantados" (Mauro, 2007, p. 112). Sendo assim, embora os Pankararu se assemelhem à população sertaneja presente no entorno de suas terras, isso não deslegitima a sua identidade como povo indígena.

\section{A problemática da terra e a subsistência dos indígenas Pankararu}

São os conflitos fundiários e a conseqüente insuficiência de terras os fatores que promovem as precárias condições às quais estão submetidos os povos indígenas do Nordeste, acarretando problemas nas áreas da saúde e da alimentação. Pode-se verificar que as condições de vida dos Pankararu são bem preocupantes em diversos aspectos, como saúde, educação, a questão da terra, o trabalho e o meio ambiente, do mesmo modo que muitas das populações rurais que habitam o Nordeste brasileiro. A subsistência dos indígenas Pankararu, assim como dos demais grupos indígenas de Pernambuco, se dá por meio da agricultura e, em alguns casos isolados, por meio da criação de gado bovino e caprino, para consumo próprio em sua maioria.

A dieta dos Pankararu é composta pela carne vermelha (suínos, caprinos, ovinos e bovinos) e a carne de frango, provenientes de animais criados pelas famílias. Já na produção agrícola, destaca-se o plantio da mandioca, milho, feijão, batata-doce, além de frutas como umbu, manga, côco, melancia e pinha. Além disso, verifica-se a produção de Palma, cactácea utilizada como ração para animais. Embora haja a proximidade das terras indígenas com o Rio São Francisco, são poucos os que sobrevivem 
exclusivamente da pesca. Outras alternativas de renda se dão por meio de trabalho assalariado nas pequenas e grandes cidades. São muitos também os Pankararu que confeccionam e vivem da venda de itens de artesanato (adereços como colares, brincos e pulseiras; artigos de cerâmica e os envolvem trabalhos de tecelagem, como redes, tapetes e bolsas), que são expostos em feiras nas cidades vizinhas (cf. Mauro, 2007).

De acordo com Cunha (2007), a problemática da terra assume grande importância no caso dos indígenas do Nordeste porque é ela que possui a potencialidade de proporcionar a sobrevivência e a continuidade étnica destes povos. A fertilidade natural dos solos cultivados é afetada em razão de seu uso intensivo, decorrente de alta densidade populacional e também em razão da disputa com posseiros que invadiram as terras indígenas, intensificando a competição por sua posse e usufruto dos recursos naturais. Os conflitos fundiários sempre foram determinantes nesta localidade, no entanto, a construção da Usina Hidroelétrica de Itaparica agravou a situação, atingindo as cidades de Petrolândia/PE e Glória/BA. Conseqüentemente, mais de cinco mil famílias de trabalhadores rurais foram desalojadas da região, o que intensificou as invasões nas terras indígenas, acirrando os conflitos na região. Assim, de um lado, observou-se a presença de posseiros, fazendeiros e de projetos desenvolvimentistas nas terras indígenas, o que vem gerando o problema da insuficiência da terra; de outro, nos territórios já regularizados e ocupados, as terras são consideradas as menos férteis, quadro que se agrava com os períodos prolongados de secas/estiagem que atingem a maioria destas áreas.

Com suas terras sofrendo o impacto cíclico das secas e dos movimentos climáticos peculiares ao semi-árido nordestino, a população Pankararu encontra-se em processo acelerado e gradativo de empobrecimento. A busca pela água torna-se uma atividade fundamental para a sobrevivência da população, demandando esforços contínuos de seus membros, problema que nem a proximidade de algumas de suas terras do Rio São Francisco é capaz de resolver, condição que faz com que esta população seja incluída no mapa da fome. Vários dos córregos que perpassam o território secam completamente no período de estiagem. Com isso, muitas famílias ficam ainda na dependência dos caminhões-pipa das prefeituras para o acesso à água potável. Assim, durante a seca, alguns membros desta população recebem cestas básicas do programa assistencial do Governo (cf. Cunha, 2007).

A exploração intensiva dos recursos naturais do território indígena e a caça predatória, realizadas em grande parte pelos posseiros e invasores, fazem com que os 
animais, que eram a base de alimentação dos Pankararu, se escasseiem cada vez mais, alguns estando em vias de extinção. Além disso, a degradação ambiental também tem prejudicado a obtenção de matérias-primas que seriam utilizadas para o artesanato, como a palha de buriti, a madeira e o barro (cf. Mauro, 2007).

\section{As condições de saúde}

De acordo com Mauro (2007), a falta de condições apropriadas de saneamento básico é um problema que vem acarretando diversos problemas de saúde para a população Pankararu. Pouquíssimas casas nas aldeias possuem tratamento de esgoto e muitas delas nem possuem sanitários. O lixo, por falta de serviços de coleta nas aldeias, é queimado ou fica exposto a céu aberto. Devido a isso, muitas nascentes de água que abastecem a população estão sendo contaminadas pelos detritos, decorrendo daí a proliferação de doenças de pele, diarréia e infecções.

Também problemas de saúde como hipertensão, diabetes e pressão elevada têm aparecido entre os habitantes. A motivação do surgimento dessas doenças se deve provavelmente ao aumento do consumo de produtos industrializados, que são ricos em sal, açúcares e gordura, em razão também da diminuição dos alimentos tradicionais que eram ingeridos pela comunidade. O tabagismo também é um fator que deve ser contado para esse aumento.

Um grave e crônico problema de saúde que tem acometido também as comunidades Pankararu nas terras indígenas é o alcoolismo, atingindo principalmente a população masculina, e de modo cada vez mais freqüente, os menores de idade. A questão é decorrente, dentre outros fatores, da falta de perspectivas de ascensão social, principalmente devido à falta de oportunidades de trabalho, além de carências de atividades esportivas, cultura e lazer, assim como falta de equipamentos e espaços próprios para a realização destas atividades. Conta-se também a facilidade com que os indígenas, principalmente os menores de idade, estão tendo acesso às bebidas nos bares, em geral, que acabam por se transformar, na falta de alternativas, em espaços de socialização e também de brigas.

Embora sejam observados todos estes problemas, os indígenas têm tido diversas dificuldades para marcar consultas e obter medicamentos nos postos locais da FUNASA, problema bastante recorrente, aliás, em todos os serviços prestados em território nacional por este órgão governamental. Embora os Pankararu recorram ao 
serviço público de saúde, isso não quer dizer que a medicina tradicional Pankararu venha sendo desprezada. Ela continua sendo praticada com bastante intensidade, principalmente em razão da cultura deste povo estar bastante associada à crença do poder de cura dos Encantados, entidades sobrenaturais que, na cosmovisão dos Pankararu, protegem e zelam pela comunidade. Desse modo, verifica-se a existência de rezadeiras, Praiás, pajés e curadores que praticam a medicina tradicional por meio de ervas e plantas (cf. Mauro, 2007).

\section{Organização comunitária e faccionalismo}

Segundo Mauro (2007), uma das dificuldades com que os Pankararu têm se defrontado também é o faccionalismo e divergências existentes entre as lideranças, que se agravaram em razão da homologação tardia da $\mathrm{TI}^{13}$ Entre Serras que, embora seja contínua com a TI Pankararu, está caracterizada como uma terra separada. Com o surgimento de uma nova liderança na TI Entre Serras, vê-se então uma polarização entre duas forças políticas que vem se antagonizando de forma irreconciliável em virtude de interesses divergentes. Além disso, verificam-se outros focos de divergência: muitos têm pleiteado uma identidade étnica, mas não têm sido reconhecidos como indígenas pelas lideranças tradicionais Pankararu, havendo então uma tensão entre os que desejam o reconhecimento, mas que são acusados de oportunistas, e as lideranças tradicionais, que estariam sendo acusadas de negar um direito legítimo de autoafirmação indígena; além disso, em Brejo dos Padres, considerada a maior e a mais representativa dentre as aldeias, observa-se que mais de uma pessoa se apresenta como cacique, havendo então um não-reconhecimento mútuo e a competição entre as lideranças Pankararu. Outro foco de disputa é que existe apenas um posto indígena da FUNAI, instalado em 1940, para atender às reivindicações dos indígenas e ele está situado somente na TI Pankararu, gerando reivindicações por parte dos Pankararu da TI Entre Serras para que se instale um posto indígena em seu próprio território. Logicamente, as divisões entre os Pankararu acabam por restringir quaisquer tentativas de se promover melhorias para a comunidade local em geral.

Embora se verifiquem as cisões mencionadas, elas se restringem, na maior parte das vezes, apenas aos que exercem ou assumem alguma função de liderança entre as comunidades. Entre os membros das comunidades em si, existe o desejo de que haja

\footnotetext{
${ }^{13}$ Terra Indígena.
} 
uma maior união e cooperação entre os próprios Pankararu para que possam fazer valer os direitos garantidos pela legislação a respeito dos indígenas e consolidar os que já foram adquiridos. Um dos modos pelos quais os Pankararu têm buscado se organizar são as associações comunitárias, que se tornam instrumentos eficazes para angariar recursos governamentais e não-governamentais para a realização de projetos de desenvolvimento para a comunidade, com ênfase para se buscar um melhor desempenho em atividades de produção, uma maior valorização dos conhecimentos e práticas, principalmente em se tratando de medicina tradicional; e trabalhos em prevenção de saúde (cf. Mauro, 2007).

No entanto, são muitos os desafios e os fatores que contribuem para as dificuldades das condições de vida dos indígenas Pankararu no Nordeste e que explicam o êxodo histórico a partir das décadas de 1940/50 de muitos deles para as grandes cidades.

\section{Uma interpretação histórico-social da emergência étnica dos Pankararu}

Para compreendermos a situação dos indígenas da etnia Pankararu, precisamos conhecer primeiramente a trajetória histórico-social que envolve a denominada emergência étnica dos indígenas do Nordeste, que inclui, por sua vez, o estudo do processo peculiar de colonização verificado nesta região. Podemos interpretar o fenômeno da emergência étnica como um processo que a antropologia denomina como etnogênese, ou seja, um processo de emergência histórica de uma comunidade ou povo que busca se autodefinir e reafirmar-se em relação a uma determinada herança sóciocultural, com base na reelaboração de símbolos e tradições culturais, sendo que muitas delas foram apropriadas da colonização e reinterpretadas segundo a perspectiva indígena (cf. Oliveira Filho, 1999). Para isso, recorremos aos estudos do antropólogo José Maurício Arruti a respeito dos indígenas do Nordeste, em especial da etnia Pankararu.

O território nordestino não foi colonizado da mesma forma que outras regiões do Brasil. Ou seja, não por meio do avanço de fronteiras, mas sim como resultado da movimentação irregular e não-linear, fonte da expansão múltipla e complexa, processo este marcado por avanços e retrocessos (cf. Arruti, 1995). O retrato da distribuição dos 
aldeamentos indígenas nos séculos XIX e XX é, de certo modo, conseqüência dessa movimentação irregular, principalmente ao longo do Rio São Francisco e seus afluentes.

O avanço colonial português na região teve início com a supressão do primeiro foco de resistência indígena na embocadura do Rio São Francisco, em 1572. Expedições se sucederam ao final do século XVI, até serem interrompidas em 1630, em razão da presença holandesa no Nordeste. Com a expulsão dos holandeses em 1654, o avanço pelo sertão passou a ser realizado de forma sistemática.

$\mathrm{O}$ apelo da Coroa portuguesa aos bandeirantes em busca de ouro e pedras preciosas aumentou consideravelmente o número das chamadas "bandeiras". Nas investidas iniciais dos bandeirantes, tomou lugar o conflito armado contra os indígenas, tendo como fulcro as mesmas justificativas teológicas que fundamentaram a "Guerra Santa" contra os árabes na época das Cruzadas européias. Estes conflitos se estenderam pelos séculos XVII e XVIII, contando com a firme resistência dos indígenas.

Conforme se desenvolvia a "Guerra Justa" empreendida contra os povos indígenas, povoados iam sendo estabelecidos, servindo como base de apoio para a conquista de novas terras. Estes povoados foram sendo constituídos por populações indígenas destituídas de terras originais, por homens livres pobres e também por mocambos, que então ocupavam as terras e as defendiam dos grupos indígenas beligerantes. Foi dessa forma que as grandes sesmarias foram sendo ocupadas.

Posteriormente, teria lugar a estratégia de conquista de homens e terras por meio de conversões. Dessa forma, o indígena passou a ser considerado "livre", sob a administração dos poderes eclesiásticos. Experimentavam-se assim os aldeamentos no Rio São Francisco, afastados dos centros urbanos, na década de 1650.

Em 1700, a Coroa exige do governador do estado de Pernambuco a implantação de missões religiosas, de modo a acelerar o povoamento dos sertões nordestinos, um nítido esforço do Rei em assumir e ampliar o seu espaço de ação para a colonização do interior, que anteriormente estava a cargo de proprietários privados.

No entanto, no século XVIII, a política de Marquês de Pombal em Portugal, influenciada pelo ideário do Iluminismo, iria se refletir nos rumos da política e administração da Colônia, especialmente em ações contra as ordens religiosas presentes em território colonial. Como forma de dar conta dos conflitos travados entre jesuítas e fazendeiros e com o intento de reorganizar a economia colonial, são tomadas medidas, por parte da Coroa, no sentido de retirar o poder temporal dos missionários sobre os aldeamentos existentes e transformá-los em vilas, procurando, além disso, incentivar os 
casamentos entre não-indígenas e indígenas. Tal política de miscigenação demarcou a terceira estratégia da conquista, que teve como objetivo romper o relativo isolamento dos indígenas localizados nos aldeamentos.

Por outro lado, passou a ser incentivada a ocupação dos aldeamentos por nãoindígenas, de forma a induzir a assimilação física e cultural dos índios, na tentativa de homogeneização da população. De acordo com Arruti:

Transformar em 'nacionais' as populações indígenas significava finalmente acabar com todas as figuras de reserva, seja de terra ou de mão-de-obra, que então passam a estar livres para a sua mercantilização. Tem raízes aí uma das idéias fundamentais do indigenismo, a da transformação daquelas populações em trabalhadores nacionais (Arruti, 1995, p. 15).

Com a Lei de Terras, promulgada em 1850, inicia-se uma política fundiária agressiva em relação aos aldeamentos. Assim, é instaurada, especialmente no Nordeste, a política de reunião, que consistia na extinção de aldeamentos e a realocação de populações destes aldeamentos em outros, mais populosos, com a justificativa de que havia poucos sobreviventes, mas cuja real intenção era acelerar a liberação das terras dos aldeamentos para ocupação de outras populações.

Uma vez que os indígenas foram dominados militarmente e "inseridos" nas missões, o passo seguinte seria a mestiçagem. A mestiçagem foi uma estratégia considerada eficaz por seus idealizadores no sentido de promover a extinção da identidade indígena. Mas, nesse caso, os argumentos para tais ações não seriam mais de caráter fundiário, mas sim, comportamental, uma vez que o critério observado para a sua realização seria a aparência dos indígenas e também a realização ou não das tradições, mesmo depois de uma duradoura política de repressão, conversão e mistura.

A mesma Lei das Terras daria início a uma série de ações que remodelariam a organização dos territórios nordestinos. A extinção dos aldeamentos indígenas no Nordeste, em particular em Pernambuco, deve ser compreendida dentro do contexto destas alterações que, por sua vez, formaram o quadro da reorganização dos padrões de controle e intervenção sobre a população rural nordestina.

Nesse contexto, em 1857, a Comissão de Demarcação das Terras Públicas da Capitania de Pernambuco realizou um levantamento da situação das aldeias indígenas do Estado de Pernambuco, no século XIX. Esse levantamento, por ter um propósito 
prático, apresentaria um panorama revelador e imparcial dos oito aldeamentos ainda existentes na época. Registramos aqui especificamente a referência feita na época do aldeamento do Brejo dos Padres, por ser ele a referência territorial dos indígenas Pankararu, assim descrito:

"Aldeamento de Brejo dos Padres - na comarca de Tacaratu, a 120 léguas de Recife; com uma população de 290, distribuída em 98 famílias, partilhando uma área de duas 'léguas em quadro' com donos de moendas de cana”. (1857).

A presença dos 'donos das moendas de cana' demonstra, de certo modo, a ausência de conflitos nos arrendamentos realizados no aldeamento, que então presenciava a construção de diversas moendas e o início das plantações de cana.

$\mathrm{Na}$ década de 1870, presenciou-se um acelerado desaparecimento dos aldeamentos, com a justificativa de que havia poucos indígenas como habitantes, já misturados à massa geral da população. Quanto aos indígenas Pankararu, no momento da extinção de seu aldeamento, estes presenciaram a divisão de suas terras e lotes, que foram distribuídas não apenas entre eles, mas também a "jagunços", clientes políticos dos latifundiários locais, e aos ex-escravos, que haviam acabado de ser emancipados e que estavam na eminência de se dispersarem pelo território nacional. Na memória dos Pankararu, parte destes ex-escravos teria se fixado em lotes do antigo aldeamento.

De uma só vez, o ônus da abolição negra foi descartado por meio da concessão, para os ex-escravos, de lotes que pertenciam aos aldeamentos indígenas, sendo estes extintos. Criaram-se assim reservas, locais que concentravam índios, negros e brancos, ambiente propício para a denominada "mistura" entre as populações existentes. Fechava-se assim o ciclo do processo de conquista e domínio colonial do Nordeste.

Arruti (1995) observa o silêncio das ciências sociais e da historiografia em relação às populações locais, o que pode demonstrar o "compartilhamento da vontade que fundou este ato, ou seja, de poder pensar o Brasil e os brasileiros, o Nordeste e os nordestinos, de forma global e indistinta" (Arruti, 1995, p. 22).

\section{A visão do indigenismo e do meio acadêmico}

Segundo Arruti (1995), o SPILTN (Serviço de Proteção ao Índio e Localização de Trabalhadores Nacionais), baluarte do indigenismo oficial brasileiro, surgiu em 1910 
e teve como objetivos a nacionalização do interior, a localização de mão-de-obra, a abertura de novas terras e diminuição dos custos da "fronteira" e cuja ação inicial se restringia a Santa Catarina, oeste paulista, Mato Grosso e Amazônia. O órgão acabou por assumir um papel colonizador, uma vez que tinha como funções a proteção dos indígenas e a alocação de mão-de-obra nativa no campo, sendo que ambas ocorreriam por meio do controle de acesso à propriedade e treinamento técnico da força de trabalho, o que implicava em transformar o índio em pequeno produtor rural autosuficiente e capaz de se integrar como mão-de-obra no mercado nacional.

No ano de 1918, o órgão passou a se denominar simplesmente SPI (Serviço de Proteção ao Índio, sendo retirada a sigla LTN - "Localização de Trabalhadores Nacionais", sem, no entanto, perder a sua intenção programática inicial). A estratégia adotada era baseada em uma noção de "transitoriedade", segundo a qual o "índio" era uma condição que necessitava ser superada, devendo ser, portanto, controlada pelo Estado.

O aparato criado, tanto jurídica, quanto administrativamente, teve a intenção de atrair e pacificar, ou seja, agregar os grupos indígenas que resistiam aos avanços da fronteira agrícola, sem que houvesse extermínio das populações. Uma vez que o Nordeste era uma região de colonização antiga e considerada totalmente "integrada", não se via assim espaço ou necessidade para a atuação da SPI (cf. Arruti, 1995).

A visão científica sustentada pelos pesquisadores acadêmicos, nas primeiras décadas do século $\mathrm{XX}$, a respeito dos indígenas do Nordeste apontava para a extinção dos mesmos como já consumada. Os primeiros pesquisadores que orientaram seus estudos, na década de 40, para os indígenas do Nordeste - sustentados por uma visão evolucionista, semelhante à concepção ideológica da SPI - buscaram descobrir, nos chamados "remanescentes" dos grupos "extintos", curiosidades folclóricas em rápido desaparecimento que poderiam oferecer uma compreensão da composição do folclore nordestino e, assim, de uma parcela da cultura local. O que passou a constituir como objeto de estudo foi a busca de elementos que os chamados "remanescentes" preservavam da cultura tradicional em meio aos hábitos que, em tese, já haviam sido miscigenados aos costumes da região (cf. Arruti, 1995).

$\mathrm{Na}$ década de 1950, os textos dos pesquisadores permaneceram sem grandes alterações de enfoque e sempre com a preocupação culturalista, ainda com um olhar passadista sobre os indígenas da região. Já na década de 70, embora houvesse trabalhos que operassem com outros recursos lógicos e teóricos que rompiam com os trabalhos 
anteriores, ao abordarem os grupos estudados como realidades contemporâneas, assumiam ainda o ponto-de-vista que aponta para a descaracterização étnica. Nesse caso, os esforços estão voltados para a avaliação do ritmo, do grau e as formas do processo de descaracterização dos grupos indígenas.

Desse modo, dois fatores explicam a denominada "invisibilidade" dos indígenas do Nordeste. Quanto às iniciativas do Estado, este atuou por meio de estratégias de intervenção e com base em teorias predominantes na época a respeito das populações do Nordeste, mas não foi capaz de prever as reviravoltas que tal atuação provocaria. Por outro lado, observamos que todo o trabalho de análise acadêmica da configuração étnica do Nordeste encaminhou-se na mesma direção assumida pela ação estatal, o que demonstrou também a falta de visão dos meios acadêmicos em relação à emergência étnica destes povos.

\section{Os caminhos da emergência étnica}

A gestão da SPI no Nordeste ocorreu no período de 1924 a 1967. Nesse intervalo de tempo, 12 grupos se movimentaram pela aquisição do status legal de indígenas e pela demarcação das terras reservadas, que ocupavam os locais dos antigos aldeamentos.

Foi de autoria do Padre Alfredo Pinto Dâmaso um documento datado de 1931, no qual faz uma defesa da atuação da SPI contra as críticas lançadas pelo jornal $A$ Noite, do Rio de Janeiro, que o acusava de "ser um serviço de catequese leiga que punha Comte no lugar de Cristo, que desperdiçava grande quantidade de dinheiro público inutilmente e que só fazia explorar os silvícolas" (Arruti, 1995, p. 23).

Em seu escrito, o padre prestou um depoimento a respeito do trabalho da SPI e relatou a sua viagem da cidade de Águas Belas, sertão pernambucano, para a então capital federal Rio de Janeiro no ano de 1921, onde procurou o escritório da SPI para conseguir auxílio para os índios denominados na época "carijós". Foi então recebido pela diretoria e funcionários que, segundo ele, embora separados por diversos credos, partilhavam do mesmo ideal: a salvação do índio. O resultado desse contato foi a fundação do posto indígena Dantes Barreto, no extinto aldeamento do Ipanema (cf. Arruti, 1995).

Em decorrência dessa intervenção da SPI, desencadeou-se uma querela judicial entre o estado de Pernambuco e o Ministério da Agricultura, Indústria e Comércio (MAIC), cujo resultado foi o reconhecimento do direito indígena sobre as terras em 
disputa, sem deixar de levar em conta os interesses da cidade que passa a estar contida na área indígena. A solução para o impasse foi o de a cidade passar a pagar arrendamento ao SPI, que se configuraria como tutor dos agora reconhecidos indígenas até a emancipação destes (cf. Arruti, 1995).

Pela lógica indigenista da época, os Fulni- $\hat{o}^{14}$, anteriormente denominados "carijós", foram considerados pela SPI o último grupo a resistir aos ditames civilizatórios no Nordeste. Fato este que chamou a atenção de etnólogos, em especial de Carlos Estevão de Oliveira, diretor do Museu Goeldi na época, que escreveu um artigo a respeito dos Fulni-ô e suas possíveis afiliações lingüísticas, publicado em 1931, e que irá exercer um papel fundamental no processo de emergência dos indígenas da região.

O reconhecimento dos Fulni-ô, no entanto, traz então uma possibilidade e uma oportunidade até então desconhecidas às comunidades localizadas no Nordeste. Elas irão se articular também para serem conhecidas como indígenas, um processo que desembocará na questão das emergências. Tendo como ponto de partida os Fulni-ô, seriam reconhecidos, em sua fase inicial, mais quatro grupos indígenas: os Pankararu, os Xucuru-Kariri, os Kambiwá e os Kariri-Xocó. A partir da mediação destes quatro grupos iniciais, uma rede de emergências será desenvolvida que levará ao reconhecimento de mais outros grupos, em um processo que prossegue até os dias atuais.

Cientes do serviço do Estado que oferecia proteção aos remanescentes indígenas e que estaria entrando em conflito com autoridades locais e proprietários de terras para a demarcação de terras para os indígenas, as lideranças Pankararu, por iniciativa própria, iniciaram uma série de viagens de Brejo dos Padres, local próximo ao Rio São Francisco, para a cidade de Águas Belas a fim de buscar a mediação do Padre Dâmaso para a sua causa. Foi assim que o antropólogo Carlos Estevão estabeleceu seus primeiros contatos com os Pankararu em 1935 e 1937.

Em julho de 1937, Carlos Estevão realizou uma palestra no Instituto Histórico e Geográfico Pernambucano, relatando a descoberta de um "ossuário indígena de real valor científico" numa pequena gruta e o encontro posterior com um grupo de remanescentes indígenas Pankararu em Brejo dos Padres e a descrição de seus costumes, festas, utensílios e o processo de espoliação ao qual eles estiveram

\footnotetext{
${ }^{14}$ Os Fulni-ô se caracterizam por ser a primeira comunidade indígena a ser reconhecida no Nordeste, em razão de ter mantido viva a sua própria língua - o Yathê, assim como um ritual chamado Ouricuri, que se tornou um emblema de sua indianidade. Sua terra se encontra na cidade de Águas Belas, no Pernambuco. Sua população é estimada em 2.788 (ISA, 1989).
} 
submetidos por tão longo tempo. Ao final, um apelo para que amparassem e protegessem, não apenas os habitantes de Brejo dos Padres, mas também os demais remanescentes existentes nos estados do Nordeste.

Segundo Arruti (1995), essa palestra seria um momento catalisador e de inflexão na história dos indígenas do Nordeste, dando início a um processo de revitalização das tradições e invenção cultural que traria desdobramentos até o atual momento.

Em 1940, Carlos Estevão viajou novamente à aldeia de Brejo dos Padres para comunicar aos Pankararu a decisão do SPI de demarcar as suas terras e de lá estabelecer um posto indígena. Os Pankararu, com base em sua memória tradicional, reivindicavam os limites de "légua em quadro" proveniente de uma antiga doação imperial. Athias (2002) sustentou que, de acordo com os relatos indígenas, quatro léguas em quadro de terras foram concedidas pelo imperador Pedro II aos Pankararu, havendo registros e citações diversas em documentos oficiais que confirmam a doação. O ponto central desta concessão de terras era a igreja do aldeamento e a partir dela foram delineadas quatro linhas em cruz, para cada direção, de uma "légua de sesmaria" (6.600 metros), totalizando uma dimensão aproximada de 17.424 hectares (PETI, 1993, p. 38).

No entanto, dois anos depois, o agrônomo responsável pela demarcação chegou à aldeia e, sem respeitar a reivindicação dos Pankararu, reduziu a área do norte, preservando assim a terra de fazendeiros e demarcando a área do sul, terras de pequenos posseiros, o que iniciou uma prolongada disputa judicial e conflitos agrários que prosseguiriam até a década de 1990. Essas disputas por terras lideradas pelos Pankararu contribuíram para caracterizá-los como um dos mais combativos em relação às suas terras e lhes trouxeram ampla visibilidade frente aos outros grupos indígenas, no interior do movimento indigenista e na imprensa.

\section{Os indígenas do Nordeste}

Os indígenas presentes nesta região apresentam determinadas peculiaridades que os diferenciam das outras etnias indígenas presentes no território brasileiro. A própria dificuldade de distinção provém do fato das descontinuidades culturais, que poderiam determinar a unidade e a distinção de um povo indígena da região perante a cultura 
brasileira serem, nesse caso, pouco aparentes. Nesse contexto, os sinais comumente utilizados para determinar os limites de uma cultura para outra - como, no caso, a língua, o vestuário, a semelhança de traços físicos, diferentes rituais - não possuem aplicação. Nas regiões de colonização antiga, como é o caso do Nordeste, verificou-se a ocorrência de casamentos entre indígenas de diferentes etnias e, também, com nãoindígenas, que eram moradores de quilombos, fazendas e aldeamentos. As trocas culturais ocorreram no decorrer de gerações e alcançaram um estado de acomodação nas crenças e costumes (cf. Oliveira Filho, 1996).

Um fato determinante para a compreensão da questão acima apresentada é o do surgimento de novas identidades indígenas, processo denominado de etnogênese, segundo Oliveira Filho (1996), que utiliza os postulados de Barth e Bourdieu para esclarecer esse fenômeno histórico. De acordo com Barth (2000), um grupo étnico não é definido por seu estofo cultural (que se transforma com o decorrer do tempo e também é influenciado por ajustamentos ecológicos) ou como uma unidade portadora de cultura, mas sim como um "tipo organizacional" que se vale de critérios de pertencimento e exclusão para estabelecer suas fronteiras e a busca de normatização da interação entre os membros internos e os que são de fora, onde se tornam importantes a auto-atribuição e a atribuição pelos outros. Desse modo, o código essencial da identidade que estabelece as relações interétnicas se exprime por contraste. Desse modo, "as identidades étnicas não possuem uma substância (como se pensou que era a cultura), mas são construídas nas relações de contraste" (Vaz Filho, 2006, p. 4).

Seguindo na mesma linha teórica de Barth, Cardoso de Oliveira (2003) trabalha com a noção de identidade contrastiva:

A identidade contrastiva parece se constituir na essência da identidade étnica (...). Implica a afirmação do nós diante dos outros. Quando uma pessoa ou um grupo se afirmam como tais, o fazem como meio de diferenciação em relação a alguma pessoa ou grupo com que se defrontam. É uma identidade que surge por oposição. Ela não se afirma isoladamente. No caso da identidade étnica ela se afirma 'negando' a outra identidade, 'etnocentricamente' por ela visualizada (Cardoso de Oliveira, 2003, p. 120).

Desse modo, a identidade étnica não se estabelece de forma absoluta, mas sim dentro de um sistema de identidades étnicas ou em uma situação de contato interétnico, 
sobretudo quando esta ocorre como fricção interétnica. Fricção interétnica é o termo utilizado por Cardoso de Oliveira (2003) para descrever uma situação de contato entre grupos étnicos que estejam irreversivelmente vinculados uns aos outros, mesmo que estes vínculos estejam permeados por contradições que são expressas ora por conflitos (manifestos) ora por tensões (latentes). No caso da relação entre os indígenas e os brancos, observamos que a fricção interétnica ocorre como relações de dominação e sujeição. Nessas relações, o que invariavelmente ocorre é que ou os indígenas ou grupos indígenas reafirmam a sua identidade étnica ou sucumbem, acabando por negar a si próprios. Desse modo, o conceito de identidade contrastiva se torna importante para compreender os mecanismos de identificação que acabam por se tornar manipuláveis por pessoas, grupos ou instituições por meio do uso e desuso dos diversos etnônimos no jogo ideológico das classificações étnico-raciais (cf. Silva, 2005). Também cabe lembrar que esta noção, muito presente na literatura antropológica, tem orientado as legislações mais recentes a respeito dos povos nativos, como a Convenção $\mathrm{n}^{\circ} 169$ da OIT. No entanto, de acordo com Silva (2005) não se pode transformar esta noção em uma essência e cristalizar a identidade étnica como objeto de análise estanque, pois acaba por promover uma polaridade analítica para a realidade vivenciada pelas sociedades indígenas brasileiras, estabelecendo os "índios" de um lado e os "brancos" ou "não-índios" do outro, desconsiderando outras categorias sociais, como o dos "índios misturados".

Conforme Vaz Filho (2006), não importa se a distinção se manifesta em traços culturais, mas que o grupo étnico se reconheça como distinto culturalmente. Por outro lado, Novaes (1993) considera pouco produtivo o esvaziamento das dimensões culturais da análise das situações de contato. "Pois é no campo da cultura e nas relações entre o poder e a cultura que as sociedades indígenas conseguem articular seus processos de resistência à sociedade envolvente" (Novaes, 1993, p. 46).

\section{Uma acepção moderna de cultura e a etnicidade Pankararu}

De acordo com Bourdieu (1984), a homogeneidade cultural resulta muito mais de um processo de criação coletiva e de constituição de um significado coletivo do que de fatores determinantes a que usualmente se recorre para a identificação de um grupo étnico. Pode-se afirmar então que o ato de partilhar uma determinada cultura é o 
resultado muito mais da organização de um grupo étnico. As discussões a respeito da etnicidade nos levaram a centrar a visão sobre as fronteiras que delimitam uma cultura. De acordo com essa concepção, a definição de cultura não adviria de seus traços constitutivos e sim do estabelecimento de fronteiras entre um grupo social e outro, o que é realizado sob a ótica da diferença. Nesse sentido, a cultura não é concebida como algo que mantém uma suposta integridade, mas como algo que preserva a sua diferenciação em relação às outras. Sendo assim, as culturas passam a ser percebidas em suas transformações e não em sua suposta integridade. Todas as culturas estão presentes na história, o que as diferencia é o modo como tratam a história da civilização com que se defrontam e como se transformam (cf. Cohn, 2001).

Segundo Oliveira Filho (2000), uma visão que deve ser reavaliada é a recomendação dada aos antropólogos e etno-historiadores de que, para se conhecer a singularidade de uma cultura indígena, é necessário buscar os elementos de sua cultura de origem, que não estejam contaminados pela presença de instituições coloniais. Segundo Oliveira Filho:

\begin{abstract}
A expansão colonial produziu um quadro político e ideológico para a consolidação de uma disciplina que focalizava especificamente o pensamento e a existência dos povos indígenas como 'nossos contemporâneos primitivos'. E, por mais paradoxal que isso fosse, as culturas nativas eram exaustivamente descritas pelos antropólogos (...) como sistemas fechados e coerentes, quase inteiramente virgens de influência cultural do Ocidente. Menos que observadas na plenitude de sua operação, as culturas nativas foram idealmente reconstituídas, o pesquisador praticando um esforço de abstração para imaginar como tudo se passaria caso os brancos (ele incluindo) ali não estivessem (Oliveira Filho, 2000, p. 23).
\end{abstract}

Dentro do contexto das "sociedades complexas", há uma acepção mais atual do termo cultura, que passa a ser visto como "todo um conjunto de símbolos que permite a comunicação entre os homens e implica o estabelecimento de obrigações recíprocas e convergência em termos de crenças e valores" (Oliveira, 2000, p. 22). O citado conjunto de símbolos apresenta, em termos de abrangência, os mais variados níveis, seja em contextos transnacionais (religiões universais ou ideologias políticas), contextos intersocietários (a diplomacia) ou em escala infra-societária (culturas peculiares de etnias). Desse modo, podemos perceber que uma sociedade mantém relações umas com 
as outras, podendo ser elas de justaposição ou de integração, mas também de exclusão e de conflitos, ou, ainda, marcadas por indiferença ou mesmo por conexões menores.

Outro ponto a ser destacado é que as culturas não estão em um nível de inteira co-extensão com as sociedades nacionais. Estudos teóricos a respeito da cultura sugerem que sejam deixadas de lado as definições de cultura configuradas como sistemas fechados e que, no lugar delas, os conceitos sejam trabalhados com base em processos de circulação de significados. Nesse sentido, Oliveira parte dos estudos de Fredrik Barth (2000) e Ulf Hannerz (1997) a respeito da cultura:

\begin{abstract}
Barth serve-se da metáfora de corrente (streams) - que não mantém uma forma regular e definida, mas que, em algum lugar, possui um centro dotado de força e aderência para arrastar ou envolver outros artefatos, tal capacidade diluindo-se em suas extremidades. Para iniciar a circulação das tradições culturais dentro ou através de diferentes unidades sociais, Hannerz (1997) utiliza-se da noção de fluxos culturais (cultural flows) para enfatizar o caráter não-estrutural, dinâmico e virtual e constitutivo da cultura (Oliveira, 2000, pp. 22-23).
\end{abstract}

De acordo com Oliveira (2000), um construto teórico com base nesses pressupostos demonstra ser mais produtivo e alcança maior universalidade, uma vez que permite uma maior amplitude de comparações. Desse modo, não podemos considerar a cultura como um todo compartilhado, mas sim devemos levar em conta que o que é transmitido pelas gerações não é constituído de totalidades. A tradição não é um corpus fechado que persiste no tempo. A transmissão da cultura e das tradições, ao contrário, convive com a mudança (cf. Cohn, 2001).

Pensando no contexto brasileiro, seria um grande equívoco tratar as culturas indígenas como se fossem homogêneas e fechadas em si mesmas, sendo apenas diferenciadas por sua entrada no cenário histórico. Uma das conseqüências desse equívoco ocorre quando essa concepção naturalizada de cultura se encaixa com exatidão na representação do senso comum sobre os índios, que é a de um indivíduo que habita na selva, utiliza técnicas rudimentares e possui instituições mais primitivas, sendo ele pouco distanciado da natureza. É, no entanto, essa representação que habita o imaginário das manifestações artísticas, os estatutos legais, a política indigenista e mesmo os mecanismos oficiais de proteção e assistência aos índios. 
Ao ser acionada muitas vezes como instrumento de defesa dos indígenas, tal representação torna-se um argumento para se propor, na avaliação de uma determinada cultura, "prudência e suspeição quanto à sua pureza e autenticidade, justificando também os debates sobre o grau de mudança cultural que ainda seria razoável admitir naqueles que fossem reconhecidos como indígenas" (Oliveira, 2000, p. 23).

Monta-se, assim, um quadro de suspeição em relação a uma suposta manipulação falseadora, seja ela realizada pelos interessados (indígenas) ou pelos que defendem os seus interesses (antropólogos, missionários e órgãos indigenistas). O discurso proveniente desse contexto de suspeição repousa na concepção do senso comum - antiga, superada e, no entanto, ainda bastante arraigada nos discursos atuais do índio como um indivíduo "primitivo". Desse modo, torna-se possível, então, questionar a existência de "índios" no Nordeste (uma vez que a historiografia oficial os qualificava como "integrados") ou mesmo nas grandes cidades, visto o êxodo de muitos deles das terras indígenas, em decorrência dos conflitos de terra e das pouquíssimas chances, ou mesmo nenhuma, de subsistência. "Institui-se, então, implicitamente uma polaridade entre as culturas indígenas 'intocadas' (seriam as autênticas) e aquelas afetadas por 'processos de aculturação' (estas já seriam inautênticas, pois contêm elementos exógenos e espúrios)" (Oliveira, 2000, p. 23). De acordo com o conceito de aculturação ${ }^{15}$, a cultura é considerada como estática e passível de sofrer um processo de extinção, desconstrução e descaracterização em virtude da influência dominadora de um grupo social sobre outro grupo. Ela não leva em conta a capacidade de uma cultura de incorporar novos elementos e se ressignificar. Considerando o caso dos indígenas do Nordeste, podemos sustentar que o conceito de aculturação deve ser amplamente questionado e criticado, pelo fato de manter uma noção irreal, que é a das "culturas indígenas intocadas", o que o faz ser impreciso, ineficaz e incapaz de tratar de questões mais complexas.

Outro questionamento a ser colocado é o da representação do índio como indivíduo "primitivo". No caso da possibilidade da constituição de uma cultura, é necessário que se parta dos pensamentos, ações e sentimentos de seus portadores atuais. Para isso, tratando-se dos indígenas, deve-se tomar em consideração, antes de tudo, o patrimônio simbólico dos índios atuais, não havendo, portanto, razões para se iniciar

\footnotetext{
${ }^{15} \mathrm{O}$ conceito de aculturação na antropologia moderna, herdado das teorias culturalistas norte-americanas, considera a cultura como sendo estática e afirma que as influências de um grupo social sobre outro poderia ocasionar um processo de perda irreversível dos elementos culturais e a desconstrução da identidade de um grupo étnico.
} 
qualquer discurso a respeito da autenticidade, nem mesmo estabelecer quaisquer parâmetros exteriores e arbitrários para se definir o que é uma cultura indígena específica.

É necessário compreender que um patrimônio cultural não pode ser caracterizado como um bloco monolítico, mas sim formado por diferentes tradições culturais. É o caso da chamada cultura "brasileira". Para que sejam considerados elementos integrantes de uma cultura, os costumes e as crenças não precisam ser concebidos como itens exclusivos de uma determinada sociedade, podendo ser compartilhados por outros povos, assim como não necessitam ser antigos, sendo a adaptação destes ao contexto moderno e globalizado um fato comum.

A incorporação de rituais, crenças e práticas exógenas não necessariamente significa que aquela cultura não seja 'autenticamente indígena' ou pertencesse a 'índios aculturados' (no sentido pejorativo de ex-índios ou falsos índios). Operadores externos podem ser ressemantizados e, assim, virem a ser fundamentais para a preservação ou adaptação de uma organização social e de um modo de vida indígena (Oliveira, 2000, p. 24).

\section{A invenção das tradições}

Lénclud (2005) aponta para a necessidade de se proceder a desconstrução do sentido usual da tradição. A noção de tradição está associada, entre outras idéias, a da conservação no tempo. A pergunta que se coloca é: a conservação no tempo é um critério de tradicionalidade? A idéia que está por trás dessa concepção é a de que um objeto cultural pode ser considerado tradicional pelo fato de repetir um modelo de origem elaborado em uma época razoavelmente distante. A tradição implicaria, paradoxalmente, a ausência de mudança em um contexto de mudança. A grande questão que surge a respeito desse tipo de concepção é a de que se existem meios de verificar se realmente são idênticos a um modelo de origem que não mais existe e que, portanto, não poderia ser diretamente observado. Além disso, em relação à cultura, não existe tabula rasa. Qualquer mudança, por mais revolucionária que possa parecer, ocorre sob a égide de uma continuidade e toda permanência é constituída por variações. Todos os objetos culturais qualificados de tradicionais sofrem mudanças e isso é facilmente verificável pelo fato de comprovarmos que a narração de um mito ou um conto varia de um 
indivíduo a outro, porque neles foram omitidos certos elementos ou foram acrescentados outros. É o que também se pode dizer a respeito dos rituais, que não se desenvolvem de maneira idêntica. O princípio de substituição no "pensamento selvagem" foi amplamente comprovado por Lévi-Strauss. Na falta de um determinado elemento em um ritual, por exemplo, o indígena o substituiria sem hesitar por outro, não se manifestando nele o sentimento de não-cumprimento da tradição. Enfim, a tradição apresenta uma disposição singular à variação, além de oferecer uma surpreendente margem de liberdade aos que dela servem (cf. Lénclud, 2005, s/p).

Então, no que consistiria a tradição? Não seria uma obra de outra era que os contemporâneos receberiam passivamente, mas, de acordo com os termos de Pouillon, "um ponto de vista" a partir do qual os homens do presente desenvolvem o sentimento de respeito ao que o precedeu, isto é, uma interpretação do passado conduzida em função de critérios rigorosamente contemporâneos. "Não se trata de transplantar o presente sobre o passado, mas de descobrir neste o esboço de soluções que cremos justas hoje não porque ele tenha sido pensado ontem, mas porque nós o pensamos agora" (Pouillon, 1975, p. 160 Apud Lénclud, 2005, s/p). Quer dizer, não é o passado que produz o presente, mas é o presente que dá forma ao seu passado.

Como prossegue Pouillon, "o passado impõe apenas os limites dentro dos quais nossas interpretações ficam a depender apenas do nosso presente" (Pouillon, 1975, p. 160 Apud Lénclud, 2005, s/p), o que implica que esses limites são singularmente fluidos, isto é, a margem de manobra que o passado oferece não reconhece praticamente limites. A força da tradição não se mede em relação à exatidão no exercício da reconstituição histórica. A sua verdade não é, para retomar uma distinção clássica, marcada pela idéia de correspondência (adaequatio), mas pela de coerência. É, de certa maneira, da tradição como um testemunho: uma retórica do que supostamente teria sido. A tradição se refere às suas referências, à sua herança, mas, ao contrário das heranças políticas, sempre sofridas e vilipendiadas, uma herança constituída bastante livremente, como se viu, e geralmente glorificada.

Uma concepção interessante para essa discussão é trazida por Eric Hobsbawm, em A invenção das tradições (1984), uma introdução do livro de mesmo nome. Hobsbawm (1984) observa que, em muitas vezes, as tradições que parecem antigas, ou que até mesmo assim consideradas, são bastante recentes e foram até mesmo inventadas. Nesse sentido, o historiador traz o termo "tradição inventada", que é utilizado em um sentido amplo, incluindo tanto as tradições que surgiram e se 
estabeleceram de forma rápida, embora não seja possível estabelecer com clareza o período no qual surgiram (podendo ser bastante recentes), mas também as que foram realmente inventadas, formadas e institucionalizadas formalmente. $O$ termo é compreendido como um:

(...) conjunto de práticas normalmente reguladas por regras tácita ou abertamente aceitas; tais práticas, de natureza ritual e simbólica, visam inculcar certos valores e normas de comportamento através da repetição, o que implica, automaticamente, uma continuidade em relação ao passado. Aliás, sempre que possível, tenta-se estabelecer continuidade com um passado histórico apropriado (...). O passado histórico no qual a nova tradição é inserida não precisa ser remoto, perdido nas brumas do tempo (Hobsbawm, 1984, pp. 9-10).

No entanto, a referência a esse passado histórico é estabelecida, por parte dessas tradições, por meio de uma continuidade artificial: assumem a forma de referência a situações anteriores ou se formam como reações a situações novas, ou fixam, por meio da repetição praticamente obrigatória, o seu próprio passado. Para Hobsbawm (1984), o que desperta o interesse dos historiadores a respeito da temática da 'invenção da tradição' é o contraste estabelecido entre as transformações constantes e inovações do mundo moderno e a busca por se estruturar ao menos alguns aspectos da vida social de maneira imutável e invariável. Observa ainda um elemento importante: o uso de elementos antigos na invenção de novas tradições para finalidades bem originais. Podemos encontrar no passado de qualquer sociedade um amplo repertório de elementos antigos e também uma linguagem elaborada, formada por práticas e comunicações simbólicas. Para Hobsbawm:

Às vezes, as novas tradições podiam ser prontamente enxertadas nas velhas; outras vezes, podiam ser inventadas com empréstimos fornecidos pelos depósitos bem supridos do ritual, simbolismo e princípios morais oficiais - religião e pompa principesca, folclore e maçonaria (...) (Hobsbawm, 1984. p. 14).

\section{A mobilização étnica Pankararu}

Todos esses postulados teóricos auxiliam a compreender os mecanismos de reconstrução de identidade étnica engendrados pelos indígenas no interior do processo 
de democratização da sociedade brasileira. Conforme Mauro (2007), iniciativas dos povos indígenas têm feito com que determinados elementos da cultura e religião tradicionais possuam grande importância política na delimitação da fronteira étnica do grupo, sendo acionados em todas as ocasiões que são necessárias lutas e reivindicações do grupo por seus direitos. A construção de uma identidade étnica retira das "tradições inventadas" elementos culturais que, embora deixem de ser idênticos ao que eram, são utilizados com uma conotação política.

De acordo com Cunha:

A cultura original de um grupo étnico, na diáspora ou em situações de intenso contato, não se perde ou se funde simplesmente, mas adquire uma nova função, essencial e que acresce às outras, enquanto que se torna cultura de contraste: este novo princípio que a subtende, a do contraste, determina vários processos. A cultura tende ao mesmo tempo a se acentuar, tornando-se mais visível, e a se simplificar e enrijecer, reduzindo-se a um número menor de traços que se tornam diacríticos (Cunha, 1987, p. 99).

Ainda de acordo com Cunha (1987), a escolha dos tipos de traços culturais que garantirão a distintividade de um grupo étnico depende dos grupos e da sociedade envolvente com os quais ele irá interagir, uma vez que os sinais diacríticos deveriam ser capazes de se opor a outros de mesmo tipo. Para Arruti (2002), torna-se inevitável fazer referência à cultura nos processos de constituição de uma identificação étnica. Isso porque a cultura deixou de ser uma mera categoria analítica para os estudos antropológicos, mas também se tornou objeto de reflexão e monitoramento do próprio grupo étnico a respeito de si próprio e sobre as expectativas dos "outros".

Uma cultura que está fora do discurso antropológico, sob a posse do próprio grupo, moldada pelos próprios atores que, muitas vezes, estão informados sobre os usos antropológicos (ou para-antropológicos) atribuídos a ela (Arruti, 2002, p. 25).

Desse modo, a cultura torna-se objeto da própria ação política, que agora pode ser definida como a decisão estratégica sobre os usos da cultura. É nesse sentido que podemos discutir o conceito de "indianidade". 
Segundo Oliveira (1988), o termo "indianidade" é concebido no sentido de uma forma de concepção dos indivíduos formulada nas relações de interação destes com os órgãos tutelares ou aparelhos de Estado a partir de uma determinada imagem do que deve ser um "índio". Isso acaba por impor aos diversos grupos sociais (e culturas) um modelo, que acaba por se assumir efetivamente por estes grupos. Nesse caso, a articulação é feita no sentido de recuperar ou construir signos de identidade indígena reconhecidos pela sociedade nacional. As populações percebem a expectativa da população brasileira do que é o índio e se apropriam desse estereótipo, pintando-se, fazendo cocares para si e utilizando tangas. No caso dos indígenas Pankararu, na mesma linha de definição deste mesmo termo por Grunewald (1995), a indianidade pode ainda ser visualizada como uma alternativa política de acesso a determinados recursos como o próprio território indígena e outros recursos assistenciais.

Segundo Oliveira Filho (1996), dois fatores propiciaram essa recuperação étnica. Por um lado, foram processos políticos e econômicos que impulsionaram o aumento de pressão sobre a terra, uma vez que proprietários agiram para a expulsão dos "moradores", rompendo, desse modo, uma aliança que haviam estabelecido entre grupos e famílias isoladas. Por outro lado, observamos que, para alguns setores ameaçados do campesinato, surgiu uma alternativa étnica possível, proporcionada pela implementação do SPI na região e de um novo campo indigenista constituído no final da década de 1980, com a atuação da FUNAI, da Cimi e de outras entidades nãogovernamentais.

Sendo assim, o que se nota é que a descontinuidade que marca as origens dos povos indígenas do Nordeste é uma questão de instância política fundamentada em fatores históricos. Isso explica o fato da origem destes povos remontar a processos históricos concretos, como o aldeamento e a territorialização por missões religiosas. Mesmo o surgimento mítico do grupo étnico é associado a líderes históricos que promoveram a "refundação" da aldeia e o resgate do verdadeiro nome do povo, que passa a ser adotado então como etnônimo ${ }^{16}$ (cf. Oliveira Filho, 1996).

Uma identidade indígena proveniente de uma ruptura política se constitui, de forma geral, por meio da religião. É por meio dela que ocorre a importação, reprodução e adaptação das manifestações culturais, que proporcionam aos povos a condição indígena e estabelecem as fronteiras étnicas. Como afirma Novaes:

\footnotetext{
${ }^{16}$ Etnônimo, segundo o Dicionário Aurélio, seria o nome de comunidades políticas ou religiosas, quando a designação destas passa a ser tomada em sentido étnico.
} 
A identidade é evocada sempre que um grupo reivindica, para si, o espaço político da diferença. Nessas manifestações não há um interlocutor específico. São grupos que se dirigem à sociedade, de modo geral, ou a uma entidade tão abstrata como 'o governo'. É nesse contexto amplo, de reconhecimento de semelhanças e diferenças, que se pode perceber a articulação entre poder e cultura, entre a vontade de resgate da autonomia e os caminhos para se chegar até ela, que passam, necessariamente pelas trilhas da cultura, pois é exatamente no domínio da cultura que estes grupos (...) resgatam sua autonomia e reafirmar a sua diferença (Novaes, 1993, p. 27).

De certo modo, os indígenas Pankararu se utilizaram justamente do recurso da invenção das tradições para engendrar uma identidade étnica e assim iniciar a luta pelos seus direitos à terra e também a um espaço diante de uma sociedade que se silenciou a respeito de suas condições de vida e de sua história. A tradição cultural do Toré é um elemento de grande importância, não somente para os Pankararu, mas também para os demais indígenas do Nordeste, em sua luta por melhores condições de subsistência diante do quadro nacional e que não pode ser menosprezado.

\section{O ritual do Toré: elemento constitutivo da identidade Pankararu}

Entre os emblemas culturais que ainda subsistem entre os Pankararu, o principal é o sistema ritual do Toré e o culto aos Encantados associado a ele. Tanto na Aldeia do Brejo dos Padres quanto em São Paulo, o ritual é um elemento constituinte e unificador dos Pankararu. 


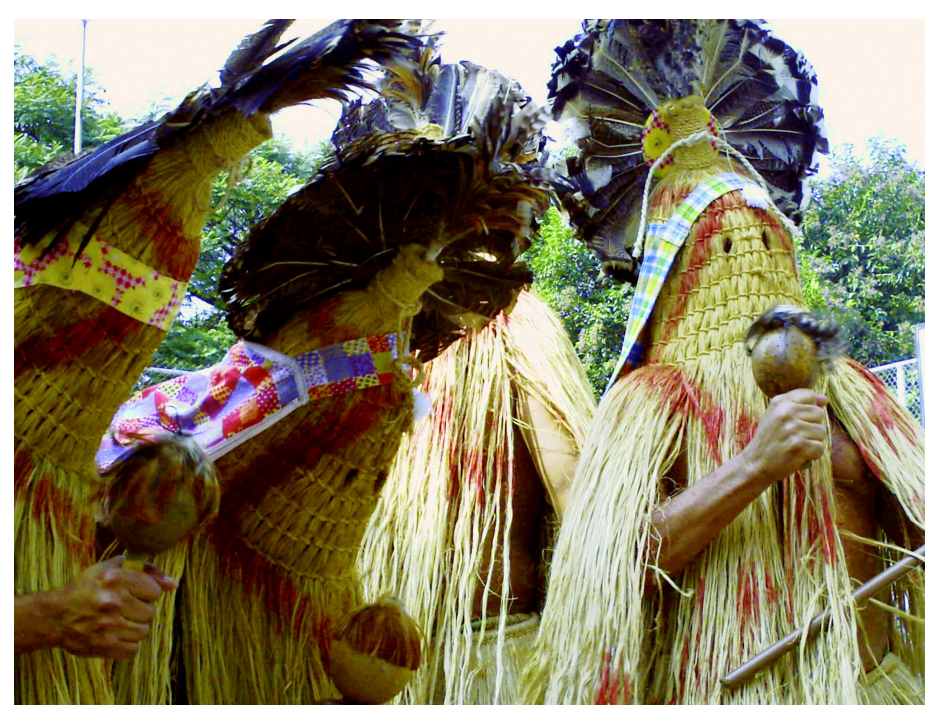

De acordo com Cunha (2007), a definição mais usual de Toré é a de uma manifestação de dança, muito comum entre os grupos indígenas do Nordeste. Os termos se alteram de acordo com os grupos, sendo Toré entre os Pankararu e outros grupos; Torém entre os Tremembé (Oliveira, 1997); Tolê entre os Fulni-ô (Nascimento, 1998) ou Tule, Ture ou Tore entre os Wayãpi (Beaudet, 1997). O Toré carrega um sentido muito mais amplo do que uma dança ou um instrumento, podendo ser também uma modalidade musical, um cerimonial, assim como um ato público, dependendo do contexto no qual é realizado (cf. Cunha, 2007). De qualquer modo, devemos ressaltar que o conceito de Toré está e esteve intimamente ligado ao critério de identificação de grupos indígenas emergentes utilizado pelos órgãos indigenistas (SPI e FUNAI). Ao contrário dos diferentes grupos indígenas presentes no Brasil Central e na Amazônia, foram os grupos indígenas do Nordeste que foram em busca dos órgãos indigenistas, na procura por reconhecimento de seus direitos sobre as terras que ocupavam. Devido a todo um histórico de conflitos, perseguições e aldeamentos forçados e um longo processo de readaptação às novas condições sociais, tornara-se difícil encontrar entre os grupos "remanescentes" um sinal de indianidade típica, como requerida pelos órgãos governamentais, tornando-se, portanto, o Toré um critério fundamental para a afirmação de uma identidade étnica indígena.

O Toré, ou "brincadeira de índio" como os Pankararu mesmo definem, é realizado nas mais diversas situações, em locais públicos e privados e nas mais diversas festividades religiosas e profanas. De acordo com Oliveira Filho (2005), o Toré, presente na maioria das coletividades indígenas do Nordeste, é um fenômeno complexo, podendo ser uma atividade tanto lúdica como organizadora, tanto íntima como 
emblemática. É nela que as coletividades se materializam, tanto na transmissão como na reafirmação de valores e conhecimentos.

É como performance política, no entanto, que o Toré se realiza como afirmadora da identidade indígena, sem que perca a sua condição de atividade lúdica e sua conexão com as aspirações individuais. Ele atua como movimento tanto de atualização de memória como também de criação, com base na seleção dessa mesma memória como forma de resgatar suas tradições no contexto da contemporaneidade.

Como um caleidoscópio, o Toré reordena e elabora saberes múltiplos sobre a natureza, o tempo e o imaginário social, celebrando a vida, a criação permanente e afirmando a possibilidade futura de uma comunidade benfazeja entre todos que dele participam (Oliveira Filho, 2005, p. 10).

Segundo Arruti (2005), para uma melhor compreensão do ritual, é de fundamental importância compreender o que são os Encantados e o que são as “sementes". Os Encantados, figuras centrais da cosmologia Pankararu, são, de acordo com a concepção dos mesmos, "vivos que se encantaram" de forma voluntária ou involuntária, o que nos impossibilita descrevermos qualquer culto a eles como "culto aos mortos". Esse "encantamento", que é tratado como um segredo a ser guardado ou como um mistério pelos próprios Pankararu, constitui a parte central da identidade da aldeia, de modo que cada povo possui seu panteão de Encantados, mas que podem ser partilhados durante certo tempo por grupos ligados entre si, "como pontas da rama de um mesmo tronco", segundo uma imagem metafórica que eles mesmos utilizam.

Atribui-se às serras que demarcam as cercanias do Brejo dos Padres como a atual habitação dos Encantados Pankararu, sendo que cada formação rochosa corresponde a um Encantado. No entanto, há uma relação especial dos Encantados com as cachoeiras de Paulo Afonso e Itaparica, hoje extintas em razão da construção de barragens na região. Narrativas dos antigos Pankararu contam sobre o surgimento dos Encantados, e dos próprios Pankararu, em razão do "encantamento" de toda uma população de indígenas que teria se lançado na cachoeira de Paulo Afonso. Seriam esses os Encantados que passaram a habitar a cachoeira e que se comunicariam com os indígenas por meio do estrondo das águas, predizendo as desgraças, mortes ou mesmo novos encantamentos. 
Seja como locais de trânsito entre os diversos grupos indígenas ou como espaços fundamentais para a cosmologia Pankararu, as cachoeiras de Paulo Afonso e Itaparica eram consideradas vitais para as comunidades indígenas, principalmente para os Pankararu. Essas cachoeiras foram sucessivamente tragadas em virtude da construção de barragens, o que promoveu o bloqueio do intercâmbio entre as comunidades indígenas; além do fato importantíssimo de ser a morada dos Encantados e, portanto, portadores de vínculo afetivo e mítico. Sua interrupção limitou o panteão dos Encantados, assim como o universo dos que ainda iriam se manifestar. Uma vez que as cachoeiras não mais existem, a comunicação entre os Pankararu e os Encantados se realiza apenas por meio dos "sonhos". Segundo a concepção deles, todo esse processo continua, pois outros índios, depois de anunciados e devidamente preparados, podem continuar se encantando.

Já a "semente" é a forma material pela qual os Encantados se manifestaram pela primeira vez aos Pankararu, sendo considerada como uma espécie de "transporte". Uma vez escolhido um “zelador”, ou seja, alguém que irá zelar pelos Encantados, eles próprios surgem a esse indivíduo em sonho, anunciando que ele receberá sua "semente". Essa semente corresponde a apenas um Encantado. Uma vez que se manifestaram, os Encantados podem ser cultuados em cerimônias domésticas e particulares, nas quais os Pankararu fumam, tomam garapa e cantam o "toante" do Encantado, mas sem que haja dança. É só quando o Encantado solicita que seja "levantado", que ele pode ser cultuado também no Toré, que é a versão pública e coletiva deste culto.

Retomando o modo como o ritual do Toré se realiza, é preciso ver que se trata de uma dança coletiva que pode abranger um número indefinido de participantes. Estes podem se apresentar em parte pintados de branco e em parte com máscaras. O ritmo da dança é proporcionado pelo "toante", uma música de forte compasso entoada por um “cantador" e que é respondida por gritos uníssonos e periódicos pelos "dançadores". A máscara e as saias, feitas com fibras de uma planta (ouricuri ou croá), e o próprio dançador, incorporado por um Encantado, formam um conjunto denominado Praiá. Um conjunto de Praiás forma uma espécie de "batalhão", que se torna integrante de um mesmo "terreiro" e fica sob os cuidados de um "zelador". Cada Praiá seria correspondente então de um Encantado do panteão daquele terreiro e a soma destes forma o panteão da "aldeia". O Toré provavelmente era apenas uma parte recorrente em outros rituais e que se tornou autônomo com o decorrer do tempo. No entanto, foi o 
elemento cultural mais identificável que assumiu o lugar de um emblema, primeiro para o indigenismo, depois, para os próprios grupos indígenas, tornando-se assim, símbolo de indianidade (cf. Arruti, 2005).

O ritual se inicia após a escolha, por parte dos Encantados, de um "zelador" que irá receber a "semente". "Levantar é tecer" é uma expressão utilizada para se referir ao momento em que o escolhido será incumbido de levantar o Praiá, ou seja, tecer a indumentária (o Praiá) para o ritual. Mas esta ação que não pode ser muito longa, pois a responsabilidade que pesa sobre um "zelador" no ritual do Toré é grande, podendo ele próprio sofrer castigos por parte dos próprios Encantados. Cabe aos "zeladores" o papel de orientação, mas também de conservação da tradição, seja por meio dos cuidados em relação às roupas dos Praiás ou com a "semente" que lhe fora confiada, seja por meio da ligação permanente que terá com os Encantados. Ele deve confeccionar ou providenciar a confecção do Praiá, que serve para encobrir a personalidade do dançador, sendo que este se torna, no ritual, a materialização do próprio Encantado. Como podemos observar, o zelador é, para os Pankararu, o responsável pela transmissão da tradição, assumindo, portanto, um papel relevante no que diz respeito ao vínculo destes povos com suas origens e mitos.

\section{O ensino do Toré}

O ensino do Toré não se resume a uma aula de coreografia. Ensinar o toré tem o significado de proporcionar a "semente" da aldeia ou "ensinar o caminho aos Encantados", uma vez que este tinha sido esquecido em função do processo de "mistura" e da proibição dos rituais. A distinção entre os grupos do "tronco velho" e as "pontas de rama" se dá pela relação com o sobrenatural que o primeiro grupo teria, ou seja, uma relação de conhecimento e consolidação das formas de acesso aos ancestrais, o que configuraria a "força" de um grupo. "Ensinar o Toré não é transmitir essa força de forma direta, mas proporcionar a semente para o desenvolvimento de um novo tronco que havia sido cortado de sua base" (Arruti, 1995, p. 42).

Uma vez recebida a semente e os caminhos para os Encantados, o grupo "ponta de rama" precisa prosseguir sozinho, de modo a constituir a sua própria relação com os Encantados e os Praiás, o seu próprio Toré e seus toantes, com suas características singulares. É a configuração de um caminho próprio que proporcionará a este grupo uma característica identitária e étnica única, diversa em relação ao seu tronco e também 
em relação aos outros grupos que receberam a "semente" e os "caminhos". É por meio do desenvolvimento de sua religião, com base no Toré e o contato com os Encantados, é que o grupo assume o estatuto de indígena, não mais de caboclo ou índio indistinto. "Ensinar o toré e levantar uma aldeia são assim, simultaneamente, atos políticos, coletivos, de invenção cultural e projeção do futuro, tanto quanto atos místicos, particularizantes, de retomada do passado" (Arruti, 1995, p. 43).

Quando um "tronco velho" ensina o Toré para um grupo emergente, ocorre um jogo de duplos em várias instâncias: ensina-se o caminho aos Encantados, mas também o caminho para os "direitos" a serem adquiridos pelo status de indígena; transmite-se uma mensagem ao grupo receptor, mas também ao próprio órgão indigenista; é proporcionado o acesso ao sobrenatural, mas também ao "governo"; os benefícios proporcionados pela mensagem transmitida são de via dupla, pois o grupo que emite a mensagem também fortalece a sua posição e autoridade diante dos grupos emergentes e os órgãos que lidam com as questões indígenas.

Desse modo, verificamos que a transmissão de Toré é um evento complexo de comunicação, no qual os vários emissores e receptores e as diversas mensagens interagem de modo simultâneo e cuja apreensão depende dos diferentes contextos que são estabelecidos, tanto em sua enunciação como em sua análise. Nessas situações, o que está em evidência é o próprio código de comunicação, uma vez que são os procedimentos de interlocução e uma determinada linguagem que estão sendo tematizados e apreendidos.

\section{A música Pankararu}

Segundo Cunha (1999), a música Pankararu possui fundamental importância na organização política e sócio-cultural dos Pankararu, além de ser um elemento de grande importância na transmissão e manutenção dos elementos culturais e de preservação da identidade étnica do grupo. O repertório musical Pankararu é um código que facilita o acesso e estabelece um canal de comunicação com o mundo sobrenatural, possuindo uma estreita relação com a crença religiosa nos Encantados, pois é por meio dela que os Pankararu passam a entrar em contato com esses espíritos protetores.

Mas a influência dos Encantados não se restringe apenas à religiosidade do grupo. Ela está presente na organização política do grupo e influencia todo o sistema social da vida dos Pankararu. Neste sentido, a música também serve como veículo para 
a descoberta de novos e importantes aspectos da vida social do grupo, aspecto que iremos explorar durante o texto.

A música Pankararu está dividida da seguinte forma: músicas de gaita e de rabo de tatu (modalidades instrumentais), toantes e torés ${ }^{17}$ (modalidades vocais). Na maioria das vezes, a música de gaita é a versão instrumental dos toantes e torés ou de momentos específicos de cada rito.

De acordo com Cunha (2007), a maioria dos Pankararu afirma que a música é passada para os cantadores por meio dos Encantados. Os toantes e torés são revelados pelos respectivos Encantados em sonhos aos denominados “zeladores". Desse modo, cada Encantado possui um toante ou um toré, sendo reconhecido pelos Pankararu quando é entoado. Eles ensinam as músicas por meio de sonhos e se encarregam de escolher os futuros cantadores e cantadeiras. Quando um Encantado se apresenta a um zelador, ele irá também ensinar seus toantes e seus torés.

É pelo fato de invocarem os Encantados nas festas e rituais que os cantadores e cantadeiras adquirem o respeito na comunidade, passando a conquistar prestígio e altas posições dentro da sociedade Pankararu.

Nos toantes e torés, o cantador ou a cantadora marca o ritmo com o maracá, conduzindo as relações estabelecidas com os Encantados. O maracá Pankararu é feito a partir do coité, uma cabaça na qual são inseridas sementes e que reproduzem o som característico quando balançadas. Para muitas das comunidades indígenas, incluindo os Pankararu, os maracás atuam como uma ligação entre o mundo material e o sobrenatural.

No entanto, há uma diferenciação entre os toantes e os torés. Os toantes possuem um caráter sagrado e são utilizados para evocar a presença ou estabelecer contato a presença com os Encantados, existindo momentos apropriados para entoá-los, seja nos rituais que contam com a presença dos Praiás ou nas "mesas de cura". Nos rituais, eles são entoados por um cantador ou cantadeira, acompanhados pelo maracá, empregando vocalizações sem sentido aparente e é ao som deles, que os Praiás, as representações físicas dos Encantados, dançam. Durante o ritual, cada toante é cantado três vezes: cada três ciclos do mesmo toante são chamados de rodada, que é finalizada quando os Praiás convergem para o cantador e emitem um som uníssono em tom mais alto. A origem dos

\footnotetext{
${ }^{17}$ Torna-se necessário realizar uma distinção textual em relação ao termo Toré, uma vez que se referem a dois aspectos diferentes. Assim, utilizaremos toré (com minúscula) em caso de modalidade vocal e Toré (com maiúscula) quando se trata do ritual em si.
} 
toantes, em geral, está associada ao levantamento de um Praiá, ou vale dizer, ao surgimento de um novo Encantado.

Já os torés, apesar de pertencerem também aos Encantados, são executados para que todos possam cantar e dançar. Possuem letras em português e podem ser realizados nos mais diversos momentos e locais (na aldeia ou nas cidades; em festas públicas ou particulares) e cumprindo as mais variadas finalidades (como instrumento político ou para finalizar um ritual).

De acordo com Cunha (1999), em termos musicais, toantes e torés obedecem à mesma lógica. Possuem uma estrutura composta de três partes, sendo que nas duas primeiras são cantadas as estrofes. Na terceira e última parte, encontra-se o trecho que é repetido várias vezes antes de voltar ao início. Em determinados momentos, o cantor e os participantes cantam na forma de chamado e resposta. A diferença está no ritmo, com os torés sendo cantados em um volume mais alto e de forma mais acelerada do que os toantes.

É por meio da música que os Pankararu invocam ou 'chamam' os Encantados, seja durante cerimoniais específicos, como nos casos de cura, seja nos rituais ou festas que são realizados pelos Pankararu, como o Menino do Rancho, o Cerimonial do Ajucá ou a Festa do Umbu - esta última a maior e constituindo-se no mais importante cerimonial dos Pankararu (cf. Cunha, 1999). Seria interessante que adentrássemos em mais detalhes em cada festa ou ritual, pois estes são elementos importantes para a coletividade indígena Pankararu.

Como caráter de ritual, temos o Cerimonial do Ajucá, no qual os mais velhos e iniciados no segredo da comunidade Pankararu ingerem a Jurema ${ }^{18}$ para entrar em contato com os Encantados para situações de aconselhamento e tomada de decisões. Não sendo uma cerimônia pública, não é permitida a participação de não-iniciados e estranhos. Nessa ocasião, apenas os toantes são cantados.

Na Noite da Novena, na cidade de Tacaratu, nas adjacências da Terra Indígena, não se canta nenhum toante. É apenas depois de participarem da missa que os Pankararu cantam e dançam diversos Torés na frente da igreja da cidade. O Toré, nesse caso, passa a se caracterizar um ato público e político pelo fato de este evento representar para os Pankararu a declaração de que a área na qual a igreja se localiza,

\footnotetext{
${ }^{18}$ A jurema é uma bebida considerada sagrada, presente nos trabalhos espirituais de diversos grupos indígenas do nordeste brasileiro. É feita das raízes de um arbusto de mesmo nome e bebida em alguns rituais, para um contato com o mundo dos espíritos e com os ancestrais do grupo étnico (cf. Albuquerque, 2006).
} 
assim como boa parte do território que pertence à cidade de Tacaratu, ter pertencido, em um passado remoto, aos antepassados Pankararu.

O cerimonial do Menino do Rancho também é considerado um ritual, mais especificamente, um rito de passagem, no qual um menino é iniciado nos segredos Pankararu. Sem uma data específica para ser realizada, geralmente ocorre quando um menino da aldeia fica doente e os pais, na busca da cura, realizam uma promessa aos Encantados que se concretizará no ritual do Menino do Rancho. Como cumprimento da promessa, após um período de preparação, o menino é colocado pelo Pajé em um rancho para protegê-lo dos maus espíritos. O ritual comporta um compromisso matrimonial entre o menino e uma menina do grupo, embora hoje raramente o casal prometido, na vida adulta, concretize esta união. Desse modo, uma menina é convidada para representar o papel de noiva. Além disso, são convidados duas madrinhas, os Praiás e padrinhos ou defensores do menino. A cerimônia começa de manhã com a chegada da noiva e das madrinhas. Os Praiás tentam pegar o menino, que é defendido pelos padrinhos, em diversas vezes, quando ele é devolvido aos pais ao final da tarde. Os toantes ocupam a maior parte do evento, sendo que, no encerramento, o Toré (tanto a música quanto a dança) é realizado, havendo então a participação de todos no canto e na dança.

O Toré, por sua vez, pode ser considerado uma festa, já que é permitida a participação de todos, tanto nas músicas, quanto nas danças, além do fato de ser um evento que tem como uma de suas funções a reunião do grupo. Em geral, um cantador ou cantadeira dá início ao evento com um toante de abertura. Após a execução de três toantes (três rodas) é que os torés (músicas) podem ser cantados em seguida. Diferente de outros cerimoniais, nos Torés, os cantadores se posicionam no centro do círculo, cantando e girando junto com todo o resto dos participantes, permitindo também a participação de mais cantadores, e não apenas um como nos outros cerimoniais.

O maior e mais complexo dos eventos Pankararu é a Festa do Umbu. Ela pode ser considerada uma festa que tem um caráter aglutinador, quando se desenvolve o Toré, mas que envolve também diversos rituais, como o Flechamento do Umbu ${ }^{19}$, a Noite dos Passos e a Queima do Cansanção ${ }^{20}$. A festa é realizada durante os sábados e domingos dos meses de fevereiro e março e comemora o início da safra do umbu.

\footnotetext{
${ }^{19}$ O Flechamento do Umbu é uma cerimônia realizada sempre no mês de dezembro, quando aparecem os primeiros umbus. O umbu, fruta do umbuzeiro, é típica do Nordeste e muito apreciada pelos Pankararu, assim como os habitantes nordestinos. O primeiro umbu maduro é trazido ao dono do terreiro do poente e preso em um fio entre duas forquilhas. Com isso, os índios pintados de branco e os Praiás, armados de arco e flechas, tentam um a um flechar o umbu maduro.
} 
Durante essa festa, a música é conduzida do mesmo modo que no Menino do Rancho, com apenas duas diferenças. Na primeira, os tocadores executam a música de gaita e cabo de tatu para acompanhar as mulheres carregando cestos em todo o percurso que vai do terreiro secundário para o terreiro principal. Neste momento, os tocadores se juntam aos cantadores para liderar a pequena procissão que acompanha as mulheres e seus cestos. É o único momento em que se observam os tocadores de gaita e os tocadores atuarem juntos. A segunda ocorre no momento do ritual da Queima do Cansanção. Neste momento, os tocadores da gaita e do cabo de tatu se apresentam sozinhos, sem o acompanhamento do cantador. A cerimônia termina com o Toré, com a participação de todos dançando e cantando, no centro do terreiro. A festa dura quatro finais de semana, com a repetição das mesmas performances. A diferença ocorre apenas no último fim de semana, quando ocorre o ritual mais importante para os Pankararu, o momento em que o Mestre Guia, o Encantado principal, aparece para benzer os participantes. Essa breve e única aparição é acompanhada por um cantador especial, que canta apenas os três toantes pertencentes a este Encantado. Em pouco tempo, o Mestre Guia aparece, benze várias pessoas presentes e, ao fim dos toantes, se retira para retornar apenas no ano seguinte.

De acordo com depoimento de lideranças Pankararu em São Paulo, a maior parte desses rituais tem de ser realizados em um terreiro sagrado, não podendo ser feitos na metrópole paulistana por não haver um espaço adequado para isso. Esse é um das razões pelas quais os indígenas Pankararu do Real Parque reivindicam um território no Estado de São Paulo, fato que permitiria a eles realizarem estes rituais, que poderiam se tornar elementos aglutinadores que contribuiriam para uma maior coesão social e cultural dos Pankararu em São Paulo.

\section{O etnônimo Pankararu}

\footnotetext{
${ }^{20}$ A Queima da Cansanção é uma dança que é realizada durante a Festa do Umbu. É realizada durante todos os sábados e domingos do mês de março e comemora o início da safra do umbu.
} 
Os primeiros contatos sistemáticos com o grupo Pankararu foram estabelecidos por missionários que, no início do século XVII, avançavam sertão adentro a partir de Santo Antônio da Glória, na Bahia.

O etnônimo Pankararu, de acordo com Hohenthal (1960), remonta ao ano de 1702, em um relatório produzido por jesuítas a respeito do aldeamento de Nossa Senhora de Ó, na ilha de Sorobabel, localizada no rio São Francisco. Nesse aldeamento, juntamente com os Pankararu, são citados também os Cararu, os Tacaruba e os Poru. Hohenthal (1960) sugere que os Pankararu e os Poru se agregaram à aldeia entre 1696 e 1702. Posteriormente, os Pankararu e os Poru se localizariam nos aldeamentos de Nossa Senhora do Belém, em 1845, e Beato Serafim, em 1846, que estariam sob a organização dos capuchinhos italianos nas ilhas de Vargem e do Acará, também localizados no Rio São Francisco.

O aldeamento "Brejo dos Padres" foi criado provavelmente em 1802 por obra de missionários oratorianos ou capuchinhos a partir da junção dos grupos Pankararu e Poru com outros grupos denominados Umans, Vouves e Jeritacós. A territorialidade do grupo Pankararu é compreendida por dois marcos geográficos tomados como sagrados: a cachoeira de Paulo Afonso, local onde seus ancestrais teriam sucumbido a um dilúvio, e a cachoeira de Itaparica, tradicional local de sepultamento de seus mortos, logo transformado em cemitério cristão pelos missionários.

A extinção do aldeamento foi realizada de forma arbitrária e violenta na década de 1870 por parte dos grandes fazendeiros locais. Para a população que habitava o aldeamento, a visão é de que ele não se extinguira, mas sim de que parte das famílias indígenas foi expulsa, sendo que outra parte se dispersara, e que invasores se estabeleceram no local por meio de demarcação de lotes nas terras, perpetrando "linhas" de divisão dos terrenos, sendo, por isso, denominados de "linheiros".

Os indígenas que permaneceram, conviveram, portanto, com uma situação de "mistura" (termo denominado por eles), o que, no entanto, não extinguiu a vida ritual, mas prosseguiu de forma mais discreta, não mais em terreiros coletivos, mas sim em vários terreiros menores correspondentes às unidades familiares dispersadas. Provavelmente, seria nesse período que o Toré, tanto praticado no Nordeste como em São Paulo, se tornaria autônomo de outros rituais nos quais era um elemento constante.

No momento da recriação da aldeia, proporcionada pela mediação de padre Dâmaso e do antropólogo Carlos Estevão, e do reconhecimento da terra indígena, o etnônimo adotado oficialmente foi Pankaru (posteriormente Pankararu), mas na 
memória dos mais velhos o verdadeiro nome seria uma junção de sobrenomes "Pancaru Geritacó Cacalancó Umã Tatuxi de Fulô" -, sendo que cada sobrenome ${ }^{21}$ corresponderia a uma das outras principais etnias que compuseram historicamente o grupo. A lembrança desse nome teria como função guardar a memória da diversidade étnica que compõe o grupo, como forma de resistência à homogeneização imposta. Segundo Arruti (1995), guardar esses sobrenomes teve o sentido de constituir uma unidade política e social sem que fosse necessário apagar os vestígios da diferença. Se para a SPI e posteriormente a FUNAI, o reconhecimento de um grupo indígena envolveria a construção de uma identidade entre um etnônimo e um recorte territorial, ou seja, ser um Pankararu significaria ocupar um território Pankararu, esses sobrenomes "representam um recurso simbólico e político que lhes permite romper com a imobilidade imposta pelo território legal-administrativo definido pelo órgão indigenista" (Arruti, 1995, p. 37).

De acordo com o antropólogo, tanto o etnônimo como o grupo social que é identificado como Pankararu são decorrentes de um processo de transfiguração que caracteriza os indígenas do Nordeste. Sendo assim, a unidade Pankararu não é o ponto de partida nem o produto final, mas sim uma "cristalização étnica de transformações históricas, ponto de convergência e de dispersão de outras construções sociais e invenções culturais" (Arruti, 1995, p. 33). Para Arruti:

Segundo os Pankararu, cada um dos seus sobrenomes permite que do grupo se solte um 'enxame' para constituir um novo grupo, uma nova ponta de rama. Se, no passado, diferentes grupos puderam ser reunidos num mesmo território como estratégia de sobrevivência, porque não pensar que hoje, também como estratégia de sobrevivência, um grupo possa dar origem a outros, multiplicando os territórios indígenas? (Arruti, 1995, p. 38).

A preservação desses sobrenomes - "Pancaru Geritacó Cacalancó Umã Tatuxi de Fulô" - é que proporcionou a possibilidade de se firmar uma unidade política e social sem que houvesse uma perda definitiva dos elementos que também as diferenciavam.

\footnotetext{
${ }^{21}$ O termo "sobrenome" aqui é utilizado para designar os nomes das etnias citadas, sendo que o "etnônimo" seria o nome do grupo étnico que foi cristalizado para determinar os indígenas Pankararu.
} 


\section{As metáforas da emergência étnica}

Interpretamos a utilização de termos como "enxame" e "ponta de rama" como metáforas que são utilizadas para descrever o processo de emergência étnica. Os caminhos de emergência étnica assumem, por parte de seus atores, significações próprias que se traduzem em um "reencantamento do mundo", como denomina Arruti (1995). O chamado "reencantamento" se realiza por meio de ritos, formação de mitos, recuperação de imagens e relações que foram esquecidas e são os seus aspectos simbólicos, como um sistema de metáforas, que possibilitam a explicação e a inteligibilidade do processo emergente para os povos indígenas do Nordeste, em especial os Pankararu. Entre as metáforas que são estabelecidas, temos os pares "troncos velhos/pontas de rama" e "enxames/levantar aldeias".

\section{A relação entre "Enxames" $e$ "Levantamento de aldeias"}

O termo "enxame", retirado do mundo natural, nos conduz à visão de constituição de novas unidades por via do processo de movimento, expansão e fracionamento. Esse sistema de metáforas surge da relação entre o par "tronco/ponta" e o composto dos sobrenomes. Já o termo "levantar aldeia", por outro lado, expressa o esforço e o trabalho realizado por um determinado grupo no auxílio à emergência de outro grupo, independente da reivindicação de qualquer laço de parentesco.

Dessa forma, 'enxamear' e 'levantar aldeia' são movimentos complementares e fazem a ligação entre os pólos 'troncos velhos' e 'pontas de rama': o enxame, como um movimento compulsório, num tempo situado entre o histórico e o mítico, partindo dos troncos velhos para as pontas de rama, na forma de migração; o levantamento das aldeias, como um movimento voluntário de caráter político e cultural, no tempo presente, partindo das pontas de rama para os troncos velhos, na forma de pedidos de apoio, e de volta, destes para as pontas de rama, na forma de apoio, legitimação ou de ensinamento do Toré (Arruti, 1995, p. 40).

\section{A relação entre os "Troncos velhos" e as "Pontas de Rama"}


Para uma descrição do processo de concentração, dispersão e cristalização étnica, Arruti (1995) registra um sistema de metáforas que se organizam segundo o par "Troncos Velhos/Pontas de Rama". A utilização do conceito para a compreensão da distância do grupo com os seus antepassados ou entre grupos mais antigos e novos no tocante às tradições e aparência física. Torna-se, assim possível, considerar grupos que são distintos, tanto em termos políticos como territoriais, como em termos de parentesco, partindo de referências ancestrais comuns, sejam elas reais ou imaginárias. Desse modo, amplia-se o pertencimento ao grupo "índios", em oposição a todos os "civilizados", "brancos" e "brasileiros".

As relações de oposição, continuidade e complementaridade entre "troncos" e "pontas" que ocorrem tanto dentro da comunidade Pankararu, quanto entre estes e os outros grupos, são utilizados como forma de pensar o tempo e seus efeitos, tendo como pano de fundo os laços naturais e experiências históricas (cf. Arruti, 1995). O par "Tronco/Pontas" não se refere, de forma isolada, a pessoas ou grupos, mas os posiciona em um sistema de relações que coloca assim uma distância em relação a um ideal de "índio puro".

Desse modo, os Pankararu poderiam ser "tronco velho" em relação a outros grupos, como os Kantaruré e os Jeripankó, que se constituirão como seus "enxames", mas já são "pontas de rama” em relação aos Karijó ou Xavante, com quem mantiveram contato em viagens de reivindicação em Brasília.

Esse sistema de metáforas permite descrever ou explicar o processo de emergências étnicas de outros grupos, que então formariam a grande árvore Pankararu: os Pankararu, os Jeripankó, os Kantaruré, os Kalancó, os Pancaru e os Pankararu do Real Parque, que passariam a se reivindicar como um "enxame", a partir do momento que passam a se constituir em associações em São Paulo em busca de seus direitos, principalmente de uma territorialidade. 


\section{Indígenas na cidade - Os Pankararu de São Paulo ${ }^{22}$}

Com o objetivo de nos aprofundarmos na compreensão da questão dos indígenas da cidade, utilizaremos alguns dados estatísticos disponibilizados pelo IBGE. O IBGE (Instituto Brasileiro de Geografia e Estatística), por meio do estudo Tendências Demográficas: uma Análise dos Indígenas com Base nos Resultados da Amostra dos Censos Demográficos 1991 e 2000, realizou uma análise populacional dos indígenas autodeclarados com base nos questionários aplicados por amostragem dos respectivos censos (1991 e 2000). É importante ressaltar que foi a partir do Censo de 1991 que a categoria "Indígena" vem sendo pesquisada segundo o quesito "Cor ou raça", tendo como metodologia de captação de respostas a auto-identificação. Desse modo, foram recenseados indivíduos que se auto-identificam como indígenas, tanto em terras indígenas, como em áreas rurais fora dessas terras, ou mesmo em áreas urbanas. Foi uma mudança importante, uma vez que o Censo passou a levar em conta os indígenas que não habitavam em terras tradicionais, mas que não deixavam de se autodeclarar indígenas ou que passaram a fazê-lo a partir de um determinado momento em razão de diferentes conjunturas.

De acordo com o Censo do IBGE de 1991, existiam aproximadamente 294 mil indígenas no país, indicando um percentual de $0,2 \%$ em relação à população total brasileira. Já as estatísticas do Censo do IBGE de 2000 demonstraram a existência de aproximadamente 734 mil indígenas ${ }^{23}$ no Brasil, elevando a porcentagem desse segmento para quase $0,4 \%$ da população nacional. Isso indica um crescimento absoluto, no período intracensos, de cerca de 440 mil indivíduos, ou seja, um acréscimo de mais de $100 \%$, a maior taxa de crescimento dentre todas as categorias de cor ou raça. Esse aumento de indígenas autodeclarados foi verificado, em maior ou menor grau, em todos os estados, embora com mais destaque nos estados da Região Sudeste, em especial, o estado de São Paulo, que apresentou um aumento de 2.939,28\% em relação aos dados da Fundação Nacional do Índio (FUNAI), Fundação Nacional de Saúde (FUNASA) e

\footnotetext{
${ }^{22}$ Este capítulo foi escrito com base em pesquisa documental e depoimentos colhidos entre os membros da comunidade Pankararu do Real Parque, em São Paulo, no período compreendido entre 2006 e 2008, além do acompanhamento, registro e auxílio nas atividades realizadas pela Associação S.O.S. Comunidade Indígena Pankararu.

${ }^{23}$ Cabe ressaltar as diferenças que são observadas nos números apresentados por outras instituições de relevo que realizam levantamentos populacionais indígenas: o ISA registrou em 2000 o número total de 336.919 indígenas no país. A FUNAI registrou em 2006 a população indígena em um número aproximado de 425.000 indivíduos. As discrepâncias observadas nestes números demonstram a real dificuldade na definição e auto-definição da identidade indígena e também a precariedade das fontes de dados demográficos.
} 
Instituto Sócio-Ambiental (ISA) (cf. Adorno et alli, 2004). Os dados apresentados provocaram diversas discussões entre especialistas, antropólogos e órgãos indigenistas, colocando em xeque tanto os dados apresentados pelo Censo Demográfico como também os que vinham sendo apresentados por órgãos e $\mathrm{ONG}^{\prime}$ s atuantes no indigenismo e universidades. Algumas hipóteses explicativas foram aventadas para essa explosão demográfica: a) o crescimento vegetativo dos indígenas; b) a imigração internacional de indígenas de países que fazem fronteira com o Brasil e que possuem alto contingente de população nativa, como Bolívia, Equador, Paraguai e Peru; e c) o aumento da proporção de indígenas autodeclarados em áreas urbanas que anteriormente se classificavam em outras categorias, incluindo pessoas que não se identificavam com nenhuma etnia especificamente. Embora essas hipóteses não se excluam, a última hipótese (c) pode ser considerada como uma das mais plausíveis. De qualquer modo, tais mudanças demonstram uma inflexão histórica na tendência de desvalorização da identidade indígena (cf. Censo de 1991), e indicam um claro processo de revalorização da identidade étnica e/ou de sua ascendência indígena (Adorno et alli, 2004).

Em relação ao aspecto da localização dos indígenas, no Censo de 1991, de um total de 294 mil indígenas, 223 mil foram recenseados indígenas nas zonas rurais (76,1\% do total), enquanto que 71 mil habitavam em áreas urbanas (23,9\%). Comparativamente, entre os 734 mil indígenas recenseados em 2000, 384 mil estavam presentes em áreas urbanas e 350 mil em áreas rurais. Poder-se-ia concluir que, pelas estatísticas do IBGE, pouco mais que a metade dos indígenas do Brasil (52,0\%) vive atualmente nas pequenas e grandes cidades do país ou em suas adjacências. Embora seja alvo de grandes controvérsias, este é um dado que merece grande atenção porque foram as áreas urbanas de todas as regiões brasileiras que tiveram aumentos significativos e absolutos de indígenas. Esse aumento da proporção da população indígena urbana pode ter ocorrido devido a três possíveis fatores: a) o próprio crescimento vegetativo nas áreas urbanas; b) a migração de indígenas, sobretudo dentro do próprio estado, com destino a áreas urbanas e a transformação, em pequena escala, de áreas consideradas rurais, segundo censos anteriores em áreas urbanas. Outro fator, bastante relevante e indicativo, foi a de uma maior taxa de autodeclaração de indígenas nas regiões Sudeste e Nordeste, que, paradoxalmente, têm menor número de terras indígenas homologadas, mas foram regiões nas quais tem havido importantes movimentos de reemergência étnica indígena. Outro movimento a ser observado é o das migrações, que ocorrem por uma diversidade de motivações, incluindo dificuldades no local de origem ou mesmo 
expectativas em relação ao local de destino. Pela análise dos censos dos últimos cinco anos, percebeu-se que o principal movimento migratório das populações indígenas ocorreu em direção à região Sudeste, em especial no sentido Nordeste-Sudeste - 3.673 pessoas saíram do Nordeste para o Sudeste (Silva et alli, 2006).

Ainda no censo de 2000, o IBGE registrou uma população de 63.789 indígenas no Estado de São Paulo. Isso faz com que São Paulo se torne o terceiro maior Estado em termos de população indígena do Brasil, sendo superado apenas pelos Estados da Amazônia (113.391 indígenas) e Bahia (64.240 indígenas). Do total da população indígena do Estado de São Paulo, aproximadamente 58.842 habitantes vivem em áreas urbanas, enquanto que um total de 4.946 indígenas vive em áreas rurais. Já a Pesquisa Nacional por Amostra de Domicílios (PNAD) do IBGE de 1998 indicava uma população de 33.829 indígenas na Região Metropolitana de São Paulo ${ }^{24}$.

Segundo o Relatório Índios na Cidade de São Paulo (2005), da Comissão PróÍndio, existem três terras indígenas Guarani no município de São Paulo: Jaraguá, Krukutu e Tenondé Porã. Além da etnia Guarani, outras dezenas de comunidades indígenas de etnias originárias de diversas regiões do País vivem na região metropolitana de São Paulo. A maior parte das populações indígenas presentes em São Paulo é proveniente do Nordeste, região na qual os povos indígenas sofreram historicamente grandes perdas territoriais e tiveram suas condições de sobrevivência severamente prejudicadas. Além dos povos indígenas do Nordeste, são encontrados também membros de etnias como o dos Têrena (presentes em Mato Grosso do Sul), dos Xavante (presentes em Mato Grosso) e dos Kaingang (presentes na região centro-oeste do Estado de São Paulo). Do ponto de vista oficial - ou seja, reconhecidos pela FUNAI -, somente os Guarani são considerados indígenas, embora indígenas de outras etnias estejam sendo identificados, ou em processo de identificação, pela FUNASA/SP e outros serviços de saúde. Não há, entretanto, uma sistematização dos dados de atendimento de saúde aos indígenas. Segundo dados da FUNASA (2007), estão cadastrados para atendimento de saúde 1.905 indígenas na cidade de São Paulo das seguintes etnias: Atikum, Fulni-ô, Guajajara, Jeripankó, Kaimbé, Kambiwá, Katokin, Pankararé, Pankararu, Pataxó, Potiguara, Têrena, Tuxá, Wassu, Xukuru e XukuruKariri.

De acordo com Baines (2001), a questão dos indígenas ou aldeias indígenas na cidade abrange toda uma gama de situações diversas, com históricos diferentes de

\footnotetext{
${ }^{24}$ Observamos novamente as discrepâncias entre os números apresentados pelos órgãos responsáveis.
} 
contato interétnico com populações locais, envolvendo desde situações relativas à expulsão de indígenas de suas terras tradicionais até situações em que os indígenas optaram por viver na cidade em razão da falta de oportunidades de educação e emprego e de atendimento adequado de saúde em suas terras originais.

Um aspecto a ser observado é que a política de assistência aos indígenas delineada pelo governo federal é voltada basicamente para os índios que vivem em aldeias, em geral nas localidades mais afastadas dos grandes centros urbanos, sendo ineficaz, entretanto, para desenvolver programas de assistência aos índios que vivem nas cidades. A legislação brasileira também não trata da questão dos chamados "índios desaldeados" e não contempla a necessidade de atendimento diferenciado a uma situação como essa, colocando os indígenas presentes nas cidades em uma espécie de limbo jurídico, dificultando ou impedindo-os de usufruírem de seus direitos. O próprio modelo de classificação de "aldeados" e "desaldeados" é considerado por demais simplista e não abrange a complexidade da questão, sendo rejeitado, tanto pelas comunidades indígenas que moram nas cidades, como pelos grupos indígenas considerados "aldeados" (Adorno et alli, 2004), mas que é perpetuado pelos órgãos indigenistas encarregados de dar suporte aos indígenas. Segundo Bruce Albert, “baseado numa oposição caricata entre índios 'aldeados' e 'desaldeados' e na idéia redutora da passagem de mão única de um estado social [rural/tradicional] a outro [citadino/deculturado], este modelo só inverte, de fato, a visão colonial-evolucionista tradicional segundo a qual ir da floresta a cidade era percorrer o caminho do primitivo ao civilizado" (Albert, 2000, s/p).

$\mathrm{O}$ fato de os indígenas morarem em cidades tem sido equivocadamente compreendido como um indicador do desejo dos indígenas de não conservação de sua condição indígena, deduzindo-se automaticamente a renúncia à proteção já garantida pela legislação. Essa compreensão não leva em conta toda uma série de processos históricos de opressão e discriminação e gera espaço para novos tipos de preconceitos, ainda não devidamente tratados pela legislação brasileira. Em geral, a tentativa dos indígenas da cidade de fazer valer os seus direitos acaba por resultar em tipos diversos de preconceito e discriminação, que consistem em desqualificar suas pretensões aos thes negar a condição de indígenas e, mesmo que haja esse reconhecimento, sem traduzi-las em garantia dos direitos correspondentes (cf. Araújo e alli, 2006).

Os dados apresentados até agora demonstram que a questão dos indígenas na cidade tem assumido proporções que exigem e irão exigir atenção cada vez maior das 
políticas públicas, dos órgãos indigenistas e também das organizações internacionais como a ONU. Como exemplo da atenção que a migração dos indígenas aos centros urbanos tem despertado, o Foro Permanente para as Questões Indígenas das Nações Unidas, em seu sétimo período de sessões, realizado entre os dias 21 de abril e 2 de maio de 2008, em Nova York, elegeu a migração urbana dos povos indígenas como uma de suas prioridades de discussão. Não se pode esquecer que os próprios indígenas que moram nas cidades têm se articulado e organizado em busca de seus direitos, sendo os indígenas Pankararu um exemplo bastante contundente.

\section{Os Pankararu de São Paulo}

A questão dos indígenas nas cidades é resultado, em geral, dos processos de deslocamento de indígenas de suas terras tradicionais para cidades mais próximas, em um primeiro momento, para uma locomoção posterior para cidades maiores ou para os centros urbanos que são, em geral, os pólos históricos de migração do país, como é o caso da cidade de São Paulo.

A migração de indígenas Pankararu do Nordeste para São Paulo é um claro exemplo de todo este processo. A população dos Pankararu na cidade de São Paulo surgiu a partir dos deslocamentos de cerca de $2.200 \mathrm{~km}$ de trabalhadores Pankararu da Terra Indígena Pankararu no Nordeste para as grandes cidades do Sudeste a partir da década de 1950. Segundo Matta (2005), a migração é justificada por motivações como a busca de melhores condições de sobrevivência, em uma tentativa de suprir as necessidades vitais e básicas em meio às condições adversas - como a escassez de terras, períodos prolongados de seca e falta de emprego - aliadas ao desejo e à necessidade de consumo.

No entanto, os aspectos citados se restringem apenas ao plano econômico. A migração também pode representar a busca ou uma possibilidade de obter algo que vai além do estritamente "necessário" à sobrevivência, como, por exemplo, realizar benfeitorias em suas residências situadas na Terra Indígena ou compras de animais que poderiam gerar renda posterior. Ou ainda oferecer uma perspectiva de melhores condições de vida para seus descendentes, como se pode depreender do seguinte depoimento: 
Eu não queria que eles [meus filhos] passassem pelo que eu passei. Vivendo de roça, trabalhando em cima das serras, sendo que as terras melhores os posseiros que tinham. Então chega uma hora que a gente planta e vê morrer por causa do sol. Aí a gente cai em desespero. E é obrigado a tentar a sorte na terra dos outros. (Bino Pankararu, liderança da comunidade indígena Pankararu em São Paulo ${ }^{25}$ ).

Segundo Arruti (1995), os primeiros trabalhadores Pankararu em São Paulo foram dirigidos para serviços de desmatamento da Cia. de Luz do Estado na década de 1950. O contato inicial com estes trabalhadores era feito por "gatos"26, que se encarregavam de buscá-los na própria aldeia para entregá-los em grupos aos "empreiteiros" das obras. Posteriormente, um destes trabalhadores acabou por se elevar ao papel de "gato" e, depois, ao de empreiteiro das obras de desmatamento da Cia. de Luz. Isso possibilitou o fluxo direto e constante entre Brejo dos Padres e São Paulo nas décadas de 1950 e 1960. Os trabalhadores Pankararu também participaram da construção do Palácio do Governador e do estádio do Morumbi ${ }^{27}$, que teve seu início na década de 1950 e terminou em 1960, fato que assume uma conotação especial entre os próprios Pankararu, e que seria uma das explicações do fato de residirem em uma comunidade nas adjacências do Morumbi, bairro nobre da cidade de São Paulo.

No entanto, a partir da década de 1990, os deslocamentos se acentuaram drasticamente em virtude do acirramento das dificuldades de subsistência na Terra Indígena do Nordeste. Do mesmo modo que muitos nordestinos não-indígenas, que vieram em busca de melhores condições de vida na cidade, os trabalhadores Pankararu acabaram por experimentar as mesmas situações de penúria e as mais difíceis condições de sobrevivência vivenciadas por aqueles, ao se juntarem à massa de subempregados das favelas, sendo que a maior parte dos homens acabou por subsistir a partir da renda obtida na construção civil e as mulheres, como empregadas domésticas.

A primeira geração de trabalhadores Pankararu saiu da Aldeia para trabalhar curtos períodos em São Paulo, não se integrando, portanto, de forma plena à cidade. Já a segunda geração de trabalhadores em São Paulo teve como característica marcante a intensificação do fluxo de mulheres para a metrópole, que passaram a constituir um local específico de permanência mais estável. Com um núcleo familiar instalado e a

\footnotetext{
${ }^{25}$ Vídeo "Do outro lado do rio - os Pankararu do Real Parque" (2005), de Carolina Motoki.

${ }^{26}$ Termo popularmente dado aos agenciadores ou empreiteiros de trabalhadores na construção civil.

${ }^{27}$ Estádio pertencente ao São Paulo Futebol Clube.
} 
diminuição de custos materiais e afetivos, as migrações dos mais jovens também foram facilitadas, permitindo assim uma reterritorialização desses indígenas. Com o decorrer do tempo, São Paulo passou a se constituir como uma referência territorial para todo o grupo indígena (cf. Arruti, 1996).

Em 1994, devido a notícias veiculadas na mídia impressa e nos telejornais de um jovem Pankararu assassinado ${ }^{28}$, a presença indígena Pankararu no bairro Real Parque adquiriu maior visibilidade, o que possibilitou a emancipação do discurso das lideranças do núcleo do Real Parque das lideranças da Aldeia do Brejo dos Padres.

$\mathrm{O}$ fato de indígenas morarem em condições precárias nas grandes cidades também despertou a atenção dos meios de comunicação, que passaram a realizar reportagens que visavam retratar o modo de vida destes indígenas e também o efeito que a discriminação tem provocado sobre a afirmação étnica dos indígenas Pankararu. O jornal Folha de São Paulo, em uma reportagem do dia 8 de novembro de 1997, descreve que o medo do preconceito tem obrigado os indígenas que moram em São Paulo a esconder as suas origens para obter emprego, apresentando-se então como negros, nordestinos ou índios argentinos (cf. Folha de São Paulo, 1997). Segundo depoimento de Bino Pankararu, em uma reportagem do mesmo jornal Folha de São Paulo, de 2 de março de 1997:

Nem sempre falo que sou índio. Só apresento minha carteira (que revela que ele é do Posto Indígena Pankararu) depois de estar trabalhando. Se apresento antes, dizem que índio é preguiçoso. (Bino Pankararu, FOLHA DE SÃO PAULO, 02/03/1997)

Além de sofrerem discriminação por parte da sociedade, os Pankararu de São Paulo não eram reconhecidos como indígenas por não se enquadrarem no estereótipo do índio genérico, vinculado ao imaginário passadista e romântico: de índio que habita na mata, possui pouca ou nenhuma vestimenta, tem um idioma próprio e é portador de um determinado biótipo. Em razão disso, a identidade de indígena era negada por órgãos indigenistas e públicos e também pelas pessoas com quem mantinham um

\footnotetext{
${ }^{28}$ Segundo Arruti (1996), foi no dia 26 de julho de 1994 que os Pankararu passariam a adquirir maior visibilidade na mídia com a manchete do assassinato de um jovem Pankararu do jornal Notícias Populares de São Paulo. O jornal Folha de São Paulo, duas semanas depois, dedicou uma página inteira para noticiar a existência de uma comunidade indígena em pleno Morumbi. Uma semana depois o Diário de Pernambuco publicou uma reportagem com o título "Pankararu que trabalham em São Paulo estão sendo dizimados pela violência urbana".
} 
relacionamento nas cidades. Iniciou-se, assim, um processo de reivindicação junto à FUNAI de reconhecimento dos membros da comunidade indígena Pankararu no Real Parque como indígenas, a despeito destes viverem fora das aldeias de origem, além de reivindicarem uma terra indígena em São Paulo. Uma associação foi criada neste mesmo ano como intuito de auxiliar os membros da comunidade a se organizarem politicamente e terem acesso aos direitos indígenas garantidos pela legislação. Embora estejam espalhados em diversos bairros e municípios da grande São Paulo, foi na comunidade do Real Parque que os Pankararu puderam adquirir visibilidade, respeito e poder de negociação para a busca e consolidação de seus direitos como indígenas, levantando diversas questões a respeito dos índios na cidade, tanto para o Estado como para os órgãos indigenistas (cf. Matta, 2005).

As propostas dos Pankararu do Real Parque, no entanto, acabariam por se tornar conflitantes com os interesses das lideranças dos Pankararu em Pernambuco, bem como com os da FUNAI. Entre outros fatores, estava em litígio o estatuto das viagens a São Paulo. A questão colocada é que as reivindicações de terra e os projetos de desenvolvimento requeridos pela Terra Indígena do Brejo dos Padres contabilizavam também a população Pankararu presente no Real Parque como beneficiários, o que implicava em mais recursos por parte dos órgãos públicos para a Terra Indígena Pankararu no Nordeste. O deslocamento dos Pankararu para São Paulo era considerado até então uma diáspora, mas com as novas reivindicações por parte da população no Real Parque, ela se convertia em mais um "enxame"29, o que caracterizaria o exílio econômico em reterritorialização étnica. Confirmava-se, assim, o movimento de fragmentação e expansão da identidade Pankararu, o que contrariava a estratégia política do Brejo dos Padres (cf. Arruti, 1996).

\footnotetext{
${ }^{29}$ Conforme explicitado no capítulo 1 desta dissertação.
} 


\section{A população Pankararu em São Paulo}

Segundo dados da FUNASA (2007), 1340 indígenas Pankararu vivem na cidade de São Paulo. No entanto, a Associação SOS Comunidade Indígena Pankararu informalmente contabiliza um número aproximado de 2.000 Pankararu $^{30}$. Os Pankararu de São Paulo formaram vários núcleos populacionais em diversos bairros da periferia da Grande São Paulo. O maior número de famílias Pankararu se concentra no bairro Real Parque (aproximadamente 430 pessoas distribuídas em 152 famílias) e o restante se encontra espalhado por cerca de 30 bairros $^{31}$ e 20 municípios $^{32}$ da Região Metropolitana de São Paulo.

Em especial no bairro Real Parque, a maior parte dos Pankararu reside em condições precárias, em barracos pequenos de alvenaria e sem recursos de saneamento básico. As condições de subsistência também são difíceis, pois a maior parte deles não possui carteira de trabalho assinada e sobrevive de "bico". Após diversas negociações em busca de melhores condições de habitação, os Pankararu do Real Parque conseguiram se instalar em dois prédios do conjunto Cingapura ${ }^{33}$, nos quais moram atualmente 24 famílias (12 em cada prédio).

Para Matta (2005), a ligação entre aldeia e São Paulo está devidamente instituída, havendo uma complementaridade intrínseca entre ambas as partes. A aldeia

\footnotetext{
${ }^{30}$ Os dados sobre a população Pankararu não são precisos. São diversas as estimativas: 1.500 índios em Arruti (1999) e Matta (2007); 1.200 no relatório da Comissão de Direitos Humanos da Assembléia Legislativa de São Paulo (2002); 1.000 em Carneiro da Cunha (1999); 1.000 em Medeiros (2004); e 950 em Cosso (2002).

31 Bairros em que os Pankararu estão presentes: Brasilândia, Cachoeirinha, Campo Limpo, Capão Redondo, Casa Verde, Cidade Ademar, Cidade Dutra, Cidade Líder, Jaraguá, Ermelino Matarazzo, Grajaú, Iguatemi, Itaim Paulista, Jardim Ângela, Jardim São Luiz, Lajeado, Morumbi (Real Parque), Parelheiros, Pedreira, Perus, Ponte Rasa, Raposo Tavares, Rio Pequeno, Sacomã, Santo Amaro, São Rafael, Sapopemba, Vila Andrade, Vila Leopoldina e Vila Sonia.

${ }^{32}$ Municípios em que os Pankararu estão presentes: Arujá, Carapicuíba, Cotia, Embu das Artes, EmbuGuaçu, Ferraz de Vasconcelos, Francisco Morato, Guarulhos, Itapecerica da Serra, Itaquaquecetuba, Itapevi, Jandira, Juquitiba, Mogi Mirim, Osasco, Santana de Parnaíba, São Caetano do Sul, Santo André, Mauá e Taboão da Serra.

${ }^{33}$ O jornal Folha de São Paulo assim registra a notícia: "Vinte e oito famílias da tribo Pankararu receberam hoje do prefeito de São Paulo, Celso Pitta (PTN), apartamentos do projeto Cingapura. Eles faziam parte das 117 famílias de Pankararu que moram na favela Real Parque, no Morumbi, zona sul da cidade. Pitta foi presenteado com um colar feito pela tribo com rabo de tatu e pena de papagaio. Segundo os índios, o colar foi feito com esses animais porque são difíceis de se pegar, que têm o 'espírito muito forte'. (...) Ao serem contemplados com os apartamentos, os índios dançaram o 'toré' - uma dança de agradecimento aos espíritos Pankararu pelas novas casas. Eles pediram um terreiro e uma casa de reza porque as vestimentas sagradas e as danças precisam de um local específico. O povo Pankararu sabe que não é ideal morar em um apartamento. Eles queriam uma casa de chão para poder ir ao terreiro fumar e cuspir no chão. Mas os indígenas, que trabalham, já se adaptaram e sabem que não tinham outra alternativa senão aceitar os apartamentos. (...)” (Folha de São Paulo, 2000, s/p ).
} 
fornece aos Pankararu de São Paulo elementos como cultura, proteção, cura, 'força', recursos naturais e a certeza de que compartilham em comum uma terra, sendo proprietários dela por direito, assegurando-lhes um reconhecimento jurídico de posse e usufruto garantido pelo Estado. Essa complementaridade é ainda incrementada pela atribuição de valor que se dá ao indivíduo que se torna capaz de ou enviar bens materiais para a aldeia ou comprar terras, construir e reformar suas residências na aldeia, adquirindo, portanto um status diferenciado. Travar contato com a cidade de São Paulo e as possíveis benesses decorrentes disso - sejam elas materiais, sociais ou profissionais - assegura ao migrante uma qualificação diferenciada em relação aos que se encontram na aldeia.

\begin{abstract}
Possuir a chave desse acesso significa obter vantagens políticas, materiais e, muitas vezes, pessoais. Esse movimento econômico, de conhecimentos e valores, gera modificações na aldeia, além de colaborar com recursos para a realização dos rituais, seja na compra de matéria-prima para a confecção de Praiás ou na compra dos alimentos servidos nos momentos rituais. Essa circulação contínua garante um movimento que perpetua a identidade Pankararu. As carências, desejos e a busca daquilo que é mais do que o suficiente, não somente em recursos como em termos materiais são supridas na cidade, onde conquistaram espaço como índios Pankararu (Matta, 2005, p. 35).
\end{abstract}

Pode-se notar, em todo esse processo, a negação de qualquer evidência de que esteja havendo uma desintegração dos Pankararu como grupo. Se a vida na aldeia segue o seu percurso, uma nova frente e uma nova perspectiva se abrem para os Pankararu em São Paulo, havendo um fortalecimento geral do grupo étnico enquanto tal. De certo modo, a visibilidade dos Pankararu do Real Parque perante a sociedade nacional acaba por beneficiar o grupo étnico, como um todo, mas a custa de muito esforço e forte mobilização política. "Uma relação altamente dinâmica que cria 'mundos Pankararu' em ampla conexão, vinculados fortemente pelo 'mundo dos encantados"” (Matta, 2005, p. 36). Segundo Albert (2000), a realidade sociológica e cultural dos povos indígenas atualmente pouco a ver com uma ideologia "retroevolucionista" e um dualismo campo/cidade. Pode-se observar, atualmente, em diversas localidades, uma determinada realocação de grupos coletivos indígenas na forma de espaços sociais transversais - constituindo verdadeiras "comunidades multilocais" em 
escala regional - que articulam redes de parentesco e fluxos de bens e pessoas entre vários pólos situados nas florestas ou zonas rurais e na(s) cidade(s).

Assim, esta expansão translocal dos campos sociais indígenas e suas dinâmicas de mobilidade interna entre aldeias e cidades não podem ser confundidas, sob pena de se incorrer em cegueira conceitual, como um processo de migração das aldeias para as cidades (Albert, 2000, s/p).

\section{As associações indígenas}

Atualmente, no bairro Real Parque, verificam-se atuações de duas entidades indígenas que se articulam em torno das demandas da comunidade Pankararu: a) Associação S.O.S. Comunidade Indígena Pankararu, fundada em 1994 e reorganizada em 2003, que está sob a atual direção de Manoel Alexandre Sobrinho (Bino Pankararu); e b) ONG Ação Cultural Indígena Pankararu, fundada em 2003, sob a coordenação de Dimas Joaquim de Nascimento (Dimas Pankararu) ${ }^{34}$.

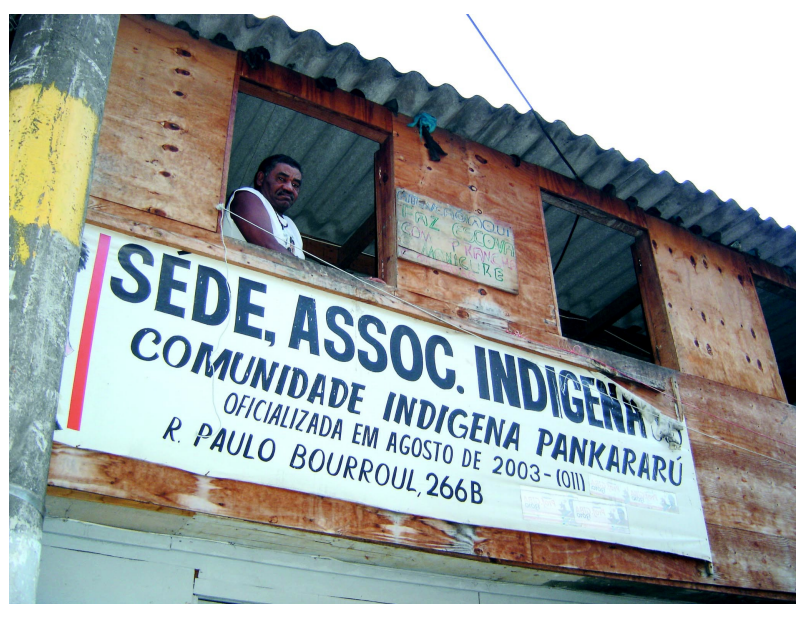

Crédito: Marcos Albuquerque

\footnotetext{
${ }^{34}$ A ONG Ação Cultural Indígena Pankararu surgiu como uma dissidência da Associação Indígena SOS Comunidade Pankararu, em virtude de conflitos de interesses entre as lideranças Pankararu do Real Parque. Como pesquisador, tentei estabelecer um contato inicial com esta ONG, que se revelou infrutífero pelo fato do presidente da organização não demonstrar interesse em pesquisas com a comunidade Pankararu que não gerassem lucros financeiros para a Organização. Esta ONG, juntamente com Paula Morgado e João Cláudio de Sena, realizou o documentário "Do São Francisco ao Pinheiros", que trata do trânsito dos Pankararu entre a Terra Indígena no Nordeste e São Paulo, e realizou oficinas de vídeo com alguns jovens Pankararu, cujos vídeos foram lançados no Kinoforum.
} 
Segundo o seu atual estatuto, a Associação S.O.S. Comunidade Indígena Pankararu se constituiu em 29 de novembro de 1994 como uma entidade sem fins lucrativos com o objetivo de oferecer amparo e assistência a seus membros em diversas áreas como educação, alimentação, saúde, cultura, recreação e práticas esportivas. Cita como alguns de seus objetivos principais o fortalecimento e melhoria da qualidade das condições de vida das famílias indígenas por meio de projetos e atividades instrutivas, além de pretender colaborar com os poderes públicos constituídos, em especial a FUNAI, no sentido de proporcionar aos membros associados informações e atendimento em tudo que se refere à atuação e competência da FUNAI, que, em tese, é o órgão governamental responsável por dar assistência aos indígenas ${ }^{35}$.

O papel da Associação é voltado para os interesses sociais, com projetos que a comunidade solicita, por exemplo, documentos. Para documentar (a parte) visual e auditiva, como os cantos, as danças, a festa. A gente tem essa participação dentro da comunidade. A associação é um ponto de escuta e de referência (cf. depoimento de Dora Pankararu, liderança Pankararu ${ }^{36}$ ).

Segundo Fialho (2008), as relações entre os indígenas e o Estado e outras instâncias sociais e políticas marcadas pelo clientelismo e o poder tutelar não permitiram que os espaços de negociação pudessem contemplar a pluralidade étnica da sociedade brasileira e configurar a atuação dos indígenas como atores legítimos e autônomos. No entanto, a proliferação, a partir da década de 1980, das associações indígenas em todo o Brasil tem demonstrado uma nova forma de condução das políticas no plano das relações internas de cada sociedade indígena, assim como também tem apresentado novos contornos de um amplo campo de relações que envolvem os mais diversos agentes (Estado, ONGs, Empresas de Iniciativa Privada, Igreja).

A FUNAI, a FUNASA não reconheciam a comunidade Pankararu dentro da cidade de São Paulo. Então, a gente precisava ter uma forma organizada para poder se legitimar, documentar tudo dentro da comunidade como um setor

\footnotetext{
${ }^{35}$ É interessante observar que, em seu estatuto, a Associação estabeleça a definição de Associados Efetivos, que incluem os fundadores da Associação e membros da etnia Pankararu que estão associados, como também Associados Colaboradores, que seriam pessoas físicas ou jurídicas de outras etnias indígenas ou não-indígenas que prestem auxílio ou algum tipo de serviço à Associação. Isso implica dizer que o ingresso na Associação não está restrita apenas aos indígenas Pankararu, mas se estende também a membros de outras etnias indígenas e não-indígenas.

${ }^{36}$ Vídeo Eu venho do mundo (2008), de Edson Nakashima e Marcos Albuquerque.
} 
organizado mesmo (...) A gente precisava ter uma coisa chamada Estatuto para que as organizações federais públicas ou privadas tivessem também aí um respeito para trabalhar com os indígenas locais, porque a gente começou a buscar documentos. Eles começaram a cobrar papel. Então a gente teve que se enquadrar nesse sentido (cf. depoimento de Dora Pankararu ${ }^{37}$ )

Esse processo configura uma esfera pública de outro tipo, como bem descreve Burity:

“ $\{\ldots\}$ uma esfera pública plural - ou uma pluralidade de esferas públicas - que reduziu a centralidade do Estado e ampliou a noção de público através de uma incorporação, pela sociedade civil, de funções de provisão e controle (ainda que experimentais e circunscritas). Pode-se falar da constituição de uma esfera híbrida de cidadania. Híbrida por ser estatal e não-estatal. \{...\} Híbrida, ainda, por ser ideologicamente heterogênea, mesmo ambígua, em sua utilização da linguagem dos direitos e da participação, como alternativa, à força do dinheiro e do poder político tradicional” (Burity, 2002, p. 313 Apud Fialho, 2007, p. 19).

Segundo Lopes da Silva (1999), esse movimento de inserção na esfera pública mencionada por alguns dos indígenas realizou-se em um contexto histórico no qual se observa a constituição e consolidação maciça de organizações indígenas em virtude das possibilidades jurídicas oferecidas pela Constituição de 1988, que reconheceu a organização e participação políticas cada vez mais atuantes dos indígenas no cenário nacional. Em contrapartida, nota-se também o processo de enxugamento do Estado e a capacidade cada vez mais limitada de órgãos de assistência ao indígena, como a FUNAI, o que tem desencadeado um movimento crescente de projetos de autoria indígena em todo o país, formulados mediante parcerias das mais diversas com organizações não-governamentais, órgãos do Estado, universidades, fundos de pesquisa e outras instâncias. Todo esse processo ocorre em meio a um determinado grau de tensão entre conhecimentos tradicionais e ocidentais, entre políticas públicas e a própria organização político-social das aldeias, e também entre as tendências internacionais (como as que são determinadas por organismos como a ONU, a UNESCO, entre outros) e as estratégias e opções de vida adotadas pelas comunidades indígenas especificamente. Não se pode esquecer que as comunidades indígenas são afetadas

\footnotetext{
${ }^{37}$ Vídeo Eu venho do mundo (2008), de Edson Nakashima e Marcos Albuquerque.
} 
diretamente pelas transformações que ocorrem em nível regional ou mundial. Como resultado, "no plano local, registra-se a multiplicação dos atores em interação, a complexificação das relações sociais, políticas e econômicas e a ampliação do universo social indígena, com novas informações, novas alianças, novos parceiros, novas e diversificadas formas de organização e estratégias de construção e reconstrução simbólicas e identitárias" (Lopes da Silva, 1999, p. 166).

A criação das associações segue a tendência da estruturação deste mercado de projetos, segundo a qual as sociedades indígenas começaram a pautar suas reivindicações. Segundo Albert (2000), passou-se de uma etnicidade estritamente política (na virada dos anos 1980/90, com base em reivindicações territoriais, como a que envolveu e ainda tem envolvido os indígenas do Nordeste) para uma etnicidade de resultados, em que a prioridade passou a ser dada à afirmação identitária em busca de acesso ao "mercado dos projetos", inaugurado por novas políticas descentralizadas de desenvolvimento. No entanto, esta "etnicidade de resultados" não deixa de ser eminentemente política. Os resultados e os benefícios têm sido negociados no sentido de dar plasticidade às identidades indígenas, evidenciar as diferenças étnicas e de poder, visando o reconhecimento da cidadania (cf. Fialho, 2008). O fortalecimento da luta étnica passa pelo fortalecimento e institucionalização da politização da resistência indígena com o surgimento de entidades concretas, de corpos visíveis que encarnam essa política (Cervone, 1998, Apud Fialho, 2008).

Nós começamos a dançar o Toré, dançar os Praiás e a se identificar, depois da Associação. Porque a Associação, nós lutou para conseguir ela porque a FUNAI não queria atender nós como índio, porque eles acham que o índio só é índio na aldeia. Eu sempre falo: o japonês, o africano, o alemão, quando eles saem da área deles, eles não deixam de ser o que eles são. Igualmente os índios (cf. Bino Pankararu, liderança da comunidade ${ }^{38}$ )

Desse modo, muitos espaços passam a se constituir em busca da viabilização de um diálogo interétnico. $\mathrm{E}$ as sociedades indígenas têm passado a ocupar uma nova posição nas negociações que se travam em torno de seus direitos e da tentativa de efetivar sua autonomia, sendo capazes de se apropriar dos novos mecanismos, bem como de novas formas de mobilização que têm surgido em meio às relações

\footnotetext{
${ }^{38}$ Vídeo Eu venho do mundo (2008), de Edson Nakashima e Marcos Albuquerque.
} 
interculturais, permitindo, aos poucos, oferecer à sociedade brasileira elementos para uma atitude um pouco mais reflexiva sobre a sua identidade interétnica.

Em meio a essas mobilizações políticas, Albuquerque (2007) destaca os Praiás, como máscaras e vestimentas que representam os Encantados, como um elemento de destaque nas apresentações públicas dos Pankararu do Real Parque, em um contexto de inserção desses indígenas em dois âmbitos: o das artes étnicas e o dos direitos das populações indígenas.

Ao darem visibilidade à sua condição de índios e reivindicarem suas legitimidade pela apresentação pública dos Praiás, há uma organização social na comunidade que dialoga com a categoria tradição como antigo e novo, ortodoxia e heterodoxia, em dois grandes planos: a) como bem simbólico no mercado das artes étnicas da cidade de São Paulo, entre lutas pelo poder de monopólio deste campo, no sentido de Bourdieu (1989 e 2004); e b) na visibilidade da ação estatal, de órgãos públicos, Igreja (CIMI) e de ONG's pela concretização dos direitos indígenas e ampliação da democracia brasileira (Albuquerque, 2007, p. 78).

\section{Os caminhos da visibilidade}

A Associação S.O.S. Comunidade Indígena Pankararu realizou apresentações de Toré com os Praiás para o público, em diversas ocasiões. Estes são os eventos públicos destacados pela Associação em alguns de seus documentos:

- Setembro de 2004 - Rito de Passagem (Ideti), no Parque do Ibirapuera São Paulo;

- Outubro de 2005 - Rito de Passagem (Ideti), Rio de Janeiro;

- Abril de 2005 - Centro Cultural Banco do Brasil com a participação conjunto de Dj Tudo e Projeto Cru;

- Abril de 2007- $1^{\circ}$ Encontro de Cidades Latino-americanas sobre DST/Aids e População Indígena - Secretaria Municipal de Saúde - SP;

- Abril de 2007 - Brasilidades "Os donos da Terra", Associação dos Funcionários Públicos do Estado de São Paulo - AFEPESP;

- Maio de 2007 - Virada Cultural Municipal, Vale do Anhangabaú;

- Maio de 2007 - Virada Cultural Paulista, Bauru;

- Agosto de 2007 - Prêmio Culturas Indígenas 2006, Sesc Vila Mariana. 
Além disso, entre os meses de abril e maio, os Pankararu realizam anualmente apresentações no próprio bairro Real Parque, alternando-se entre a quadra de esportes do Projeto Casulo e a quadra da EMEF Alcântara, em que são convidados indígenas Pankararu de toda a cidade, além de outras etnias indígenas presentes em São Paulo. Estes encontros anuais se tornam momentos de confraternização e de encontro dos indígenas de São Paulo e também uma oportunidade de demonstrar a sua etnicidade à comunidade local como também à sociedade em geral. Ocasionalmente, realizam também apresentações em um pequeno terreno localizado entre os prédios do Cingapura localizados no Bairro Real Parque.

Aqui em São Paulo nós fazemos assim: às vezes alguém chega e convida a gente para fazer uma apresentação na escola, na igreja, a gente acerta um valor e vai. Inclusive em setembro nós fizemos uma apresentação aqui no Ibirapuera. A gente foi lá com um parente Xavante. Eles fizeram um evento lá. Tinham oito etnias de cada lugar. Muita gente acha que a nossa dança aqui tem diferença com a da aldeia. Mas não tem, é uma dança só, entendeu?... Foram quatro dias seguidos. Foi maravilhoso, só via o pessoal achar bonita a nossa cultura. Se abre um espacinho desse tamainho, já dá para matar um pouco da saudade. E as pessoas de fora que gostam de ver a coisa bem feitinha ficam emocionadas. Porque ou você se arrepia de medo ou de emoção (cf. Bino Pankararu, sobre a apresentação de Toré no evento Rito de Passagem, realizado em 2004, juntamente com outras etnias $^{39}$ )

Se, por um lado, as apresentações de Toré geram dividendos financeiros para os membros da comunidade, observamos também que, para os Pankararu, elas se tornam um momento de confraternização com as outras etnias presentes em São Paulo, uma oportunidade de manifestar suas tradições e suas manifestações culturais para a sociedade, mas também um instrumento político que permite afirmar a etnicidade do grupo na metrópole e de rememorar e reafirmar os laços afetivos com a Terra Indígena no Nordeste, demonstrando o caráter "multissignificativo" que o Toré apresenta.

Além disso, por meio de recursos disponibilizados pelo PAC (Programa de Ação

Cultural, 2007), a Associação SOS Comunidade Indígena Pankararu pode gravar um

\footnotetext{
${ }^{39}$ Relatório da Comissão Pró-Índio de São Paulo, 2005.
} 
CD com as músicas tradicionais Pankararu, os toantes e os torés, nas festas da comunidade realizadas no ano de 2007.

\section{A Virada Cultural}

Com relação a uma política de visibilidade, a participação dos Pankararu na Virada Cultural de 2007, evento de cultura e entretenimento patrocinado pela Prefeitura de São Paulo e realizado em um período de 24 horas ininterruptas (iniciado às $18 \mathrm{~h}$ do dia 5 de maio e finalizado às $18 \mathrm{~h}$ do dia 6 de maio) também merece destaque. A apresentação do Toré Pankararu foi realizada às $8 \mathrm{~h} 30$ do dia seis de maio no Palco de Dança - Anhangabaú, em meio a apresentações de balé clássico e danças afrobrasileiras, em um palco colocado no centro da cidade de São Paulo. O momento de apresentação dos Pankararu foi uma oportunidade para Bino Pankararu, também cantador dos toantes e torés, falar em curto mas significativo espaço de tempo a respeito das condições e dos desafios enfrentados pelo grupo étnico, bem como da discriminação que sofrem na cidade de São Paulo, para um público mais amplo ali presente. Em uma matéria escrita a respeito da Virada Cultural, no Jornal da Tarde do dia 7 de maio do mesmo ano, houve uma menção à apresentação de Toré dos Pankararu:

Quando muitos ainda se recuperavam da folia do sábado, os índios Pancararu (sic) apresentaram o Toré, ritual ao mesmo tempo religioso e profano, por volta das 8 h30 no Palco do Anhangabaú. Além de desabafar sobre a condição sofrida da tribo, eles emocionaram as pessoas que estavam no local - até mesmo as que conferiram a performance por engano. 'Eu vim para o lugar errado, queria ir para o show do Pato $\mathrm{Fu}$, mas acabei amando o que vi. Conheci algo novo, me emocionei com a batida, com as vozes dos índios', contou a estudante Juliana Rodrigues, de 20 anos (Jornal da Tarde, 2007, p. 6). 


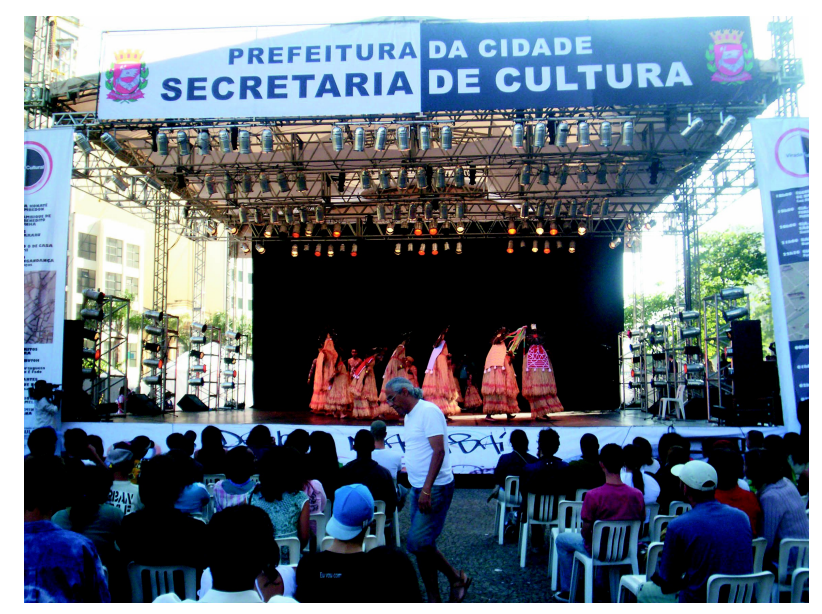

Nesse sentido, podemos observar que, em meio a tantos eventos artísticos apresentados na Virada Cultural, a mídia impressa deu relativo destaque à apresentação indígena, qualificando-a como ritual religioso e profano, que emocionou e conscientizou o público presente a respeito das condições vividas pelo grupo étnico. Assim observamos que o Toré e os Praiás têm se demonstrado um poderoso recurso para lhes dar visibilidade, contribuindo para a efetivação dos direitos indígenas, como podemos observar no depoimento de Bino Pankararu:

Se nós tivéssemos uma terra para nós fazer nossos terreiros e tradições, aí nós fazia tanto essa dança, como trazia o Menino do Rancho, a Corrida do Umbu. Para minha alegria, o Pajé liberou trazer só 10 roupas (os Praiás) onde, na minha aldeia, temos mais de 100. (cf. Bino Pankararu ${ }^{40}$ ).

Este depoimento contraditório demonstra alguns elementos importantes para a constituição da etnicidade Pankararu. Faz menção, em um primeiro momento, ao fato de que de os Praiás terem sido liberados pelo Pajé no Nordeste para serem trazidos para São Paulo, o que é motivo de comemoração, mas por outro lado, o pequeno número de roupas (apenas dez) em relação ao que estão no Nordeste, traz também um lamento e um desejo de que mais Praiás poderiam ter sido trazidos. A esse respeito, é interessante que observemos os detalhes de como essa "transposição" é feita de acordo com Dora Pankararu:

O que acontece em São Paulo é o que acontece na Aldeia (referindo-se às danças). Só que a diferença é que lá é uma reserva, não é um cimento, não é

\footnotetext{
${ }^{40}$ Vídeo de divulgação da Agenda Indígena (2007).
} 
improvisado (...) Essas pessoas que dançam são chamadas de Praiá. A roupa é feita de croá, um material semelhante ao sisal. Esse tecido (...) na cabeça a gente chama de Cinta. Identifica cada Encantado da entidade religiosa. Cada um tem seu nome, tem seu trabalho dentro da entidade como religião espiritual para gente, nosso povo. (cf. depoimento de Dora Pankararu ${ }^{41}$ ).

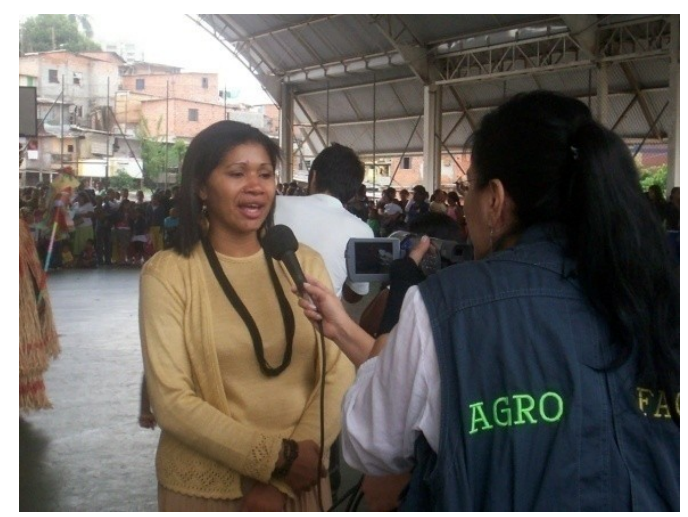

Temos nesse depoimento uma pequena descrição do Praiá, segundo o qual o tecido que cobre a parte da cabeça da indumentária, chamada de Cinta, tem como função identificar o Encantado ao qual o Praiá pertence, sendo que cada Encantado tem o seu próprio nome e uma determinada forma de atuação dentro da comunidade. Segundo Matta (2007), em 1994, ano da criação da primeira associação dos Pankararu, havia somente um Praiá em São Paulo, chamado de "Cinta Vermelha", "levantado" sob a supervisão de Frederico Marciolino de Barros, um dos fundadores da Associação. Foi somente no ano de 2000 que mais dez Praiás foram levantados sob a supervisão de Bino, atual presidente da Associação. Destes dez Praiás, seis foram feitos na Terra Indígena, enquanto que os outros quatro foram confeccionados em São Paulo com fibras de caroá coletadas na aldeia e com a expressa autorização dos seus zeladores no Brejo dos Padres, pois o "levantamento" só poderia ser realizado mediante a anuência de seus responsáveis, o que explica o contentamento de Bino Pankararu. Segundo Matta (2007), eles pertenceriam a um mesmo “pai”, embora não pertencessem a um terreiro específico. Observe-se, ainda, de acordo com Dora, que os Praiás que estão em São Paulo possuem a mesma força dos que estão na Aldeia, sendo considerados fundamentais portanto o zelo religioso e o uso respeitoso deles pela comunidade Pankararu de São Paulo. Em uma das entrevistas realizadas com Bino, ele demonstrou todo um cuidado ritualístico em relação aos Praiás que estão sob sua responsabilidade,

\footnotetext{
${ }^{41}$ Vídeo de divulgação da Agenda Indígena (2007).
} 
guardando-os em um quarto da Associação e merecendo um cuidado ainda maior nos momentos anteriores às apresentações, que eles chamam de "trabalho". Os próprios Pankararu que irão vestir os Praiás devem estar "puros", ou seja, não devem ter mantido relações sexuais e nem tomado bebida alcoólica no período de preparação, sob o risco de sofrerem um "castigo" por parte dos Encantados pela falta de zelo.

Em seu depoimento, Bino faz menção às danças e comenta que diversos rituais que são realizados na Terra Indígena no Nordeste, como a Flechada do Umbu, o Menino do Rancho e a Festa do Cansanção, não poderiam ser feitos em São Paulo por falta de espaço físico apropriado. Essa fala nos conduz a outro aspecto considerado fundamental pela comunidade Pankararu - o desejo de ter um espaço próprio, um “terreiro", um espaço sagrado para a realização de suas festas, cerimônias, rituais e também um local de plantio de suas ervas tradicionais, assim como de uma agricultura de subsistência. Nesse sentido, fica patente entre os Pankararu o desejo de reterritorialização étnica em São Paulo, transformando-se efetivamente em um "enxame", do mesmo modo que ocorreu no município de Coronel Murta, em Minas Gerais, onde Pankararu migrados do Nordeste adquiriram uma área por intermédio da atuação de setores da Igreja Católica ${ }^{42}$.

\title{
A busca por uma reterritorialização étnica
}

A reivindicação por uma terra própria em São Paulo é uma constante em diversas falas em público dos Pankararu, como observamos abaixo:

\begin{abstract}
Nós precisamos de terra, onde pudéssemos plantar. Se nós não tivéssemos essa cultura, não teríamos reconhecimento. A FUNAI quer que a gente fique na aldeia para matar como piolho na unha. Temos de ter nosso terreiro próprio. Isso aqui devia ser de terra (em relação à quadra do Projeto Casulo) (cf. Bino Pankararu ${ }^{43}$ ).
\end{abstract}

A menção de que o local de realização das apresentações Pankararu deveria ser na terra e não no concreto da quadra fica bastante evidente nesta fala. Também observamos a menção à FUNAI, órgão ao qual os indígenas de São Paulo direcionam as

\footnotetext{
${ }^{42}$ Atualmente, um grupo familiar de 25 indígenas Pankararu vive no município de Coronel Murta, Vale do Jequitinhonha, em uma área de 60 hectares, doada pela Diocese de Araçuaí.

${ }^{43}$ Entrevista realizada no dia 29 de junho de 2007 para a Agência Afropress, no dia de uma apresentação de Toré no ginásio de esportes do Projeto Casulo no Real Parque para a Agenda Indígena. A alusão à terra foi pelo fato da apresentação estar sendo realizada no cimento da quadra.
} 
suas mais veementes críticas e reclamações, visto que seria ela que deveria reconhecer e dar maior assistência aos indígenas, mas que nada faz nesse sentido por ter uma política de atendimento estritamente direcionada aos indígenas que estão em aldeias. Oferecer escassa assistência aos indígenas na cidade é parte de uma estratégia velada de nãocompromisso por parte do órgão indigenista, uma vez que a concepção geral que reina nas instituições é a de que só é considerado indígena aquele que estiver na aldeia, reforçando então um estereótipo de indígena que apenas contribui para que haja preconceitos, discriminações ou mesmo exclusões em relação a eles na metrópole. A seguir, temos um depoimento de um jovem indígena Pankararu a respeito da apresentação de Toré na EMEF Alcântara:

\section{Resistência e perseverança}

Neste dia 07/06/2008, provamos mais uma vez para a sociedade e comunidade local, que nesta selva de pedra têm indígenas, por mais que alguns deles não nos queiram ver, mas sim existimos aqui.

Quebramos os estereótipos da visão de muitos, que não ver agente com olhares de guerreiros e resistentes. Não nos importam o que pensam, mais sim nossas atitudes em relação a nossa essência e valores.

Nós indígenas Pankararu, vivemos na periferia do bairro do Morumbi (Colinas verdes), há mais 5 (décadas) onde se localizam os mais luxuosos edifícios da classe media alta.

Por mais que não estejamos na nossa Aldeia Brejo dos Padres, de origem nunca deixamos de ser índios, porque independente os estejamos vamos sempre ser indígenas e honraremos cada vez mais nossas raízes.

"Tolo é o homem que nega suas origem, esquecendo de sua cultural tradicional, apagando suas raízes. Isso é contribuir com o genocídio e etnocídio.”

Na escola E.M.E.F. José de Alcântara Machado Filho, onde a maioria dos indígenas Pankararu de São Paulo estudou, fazemos da quadra de esporte o terreiro para dançar os toantes e toré.

Mesmo não sendo nosso sagrado terreiro deu muito orgulho e emoção em ver nossos encantados flutuarem naquela hora, e na hora do toré os parentes baterem o pé com fé no chão. Não podia faltar a garapa de rapadura, umbuzada, comida típica (carne de boi, arroz e farinha de mandioca).

(...) 


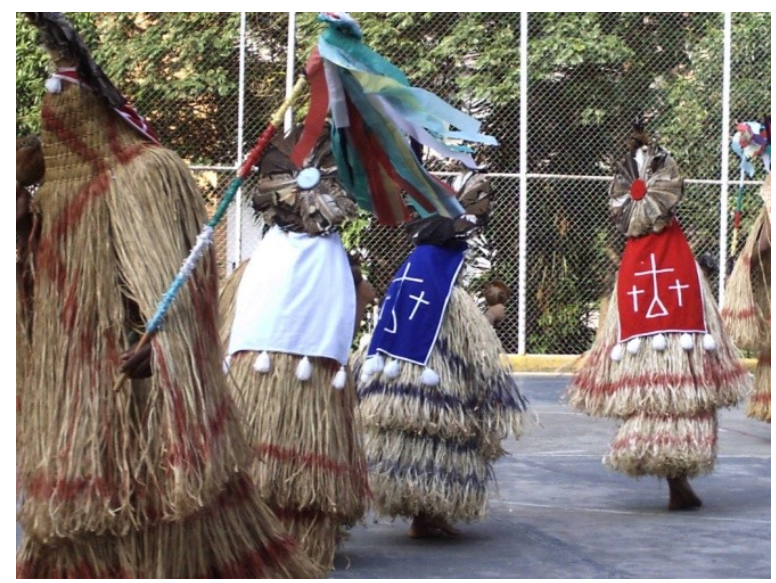

Crédito: Marcos Albuquerque

Este texto foi escrito por um jovem membro da comunidade Pankararu no site indiosonline, apresentando fotografias com cenas dos Pankararu realizando o Toré na EMEF Alcântara em junho de 2008. Um depoimento bastante ilustrativo, que traz à tona diversos elementos que podem ser discutidos. O primeiro é a menção de que os Pankararu moram na "periferia" do bairro nobre do Morumbi, ou, como é denominado por alguns de "bolsão de pobreza" em meio aos edifícios de alto padrão do bairro, ficando até evidente a ironia em relação ao nome indígena Morumbi, que vem do tupiguarani, e significa "Colinas Verdes". Um comentário que nos chamou a atenção foi que, por mais que os indígenas não estejam em sua aldeia de origem, eles nunca deixam de ser indígenas. Essa é uma afirmação recorrente entre os Pankararu nas lides com os órgãos públicos que deveriam prestar assistência aos indígenas na cidade.

Mediante diversas solicitações por uma terra indígena no Estado de São Paulo por parte da comunidade Pankararu aos órgãos públicos, o então presidente da FUNAI Glenio da Costa Alvarez assinou a portaria $n^{\circ}$ 921/PRES, de 4 de setembro de 2000, no qual criava um Grupo de Trabalho (GT) tendo como prerrogativas os seguintes itens:

- "a existência de um expressivo contingente de índios Pankararu, originários do sertão de Pernambuco, estabelecidos a partir da década de 50 na Favela Real Parque, São Paulo, Capital;

\footnotetext{
${ }^{44}$ Texto retirado do site indiosonline: http://www.indiosonline.org.br/blogs/index.php? $\mathrm{blog}=11 \& \mathrm{p}=2808 \&$ more $=1 \& \mathrm{c}=1 \& \mathrm{tb}=1 \& \mathrm{pb}=1 \#$ more 2808 .
} 
- a precariedade das informações disponíveis sobre o histórico do êxodo Pankararu em direção ao Estado de São Paulo, e por conseqüência quais os projetos do povo Pankararu;

- a crescente reivindicação da comunidade indígena quanto ao seu assentamento definitivo no Estado de São Paulo, envolvendo negociação com diversas instâncias do poder público local;

- e os aspectos de natureza antropológica e as relações desse grupo indígena com outras etnias presentes no Estado de São Paulo, e em especial os impactos provenientes de possível proximidade com os grupos Guarani" (FUNAI, 2000, p. 9)

O Grupo de Trabalho (GT) foi composto por um Técnico do Indigenismo (Moacir Santos); uma antropóloga (Juracilda Veiga, contratada pela UNESCO/FUNAI) e um engenheiro agrônomo (Paulo Spyer, contratado pela UNESCO/FUNAI) para atender a esta demanda. O objetivo deste Grupo de Trabalho era realizar "in loco" um estudo entre os dias 18 e 21 de setembro de 2000, "com a finalidade de fornecer parâmetros/propostas à Presidência da FUNAI quanto à definiç̧ão das ações necessárias para o encaminhamento de uma política de apoio ao povo Pankararu que contemple tanto o aspecto fundiário, quanto suas relações sociais e de sobrevivência econômica, no menor tempo possível" (FUNAI, 2000, p. 9). Segundo Lima (2007), o trabalho de campo, realizado entre os dias 18 e 29 de setembro, possibilitou ao GT verificar que os Pankararu, embora espalhados em diversas localidades da Grande São Paulo, formavam de fato uma comunidade.

O GT esteve em São Paulo ente os dias 18 a 29 de setembro onde visitamos principalmente os Pankararu que estão vivendo espalhados pela periferia de São Paulo: Capão Redondo, Campo Limpo e outras vilas menores na mesma região. Cadastramos 57 famílias Pankararu e pudemos constatar portanto o total de 900 Pankararu. (FUNAI, s/p).

Os membros do GT observaram que 140 das 370 famílias (cerca de 40\% do total) manifestavam o desejo de viver em uma terra indígena a ser constituída em São Paulo, sendo estas as mais carentes e as menos adaptadas à vida na metrópole, principalmente em razão da dificuldade de se obter emprego ou trabalho regular e devido à violência urbana, propondo, para isso, a criação de uma Terra Indígena com 
área de aproximadamente 2.000 hectares. Analisemos o texto que resultou do contato do Grupo de Trabalho com as demandas da comunidade Pankararu em São Paulo no ano de 2000:

Os Pankararu de São Paulo são cerca de 900 pessoas. Segundo levantamento da Associação Pankararu, 370 famílias. Dessas nem todas iriam para uma terra. Mas com certeza 40\% deles iriam de imediato caso existisse um território, ou seja, 140 famílias aproximadamente. Eles solicitam uma terra de aproximadamente 2000 ha. Essa terra deveria ser de boa fertilidade, possuir água e se possível uma vegetação natural. Os Pankararu consideram que uma área agricultável seria a condição para a recomposição cultural da unidade social Pankararu. Eles têm um planejamento do que fariam nessa terra: plantação de mandioca e construção de casa de farinha conforme o sistema de produção dos Pankararu. Plantação de milho e feijão. E plantio de côco para fins comerciais. Querem formar uma cooperativa e possuem uma visão de que produtos orgânicos têm boa demanda comercial e vêem que por esse caminho conseguiriam facilmente financiamento. E pensariam em ter uma comercialização direta com o CEAGESP. Outra alternativa seria uma cooperativa de serviços gerais. Uma das primeiras coisas que plantariam seriam cana e cansanção para os rituais (FUNAI, s/p).

De acordo com Lima (2007), o GT, em seu relatório de averiguação, destacou que os índios denominados de "desaldeados" constituem um grave e crescente problema que coloca em xeque a política do órgão indigenista oficial em todo o país. Em relação aos Pankararu, dois aspectos mereceriam destaque: o direito à assistência diferenciada na saúde e educação e a reivindicação da terra no estado de São Paulo. É interessante verificar que o GT destaca uma lacuna existente na atual legislação que dificulta a resolução da questão dos direitos a uma assistência diferenciada. Tomando como reflexão o artigo 231 da constituição, os membros do GT destacaram que o enfoque da legislação vincula a natureza étnica diferenciada e, conseqüentemente, os direitos atrelados a esta etnicidade, à necessidade de um determinado grupo étnico possuir um território definido.

Os dispositivos posteriores à promulgação da atual Constituição Federal, que regulamentam a assistência às comunidades indígenas, traz inserida a condição de 
'territorialização', a despeito da dinâmica do processo de socialização dessas comunidades (SANTOS et alli, 2000, p. 12 Apud Lima, 2007).

Existe, portanto, uma dificuldade, por parte dos órgãos públicos, de pensar a identidade étnica sem que ela esteja vinculada à territorialidade. Em decorrência disso, a reivindicação por direitos e terras no estado de São Paulo é vista em geral como imprópria pelos órgãos institucionais. No entanto, mesmo que, numa situação hipotética, as questões fundiárias no território Pankararu sejam resolvidas e que condições para a sua subsistência sejam oferecidas, isto não implicará na garantia de retorno de grupos Pankararu a seu território no Nordeste. Parece-nos bem provável que o fluxo entre São Paulo e Pernambuco permaneça em razão das condições já estabelecidas e os direitos já consolidados pelos Pankararu em São Paulo. Cabe lembrar, ainda, que os Pankararu também adquiriram maior visibilidade no cenário nacional e consolidaram muitos de seus direitos justamente por causa da comunidade estabelecida em São Paulo. A conclusão do GT, em virtude de todas estas colocações é de que a reivindicação de um território Pankararu na metrópole paulista é justa. Assim como diz a Portaria da FUNAI, a razão da criação do GT foi motivada para se estabelecer "ações necessárias para o encaminhamento de uma política de apoio ao povo Pankararu que contemple tanto o aspecto fundiário, quanto suas relações sociais e de sobrevivência econômica, no menor tempo possível" (FUNAI, 2000, p. 9). No entanto, até a presente data, a delimitação de um território indígena para os Pankararu em São Paulo não foi estabelecida (cf. Lima, 2007) ${ }^{45}$.

\section{Ouvindo a voz dos que não têm vez?}

Em uma iniciativa da Comissão de Direitos Humanos da Assembléia Legislativa de São Paulo, juntamente com a Comissão Pró-Índio (CPI-SP), o CIMI (Conselho Indigenista Missionário), PUC-São Paulo e a Universidade Sagrado Coração de Jesus de Bauru, foram realizadas audiências públicas que foram assim designadas: "Vamos ouvir a voz dos que não têm vez". Elas tiveram como objetivo dar ouvidos às demandas das lideranças das etnias indígenas presentes em São Paulo e propiciar um diálogo

\footnotetext{
${ }^{45}$ Segundo depoimento de Bino Pankararu, a proposta de uma terra indígena para os Pankararu não foi concretizada porque, na área onde a FUNAI cogitava estabelecer os Pankararu e que havia sido doada por seu proprietário, haveria a necessidade de expulsar os moradores que nele habitavam. Em vista disso, as lideranças decidiram optar por recusar o terreno doado.
} 
destas com os órgãos governamentais, de modo que fosse possível delinear as possibilidades de intervenção da Assembléia Legislativa como garantia e modo de consolidação dos direitos indígenas, além de proporcionar subsídios para a atuação dos deputados da Comissão de Direitos Humanos da Assembléia Legislativa sobre a questão. Assim, seis audiências públicas foram realizadas entre fevereiro e junho de 2002 em localidades diferentes de modo a garantir a participação de representantes de todas as terras indígenas localizadas em São Paulo. Essas audiências possibilitaram um diagnóstico atualizado e representativo das demandas das comunidades indígenas em São Paulo. As discussões realizadas nas audiências foram registradas no Relatório "Vamos ouvir a voz dos que não têm vez", de Junho de 2002, sob coordenação do deputado Renato Simões.

Seria importante salientar as discussões realizadas no âmbito do Legislativo, em relação às condições dos indígenas Pankararu em São Paulo. Vejamos o diagnóstico relativo às condições dos Pankararu, no item "Principais problemas", tal como fora registrado em documento da Assembléia:

Originários de Tacaratu (PE) reivindicam uma área rural no Estado de São Paulo. Falta de identificação de uma terra para assentamento da comunidade e reconhecimento pela FUNAI, e repasse para a comunidade de área de Miracatu, com 12.000 ha, doada pelo proprietário. Distância do escritório da FUNAI da maioria da população indígena no Estado de São Paulo. Problemas inerentes à realidade das favelas nas grandes cidades: droga, violência, desemprego, assassinato (desde 1980 doze Pankararu foram assassinados). Ausência de projetos para geração de emprego e renda, de apoio para o funcionamento da associação e de assistência jurídica. Falta de ajuda para estudantes que estão na PUC-SP e no Cursinho da Poli (Assembléia Legislativa de São Paulo, 2002, p. 29).

Ainda na primeira parte do Relatório denominada "Recomendações aos Poderes Públicos", no item "Assegura o direito à terra", há um sub-item que trata do levantamento de terras para a reaglutinação dos Pankararu e que coloca como uma das prioridades do trabalho de arrecadação de terras para os povos indígenas de São Paulo a identificação de terra suficiente para agregar as comunidades Pankararu dispersas pelos bairros da capital e de municípios da Grande São Paulo. Como recomendação, solicitase ao Itesp (Fundação Instituto de Terras do Estado de São Paulo) que inicie diálogos 
com a FUNAI para a vistoria de uma área particular oferecida pelo proprietário para os Pankararu, na região dos Municípios de Juquitiba e Miracatu.

Para uma compreensão da problemática da terra, observamos o depoimento de Dimas Pankararu, até então presidente da Associação SOS Pankararu:

O nosso maior problema é a questão da terra. A terra já foi doada para nós. Agora, o problema está na FUNAI. É só ter um pouco de boa vontade, porque os documentos já foram todos reconhecidos, já está tudo regularizado. Agora só falta a FUNAI entrar com a parte da demarcação e fazer a medição da área. Eles vão demarcar, fazer o reconhecimento, e a área vai ser registrada com um novo nome: Aldeia Indígena Pankararu. A comunidade está ansiosa porque tem alguns projetos que até agora não está servindo para nós Pankararu devido à gente não ter uma área. (...) A gente espera logo ter a terra para termos o nosso direito garantido, porque a terra, para nós hoje é o fundamental. Hoje, sem a terra nós não somos ninguém e somos muito aqui na capital, pois é insuficiente para todos viverem a nossa terra em Pernambuco. (...) A gente espera que agora, com essa oportunidade, fortaleça e dê esse sonho para nós, porque nós já estamos sonhando há mais de seis anos quando nós formamos a nossa associação (Assembléia Legislativa de São Paulo, 2002, p. 42).

Dimas ainda relatou em seu depoimento a necessidade de uma escola diferenciada e, embora a FUNASA estivesse oferecendo um atendimento adequado, era necessário ainda um hospital de referência. "Então, a gente pede a colaboração dos senhores deputados e demais lideranças para que dêem apoio para nós, na saúde e na educação (...)" (Assembléia Legislativa de São Paulo, 2002, p. 42).

Podemos notar que as reivindicações das lideranças Pankararu têm se encaminhado para três áreas específicas: a terra (em maior grau), saúde e educação. Cabe ressaltar que a questão de uma educação diferenciada passou também a assumir uma importância capital nas reivindicações dos indígenas, que têm se conscientizado que, mesmo morando em cidades, necessitam de um ensino que esteja atento às peculiaridades do contexto sócio-cultural no qual vivem.

Uma iniciativa surgida com as audiências por parte do Legislativo foi o Projeto de Lei $n^{o}$ 409/2002, do deputado Renato Simões, que criou o Conselho Estadual dos Povos Indígenas de São Paulo (Cepisp). De acordo com este Projeto, o Cepisp se 
tornaria um órgão colegiado, de caráter deliberativo, cujo objetivo seria promover, em âmbito estadual, políticas públicas que busquem contemplar as comunidades indígenas do Estado de São Paulo. Este órgão que aparentava ser uma importante iniciativa e que permitiria um protagonismo indígena na promoção de políticas públicas, em realidade, foi instituido com base em uma estrutura de funcionamento que coloca as decisões praticamente nas mãos de não-indígenas e de representantes do governo. Observamos que as iniciativas acabam por ser reduzidas novamente a uma atuação pouco efetiva, revelando novamente a estratégia dos órgãos governamentais de não realizar alterações profundas na política de atuação aos indígenas. Iniciando as suas atuações desde 2004, as iniciativas do Cepisp têm se restringido à formação de Grupos de Trabalho (GTs), dentre eles o GT de Educação e o GT da Terra, cujos integrantes realizaram reuniões em 2006 com a FUNAI e com a Secretaria de Patrimônio da União, mas que têm apresentado poucos resultados efetivos, o que tem sido bastante criticado pelos indígenas. No III Encontro de Formação e Articulação Indígena, promovido pela Pastoral Indigenista da Arquidiocese de São Paulo e o Cimi (Conselho Indigenista Missionário) de São Paulo, realizado nos dias 18 e 19 de novembro de 2006, Bino Pankararu assim descreve em tom de desabafo a atuação do Cepisp e de outros órgãos: "Praticamente até agora o que temos é promessa, e quem vive de promessa é santo. A FUNAI só lembra dos índios em duas ocasiões: na hora de buscar votos para eleições e quando vem dinheiro do exterior para investir nos índios" (Cimi-Grande São Paulo, 2007, p. 12).

Podemos perceber nesse depoimento a visão aguçada que a liderança Pankararu tem a respeito do oportunismo dos políticos que buscam apenas se promover com a causa indígena e que não concretizam as promessas que já foram feitas em face das reivindicações realizadas. A alternância de poder político e as lutas políticas podem influenciar negativamente na afirmação étnica das novas gerações Pankararu.

\section{A Agenda Indígena}

Em termos da política de etnicidade realizada pelos indígenas de São Paulo, cabe citar a Agenda Indígena, realizada entre os dias 13 e 29 de abril de 2007, evento em que 
as etnias indígenas presentes em São Paulo se reuniram, como uma iniciativa da Comissão Intersecretarial de Monitoramento e Gestão da Diversidade (CIMDiversidade da Secretaria do Trabalho do Município) e Comissão de Indígenas. Nessa semana, ocorreram palestras, debates e manifestações culturais em vários pontos da cidade e também a elaboração de dez propostas que tinham como intuito serem transformadas em políticas públicas. Tais propostas foram lidas na língua Baniwa pelo indígena e estudante de Direito Eurico Sena Baniwa (Surisawa) para o Secretário Municipal do Trabalho, Geraldo Vinholi, no dia 19 de abril. No dia 29 de abril, foram lidas para o público que esteve presente nas apresentações de danças indígenas realizadas na quadra da ONG Projeto Casulo, no Real Parque, momento em que o Toré dos Pankararu se constituiu em um momento catalisador de todos os eventos. A seguir transcrevemos um trecho deste documento:

\section{Agenda Indígena de São Paulo}

Os Povos Indígenas radicados na Cidade de S. Paulo, reunidos na Agenda Indígena/2007, iniciativa da Secretaria do Trabalho do Município, por intermédio da Comissão Intersecretarial de Monitoramento e Gestão da Diversidade (CIMDiversidade), e Comissão de Indígenas, tornam públicas as proposições abaixo que esperam ver transformadas em políticas públicas na Cidade de S. Paulo.

1 - Respeito à condição de cidadãos aos membros de todas as etnias e povos indígenas, que vivem fora de suas aldeias, no meio urbano, buscando a sensibilização de acadêmicos, mundo empresarial, educadores e gestores públicos para a importância e necessidade de preservação de suas identidades culturais;

2 - Participação das nações indígenas radicadas em São Paulo em todas as atividades e manifestações culturais da cidade, como por exemplo, a Virada Cultural de São Paulo;

3 - Criação de canais de acesso com a Fundação Nacional de Saúde (FUNASA), órgão do Ministério da Saúde do Governo Federal, e Secretaria Municipal de Saúde, visando à adoção de políticas públicas com foco na saúde indígena, respeitando suas tradições culturais;

4 - Adoção de medidas que promovam o desenvolvimento e a capacitação profissional nos Centros de Educação e Cultura Indígena (CECIs) existentes na capital paulista; 
5 - Promoção e formação de professores da rede de ensino municipal, visando à inserção da temática da cultura e história indígenas em sala de aula;

6 - Promoção de uma campanha de sensibilização para os Direitos Indígenas junto às Subprefeituras, Secretarias, Coordenadorias, Comissões e Autarquias, bem como aos gestores sobre a necessidade de adoção de políticas públicas para a população indígena, que vive em aldeia ou não, da cidade de São Paulo;

7 - Promoção de um Censo Demográfico das populações indígenas radicadas na cidade de São Paulo, buscando o conhecimento de suas reivindicações e demandas;

8 - Criação do Centro de Referência Indígena na cidade de São Paulo para geração de trabalho e renda, que funcione como ponto de escoamento da produção artesanal indígena, difusão e promoção das culturas indigenas, bem como a capacitação dos profissionais envolvidos;

9 - Inserção de Indígenas como beneficiários dos programas da Secretaria do Trabalho, como Pró-Jovem, Capacita Sampa, São Paulo Inclui, São Paulo Confia (Microcrédito) entre outros;

10 - Fortalecimento da Comissão de Indígenas, co-promotora da Agenda Indígena de São Paulo, como espaço de organização, mobilização e interlocução junto ao Poder Público, dos Povos Indígenas radicados na capital paulista.

São Paulo, 19 de abril de 2007

Comissão de Indígenas de São Paulo.

O objetivo dessas propostas, segundo o vídeo de divulgação da Agenda Indígena de São Paulo (2007), foi buscar romper o silêncio e diminuir o preconceito em relação aos indígenas nas grandes cidades e possibilitar a manutenção de uma identidade cultural indígena. Seria interessante realizar uma análise das propostas e reivindicações pelo fato de constituir um dos primeiros documentos reivindicatórios realizados em conjunto por todas as etnias presentes na cidade de São Paulo, e também um indicativo das demandas sociais presentes nas comunidades indígenas em São Paulo.

Identificamos nessas proposições a solicitação de um censo que identifique quem e quantos são os indígenas na cidade de São Paulo. Com base nisso, deseja-se uma mobilização dos órgãos governamentais em torno dos direitos indígenas, o que poderia resultar em políticas públicas que proporcionem atendimento diferenciado aos indígenas em setores como saúde, emprego, cultura e educação, tendo sempre como foco a especificidade de suas culturas e tradições. Podemos destacar os itens 5 e 8 , que 
tratam diretamente da questão da educação diferenciada. No item 5, como um indicativo de que os indígenas da cidade têm voltado suas atenções para a questão educacional, reivindica-se melhor formação para os professores da rede de ensino municipal, com o intuito de inserir a temática da cultura e história indígenas nas salas de aula, decorrente do fato de que a temática indígena não vem sendo abordada, e quando isso ocorre, é realizada de forma bastante precária. No item 8 , há também a reivindicação de um Centro de Referência Indígena na cidade de São Paulo para geração de trabalho e renda, capacitação de profissionais indígenas e um local no qual as crianças indígenas poderiam ter contato com a história e cultura de suas etnias. Nesse sentido, podemos perceber que os indígenas da cidade também reconhecem que precisam de um centro ou um local no qual seja possível realizar a transmissão dos saberes indígenas, uma vez que o fato de morarem em uma cidade grande contribui para a dispersão da comunidade.

Em suma, solicita-se que os órgãos do governo tratem os indígenas na cidade como cidadãos, o que implica dizer que eles possuem direitos como todos os outros habitantes de São Paulo, ao mesmo tempo em que se deve dar uma atenção especial à condição dos indígenas como detentores de direitos diferenciados, mas que estão lhes sendo negados pelo fato de não estarem presentes em terras consideradas tradicionais. Assim, a questão da visibilidade perante a sociedade e os órgãos públicos se torna uma preocupação constante por parte destes grupos indigenas, mas que também irá demandar uma constante conceituação do que é ser indígena tanto pelos indivíduos e grupos que apresentam estas demandas, como também pelos organismos responsáveis pelo atendimento de tais comunidades. Fica assim evidenciada a relação paradoxal entre uma reivindicação universal pela igualdade de direitos e a garantia do direito particular à diferença dos indígenas, que se vê acentuada pelo fato destes habitarem em uma grande metrópole.

Embora a iniciativa da Agenda Indígena tenha partido de um órgão do próprio Município, observamos que praticamente todas as propostas ficaram somente na intenção de se tornarem políticas públicas, visto que não foram concretizadas até o presente momento - uma demonstração, portanto, da dificuldade das instâncias governamentais em viabilizar uma assistência digna aos indígenas da cidade.

De um modo geral, observa-se a dificuldade com que o poder público trata da questão indígena, em especial quando os indígenas estão lotados na própria região metropolitana de São Paulo. Verifica-se uma atitude ambivalente do poder público em 
relação a esta questão, pois se observam iniciativas isoladas por parte de determinados órgãos e repartições do governo com o intuito de concretizar políticas públicas que possam prestar uma melhor assistência aos indígenas, enquanto que se observa, ao mesmo tempo, a inoperância de outras instituições governamentais para que estas mesmas políticas requisitadas sejam viabilizadas. O resultado prático dessa atuação ambivalente é que as políticas públicas acabam por ficar somente no papel e na intenção, deixando o atendimento aos indígenas à deriva.

\section{Direitos indígenas diferenciados}

De acordo com Albuquerque e Nakashima (2008), podemos caracterizar um indígena pela sua ascendência e, nesse sentido, faz sentido que afirmemos que um indígena pode ser assim caracterizado por pertencer a uma sociedade indígena. Quando falamos em sociedade indígena estamos falando de toda aquela coletividade que se distingue da sociedade nacional por sua história, ou seja, que se reivindica como descendente de uma população nativa que habitava o território que hoje é o Brasil antes da chegada de Cabral ao Brasil no ano de 1500 (ou seja, uma população pré-cabralina e pré-colombiana).

Com raras exceções, todos os países do chamado terceiro mundo foram construídos por intermédio da guerra e o extermínio dos povos que habitavam estes territórios anteriormente à chegada do não-indígenas. Todo e qualquer indígena é descendente direto desse contato violento com as populações exógenas, trazendo consigo essa história comum e diferente, portanto, da dos não-indígenas. O Brasil reconhece que todo indígena hoje deve ser recompensado por causa desta violência, e é por isso que seguindo as iniciativas dos países que carregam essa história de opressão aos povos indígenas, o país passou a adotar leis que garantem aos mesmos recompensas a partir de uma legislação específica para eles. Conforme salienta Vaz Filho: “(...) o discurso da indianidade carrega consigo as denúncias das injustiças históricas cometidas contra os indígenas e fundamenta e legitima as reivindicações dos direitos humanos específicos devido à sua condição de indígenas" (Vaz Filho, 2006, p. 2).

Pela legislação brasileira, os indígenas são considerados cidadãos como todos os outros, com todos os direitos e deveres garantidos pela Constituição. Mas também possuem alguns direitos especiais pelo fato de terem uma história anterior ao Brasil, que 
são os direitos originários (sobre o território tradicional, por exemplo), e ainda os que são fruto da reparação do Estado brasileiro aos indígenas devido à violência, exclusão e perda da autonomia imposta à sua organização social, em decorrência do modo como se deu a formação do país (cf. Albuquerque e Nakashima, 2008).

São quatro os principais documentos que formam a legislação específica sobre o indígena no Brasil:

a) Lei 6.001 de 1973 (o Estatuto do Índio, posteriormente "dos Povos Indígenas");

b) Constituição Federal de 1988 (artigos 231 e 232);

c) Convenção no 169 de 1991 da Organização Internacional do Trabalho (OIT), da ONU;

d) Declaração sobre o Direito dos Povos Indígenas (DDPI) de 2007, da ONU.

A Constituição Federal de 1988 ampliou o Estatuto dos Povos Indígenas e incorporou à lei brasileira avanços significativos em relação aos direitos dos indígenas. No artigo 231 desta mesma Constituição são reconhecidos, aos indígenas, sua organização social, costumes, línguas, crenças e tradições, e os direitos originários sobre as terras que tradicionalmente ocupam, competindo à União demarcá-las, proteger e fazer respeitar todos os seus bens. No artigo 232, os indígenas, suas comunidades e organizações são também partes legítimas para a defesa de seus direitos e interesses, com o Ministério Público intervindo nos atos do processo.

A Convenção $n^{\circ} 169$ sobre Povos Indígenas e Tribais em Países Independentes que foi adotada no ano de 1989 e entrou em vigor internacionalmente em 1991 - é um documento da Organização Internacional do Trabalho (OIT). A OIT é uma agência constituída por 182 países-membros, que se converteu em 1946 (após a II Guerra Mundial) no primeiro organismo especializado da ONU com o objetivo de promover a justiça social e o reconhecimento internacional dos direitos humanos e trabalhistas. Esta Convenção passou a ter força de lei no Brasil em novembro de 2002, quando passou a reconhecer a auto-identificação como critério fundamental para a definição dos povos cujos direitos estão assegurados por ela.

Assim diz o seu artigo $1^{\circ}$ : a) a consciência de sua identidade indígena ou tribal deverá ser considerada como critério fundamental para determinar os grupos aos quais se aplicam as disposições da presente Convenção; b) o direito à posse e à propriedade 
de suas terras e territórios; c) o direito à consulta prévia aos povos indígenas e tribais toda vez que estejam previstas medidas legislativas ou administrativas que venham afetar as suas vidas.

Como um reforço jurídico a esta Convenção, soma-se a recente Declaração sobre o Direito dos Povos Indígenas (DDPI) da ONU, que inclui aspectos relevantes sobre os direitos culturais e étnicos coletivos; o direito à terra e aos recursos naturais; a manutenção das estruturas econômicas e os modos de vida tradicionais; o direito consuetudinário (conjunto de normas não-escritas, mas consagradas pelos usos e costumes tradicionais de um povo); e principalmente o direito coletivo à autodeterminação (autonomia em relação à sua organização social) (cf. Albuquerque e Nakashima, 2008).

\section{A consolidação dos direitos adquiridos}

Em meio à busca por seus direitos específicos e por uma reterritorialização étnica, a organização política que vem sendo engendrada pelos Pankararu tem gerado diversos e importantes frutos. Como exemplo, os Pankararu se tornaram o primeiro grupo indígena não-aldeado em São Paulo a ser reconhecido pela FUNAI (Sampaio, 2005), e em virtude deste reconhecimento, obtiveram direito à assistência do órgão indigenista por meio da Administração Executiva Regional (A.E.R) localizada em Bauru (SP). É sintomático observar que, embora exista um grande número de indígenas na cidade de São Paulo, o único posto de representação da FUNAI no Estado de São Paulo esteja localizado em uma cidade distante $320 \mathrm{~km}$ da capital do Estado de São Paulo. Percebe-se assim por meio da localidade da A.E.R. em São Paulo que a FUNAI prioriza o atendimento aos indígenas que estão presentes nas aldeias do interior do Estado.

Os Pankararu também foram reconhecidos como comunidade indígena pela FUNASA $/ \mathrm{SP}^{46}$. Por meio de reuniões da FUNASA e Prefeitura de São Paulo, foi possível a contratação de agentes de saúde pertencentes à comunidade Pankararu para

\footnotetext{
${ }^{46}$ Até o momento da pesquisa, estava em andamento a transição da atribuição do atendimento de saúde aos indígenas por parte da FUNASA para uma Secretaria especial vinculada ao Ministério da Saúde. Isso ocorreu devido a reivindicações em nível nacional de lideranças de várias etnias indígenas, descontentes com os serviços prestados pela FUNASA, além de diversas denúncias de irregularidades em relação aos contratos assinados por esta instituição.
} 
atuar na Unidade de Saúde do Real Parque ${ }^{47}$. Além disso, o vínculo com a FUNASA foi estabelecido também por meio da contratação de um motorista da comunidade Pankararu para o órgão de saúde (cf. Adorno et alli, 2004).

Como parte das atribuições da FUNASA/SP para os Pankararu em São Paulo, está o suprimento de medicamentos, próteses e óculos, assim como o agendamento para tratamentos de saúde no ambulatório de saúde indígena no hospital da UNIFESP. Também cabe ao órgão de saúde o auxílio-transporte para viagens à Terra Indígena em Pernambuco, assim como o prosseguimento do tratamento de saúde na aldeia e viceversa. A FUNASA/SP ainda se responsabiliza pelo translado do corpo de indígenas falecidos em São Paulo para sepultamento na aldeia natal (cf. Adorno et alli, 2004).

Segundo Adorno et alli (2004), um dado que adquire importância é o fato da Associação Pankararu ter iniciado um processo de cadastramento não apenas dos Pankararu na cidade de São Paulo, mas também de outras etnias indígenas presentes na cidade. Os critérios estabelecidos pela Associação para a identificação dos indígenas se dão por meio de averiguação por parte dos indígenas Pankararu mais velhos a respeito das “redes de conhecimento dos 'parentes' para identificá-los como índios dentro de sua ou de outra etnia" (Adorno et alli, 2004, p. 10). Também passaram a controlar junto aos órgãos de saúde (FUNASA, Ambulatório de Saúde Indígena, Unidade de Saúde) a identificação de indígenas, realizando consultas em seu cadastro e buscando informações junto aos mais velhos ou aos 'parentes' quanto ao pertencimento a uma determinada etnia. $\mathrm{O}$ autoreconhecimento se dá com base no cruzamento de informações com os mais velhos e também obtidas junto às comunidades de origem. Cabe lembrar que esse processo é realizado de certo modo devido à especificidade da migração dos povos indígenas a partir da Região Nordeste que vão formando comunidades em seus bairros de moradia em São Paulo. "A integração e o cruzamento de informações entre DSEI's ${ }^{48}$ e organizações indígenas podem, sem dúvida, mapear e sistematizar fluxos e reconhecimentos de outras comunidades em cidades brasileiras" (Adorno et alli, 2004, p. 13). Esse processo de auto-identificação merece atenção em razão dos critérios adotados pela comunidade indígena para a determinação da etnicidade de um determinado indivíduo ou não. De certo modo, a definição do que é ser indígena também está em processo de construção dentro das próprias comunidades.

\footnotetext{
${ }^{47}$ Embora tenha sido um direito consolidado após diversas reivindicações por parte dos Pankararu, tem havido, até o atual momento da pesquisa, movimentos por parte da Prefeitura de São Paulo para retirar este atendimento diferenciado na Unidade de Saúde do Real Parque.

${ }^{48}$ Distrito Sanitário Especial Indígena.
} 
Merece destaque também o Projeto Pindorama, que foi iniciado em 2001, que oferece bolsas de estudos para universitários indígenas, não apenas da etnia Pankararu, para estudarem na PUC-São Paulo, iniciativa que tem apoio da própria PUC, da FUNAI e da Pastoral Indigenista da Arquidiocese de São Paulo ${ }^{49}$. O projeto consiste em oferecer bolsas de estudo para estudantes indígenas que prestam o vestibular da PUC-São Paulo e, assim, ter acesso à universidade, uma medida completamente diferente da noção de cotas para estudantes socialmente desfavorecidos. Desse modo, preparados pelo Cursinho Pré-Vestibular da Poli, indígenas prestaram o vestibular no ano de $2001 \mathrm{e}$, em janeiro de 2002, 26 estudantes de três etnias - Pankararu (22 alunos), Guarani Mbyá (3) e Xavante (1) - foram aprovados e matriculados, surpreendendo a própria comunidade acadêmica da PUC-São Paulo. Segundo Prezia (2007), a capacidade de inserção dos indígenas na PUC foi vista com ressalvas até mesmo pela Universidade, que previa o acesso de um número entre cinco a dez indígenas na instituição, mas havia deixado aberta a inclusão de todos os indígenas que passassem pelo processo de seleção.

O grupo inicial de estudantes indígenas era composto, na sua maioria, por jovens do povo Pankararu, alguns deles nascidos em São Paulo. Em razão de diversos fatores, no ano seguinte (2002), a PUC restringiu o número de bolsas para 12, embora o número de indígenas de diversas etnias que buscavam o ingresso à Universidade aumentasse cada vez mais. Desse modo, inseriram-se na PUC alunos de diversas etnias como Atikum, Guarani Nhandeva, Kaingang, Krenak, Pankararé, Pataxó, Potiguara e Têrena, todos moradores da capital e da grande São Paulo. Passados seis anos do projeto, 75 indígenas freqüentaram cursos dos mais variados como: letras (português, inglês, espanhol), pedagogia, geografia, serviço social, fonoaudiologia, enfermagem, turismo, direito, administração, ciências contábeis, tecnologia em mídias digitais, multimeios, ciência da computação, matemática, engenharia elétrica e física médica. $\mathrm{O}$ projeto tem, por objetivo, não se restringir à capacitação profissional, mas também cooperar para a formação cidadã dos alunos, além de contribuir para o seu reconhecimento como membro de um grupo étnico. Para isso, realiza-se uma reunião mensal da qual todos devem participar, e, uma vez ao ano, é realizado um encontro de dois dias, para convivência e estudo (cf. Prezia, 2007).

\footnotetext{
${ }^{49}$ Segundo Prezia (2007), o projeto foi um esforço conjunto de diversos indivíduos e organizações, como Ana Maria Battaglin e Lúcia Helena Rangel (professores da PUC-SP); Hiparindi Toptiro (etnia Xavante); Associação S.O.S. Comunidade Indígena Pankararu e Pastoral Indigenista da Arquidiocese de São Paulo.
} 


\section{Os critérios de identidade étnica}

Tendo em vista os direitos que foram sendo consolidados pelos indígenas em São Paulo, percebe-se também, a despeito dos processos discriminatórios e de exclusão aos quais muitos deles são submetidos, uma tendência de valorização da etnicidade por parte de muitos que anteriormente negavam a sua condição de indígenas. No entanto, verifica-se também a tendência de alguns indivíduos que, por não possuírem exatamente uma ancestralidade indígena ou qualquer indício de que tenham uma possível identidade indígena, afirmem ser indígenas com o intuito de usufruir dos direitos garantidos pela legislação. Esse processo tem gerado intensas discussões, tanto entre as comunidades indígenas quanto nos órgãos que tratam da questão indígena, a respeito dos critérios para se determinar a identidade indígena dos indivíduos. Segundo Grupioni (2001), a necessidade de se definir claramente quem é indígena está vinculada à necessidade de se reconhecer quem deveria ser beneficiário dos direitos adquiridos. Para Vaz Filho (2006), essa definição depende, em muito, da própria subjetividade dos indígenas, mas também não se pode esquecer que a questão de quem é indígena seja objeto de disputa daqueles que pretendem negar-lhes a identidade, como empresas e fazendeiros que desejam ocupar as terras reivindicadas pelos indígenas e mesmo órgãos do governo, ou ainda, estabelecendo limitações ou critérios impostos por lei como fazem os Estados Nacionais. Daí a importância da discussão a respeito dos critérios que poderiam fundamentar a identidade indígena.

Segundo Cunha (1987), o critério mais antigo adotado foi o racial, no qual a definição de um grupo étnico seria determinada pelas ciências biológicas, que buscaria estabelecer as diferenças com base em características físicas. De acordo com essa visão, a espécie humana estaria dividida em grupos que partilhariam traços hereditários comuns e que seria possível de serem identificados de modo somático. O grupo indígena seria então formado por descendentes "puros" de uma população précolombiana. Embora seja uma concepção ainda muito presente no senso comum popular, esse critério já foi desmentido pela própria ciência, pois os indígenas não formam uma única raça, uma vez que são constituídos por populações que apresentam profundas diferenças entre si. Outro problema apresentado por esse critério é que dificilmente uma população se reproduz sem que ocorram miscigenações, de modo que poucos grupos caberiam neste tipo de definição (cf. Grupioni, 2001). 
Um segundo critério que veio a substituir o racial foi o da cultura. Desse modo, um grupo indígena seria aquele que partilharia valores, formas e expressões culturais de seus antepassados pré-colombianos, como a língua, a religião, técnicas e práticas cotidianas (cf. Grupioni, 2001). Segundo Cunha (1987), embora seja um critério que cumpra relativamente seu papel, para que ele seja utilizado de forma adequada, devem ser negados dois pressupostos:

a) o de tomar a existência dessa cultura como uma característica primária, quando se trata, pelo contrário, de conseqüência da organização de um grupo étnico; e b) o de supor em particular que essa cultura partilhada deva ser obrigatoriamente a cultura dos ancestrais (Cunha, 1987, p. 115).

Isso implica dizer que não devemos esquecer o aspecto dinâmico das culturas, que estão em constante transformação. Cabe lembrar que os grupos indígenas no Brasil passaram por diversos processos de imposição social e cultural, como a proibição da língua, de rituais e de mudança de ambiente, gerando mudanças inevitáveis. Desse modo, torna-se questionável definir os grupos indígenas com base na continuidade das práticas culturais, pois elas são, em sua essência, dinâmicas.

Ao se verificar a inadequação dos dois critérios anteriores, chegou-se a outro critério, vigente atualmente, que define os grupos étnicos como "formas de organização social em populações cujos membros se identificam e são identificados como tais pelos outros, constituindo uma categoria distinta de outras categorias da mesma ordem" (Cunha, 1987, p. 116). Estudos antropológicos têm concluído que os grupos étnicos podem apenas ser caracterizados pela própria distinção que percebem entre si próprios e os outros grupos com os quais interagem. Existem enquanto se consideram distintos, não importando se a distinção se realiza por meio de traços culturais ou não. Em relação a um critério individual de pertencimento aos grupos, isso depende somente de uma auto-identificação e do reconhecimento pelo grupo ao qual o indivíduo é pertencente. A identidade étnica de um grupo indígena é definida a partir de sua autoidentificação e da identificação da sociedade envolvente (cf. Cunha, 1987). 


\section{O bairro Real Parque e a EMEF José de Alcântara Machado Filho}

Seria interessante realizar uma caracterização do bairro Real Parque, pois é nele que está localizada a maior parte da população Pankararu em São Paulo e suas duas associações, tornando-se então uma espécie de referência tanto para os Pankararu em São Paulo e de Pernambuco, como para outras etnias indígenas em São Paulo. É também no Real Parque que está localizada a EMEF Alcântara, na qual realizamos nossa pesquisa e que atende a muitos alunos da etnia Pankararu.

De acordo com Iglecias (2002), o bairro Real Parque foi oficialmente constituído em meados da década de 1960, encontrando-se assentado em terreno público sobre um morro do subdistrito do mesmo nome, entre os bairros do Morumbi e do Brooklin, encontrando-se separados pelo Rio Pinheiros. Tem como vizinhança um terreno desocupado de propriedade da Eletropaulo e diversos condomínios residenciais de alto padrão, situados no subdistrito vizinho de Paineiras do Morumbi.

O bairro, com seus barracos, casas de alvenaria e conjuntos habitacionais do Cingapura, está localizado à margem do Rio Pinheiros e apresenta um cenário bastante contrastante tanto em relação aos prédios de alto padrão do bairro do Morumbi, que circundam a região, como com o distrito de negócios situado na Avenida Luís Carlos Berrini, no bairro do Brooklin, do outro lado da margem do Rio Pinheiros, que concentra em sua extensão e imediações as sedes das empresas ligadas ao setor terciário avançado. A avenida está inserida na região conhecida como Vetor Sudoeste, que se caracteriza como uma área de expansão econômica que vem acompanhando a trajetória de desenvolvimento da cidade ao longo do século XX. A construção dessa avenida, que data da década de 1980, vem sendo acompanhada por grande polêmica, pois, segundo análises de especialistas em planejamento urbano, ela se tornou palco de um grave desastre social, visto que a proliferação das grandes empresas na região teria expulsado a população de baixa renda que ali vivia para as áreas mais periféricas da cidade (cf. Fix, 2001). De acordo com Iglecias (2002), tal quadro apresenta uma disposição espacial muito comum nas grandes metrópoles mundiais, onde se verifica a proximidade física entre realidades sócio-econômicas extremamente contrastantes, evidenciando-se, de um lado, a ostentação de prédios de grandes conglomerados financeiros e condomínios residenciais de alto padrão e, de outro, a desolação de bairros pobres e favelas descuidadas pelo poder público. Cabe lembrar que o contexto das favelas se insere na lógica da expansão imobiliária da cidade e de barateamento da mão- 
de-obra, passando posteriormente a serem vistas como "anomalias do desenvolvimento urbano e um mal a ser extirpado" (Iglecias, 2002, p. 54). Essa formulação ideológica oculta as pressões do capital imobiliário que vêem as favelas como obstáculos para a valorização financeira dos terrenos pretendidos, exigindo que sejam removidas, o que de fato ocorreu em situações nas quais o poder público se aliou ao interesse privado, expulsando, na maior parte das vezes, com violência, seus habitantes.

Segundo um censo elaborado em 2004 pelo Projeto Casulo, o Real Parque é constituído por aproximadamente 5.300 habitantes, que residem em 884 barracos, 489 unidades habitacionais do conjunto Cingapura e também em inúmeros alojamentos. A maior parte da população é formada por migrantes e descendentes nordestinos, que se instalaram na comunidade em grande número na década de 1950, em virtude das dificuldades de subsistência encontradas em suas terras de origem, sendo assim composta: $25,2 \%$ de pernambucanos, $17,8 \%$ de baianos, $12,7 \%$ de mineiros, $8,1 \%$ de paraibanos, 6,5\% de cearenses, 3,4\% de alagoanos e 17,8\% de paulistas, Conforme depoimentos dos moradores mais antigos, o Real Parque nasceu com a vinda de famílias da etnia indígena Pankararu oriundas do Nordeste, para trabalhar na construção do estádio do Morumbi.

No entanto, é na década de 1970 que as primeiras residências de médio e alto padrão passam a ser construídas na região. Com a intensificação do processo de urbanização e verticalização, reflexo do tipo de desenvolvimento excludente da metrópole, o bairro passou por gradativo adensamento demográfico, o que contribuiu para que os loteamentos irregulares passassem a ser ocupados por populações de baixa renda que ali se estabeleciam em busca de melhores condições de trabalho.

A comunidade ocupa hoje uma área constituída basicamente por terrenos de altos declives e vales profundos, caracterizados, em grande parte, como áreas de risco, com possibilidade de deslizamentos de terra. Essa comunidade apresenta características bastante peculiares por dois fatores: o primeiro é por ocupar terrenos pertencentes ao Departamento Estadual de Estradas de Rodagem (DER), além de outros terrenos particulares; o segundo é que ela está localizada junto a casas e edifícios de altíssimo padrão, pertencentes ao bairro do Morumbi. É em razão disso que o bairro possui uma das maiores rendas médias per capita da cidade de São Paulo. Segundo levantamento feito em 2004, 92\% dos moradores eram proprietários do imóvel onde moravam e 41\% haviam-no adquiridos à vista. É justamente a proximidade com um bairro de alta classe que faz com que os terrenos da comunidade, especialmente do alojamento, se tornem 
alvo de especulação imobiliária, fazendo com que a pressão do governo pela remoção das favelas da região se eleve. Outro agravante é a miopia administrativa dos órgãos públicos, que, ao considerar a elevada renda média per capita da região (muito mais em razão da renda dos moradores de classe média e alta), não vêem razão para investimentos nas áreas básicas de saúde, educação e transporte. Verifica-se, então, a precariedade dos serviços públicos existentes no local: não existe hospital público nas proximidades e o único posto de saúde do bairro é considerado inadequado, pequeno e insuficiente; não existe escola de ensino médio na região; em relação ao transporte público, não há linhas regulares de ônibus, ocasionando a dificuldade de acesso à grande parte da região do Butantã. Tal condição também dificulta o acesso às escolas e hospitais públicos do entorno. Em termos de educação, os moradores são atendidos somente por duas escolas públicas - a EMEI Pero Neto e a EMEF Alcântara, restringindo, assim, as opções de formação de alunos das comunidades pobres do Real Parque.

Entre os problemas sociais e estruturais que afligem a população da comunidade, destaca-se o desemprego, que atinge $63 \%$ da população adulta. A infra-estrutura é precária: a falta de canalização e a existência de vielas extremamente estreitas facilitam a incidência de incêndios e a inundação de barracos em virtude de enchentes.

O Real Parque foi inicialmente poupado da remoção de favelas ocorrido no Vetor Sudoeste. No entanto, a construção do Complexo Viário Real Parque, inaugurado em maio de 2008, do qual faz parte a Ponte Estaiada ${ }^{50}$, juntamente com a inauguração do Shopping Cidade Jardim ${ }^{51}$, situados à margem do Rio Pinheiros, do mesmo lado do Real Parque, vem trazendo novas pressões sobre os habitantes do Real Parque.

\footnotetext{
${ }^{50}$ A ponte foi construída para ser um marco da arquitetura e da engenharia da cidade de São Paulo. A sua visibilidade tem sido muito explorada em diversos comerciais de TV e especialmente nos noticiários da TV Globo, que possui sua sede em São Paulo nas proximidades do Real Parque.

${ }^{51}$ A inauguração do Shopping, segundo informes publicitários, pretende marcar "o surgimento na cidade de uma nova geração de empreendimentos comerciais" e de ser o "o primeiro shopping center aberto na cidade, com luz natural, e lojas de frente para jardins". Informações obtidas em press-releases do Shopping Cidade Jardim encontrados no site: http://www.shoppingcidadejardimjhsf.com.br/shopping.aspx.
} 


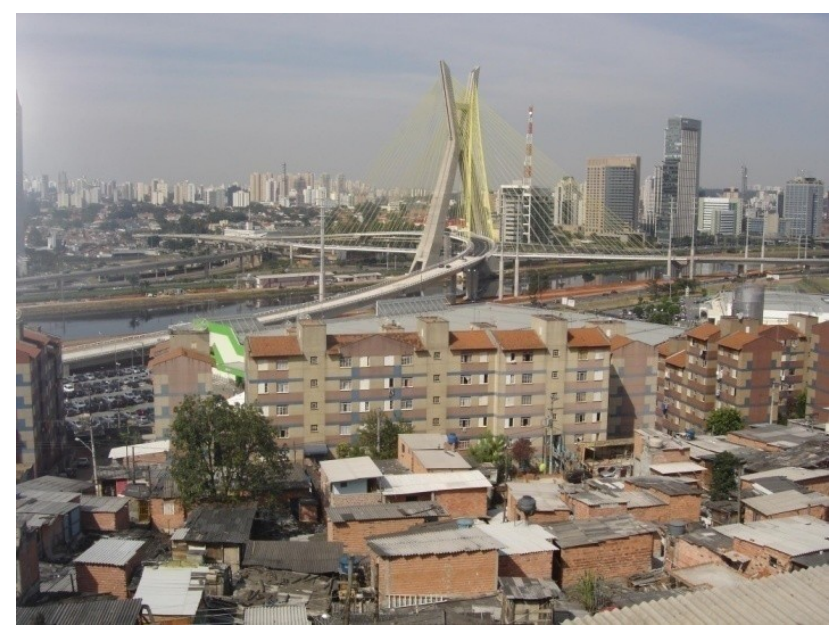

Real Parque. Crédito: Marcos Albuquerque

\section{A reintegração de posse}

Um evento ocorrido no dia 11 de dezembro de 2007 demonstrou claramente a pressão imobiliária que vem sendo exercida sobre este bairro. Nesse dia, o $16^{\circ}$ Batalhão da Polícia Militar na Marginal do Rio Pinheiros bloqueou duas das três pistas locais da Marginal Pinheiros, no sentido Interlagos, com o intuito de cumprir um mandado de reintegração de posse expedido pelo juiz da $3^{\mathrm{a}}$ Vara Cível de Santo Amaro referente a um terreno de 17 mil metros quadrados pertencente à EMAE - Empresa Metropolitana de Água e Energia -, de capital público-privado e ligada ao Governo do Estado (cf. Furui e Capuchinho, 2007).

Segundo os próprios moradores, esse terreno, pertencente à favela do Real Parque, começou a ser ocupado há cerca de três anos. Regularizado por uma escritura datada de 1937, estava sem aparente uso ou destinação social há 70 anos, de acordo com a Defensoria Pública do Estado de São Paulo. Além disso, documentos registrados há mais de cinco anos, como contas de água dos moradores na parte superior do terreno da EMAE, possibilitariam o direito ao pedido de usucapião do espaço.

Sem aviso prévio, órgãos como a Sub-Prefeitura do Butantã, a Guarda Civil Metropolitana, o Conselho Tutelar, o Corpo de Bombeiros, a CET e a Polícia Militar com Tropa de Choque deram início à ação. Segundo Araújo (2007), os moradores foram acordados às 6 horas pelo oficial de Justiça e, segundo o subprefeito do Butantã, Maurício Pinterich, tiveram uma hora e meia para deixarem as casas. Posteriormente, ao verem suas casas sendo derrubadas, os moradores iniciaram o protesto realizando o bloqueio do trânsito da pista expressa da marginal, ação que durou cerca de cinco 
minutos, tempo suficiente para a Força Tática do $16^{\circ}$ Batalhão entrar em ação. Houve resistência dos moradores, o que ocasionou confronto também dentro do bairro. A ação durou mais de dez horas e foi extremamente violenta, resultando em um grande número de moradores feridos. Na ação policial, foram utilizadas balas de borracha, cassetetes, bombas de gás lacrimogêneo e spray de pimenta, inclusive contra mulheres e crianças que estavam presentes no local (cf. Furui e Capuchinho, 2007).

Ao final da tarde, a parte do terreno de ocupação mais recente havia sido demolida. Em torno de 70 famílias ficaram desabrigadas, sendo que 20 foram direcionadas a diversos hotéis espalhados pela cidade e duas delas, abaladas pelos eventos ocorridos, aceitaram as passagens oferecidas pela Empresa para cidades no nordeste, ressaltando-se que esse procedimento pode ser qualificado como uma atitude claramente discriminatória para com populações desfavorecidas e que desrespeita o direito de ir e vir de qualquer cidadão. O restante das famílias contou com a solidariedade de outros moradores ou se instalou de forma provisória na sede da ONG Casulo e na EMEI Pero Neto, onde refeições coletivas foram organizadas. Outro dado é o fato de dezenas de crianças e adolescentes terem perdido o ano letivo por conta da mudança forçada de endereço. Nos dias seguintes, protestos foram organizados pelas associações dos moradores e ONG's como a Favela Atitude, que se posicionaram diante da Câmara dos Vereadores e em outros locais da cidade de São Paulo, reivindicando a suspensão da reintegração de posse. Esta mobilização contou, inclusive, com a participação de alguns dos indígenas Pankararu.

No dia 17 de janeiro de 2008, a Defensoria Pública do Estado de São Paulo entrou com o pedido de suspensão da reintegração de posse do terreno do EMAE, sendo esta também acusada de ter encaminhado processos iguais a dois juízes diferentes. A decisão pela indenização dos moradores que foram despejados por danos morais e materiais ficou a cargo da Justiça, mantendo o impasse da situação ${ }^{52}$.

\section{A reivindicação dos moradores da comunidade do bairro Real Parque}

O dramático evento ocorrido é apenas um indicativo da pressão exercida pelas empresas e poder público sobre os moradores do bairro Real Parque. No boletim informativo "Real Parque contra o despejo e pela moradia" (2007), elaborado logo após a ocupação por moradores do Real Parque e apoiadores, estão relacionadas às

\footnotetext{
${ }^{52}$ Conforme informações coletadas no vídeo "Na real do Real”, produzido pela Favela Atitude.
} 
reivindicações dos moradores e alguns dados relevantes a respeito da situação do bairro $^{53}$. Segundo o boletim, os moradores do bairro já têm reivindicado há muito tempo ações efetivas do Poder Público em busca da melhoria das condições de habitação do bairro Real Parque.

Como um dos fortes argumentos levantados pelos moradores no boletim, está a questão de que o bairro Real Parque existe desde a década de 1960, quando todo o entorno do bairro era constituído somente de chácaras, sendo, portanto, anterior às Avenidas Marginais, às mansões e condomínios da região, à Avenida Berrini e à Avenida Roberto Marinho, e claro, muito mais antiga do que a Ponte Estaiada construída de frente à favela, caracterizando-se, assim, como um forte indicador de direito dos moradores de permanência na área.

O boletim também informa que, com os instrumentos do Estatuto da Cidade e com o Plano Diretor Participativo aprovado em 2004, o bairro Real Parque teria se tornado uma ZEIS $1^{54}$, o que protegeria a área do Real Parque por lei e garantiria a construção de $80 \%$ de habitação para população de baixa renda. Sendo a área ZEIS 1, deveria existir um Plano de Urbanização Participativo com Conselho Gestor paritário para que o Projeto de Urbanização seguisse as diretrizes do Plano. Conscientes disso, os moradores do bairro já haviam se encaminhado à subprefeitura do Butantã e à Secretaria da Habitação para questionar o projeto e a implementação do Conselho Gestor por parte da Prefeitura.

De acordo com o boletim ainda, tanto o Real Parque como as favelas vizinhas Jardim Panorama e Coliseu foram incluídas nas contrapartidas ${ }^{55}$ da Operação Urbana Faria Lima, o que implicaria na promessa de que os recursos arrecadados com esta

\footnotetext{
${ }^{53}$ As reivindicações foram: retirada imediata do mandado de reintegração de posse; plano de urbanização com instituição do conselho gestor e projeto participativo que atenda às necessidades de moradia dos moradores da favela Real Parque (nenhuma família a menos); aplicação dos recursos da operação urbana Faria Lima destinados às favelas da região; atendimento (moradia) definitivo e acompanhamento social às famílias removidas pela ação de reintegração de posse; indenização às famílias feridas na ação policial; investigação sobre os abusos da ação da polícia na ação de reintegração; fim imediato das remoções.

${ }^{54}$ Segundo o Plano Diretor Estratégico do Município de São Paulo, Zeis - Zonas Especiais de Interesse Social - são porções do território destinadas, prioritariamente, à recuperação urbanística, à regularização fundiária e produção de Habitações de Interesse Social - HIS ou do Mercado Popular - HMP, incluindo a recuperação de imóveis degradados, a provisão de equipamentos sociais e culturais, espaços públicos, serviço e comércio de caráter local. Nesse caso, ZEIS 1 seriam áreas ocupadas por população de baixa renda, abrangendo favelas, loteamentos precários e empreendimentos habitacionais de interesse social ou do mercado popular, em que haja interesse público expresso por meio desta lei, ou dos planos regionais ou de lei especifica, em promover a recuperação urbanística, a regularização fundiária, a produção e manutenção de Habitações de Interesse Social - HIS, incluindo equipamentos sociais e culturais, espaços públicos, serviço e comércio de caráter local. Fonte: http://www6.prefeitura.sp.gov.br/secretarias/planejamento/plano diretor/0004.

${ }^{55}$ Estava previsto, com o desenvolvimento desta Operação, contrapartidas no sentido de melhorias para as populações residentes nas favelas.
} 
Operação fossem ser revertidos para a construção de moradias nessas favelas. Os moradores, há muito tempo, têm cobrado essas ações e promessas, mas até a presente data, nenhuma iniciativa foi tomada nesse sentido por parte do governo e dos órgãos responsáveis.

Foi no ano de 2007, que os moradores do bairro tiveram ciência de um projeto de urbanização para o Real Parque elaborado pela Secretaria da Habitação. De acordo com esse Projeto, estaria prevista a alocação de 750 famílias em unidades verticalizadas de 12 andares. No entanto, excetuando os moradores do Cingapura, habitariam no bairro aproximadamente 1200 famílias, sem contar o detalhe de que as famílias teriam dificuldades em pagar condomínio de prédio de 12 andares, já que a renda familiar média dos moradores do Real Parque é de um a três salários-mínimos. Ainda que este projeto seja implementado, o temor dos moradores é de que, uma vez removidas em decorrência do projeto, as famílias não mais retornem à área do Real Parque, tomando como exemplo a construção do Cingapura, no qual até a presente data existem famílias que foram desalojadas de suas casas e ainda continuam morando nos alojamentos "provisórios". Detalhes do plano de urbanização do bairro têm sido apresentados aos moradores e tem sido motivo de boatos e discussões entre os moradores da comunidade. Interessante destacar que no mês de setembro de 2008, alguns membros de uma associação de moradores dos condomínios do bairro promoveram um encontro com a comunidade Pankararu no Centro de Apoio à Criança "O Visconde", com o intuito de apresentar algumas propostas do projeto de reurbanização do bairro, sendo uma delas a construção de um espaço específico para a comunidade Pankararu no Real Parque. No encontro, houve uma apresentação do Toré para os presentes e depois um breve diálogo de apresentação das propostas para a liderança da comunidade Pankararu em caráter formal, uma iniciativa que deixou claro a quem interessa o projeto de reurbanização, uma vez que a iniciativa foi dos moradores de maior renda aquisitiva do bairro, com claro interesse em ganhar uma parte dos moradores que tem maior visibilidade social, ou seja, os indígenas.

\section{A EMEF Alcântara}

Feita a caracterização do contexto social da favela do Real Parque, podemos centrar nos aspectos educacionais. A comunidade é atendida por certo número de creches conveniadas, que são consideradas insuficientes para atender à demanda local. Foi apenas na gestão do governador Mario Covas, no ano de 1986, que foram criadas 
tanto a EMEI Pero Neto como a EMEF Alcântara para atender crianças dos níveis Infantil e Fundamental I e II. Todos esses fatos demonstram a extensão da precariedade do atendimento escolar à comunidade deste bairro, que se agrava com a inexistência de uma escola de Ensino Médio, reivindicação constante dos moradores.

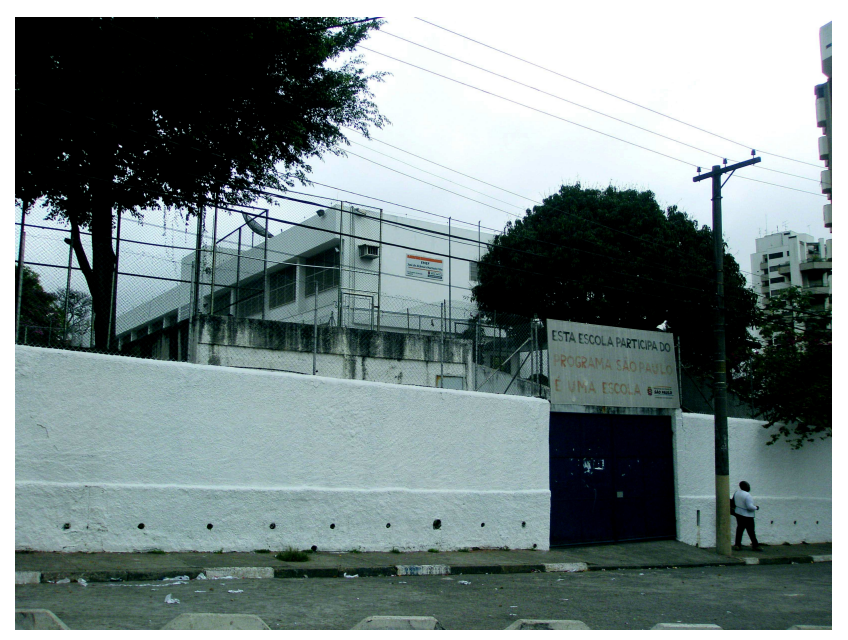

A EMEF Alcântara, única escola municipal de ensino fundamental do Morumbi, onde realizamos nossas pesquisas, apresentava, segundo o projeto Político Pedagógico de 2004, no ciclo I do nível fundamental, duas séries do $1^{\circ}$ ano, quatro séries do $2^{\circ}$ ano, duas séries do $3^{\circ}$ ano e quatro séries do $4^{\circ}$ ano e no ciclo II do nível fundamental, quatro $5^{\mathrm{a}} \mathrm{s}$ séries, cinco $6^{\mathrm{a}} \mathrm{s}$ séries, seis $7^{\mathrm{a}}$ séries e seis $8^{\mathrm{a}} \mathrm{s}$ séries, além de quatro classes de suplência, funcionando nos três períodos. Mas, conforme observado em 2008, pudemos constatar que houve uma redução drástica das classes de suplência e mesmo de classes regulares à noite, seja por desistência dos alunos, seja porque foram "desestimulados" a se matricularem. $\mathrm{O}$ argumento da diminuição das turmas à noite por parte da diretoria era de que não havia mais uma demanda nesse sentido, pois com a progressão continuada e a universalização do ensino tinha diminuído o número de alunos excluídos da escola. Ocorre que, conforme levantamento feito na região, mais de $40 \%$ da população adulta não havia sequer concluído o primeiro ciclo do nível Fundamental.

\section{Uma educação à deriva}

Pudemos constatar in loco, na pesquisa que realizamos entre 2006 e 2008, os diversos e crônicos problemas apresentados pela escola. Segundo Amaral (2007), em 
abril de 2007, o Projeto Casulo ${ }^{56}$ promoveu um Encontro entre moradores, instituições de ensino e demais instituições do Real Parque e Jardim Panorama para debater questões referentes à educação no bairro. Esse encontro contou com a presença de jovens que freqüentam o Projeto Casulo, seus pais, diretoras da EMEI Pero Neto e EMEF Alcântara, a representante da Coordenadoria de Educação do Butantã, além de representantes das entidades: Associação Cultural e Esportiva SOS Juventude, Centro de Apoio à Criança "O Visconde", Centro Comunitário "Ludovico Pavoni”, Núcleo Sócio-educativo, Associação SOS Pankararu e União de Moradores do Jardim Panorama. Transcrevemos a seguir a tônica das discussões realizadas neste dia, que demonstram um quadro bastante realista dos problemas educacionais vividos na comunidade do Real Parque, praticamente colocando a EMEF Alcântara no centro das discussões e escancarando os diversos problemas relativos a essa escola, numa clara demonstração de que eles não passavam despercebidos pelos membros da comunidade.

\section{A falta “de" professores ou "dos" professores - ou ambos?}

Depois da apresentação de algumas das associações e das escolas da comunidade, houve um momento aberto para discussão e uma liderança da comunidade indígena Pankararu fez a seguinte questão para a diretora da EMEF Alcântara:

“- Por que os professores faltam tanto? Por que ninguém quer dar aula nessa escola?". A pergunta tocou em um ponto vital da escola, que era o problema crônico de falta de professores na escola, o que provocava situações em que, nos diversos períodos da escola, salas inteiras ficavam sem aula, quando muito fazendo alguma atividade proporcionada pelo inspetor de alunos. A situação se tornava ainda pior quando faltavam os professores de português e de matemática, matérias que, além de serem vitais para o aprendizado do aluno, possuíam maior carga horária. Cabe observar que as lideranças Pankararu optaram por matricular seus filhos e netos em outras escolas ao redor do Real Parque e não na EMEF Alcântara, o que é sintomático do que esta escola representa para a comunidade indígena.

A diretora, na reunião, respondeu à indagação dizendo que havia falta de professores e "falta" dos professores. Relatou que, na escola, faltavam apenas alguns

\footnotetext{
${ }^{56}$ O Projeto Casulo é uma ONG presente na comunidade do Real Parque, que proporciona diversos cursos e oficinas aos moradores do bairro. A intenção desse relato, embora circunstancial, é o de apresentar um quadro das dificuldades presentes na EMEF Alcântara e também da relação desta escola com a comunidade.
} 
professores para a composição do quadro e que muitos estavam em licença, sendo que não era possível substituir esses últimos. Procurou tranqüilizar os pais, garantindo que as crianças sem aulas eram "realocadas" em outras salas, não perdendo, portanto, as aulas. Na realidade, traçou um quadro muito diferente do que observávamos no cotidiano escolar, em que mais de 240 alunos por período ficam praticamente à deriva, sem professores, portanto sem nenhuma referência adulta.

Quando foi perguntado à representante da coordenadoria de ensino sobre os motivos de não se contratar professores em número suficiente, ela atribuiu o problema, antes de tudo, aos próprios professores da escola, reiterando que o maior problema da EMEF não era a falta de professores, mas sim a falta dos professores. Em todo caso, tentou explicar como era feita a reposição de professores, dizendo que toda quarta-feira havia atribuição de aulas, mas que cabia à escola avisar a coordenadoria a respeito das licenças para que as substituições fossem realizadas. Comentou que seria preciso olhar com atenção especial para o Alcântara, já que muitos questionamentos foram feitos especificamente a respeito dessa escola.

De acordo com Amaral (2007), em diversos momentos da pesquisa, os professores relataram que, no sistema anterior de contratação, eles próprios podiam redistribuir as aulas entre si ou indicar pessoas do bairro para contratação como professor. No sistema atual, a designação de professores e a atribuição das aulas passaram a ser centralizadas pelo NAE, com o intuito de evitar qualquer tipo de favorecimento local. Ocorre que muitos professores adjuntos perdem suas aulas em função da designação de outros que são contratados, mas que nem chegam a ocupar seus postos, em virtude, muitas vezes, da dificuldade de acesso ao bairro Real Parque, deixando a escola sem professor e, claro, sem aulas. O sistema burocrático implementado impede uma resposta imediata para os problemas de reposição de professor, questão que se vê agravada pela falta de empenho da direção da escola em formar turmas à noite. Um problema que tem gerado um efeito em cascata: os professores titulares da noite, ao perderem suas aulas, assumem as aulas dos professores adjuntos da manhã (fato que ocorreu na metade do ano letivo); estes, por ficarem com poucas aulas, faltam à escola, dando prioridade para outras escolas onde teriam maior carga horária. Os professores faltantes não são substituídos porque a Secretaria Municipal decidiu não contratar professores eventuais. Em 2008, vários professores foram contratados em caráter temporário para atender a essa demanda, mas seus contratos terminariam um mês antes das eleições municipais (outubro/2008), ou seja, 
antes do fim do ano letivo, não podendo ser renovados por lei. Assim, esses professores em regime temporário foram dispensados, deixando os alunos e a escola à míngua novamente, demonstrando, assim, a total falta de planejamento do Município em relação à questão.

\section{A quebra de autoridade}

Em meio a toda esta situação caótica, os alunos, por sua vez, ao sentirem tal descaso por parte da escola em relação a eles próprios, não vêem razão de respeitar os professores e a própria escola. Colabora para isso também uma nítida animosidade entre diversos professores e a diretora da escola, considerada autoritária e ausente, motivando muitos deles a pedir remoção para outras escolas. A tensão entre professores e direção é percebida pelos alunos. A falta de liderança e de uma direção não arbitrária, mas justa, gera, portanto, uma série de problemas em cascata e profunda quebra da autoridade em relação ao corpo docente, contaminando os próprios alunos e aprofundando a situação de abandono da escola. Como resultado, muitas decisões são tomadas, mas não são devidamente comunicadas a todos, o que gera uma confusão maior ainda, com ordens e contra-ordens atravessando o cotidiano da escola. Os professores se fragilizam e ficam à mercê dos mandos e desmandos da direção da escola e da secretaria (cf. Amaral, 2007).

Os alunos, cientes do abandono ao qual estão expostos, reagem a esse quadro caótico de diversas formas, muitas vezes, agindo com desrespeito com professores, agentes escolares e, principalmente, com os próprios colegas. Os professores, como forma de buscar estabelecer sua autoridade, claramente perdida, respondem à manifestação dos alunos de diversas formas, recorrendo ao "grito" para chamar a atenção dos alunos, algo que tem se tornado uma prática recorrente no cotidiano da escola. Tal fato não passou despercebido pela comunidade, pois, ao final da reunião, um dos presentes perguntou por que se gritava tanto com os alunos e por que alguns alunos eram agredidos fisicamente por funcionários, outra denúncia grave. A resposta a todos esses questionamentos foi dada por meio de promessas de maior atenção às referidas requisições, mas acabando por não resultar em nenhuma medida prática.

\section{A questão do "letramento"}

Outro tema abordado foi a dificuldade observada nos alunos em relação à leitura e à escrita. Questionou-se por que os alunos não estavam conseguindo aprender a ler e 
escrever na $1^{\mathrm{a}}$ série e nas séries posteriores. A questão colocada pela comunidade foi de como reverter a situação precária de aprendizado dos alunos da EMEF e quais respostas as autoridades governamentais presentes iriam oferecer a ela. A representante da coordenadoria de ensino ponderou sobre as dificuldades da "progressão continuada", comentando que talvez houvesse a falta de uma recuperação paralela para as crianças com defasagem na aprendizagem. Por fim, ponderou que os programas especiais, TOF (Toda Força ao $1^{\mathrm{o}}$ Ano), na $1^{\mathrm{a}}$ série, ou o PIC (Projeto Intensivo do Ciclo I), na $4^{\mathrm{a}}$ série, são propostas que foram criadas para atender a essa demanda, ou seja, alfabetizar os alunos que estivessem com dificuldades de aprendizado. A fala da representante da coordenadoria de ensino foi contestada por uma representante da comunidade, que relatou que as crianças de 11 a 12 anos, atendidas pela instituição em que trabalhava (Núcleo Sócio-Educativo) e que eram provenientes da EMEF, não sabiam ler nem escrever. Enfatizou que a situação exigia providências urgentes e ponderou que o TOF e o PIC atendiam poucos alunos e os que não participavam desses programas passavam então a ficar "excluídos da alfabetização". Contestou também a proposta de reforço escolar, uma vez que não havia sequer um número suficiente de professores para as aulas regulares. Como uma tentativa de resposta, a representante da coordenadoria de ensino sugeriu apenas soluções paliativas e, por fim, remeteu a busca de alternativas para os problemas apontados para a própria comunidade, dizendo ser necessário contar com voluntários para a realização de todo esse trabalho, o que significava o reconhecimento implícito da impossibilidade de contratação de professores ou mesmo da falta de estrutura e competência administrativa do Município (cf. Amaral, 2007).

\section{Participação da comunidade na escola}

Outros questionamentos foram levantados diretamente à diretora da EMEF, relacionados a uma real participação da comunidade na escola. Uma jovem da comunidade perguntou, por exemplo, por que não era possível utilizar as quadras no final de semana. A utilização passou a acontecer somente depois do apoio recebido por parte dos professores para a utilização das quadras e pressão exercida junto à diretora pela Associação SOS Juventude. Uma das atividades desenvolvidas por essa Associação foi proporcionar futebol aos sábados na quadra esportiva da escola a jovens da comunidade, o que foi permitido a duras penas. Em intervenções em sala de aula, os 
alunos tinham deixado claro que aquilo que mais apreciavam da escola, a quadra, estava lhes sendo vedada por parte da direção, sem nenhuma justificativa.

Segundo o presidente da Associação SOS Juventude, que é também inspetor da EMEF, falta "vontade" por parte da diretoria de "abrir as portas" para que a comunidade participe de programas e eventos na escola. Em seu relato aos pesquisadores, diz que nos últimos cinco anos, tem tido uma série de dificuldades para desenvolver trabalhos com a comunidade, exatamente por causa desses problemas relacionados à direção da escola. Deixa claro que só conseguiu utilizar o espaço da escola pelo apoio obtido dos professores, uma vez que a Diretora fez tudo para impedir que isso ocorresse. É preciso lembrar que na região da escola não existe espaço público para recreação dos jovens, sobretudo para os de baixa renda, a não ser aqueles propiciados pelas ONGs que atuam junto às comunidades consideradas carentes. Torna-se um verdadeiro contra-senso que uma das poucas instituições públicas existentes no bairro como a EMEF não abra seu próprio espaço para uma comunidade que se encontra à margem de seu próprio bairro, uma iniciativa presente já em diversas escolas e que tem gerado bons frutos para o ambiente escolar (cf. Amaral, 2007).

\section{Uma escola de ensino médio}

Um questionamento levantado pelos participantes do encontro para a representante da coordenadoria de ensino foi justamente a falta de uma escola de ensino médio no bairro. A ausência de uma escola de ensino médio obriga os jovens da comunidade a se locomoverem para estudar em outros bairros, o que implica em custos de condução e, em razão disso, pode ser um desestímulo para a continuidade de seus estudos.

A representante da coordenadoria respondeu que existia uma proposta de parceria entre a Prefeitura e o Estado para que a EMEF pudesse ser utilizada como escola de Ensino Médio à noite, uma proposta plausível, mas que devido às questões de mudanças na condução da prefeitura, esse projeto foi arquivado. Ela reconheceu as dificuldades existentes na construção de uma escola de Ensino Médio. O representante da comunidade que havia levantado essa questão deixou claro que a proposta era de uma parceria entre o Estado e a Prefeitura e não de construir outra escola, o que levaria muito mais tempo para resolver. Mas ficou evidente a falta de empenho dos poderes públicos para atender a referida demanda. De qualquer modo, a representante da 
Coordenadoria de Educação registrou todas as falas do encontro para a elaboração de um relatório a ser entregue ao Coordenador de Educação do Butantã, em que abordaria, sobretudo, a questão da falta de professores, para que documentos escritos pudessem chegar às instâncias superiores.

O abandono, existente em diversos níveis da escola, fica bastante claro, abandono que começa não apenas com a ausência da direção, mas, sobretudo, com a falta de políticas públicas coerentes com a realidade daquela escola. A política de atribuição de classes e o caos por ela gerado, deixando tantos alunos sem aula, e a distribuição de material escolar e alimentar durante as aulas desvia a escola de seu objetivo principal.

Diante de todas essas revelações tão contundentes e escancaradas sobre o caos na escola e a violência em seu exterior, mas muito presente no cotidiano de uma comunidade de pessoas pobres, que vivem em barracos a um quarteirão dos prédios mais luxuosos do Morumbi, uma série de questionamentos surge: é possível oferecer um ensino de qualidade a tais alunos em uma escola que apresenta tamanhos problemas? É possível disponibilizar uma educação diferenciada que atenda às especificidades das histórias e culturas afro-brasileiras e indígenas nesse estabelecimento? Como inserir a história e a cultura indígena na escola quando nem mesmo alunos não-indígenas estão obtendo uma educação de qualidade? Há possibilidade de se oferecer uma maior atenção às peculiaridades dos alunos Pankararu na escola? 


\section{A temática indígena nas escolas}

Nesta parte da dissertação, iremos recuperar uma discussão teórica a respeito da temática indígena nas escolas, considerando que não há nenhuma legislação específica a respeito de uma educação indígena em estabelecimentos de ensino que não são indígenas. A educação escolar indígena passou a ser um tema muito discutido entre indígenas, antropólogos, educadores e instâncias do governo ${ }^{57}$. Muitos estudos têm sido realizados para que seja possível a criação de escolas e currículos que sejam sensíveis às peculiaridades das culturas, saberes, tradições e modos de vida das populações indígenas $^{58}$. O caminho ainda é longo e tortuoso. No entanto, estamos falando, na maioria das vezes, de escolas que estão inseridas em comunidades tradicionais ou aldeias.

As estatísticas do Censo de 2000 demonstram que mais da metade da população indígena no Brasil está vivendo nas zonas urbanas. Embora muitos contestem essas estatísticas, não deixa de ser verdade que escolas presentes nas cidades podem estar acolhendo alunos indígenas, mesmo que a própria comunidade escolar não esteja ciente disso. Com a vinda dos indígenas para as cidades e com a inserção deles nas escolas, visualizamos outro nível de complexidade que apontam para diversas e significativas questões: há possibilidade de uma educação diferenciada para os indígenas em uma

\footnotetext{
${ }^{57}$ Segundo Grupioni, "a legislação que trata da educação escolar indígena tem apresentado formulações que dão abertura para a construção de uma escola indígena que, inserida no sistema educacional nacional, mantenha atributos particulares como o uso da língua indígena, a sistematização de conhecimentos e saberes tradicionais, o uso de materiais adequados preparados pelos próprios professores índios, um calendário que se adapte ao ritmo de vida e das atividades cotidianas e rituais, a elaboração de currículos diferenciados, a participação efetiva da comunidade na definição dos objetivos e rumos da escola. A legislação também tem colocado os índios e suas comunidades como os principais protagonistas da escola indígena, resguardando a elas o direito de terem seus próprios membros indicados para a função de se tornarem professores a partir de programas específicos de formação e titulação" (Grupioni, 2000, s/p). In: http://pib.socioambiental.org/pt/c/politicas-indigenistas/educacao-escolar-indigena/introducao

${ }^{58}$ Em relação às escolas indígenas Pankararu no Nordeste, recorremos ao trabalho desenvolvido por Elisa Pankararu, em um dos encontros do COPIPE (Comissão de Professores Indígenas de Pernambuco): "Um dos aspectos que destacamos foi, sem dúvida, a necessidade de adequar a matriz curricular do Estado às disciplinas específicas que incorporamos aos cursos. O fator que torna a nossa prática pedagógica um fato específico é que procuramos articular sempre todas as modalidades de ensino aos cinco eixos do Projeto Político Pedagógico: História, Terra, Identidade, Organização e Interculturalidade. Eixos que norteiam a Educação Escolar Indígena em Pernambuco, pois se trata de um projeto para o Povo. Cada Povo tem o seu projeto, assim, sua identidade própria está reafirmada" (Elisa Pankararu, 2007, p. 39). Isso nos faz refletir a respeito da possibilidade dos cinco eixos temáticos direcionarem práticas pedagógicas para alunos Pankararu em São Paulo. Como as definições aqui citadas mesmo colocam, a questão da identidade está diretamente vinculada à territorialidade, pois a identidade dos povos indígenas nasceria e se constituiria nos territórios. Se os Pankararu não possuem uma terra própria em São Paulo, esses eixos poderiam ser utilizados para uma pedagogia para alunos Pankararu? Pode-se perceber então que a identidade Pankararu da cidade de São Paulo se consolida não apenas em razão de uma territorialidade embora as demandas por um território ainda sejam colocadas pela comunidade -, mas sim em relação à manifestação política da cultura Pankararu e aos direitos indígenas garantidos por lei.
} 
escola não-indígena? E como a temática indígena vem sendo tratada nas escolas nãoindígenas?

Observe-se que o ensino da temática indígena em escolas não-indígenas tem se pautado pelo discurso do multiculturalismo, ou ainda pela diversidade cultural ou pluralidade cultural. Segundo Silva (1999), o multiculturalismo, tendo sido originado nos países do Hemisfério Norte, é um conceito ambíguo, uma vez que pode tanto conduzir a um movimento legítimo de reivindicação de grupos sociais e étnicos presentes no seio dos citados países para terem a representação e o reconhecimento de suas formas culturais garantidos no interior da cultura "nacional", quanto pode ser também uma via para "solucionar" os "problemas" ocasionados pela presença destes grupos nos países do Hemisfério Norte para a cultura nacional dominante. Essa discussão tem a vantagem de trazer à tona a questão de que o multiculturalismo não pode ser considerado sem levar em conta as relações de poder que fizeram com que as mais variadas culturas raciais, étnicas e nacionais convivessem em um mesmo espaço, sendo na, maioria das vezes, silenciadas. Assim, o multiculturalismo arrasta para o campo da política uma compreensão da diversidade cultural que antes estava restrita aos estudos antropológicos, que contribuíram para tornar aceitável a questão de que não se pode estabelecer uma hierarquia entre as culturas humanas.

As diversas discussões que surgiram a respeito do multiculturalismo ${ }^{59}-$ sejam as de cunho "liberal" ou "humanista", cujo discurso nos conduz às questões do respeito, tolerância e convivência pacífica entre as diferentes culturas, sejam as oriundas de uma perspectiva crítica, na qual as diferenças culturais não podem ser concebidas separadas das relações de poder - põem em cheque justamente o cânon do currículo educacional atualmente presente em escolas e universidades.

Stuart Hall (2003) nos lembra que o multiculturalismo, longe de ser uma doutrina já estabelecida, passa, na realidade, por diversos questionamentos. Ele é contestado pela direita conservadora, que defende a pureza e a integridade da nação; pelos liberais, que procuram demonstrar que a defesa da etnicidade e a busca da

\footnotetext{
${ }^{59}$ Stuart Hall faz um levantamento dos diversos tipos de "multiculturalismos": o multiculturalismo conservador que insiste na assimilação da diferença às tradições e costumes da maioria; o liberal, que busca integrar os diferentes grupos culturais à sociedade majoritária, tolerando práticas culturais particularistas no domínio privado; o pluralista, que defende diferenças grupais em termos culturais e proporciona direitos de grupos distintos a diferentes comunidades dentro de uma ordem política comunitária; o comercial, no qual os problemas de diferença cultural serão resolvidos na perspectiva de um consumo privado, sem necessidade de redistribuição do poder e de recursos; o corporativo, que busca "gerenciar" problemas de diferença cultural, visando os interesses do centro; o crítico, que enfoca, o poder, o privilégio e a hierarquia entre os opressores e os movimentos de resistência (cf. Hall, 2003).
} 
diferença ameaçam o universalismo e a neutralidade do Estado liberal, prejudicando portanto a autonomia pessoal, a liberdade individual e a igualdade formal. Dentre as posições de esquerda, os "anti-racistas" colocam a questão de que o multiculturalismo privilegia a cultura e a identidade, deixando de lado as questões econômicas e materiais. Já os radicais argumentam que ele divide, em termos particularistas, uma frente étnica e de classe unida contra a injustiça e exploração (cf. Hall, 2003).

Assim, pareceu-nos pertinente a questão colocada pela antropóloga Paula Montero (1996): por que (e para quem) a diversidade cultural é um problema? Isso porque embora a diversidade cultural seja particularmente familiar a nós e venha se tornando cada vez mais presente em nossa vida cotidiana devido a diversos fatores, a consciência da diversidade cultural também nos coloca diante de diversos dilemas políticos, morais e teóricos de difícil resolução. Montero afirma que:

as diferenças culturais emergem como problemas, sempre que pessoas, grupos ou instituições estão empenhados em integrar em um todo mais ou menos homogêneo - nação, sociedade brasileira, cidadania, etc. - as diferenças de hábitos, visões de mundo e valores distribuídos em um dado espaço geográfico. Assim, se pode dizer que, enquanto as diferenças culturais constituem um fato coetâneo das sociedades humanas, o problema da diversidade só se põe em circunstâncias muito particulares, nas quais um tipo específico de relação social, voltada para a integração das diferenças, prevalece (Montero, 1996, p. 40).

Montero (1996) afirma que, embora a antropologia tenha nascido reconhecendo as diferenças culturais, a disciplina definiu essa abordagem mediante um constructo teórico que se caracteriza pela produção da própria diversidade em um plano conceitual. Assim, a alteridade empírica passou somente a ser significada a partir do momento em que o descentramento cultural se produz no observador, de modo que a diferença acaba por se tornar uma problemática a ser analisada. Nesse sentido, a atuação do antropólogo se pauta pela "produção" da diversidade, sendo a mesma realizada por meio de abordagens teóricas diversas. Destacamse, então, duas visões majoritárias no debate em torno da diversidade: o racionalismo e o relativismo cultural. No caso do racionalismo, podemos observar que: “(...) supõe-se que por detrás da diversidade dos costumes operam procedimentos lógicos, modos de percepção que são universais na condição humana" (Montero, 1996, p. 43); de outro lado, o relativismo cultural, "que nega, ao contrário, a suposição de universalismos e parte do pressuposto de que toda crença só tem significação e validade no interior de seu próprio contexto (Montero, 1996, p. 43). 
Para o ponto de vista racionalista, sem uma suposta universalidade, impossibilitar-se-ia a compreensão dos enunciados de diferenciadas culturas e, conseqüentemente, de se colocar a diversidade como uma temática a ser estudada. De acordo com esta perspectiva, todas as culturas seriam julgadas de acordo com o mesmo critério de racionalidade e a pluralidade cultural seria praticamente pensada segundo uma abordagem que enfatiza o caráter universal do pensamento e ação humanos. O problema que se coloca nessa ênfase é que ela se torna incapaz de explicar os particularismos, "uma vez que eles são reduzidos a variações pouco significativas de estruturas permanentes" (Montero, 1996, p. 43).

O relativismo cultural já defende a tese de que a universalidade, por ser abstrata demais, impede a compreensão de culturas particulares, pressupondo, por exemplo, que a crença só teria razão de ser e significado a partir do contexto no qual ela emerge. Isso exigiria do observador uma posição a mais próxima possível da visão nativa que se queira analisar e compreender.

No entanto, um dilema teórico se coloca, de acordo com Montero (1996): se levarmos a fundo as propostas relativistas, além de rejeitarmos as pretensões universalistas do racionalismo pelo fato de este realizar uma projeção sobre o outro de nosso próprio modo de pensar, também se torna discutível realizar uma análise contextual, pois isso exigiria também a tradução dos valores do outro de acordo com nossos próprios termos, uma vez que o problema de compreensão se impõe a nós e não ao nativo (cf. Montero, 1996).

Isso nos conduz a outra encruzilhada, que se situa como de natureza ética: se uma atitude racionalista diante da diversidade cultural pode nos levar a avaliar a cultura do outro de forma etnocêntrica, uma postura relativista retira do observador a legitimidade para desenvolver uma análise crítica das configurações sociais. Outro exemplo dessa encruzilhada: o mesmo "direito à diferença", como uma conquista política das minorias resultante da assimilação das proposições do relativismo, também vem sendo utilizado por movimentos racistas e da ultradireita para tomar posições cada vez mais excludentes diante das minorias étnicas.

Tudo isso demonstra que a diversidade cultural envolve questões bastante complexas. Observa-se atualmente que a identidade coletiva está se configurando cada vez mais de acordo com parâmetros como etnicidade, cultura, herança e tradição. Desse modo, a identidade étnica vem se mostrando como um problema central, uma vez que situa os Estados diante do "difícil lema de pensar a mediação possível entre o 
universalismo das utopias políticas e 0 particularismo das reivindicações culturais" (Montero, 1996, p. 48). Pode-se dizer que o dilema "universalismo/particularismo" tem recaído intensamente sobre o sistema educacional, exigindo também demandas e respostas de relativa complexidade ${ }^{60}$. Foi a complexidade dessas questões que serviu de estímulo para a realização de uma Semana de Diversidade e Cultura na EMEF Alcântara, organizada em um trabalho conjunto da comunidade Pankararu, universidade e escola, com o intuito de provocar pensamentos a respeito da Lei de obrigatoriedade de ensino de histórias e culturas afro-brasileira e indígena, sem o devido apoio da Secretaria de Educação.

\section{A pluralidade cultural como tema transversal}

De acordo com Silva:

(...) o multiculturalismo nos faz lembrar que a igualdade não pode ser obtida simplesmente através da igualdade de acesso ao currículo hegemônico existente (...). A obtenção da igualdade depende de uma modificação substancial do currículo existente. Não haverá 'justiça curricular', para usar uma expressão de Robert Connell, se o cânon curricular não for modificado para refletir as formas pelas quais a diferença é produzida por relações sociais de assimetria (Silva, 1999, p. 90).

Segundo Lopes da Silva (2001), pode-se encontrar preocupações a respeito da temática da diversidade e pluralidade sócio-culturais nos documentos oficiais do país que traçam as diretrizes das políticas públicas em educação. Tanto que o tema da tolerância, como expressa na Declaração de Princípios sobre a Tolerância (artigo $1^{\circ}$ ),

\footnotetext{
${ }^{60}$ Em relação à questão do multiculturalismo no plano político, Pereira, em seu artigo O Estado Pluriétnico (2002), afirma que a Constituição de 1988 representa uma nítida ruptura em relação aos sistemas constitucionais anteriores pelo fato de reconhecer o Estado brasileiro como pluriétnico, ou seja, não mais caracterizado por pretensas homogeneidades, que seriam garantidas tanto por meio da tentativa de submeter os diferentes grupos étnicos presentes em território nacional a uma assimilação quanto por meio de uma forçada invisibilidade. Ainda de acordo com a autora, a visão de Estado-nação orientada por uma lógica unitária e indivisível e pelo conceito de soberania tornou-se obsoleta ao ser confrontada com as questões e pressões geradas pela pluralidade sócio-cultural presente no território nacional e pela influência direta do capital transnacional que retirou do Estado a capacidade de previsão e controle de aspectos predominantes da vida social (Pereira, 2002, s/p). O impacto dessas alterações constitucionais é destacado por Lopes da Silva (2001) ao se referir à mudança de postura do Estado brasileiro diante da educação escolar indígena e também a inclusão da temática da pluralidade cultural nos PCN, resultante também da mobilização política que congregou indígenas e não-indígenas, desde a década de 1970, para que houvesse a contemplação jurídica de diversos direitos reivindicados pelos povos nativos.
} 
está contemplado nos Parâmetros Curriculares Nacionais $(\mathrm{PCN})^{61}$ por meio da introdução de um "tema transversal"62 às disciplinas escolares específicas e que, portanto, deve ser contemplada por elas: seria o tema da "Pluralidade Cultural".

Cabe explorar um pouco melhor a questão da Pluralidade Cultural, como disposto na introdução do PCN - Temas Transversais ( $5^{\mathrm{a}}$ a $8^{\mathrm{a}}$ séries). $\mathrm{O}$ texto introdutório (1998) explica que a temática da Pluralidade Cultural está relacionada ao conhecimento e à valorização de características étnicas e culturais dos diversos grupos sociais inseridos no território brasileiro, às desigualdades sócio-econômicas presentes nesse mesmo território e à crítica às relações sociais discriminatórias e excludentes que permeiam a sociedade brasileira, buscando-se, desse modo, auxiliar o aluno a reconhecer o Brasil como um país complexo e multifacetado. Ainda deixa explícito que reconhecer e valorizar as diferenças étnicas e culturais não significa necessariamente que se deva aderir aos valores dos outros, mas sim respeitá-los como uma expressão da diversidade, "respeito que é, em si, devido a todo ser humano, por sua dignidade intrínseca, sem qualquer discriminação" (PCN, 1998, p. 121). O texto ainda procura realizar uma distinção entre diversidade cultural e desigualdade social. Para isso, explana que as culturas são "produzidas pelos grupos sociais ao longo de suas histórias, na construção de suas formas de subsistência, na organização da vida social e política, nas suas relações com o meio e com outros grupos, na produção de conhecimentos etc. A diferença entre culturas é fruto da singularidade desses processos em cada grupo social" (PCN, 1998, p. 21). E define que a desigualdade social seria produzida na

\footnotetext{
${ }^{61}$ No texto de apresentação do volume Parâmetros Curriculares Nacionais - Temas transversais $\left(5^{\mathrm{a}}\right.$ a $8^{\mathrm{a}}$ séries), de autoria do então Ministro da Educação e do Desporto, Paulo Renato Souza, estão assim descritos os Parâmetros Curriculares Nacionais: "Os Parâmetros Curriculares Nacionais foram elaborados procurando, de um lado, respeitar diversidades regionais, culturais, políticas existentes no país e, de outro, considerar a necessidade de construir referências nacionais comuns ao processo educativo em todas as regiões brasileiras. Com isso, pretende-se criar condições, nas escolas, que permitam aos nossos jovens ter acesso ao conjunto de conhecimentos socialmente elaborados e reconhecidos como necessários ao exercício da cidadania" (Souza, 1998, p. 5). Nesse sentido, observa-se que o "eixo vertebrador da educação escolar" (PCN, 1998, p. 23), uma preocupação constante dos PCN, seria a temática da cidadania, como está explicitado já no início do texto de apresentação: "O papel fundamental da educação no desenvolvimento das pessoas e das sociedades amplia-se ainda mais no despertar do novo milênio e aponta para a necessidade de se construir uma escola voltada para a formação de cidadãos" (Souza, 1998, p. 5). A cidadania seria um dos fundamentos do Estado Democrático de Direito, como exposto no artigo $1^{\circ}$ da Constituição Federal.

${ }^{62}$ De acordo com o PCN (1998), os Temas Transversais possuem uma natureza diversa das áreas denominadas convencionais. Seriam processos que estariam sendo vividos intensamente em nível social, comunitário, familiar e individual no cotidiano e que são temáticas urgentes que questionam sobre a vida humana e a realidade e que exigem transformações tanto em nível social como individual, demandando ensino e aprendizagem dos conteúdos relacionados a estas dimensões. Argumenta-se também que, devido à sua complexidade, nenhuma das áreas convencionais de ensino seria suficiente para explicar tais processos, pois ela atravessa os diferentes campos de conhecimento. Os Temas Transversais tratariam, portanto, dos seguintes temas: Ética, Saúde, Meio Ambiente, Orientação Sexual, Pluralidade Cultural e Consumo.
} 
relação entre dominação e exploração socioeconômica e política. Tendo explicitado isso, o texto procura esclarecer que não se pretende menosprezar a questão da desigualdade social na proposta de conhecer e valorizar a pluralidade cultural brasileira. Na realidade, ao se tratar do tema da discriminação, não seria possível compreendê-lo sem nos referirmos ao contexto social no qual ela ocorre e à estrutura autoritária que delineia a sociedade. Assim, "as produções culturais não ocorrem 'fora' de relações de poder: são constituídas e marcadas por ele, envolvendo um permanente processo de reformulação e resistência" (PCN, 1998, p. 21). Desse modo, tanto a desigualdade social como a discriminação atuam em conjunto no que se denomina "exclusão social", que se caracteriza pela impossibilidade de indivíduos e grupos terem acesso a bens materiais e culturais produzidos pela sociedade e de participar na gestão coletiva do espaço público, o que seria um pressuposto da democracia. Cabe então a afirmação de que o Brasil seria um país regido por privilégios, que se baseiam em discriminações e preconceitos de todo tipo: sócio-econômico, étnico e cultural. "Em outras palavras, dominação, exploração e exclusão interagem; a discriminação é resultado e instrumento desse complexo de relações" (PCN, 1998, p. 21).

Assim, o texto esclarece que a abordagem da Pluralidade Cultural não tem como objetivo o esquadrinhamento da sociedade em grupos culturais fechados, mas sim "o enriquecimento propiciado a cada um e a todos pela pluralidade de formas de vida, pelo convívio e pelas opções pessoais, assim como o compromisso ético de contribuir com as transformações necessárias à construção de uma sociedade mais justa" (PCN, 1998, p. 122). Reconhecer e valorizar a diversidade cultural, portanto, seria uma forma de atacar um dos mecanismos de discriminação e exclusão, que seriam obstáculos para o pleno exercício da cidadania para todos e para toda a nação (PCN, 1998). Sem dúvida, o texto nos mostra grandes avanços no sentido de incluir a diversidade sócio-cultural em currículos anteriormente marcados por um discurso homogeneizante no que se refere à cultura escolar, desprezando até então o caráter multiétnico da sociedade brasileira. Mas as dúvidas em relação às propostas colocadas pelo $\mathrm{PCN}$ surgem no que se refere à sua implementação e à sua eficácia ao combate da exclusão social dos grupos minoritários e mesmo em relação a alguns de seus pressupostos teóricos.

Segundo Lopes da Silva (2001), apesar de todos esses avanços, os PCN demonstram as dificuldades existentes na absorção plena das noções de pluralidade cultural e respeito à diferença no plano pedagógico. Isso porque se verifica a existência de inconsistências entre o discurso sobre a pluralidade cultural e as concepções que 
estão subjacentes às sugestões de propostas pedagógicas presentes nos próprios PCN. Desse modo, a despeito de todo o espaço concedido à questão da pluralidade cultural nos PCN, o que se observa, em termos práticos, é que a temática recebe um "tratamento tímido, revelador de uma 'meia conversão', mais um reconhecimento da impossibilidade de sua desconsideração no âmbito nacional e escolar do que a necessária revolução de mentalidade que o tema deveria desencadear e sem a qual o cristalizado monumento de intolerância constituído pelo racismo e pela discriminação étnica e cultural tenderá, nas escolas, a se manter inabalado" (Lopes da Silva, 2001, p. 122). Como indicativo dessas inconsistências, Lopes da Silva (2001) compara o tratamento teórico dado ao tema com a "aplicação pedagógica" proposta. Cita como exemplo, no PCN, o roteiro da proposta pedagógica de se estudar uma comunidade indígena (PCN, vol. 5, pp. 55-57) faz menção às "crenças, lendas e mitos de origem”, mas exclui a história dos próprios indígenas, pois se propõe que sejam estudadas as transformações sofridas pela comunidade indígena a partir de seu contato com outros povos não-indígenas. Com base nisso, pode-se presumir que os PCN consideram que os processos históricos são deflagrados de fora e que, então, a historicidade não é um atributo pertencente aos universos sócio-culturais indígenas, que seriam então “sociedades sem história". Desse modo, não se efetiva, na realidade, uma crítica aos conceitos e aos pressupostos do evolucionismo clássico que ainda perdura no senso comum brasileiro e na cultura escolar, com o perigo de não se concretizar o esforço de incorporar adequadamente os indígenas na cultura escolar (Lopes da Silva, 2001).

Lopes da Silva (2001) também alerta para o fato da pluralidade cultural ser inserida nos PCN como um "tema transversal", o que pode ser um indicativo de uma adesão apenas "parcial" às concepções de diversidade apresentadas por parte do documento oficial. De acordo com as definições dos "temas transversais" apresentadas pelo Ministério da Educação nos PCN, é citado: "o compromisso com a construção da cidadania pede necessariamente uma prática educacional voltada para a compreensão da realidade social e dos direitos e responsabilidades em relação à vida pessoal, coletiva e ambiental" (PCN, vol. 8, p.15). A transversalidade seria então uma das formas educativas adotadas para abranger a necessidade dessa compreensão da realidade social, não implicando necessariamente, para isso, na criação de novas disciplinas.

Os objetivos e conteúdos dos Temas Transversais devem ser incorporados nas áreas já existentes e no trabalho educativo da escola. (...) Amplos o bastante para 
traduzir preocupações da sociedade brasileira de hoje, os Temas Transversais correspondem a questões importantes, urgentes e presentes sob várias formas, na vida cotidiana (PCN, vol. 8, p.15).

O questionamento que se apresenta é se os Temas Transversais se referem a questões tão importantes, atuais e que mereçam uma atenção tão urgente, como colocado nas definições do PCN, por que colocá-los de forma tão tímida e titubeante, à margem das disciplinas curriculares existentes e dispostas praticamente como um dispositivo não-obrigatório.

Para elucidar essa questão, consideramos interessante realizar uma pequena genealogia das disciplinas que compõe o currículo oficial. Segundo Montserrat Moreno (1998), se rastrearmos as origens das disciplinas que fazem parte do currículo oficial (Língua, Matemática, História, Geografia e outros), observaremos que elas provêm de núcleos de interesses intelectuais dos quais se ocupavam os pensadores gregos clássicos, considerados os precursores da ciência ocidental. Nesse caso, não podemos esquecer que as grandes questões que ocupavam a mente destes pensadores - que compunham uma elite no interior de uma sociedade também marcada por uma alta hierarquização - eram distanciadas das que surgiam das demandas da vida cotidiana, que estavam a cargo da maioria da população, composta em boa parte por mulheres e escravos. Essas grandes questões, embora primordiais para os grandes passos dados no desenvolvimento do pensamento ocidental, seriam fruto da seleção dos saberes possíveis e disponíveis na época, configurando-se também como um instrumento de poder. Logicamente, novas disciplinas surgiram e os campos intelectuais se ampliaram consideravelmente, mas os campos de interesse dos pensadores gregos ainda ditam, em sua essência, as matérias curriculares existentes no currículo escolar.

De acordo com Moreno (1998), os conhecimentos, raciocínios e questões científicas que são transmitidos entre as gerações carregam em seu bojo também as atitudes e preconceitos que os circundavam. $\mathrm{O}$ ensino então não consiste apenas em transmitir a ciência e a cultura, mas também suas grandezas e misérias. Ou seja, "nossos sistemas de pensamento não são independentes de sua história” (Moreno, 1998, p. 30).

Tudo isso leva ao questionamento de que:

se os temas daquilo que chamamos de 'ciência' são os únicos importantes entre todos os possíveis, ou se são fruto de uma conjuntura histórico-cultural que 
certamente nos proporcionou grandes sucessos a desfrutar coletivamente, mas que nos fez relegar outros grandes temas fundamentais para a sobrevivência da humanidade (...). Aquelas questões que priorizamos no ensino, por razões históricas, não estarão nos encerrando em torres de marfim que nos impedem ver as penas e sofrimentos de grande parte da humanidade - dentro da qual encontrase a maioria da população escolar - à qual estas prioridades não correspondem? (Moreno, 1998, p. 34).

Torna-se evidente que, se são mantidas certas prioridades culturais, isso ocorre porque ainda se mantém em vigor as atitudes que as originaram. Mas se as circunstâncias históricas demandam mudanças em relação a essas atitudes, então o ensino também deveria refletir essa tendência. Desse modo, o que Moreno propõe seria:

retirar as disciplinas científicas de suas torres de marfim e deixá-las impregnar-se de vida cotidiana, sem que isto pressuponha, de forma alguma, renunciar às elaborações teóricas imprescindíveis para o avanço da ciência. Se considerarmos que estas duas coisas se contrapõem, estaremos participando de uma visão limitada, que nos impede contemplar a realidade de múltiplos pontos de vista (Moreno, 1998, p. 35).

Para Moreno, se os temas transversais se tornarem somente novos conteúdos a serem acrescentados ao currículo oficial, eles apenas sobrecarregarão os programas didáticos e o trabalho docente, pois a nova temática seria tratada com velhos procedimentos, eliminando assim todo o tipo de inovação que ela possa trazer (cf. Moreno, 1998).

Ana Canen (2000), ao realizar estudos sobre os PCN, questionou a viabilidade de se tratar a pluralidade cultural como tema transversal, com o receio de que a "impregnação" da proposta nas diversas disciplinas seja tão tênue a ponto de se tornar invisível. O risco seria de a conscientização acerca da educação multicultural, sem uma devida e aprofundada ênfase no interior de todas as áreas, se reduza a apenas um "imperativo moral", que seria aceito pelo corpo docente no currículo formal, mas que não seria efetivamente implementado nas práticas curriculares vivenciadas. Isso pode ser observado, de fato, na organização da Semana de Diversidade e Cultura, quando é possível notar o escasso comprometimento dos professores em relação à pluralidade cultural, tratada como algo sem a devida importância. 
Além disso, segundo Canen (2000), apesar de todas as conceituações teóricas, as tentativas de reconhecimento da pluralidade identitária de grupos sócio-culturais e a busca da superação da homogeneização cultural, as propostas não parecem incluir docentes e discentes na efetiva discussão das questões colocadas. Trata a pluralidade cultural distanciando-a da realidade concreta do cotidiano escolar, limitando-se a narrar fatos históricos ou apresentando ritos e costumes referentes aos grupos destacados, como numa espécie de "feira ou desfile cultural". "Enfatiza-se o 'outro', sem que se promova a conscientização da pluralidade cultural e dos estereótipos a ela relacionados, dentro do próprio espaço escolar e das práticas sociais mais amplas, em uma perspectiva intercultural crítica" (Canen, 2000, p. 143). Uma apresentação realizada dessa maneira conduz à idéia de grupos culturais que sejam puros e locais, reforçando novamente, em outros termos, uma homogeneidade cultural, além de desprezar os aspectos dinâmicos e conflituosos e as transformações pelas quais os grupos culturais desenvolvem identidades híbridas (Canen, 2000). Um claro exemplo de todo esse processo são os alunos Pankararu, que apresentando uma "identidade híbrida", resultante de diversas transformações culturais e sociais pelas quais seu grupo étnico atravessou e que está muito distante de uma representação de um grupo cultural puro e homogêneo, como o que é geralmente apresentado pelos livros didáticos e reforçado em salas de aula. $\mathrm{O}$ resultado disso é evidentemente uma negação da identidade indígena desses alunos na escola, uma vez que eles não se encaixam nas categorias pré-estabelecidas de representação dos indígenas tão predominante na escola.

Mesmo quando as proposições do PCN tratam a respeito do preconceito, o discurso adotado aborda a questão com base em um tom individual, não permitindo que se aflore a consciência de que a origem das discriminações que calam as vozes dos grupos sócio-culturais está localizada nas estruturas de poder que induzem às práticas pedagógicas que dão primazia aos padrões culturais dominantes.

Para Valente (2003), os pressupostos que guiam os PCN e muitos dos estudos a respeito da temática da diversidade cultural nas escolas estão baseados na premissa de que a escola seria um espaço de troca, diálogo e convivência. No entanto, a pesquisadora aponta para a questão de que a escola tem sido, na realidade, um espaço de imposição, monólogo e certezas. É essa ação homogeneizadora que tem gerado reações e reivindicações de respeito à diferença, na medida em que esta ação é uma expressão da sociedade majoritária e, portanto, atravessada também pelos conflitos e contradições inerentes a ela. 
Torna-se necessário que os educadores agucem a sua percepção do que ocorre no exterior da escola. "Desse modo, os sujeitos engajados nesse processo poderão ter condições para avaliar, no interior da própria contradição, a possibilidade de construção da síntese que implique a compreensão de que a escola pode e deve mudar para responder aos desafios da realidade" (Valente, 2003, p. 17).

De certo modo, o trabalho de pesquisa e intervenções realizado em salas de aula, envolvendo professores e pesquisadores, permitiu a eles vislumbrar o quanto a escola não tem propiciado um real diálogo entre alunos e professores e o respeito à diferença, além de auxiliá-los a observar a ação homogeneizadora da escola em relação aos alunos, sendo que estes opõem-se à essa ação por meio de diversos mecanismos de resistência, ocasionando então conflitos nas salas de aula e minando qualquer forma de autoridade do professor diante dos alunos. A abertura ao "outro", o aluno, pode ser o caminho pelo qual o corpo docente poderia repensar e transformar suas visões de mundo e suas atuações pedagógicas, além de transformar, em seu interior, a própria cultura escolar, tão avessa ao que é diferente.

\section{A elaboração do questionário}

Para um maior conhecimento a respeito dos alunos que freqüentam a EMEF Alcântara, foi elaborado inicialmente um questionário (Anexo I), juntamente com o conjunto de professores e pesquisadores participantes do projeto "Cultura escolar $\mathrm{x}$ culturas juvenis", que pudesse também contemplar as condições sociais, familiares e as manifestações culturais, os gêneros musicais e as necessidades e ansiedades dos alunos em relação ao futuro. Cientes da existência da comunidade indígena Pankararu no entorno da escola e, conseqüentemente, de alunos da etnia Pankararu presentes nas salas de aula, foi incluída nesse questionário a pergunta: "Você conhece os Pankararu? O que sabe sobre eles?", de modo que pudéssemos identificar, na fala dos alunos Pankararu existentes na escola, a visão que tinham a respeito de si próprios e de sua cultura e também a concepção que os demais alunos nutriam a respeito dos jovens Pankararu.

\section{A metodologia de análise do questionário}


Uma vez elaborado o questionário e com a sua aplicação em quatro classes de $7^{\mathrm{a}}$ série e em três classes de $8^{\mathrm{a}}$ série em abril de 2007, o passo seguinte seria elaborar uma metodologia de análise dos questionários coletados. Essa metodologia ${ }^{63}$, delineada pela Profa. Mônica do Amaral, buscava realizar uma abordagem qualitativa dos questionários, tendo sempre um "olhar atento ao contexto específico da escola pesquisada e um olhar voltado para as tendências cada vez mais fluidas da cultura contemporânea e de como estas se mesclam com nosso passado, cuja herança conserva os traços retrógrados que acompanharam desde o início o avanço do projeto de modernização brasileira" (Amaral, 2007, p. 10).

Segundo Amaral (2007), a idéia fundamental do questionário era observar em que medida a razão reinante na cultura escolar, sustentada pelo corpo docente e administrativo da escola, poderia ser rompida e renovada por dentro a partir do contato com o que há de mais crítico e transformador das culturas juvenis, portadoras das vozes dissonantes no interior da escola, marginalizadas, mas potencialmente críticas. Seria importante observar também se as culturas tradicionais, como as do Pankararu, estavam sendo excluídas da cultura escolar por uma razão instrumental ${ }^{64}$ predominante na escola.

\footnotetext{
${ }^{63}$ A metodologia tomou como base um artigo sobre o método proposto pela pesquisadora e docente da UFRGS na área de psicologia e educação, Profa. Dra. Clary Milnitsky-Sapiro (2005/2006), que propõe uma forma de análise do discurso do adolescente sobre a escola e suas vivências extra-escolares (familiares e culturais), respeitando suas próprias concepções. Sapiro sugere ainda estudos que possam percorrer o entrelaçamento dos caminhos de cada sujeito com outros, por meio de recortes do contexto social . A autora defende a idéia de que é necessário procurar apreender a relação indivíduo-sociedade afastada de qualquer compreensão psicologizante ou sociologizante. Desse modo, Sapiro sugere basicamente que seja feita uma descrição de cunho etnográfico de modo a respeitar a linguagem da comunidade pesquisada sem partir de categorias temáticas a priori, mas, ao contrário, procurando depreendê-las do próprio discurso dos sujeitos pesquisados, atentando para as 'variações culturais, a partir da compreensão do significado da própria linguagem do grupo, buscando compreender seus significados no contexto'. Um registro etnográfico que seria feito tanto a partir dos registros do diário de campo, como a partir dos depoimentos dos indivíduos cuja realidade estivesse sendo pesquisada (Sapiro, 2006, s/p). Inspirada também pela psicanálise, Sapiro propõe três momentos dessa análise do conteúdo dos discursos: primeiro, uma leitura de todo o material (documentos, registros, questionários, transcrições de entrevistas, etc.), como faria o analista, guiado por uma 'atenção flutuante', ou seja, atentos, não somente para o discurso manifesto, mas, também, para o que entendemos ser o material inconsciente; depois, identificando 'transições significativas', ou seja, mudanças temáticas; para, em um terceiro momento, apanhar as unidades de significado que seriam as categorias propriamente ditas (Sapiro, 2006, s/p). A análise do questionário foi realizada com a participação dos professores envolvidos no Projeto, que puderam assim reconhecer com mais propriedade os alunos aos quais dão aulas.

${ }^{64}$ Segundo Max Horkheimer, "tendo cedido em sua autonomia, a razão tornou-se um instrumento. No aspecto formalista da razão subjetiva, sublinhado pelo positivismo, enfatiza-se a sua não-referência a um conteúdo objetivo; em seu aspecto instrumental, sublinhado pelo pragmatismo, enfatiza-se a sua submissão a conteúdos heterônomos. A razão tornou-se algo inteiramente aproveitado no processo social. Seu valor operacional, seu papel de domínio dos homens e da natureza tornou-se o único critério para avaliá-la" (Horkheimer, 1976, p. 28).
} 


\section{A síntese da avaliação dos questionários}

Ao realizarmos uma análise detalhada dos questionários com base na metodologia acima descrita, tivemos um amplo quadro da realidade social e cultural vivida pelos alunos dessa escola, que foi posteriormente descrito no Relatório Científico Parcial do Projeto de Pesquisa Culturas Juvenis x Cultura Escolar (2007), elaborado pela Prof ${ }^{a}$. Mônica do Amaral, com base na análise das respostas dos questionários por parte dos alunos, intervenções em sala de aula e discussões com os professores. Embora seja interessante descrever todo o rico retrato da escola obtido após esse levantamento, traremos apenas alguns excertos do Relatório Científico (2007) com o intuito de delinear nosso campo de trabalho e nos concentrarmos apenas nos assuntos pertinentes ao presente trabalho de pesquisa de Mestrado. O questionário tratou também da inserção da comunidade Pankararu no âmbito da escola em questão.

\section{Origens}

Em relação às origens dos alunos, as análises do Relatório Científico (Amaral, 2007) nos mostram que cerca de metade dos alunos pesquisados nasceu na cidade de São Paulo. Outra parcela dos alunos veio de outras regiões do Brasil e nasceu em cidades das regiões Norte e Nordeste, além do Estado de Minas Gerais. A maior parte das famílias é oriunda das regiões Norte e Nordeste, embora encontremos membros da comunidade de outras regiões, como dos estados de Minas Gerais, Rio Grande do Sul, Paraná, Mato Grosso e São Paulo. A maioria dos alunos conhece muito bem as origens de suas famílias, principalmente os que são do Nordeste.

Esses dados são importantes, pois apresentam um quadro em que grande parte dos alunos ou nasceu no Nordeste ou descende de pais que nasceram do Nordeste. Isso condiz com a realidade vivida pelos indígenas Pankararu, que vieram de Brejo dos Padres (município de Tacaratu, Pernambuco) para São Paulo, estabelecendo suas raízes na comunidade do Real Parque e em outros bairros da cidade de São Paulo. São os filhos dos imigrantes Pankararu que freqüentam a escola, além de crianças e adolescentes Pankararu que continuam a migrar do Nordeste para cá em um fluxo contínuo, em virtude das dificuldades de subsistência ainda encontradas no Brejo dos Padres. Não é raro encontrarmos alunos que chegaram recentemente do Nordeste e se matricularam na escola. 


\section{Organização familiar}

Conforme observado no Relatório Científico (Amaral, 2007), o que podemos vislumbrar a respeito desse tópico é que o núcleo familiar se alterou, não correspondendo mais à imagem tradicional de uma família formada por pai, mãe e filhos. Pode-se notar nas respostas dos alunos que, na ausência do pai, é a mãe que passa a assumir o sustento do lar, o cuidado e a educação dos filhos. A imagem paterna, em conseqüência de sua ausência na família, é vivida como algo tão distante a ponto de se apagar da memória do jovem a própria origem paterna.

Em relação à convivência com a família, muitos moram juntos na mesma casa: pais, avós, primos, tios, irmãos ou mãe e filhos de diferentes pais (muitas vezes, fruto da recomposição familiar como resultado da migração do Nordeste para São Paulo, apontando uma reconfiguração da chamada família ampliada). Os novos vínculos familiares entre pais, mães, padrastos e madrastas, para alguns, trazem segurança, mas para outros geram situações conflituosas. "Somos humildes, porém unidos" - essa era uma frase recorrente entre os alunos para expressar sentimentos, como solidariedade na alegria e na tristeza entre os seus e na comunidade.

Em pesquisas posteriores, notamos que, entre os alunos da etnia Pankararu, a configuração familiar também tem se alterado, pois observamos situações em que a mãe assume o sustento familiar, cujos filhos, que convivem em uma mesma residência, são de pais diferentes, que estão ausentes. Em outra situação, uma aluna, cujos pais são falecidos, convive com irmãos que não compartilham da etnia Pankararu, uma vez que a descendência indígena da aluna veio por parte do pai. Pudemos observar ainda que, no seio da comunidade Pankararu do bairro Real Parque, os núcleos familiares são diversos e complexos.

\section{A escola e as suas representações}

Segundo o Relatório Científico (Amaral, 2007), a escola é vista pelos alunos pesquisados como algo essencial em suas vidas, no entanto eles não compreendem muito bem qual é o sentido do aprendizado que lhes é oferecido. Sua importância é sempre remetida a um futuro distante, o que demonstra uma forte idealização do papel da escola em suas vidas, como pode ser visto em falas, como, por exemplo: “(A escola) 
representa o saber. O que seria dos seres humanos sem ela?". De outro lado, eles se deparam com a dura realidade da escola sem professores, um problema crônico em particular dessa unidade, como se pode depreender do depoimento de um aluno quando perguntado sobre o que poderia ser melhorado no ensino: "Os professores dando aulas e a diretora contratando professores". Nota-se, então, que a escola sonhada é muito diferente da escola vivida. Apesar de valorizarem muito o papel da escola para o seu futuro, levantam críticas bastante pontuais ao seu funcionamento atual.

Outros vêem na escola uma possibilidade concreta de inserção no mercado de trabalho, embora não saibam de que forma isso poderia ocorrer. Como prova disso, alguns dos alunos solicitaram por parte da escola o aprendizado de posturas adequadas para arrumarem emprego. Isso nos remete ao trabalho teórico realizado por Bowles e Gintis (1990), que discutem o fato de que a escola, muitas vezes, assume o papel de preparação de "bons trabalhadores" que irão assumir determinadas funções no sistema de produção capitalista. Com essa demanda, a escola fica no dilema de proporcionar uma formação técnica e utilitarista ou uma formação mais ampla e humanística, além de ter de lidar com diversos problemas estruturais e pedagógicos. Os alunos Pankararu, tantos os que nasceram em um ambiente urbano como os que chegaram das terras indígenas do Nordeste, vivem no contexto da metrópole e também buscam inserção no mercado de trabalho, assim como na sociedade.

Pudemos observar também, a partir dos questionários, uma dificuldade significativa na aquisição da linguagem escrita por parte dos alunos. Como obstáculos para o sucesso do letramento, verificou-se a existência de classes numerosas e desiguais (que teria como uma das razões a ausência de pré-requisitos para cada série) e a dificuldade do professor em lidar com o aluno analfabeto funcional.

É interessante observar que os alunos indígenas Pankararu deparam-se com uma escola que enfrenta problemas estruturais e pedagógicos e que não oferece as condições necessárias para um letramento adequado, além de muitas vezes excluir ou não levar em conta a diversidade cultural existente na comunidade por ela atendida, em especial as culturas indígenas. Com isso, a inserção dos alunos na sociedade fíca severamente prejudicada.

\section{O conceito de cultura por parte dos alunos}


Por meio das análises do Relatório Científico (Amaral, 2007), pudemos também observar como os alunos conceituam a cultura. Notou-se que as concepções a respeito de cultura, por parte dos alunos, são variadas e diferem muito de uma concepção do senso comum.

Eles identificam também como cultura determinados movimentos culturais como: danças (brasileiras, indígenas, black, axé, forró, etc.); grupos musicais (heavy metal, black, funk, rap, pagode, show de samba); cursos (oficinas de informática, inglês, grafite, teatro, multimídia); esportes como futebol e tênis; lan-house (é uma forma de comunicação e pesquisa) e visitas a orfanatos. Entre as danças, as afro-brasileiras e o hip-hop são os mais citados. Outros alunos identificam a cultura com alguns grupos étnicos, de modo que os Pankararu foram citados como uma "tribo cultural".

Muitos dos alunos confundem cultura com os espaços propiciadores de cultura, como certas ONGs que atuam na região proporcionando oficinas de dança, música e de conhecimento técnico, como informática.

Podemos presumir resumidamente que a cultura, na concepção dos alunos, significa uma espécie de entrada na vida pública (cf. Amaral, 2007). Essa constatação nos remete a Michel de Certeau que, em sua obra Cultura no plural (2005), afirma que houve uma transformação da relação da cultura com a sociedade, uma vez que a cultura não está mais reservada a um grupo social e não se configura mais como uma propriedade de determinadas especialidades profissionais, como professores e advogados. Em suma, “ela não é mais estável e definida por um código aceito por todos" (Certeau, 2005, p. 104).

Certeau (2005) cita René Kaës, que aplicou um questionário a respeito de cultura a operários franceses e assim descreveu a expectativa destes em relação à escola e à cultura:

Uma escola que constitua um lugar de encontro e de aprendizagem da vida social, microcosmo e prefiguração da sociedade da vida adulta e lugar de preparação prática e teórica para a vida cotidiana, em particular a do trabalho. A maioria dos operários vai em busca daquilo que lhes parece mais urgente: garantia de mobilidade e a facilidade nas relações sociais, sair da indiferenciação e da intercambialidade profissional (Kaës, Apud Certeau, 2005, p. 104). 
Desse modo, os alunos, uma vez submetidos a grades curriculares que não lhes proporcionam sentido nem em função dos desafios sociais que enfrentam, nem em função do que o futuro parece ou pode lhes reservar, não percebem no ensino oferecido um valor, sequer, de instrumentalidade social e cultural (cf. Certeau, 2005).

Tal panorama, embora pertencente a um contexto social francês, não deixa de apresentar similaridades com o que temos observado entre os alunos da escola pesquisada, na qual observamos outra conceituação de cultura por parte dos alunos, visando justamente essa instrumentalidade social e cultural.

Uma questão a ser pensada é se os alunos da etnia Pankararu não se encontram em um dilema entre optar por algo que lhes proporcione a citada "instrumentalidade social e cultural", ou por uma cultura tradicional que os remeta às suas raízes étnicas, mas que não configura como uma aspiração a ser reconhecida ou mesmo valorizada pela razão instrumental, a não ser como "folclore" (como uma cultura fixada no tempo).

\section{A existência de alunos Pankararu na escola}

Entre os alunos pesquisados, identificamos que muitos deles desconhecem por completo a existência de indígenas Pankararu na comunidade e conseqüentemente da cultura trazida por eles (cf. Amaral, 2007). É um fato que requer maior atenção, pois os Pankararu possuem uma população considerável dentro da comunidade do Real Parque e não são poucos os alunos da etnia que freqüentam a escola. O que podemos observar em todas essas falas e representações dos alunos é que há uma visão fragmentada a respeito dos Pankararu, provavelmente pelo fato de estes habitarem em abrigos e conjuntos habitacionais espalhados na comunidade e não disporem de um espaço próprio onde possam viver juntos e realizar suas práticas rituais. Outro fator é que os Pankararu são desprovidos de uma forte contrastividade cultural (Oliveira Filho, 1998) em relação à sociedade majoritária, por não possuírem sinais diacríticos evidentes que os identifiquem claramente como indígenas. Não se pode deixar de citar, em razão do que foi exposto também, os obstáculos para a auto-afirmação de uma identidade étnica indígena em razão do temor ao preconceito e discriminações.

No entanto, alguns alunos demonstraram conhecê-los de perto, na convivência da escola e na comunidade, demonstrando não só ter certo contato com suas danças e costumes, como os que ocorrem no Dia do Índio, conhecendo, portanto, não apenas as 
suas origens, como sua importância no Real Parque, além de reconhecerem as suas difíceis condições de vida dessa comunidade indígena. Observemos algumas das representações sobre essa comunidade:

"Eles moravam em outro lugar e foram morar no Real";

"São índios que vieram de sua terra no Recife para conseguir sustento aqui em São Paulo" "65;

"Sei que eles foram os primeiros a vir para cá... e quando eles vieram era tudo mato, e lá onde eles viviam era muito difícil”.

Nessas falas, observa-se a consciência dos alunos a respeito das duras condições de vida dos Pankararu. Eles possuem a idéia de que convivem com os Pankararu na comunidade, mas pouco sabem a respeito de suas origens. Além disso, pudemos observar que a existência de alunos Pankararu nas salas de aula e de uma comunidade no entorno da escola não era ignorada pelo corpo docente da EMEF. Na realidade, a chegada de indígenas Pankararu ao Real Parque é muito anterior à fundação dessa escola. No entanto, o grupo de pesquisa da Universidade se espantou com o fato de que, mesmo aproximadamente 22 anos depois da fundação da escola, o corpo diretivo e docente da EMEF não havia realizado nenhum trabalho específico e permanente com a comunidade Pankararu. Pudemos apenas observar que a temática indígena na escola era abordada somente nas comemorações do Dia do Índio, evidenciando-se que os trabalhos realizados a respeito dos indígenas eram bastante marcados pela estereotipia.

De acordo com o relato dos professores mais antigos, certas atividades realizadas com os alunos Pankararu durante um determinado período, há aproximadamente 10 anos, foram bastante pontuais e não tiveram continuidade, o que demonstra que a preocupação com a temática não estava inserida na cultura escolar ou no interior de um projeto político-pedagógico na escola ${ }^{66}$, nem houve tampouco uma mobilização por parte do corpo diretivo e docente no sentido de se realizar uma pesquisa ou um trabalho junto à comunidade Pankararu. Em reuniões com os professores participantes do projeto, foi questionado se os $\mathrm{PCN}$, em especial o tema transversal "Pluralidade cultural", já haviam sido tema de discussão nas JEIs ou em outras atividades pedagógicas, ou que tivesse havido uma preocupação por parte do

\footnotetext{
${ }^{65} \mathrm{Na}$ verdade, eles vieram das proximidades de Tacaratu, interior de Pernambuco, e não da capital pernambucana.

${ }^{66}$ Até o momento da pesquisa, nenhum projeto político-pedagógico havia sido, de fato, elaborado na EMEF Alcântara.
} 
corpo docente de se conhecer com maior profundidade a realidade e a cultura dos indígenas Pankararu no Real Parque. Os professores comentaram que um trabalho incipiente havia sido feito nesse sentido e os argumentos para que isso não tivesse ocorrido giravam em torno dos problemas estruturais da escola, incluindo também o elevado grau de animosidade dos professores com a diretoria da escola. Pode-se confirmar, com isso, o receio dos diversos especialistas de que a abordagem da pluralidade cultural como tema transversal, passados aproximadamente 11 anos após a sua proposição, se tornara de fato um "imperativo moral" ou um item apenas "interessante", mas não obrigatório, a ser discutido com os alunos e que os temas transversais passaram a ser vistos como um peso a mais nos programas e na tarefa do corpo docente e por isso descartado como proposta pedagógica. Nesse sentido, todo o esforço de se inserir discussões a respeito da pluralidade cultural na escola tem redundado em fracasso, como temos visto na EMEF Alcântara.

\section{Uma visão estereotipada dos indígenas}

Para compreendermos essa temática, um dos passos possíveis seria a análise da questão do currículo escolar e compreender que a seleção dos saberes que irão compor um determinado modelo de currículo está relacionada com questões de poder e de hegemonia de classes.

Segundo Giroux (1983), de acordo com uma perspectiva tradicional e instrumental do currículo, a escola é observada apenas como um mero espaço educativo neutro, ignorando qualquer concepção que a veja como um espaço cultural ou de embate entre grupos sociais e econômicos antagônicos. Ao ignorar as mediações de classe e de poder, as teorias tradicionais do currículo tratam a cultura como uma categoria neutra da ciência social ou como critério de padrão de excelência. Está oculto nesse tipo de concepção o fato de a cultura encontrar-se mediada pelo antagonismo de classe, que pressupõe desiguais oportunidades de acesso ao poder e ao conhecimento, bem como uma desigual capacidade de produzir, distribuir e legitimar seus bens culturais no contexto da sociedade.

O grande paradoxo que podemos observar no sistema escolar é que, na maior parte das vezes, o conhecimento e a reflexão a respeito dos modos de vida e de pensar dos atores sociais principais da escola são justamente negados aos mais interessados, ou 
seja, à criança, ao jovem e até mesmo ao professor. Santomé (1995) afirma que dificilmente se encontra no currículo o que denominamos culturas juvenis. Tais culturas seriam as formas de vida, de agir e de pensar, enfim, os usos e costumes, que fazem parte da vida cotidiana dos alunos fora das escolas e que traduzem seus interesses, preocupações e expectativas. O estudo dessas manifestações nos permitiria descobrir o que é realmente relevante em suas vidas. "O adultocentrismo de nossa cultura nos leva a uma ignorância realmente grande acerca do mundo idiossincrático da infância e da juventude" (Santomé, 1995, p. 163). A preocupação do Projeto Culturas Juvenis era justamente, em outras palavras, romper com essa visão adultocêntrica da escola e oferecer aos jovens a oportunidade de manifestarem suas culturas e sua visão de mundo e auxiliar o corpo docente a se beneficiar de uma aproximação intelectual e afetiva do amplo espectro dessas manifestações culturais, mas nos deparamos, em diversos momentos, com entraves e a má vontade da diretoria e dos próprios professores, demonstrando como esta visão está tão cristalizada na cultura escolar.

Segundo Santomé (1995), ao se analisar atentamente os conteúdos desenvolvidos nas instituições escolares, torna-se explícita também a presença das culturas que denominamos hegemônicas e o silenciamento, ou mesmo a deformação e estereotipia das culturas ou vozes dos grupos sociais minoritários. De acordo com o pesquisador, a cultura de cada povo é capaz de traduzir seus construtos conceituais, seus sistemas simbólicos, seus valores, crenças, pautas de comportamentos e outros. É por meio dela que os indivíduos podem estabelecer a sua inclusão em grupos sociais e assim manter uma teia de solidariedade que assegure a continuidade dos grupos. A grande questão é que o sistema educacional ocupa um importante papel nesse sentido. Afinal, é em decorrência das práticas educacionais que o alunado pode construir o sentimento de pertença em relação a um grupo social, tornando-se ciente de suas diversas peculiaridades, que reafirmam os laços de união como grupos de iguais, ao mesmo tempo em que se dão conta de que estas mesmas peculiaridades também os diferenciam de outros indivíduos e comunidades. Por meio dessa diferenciação, adquirem consciência de que existem como indivíduos que compartilham de uma determinada visão de mundo, formando um grupo social, e que existem outros grupos com formas de pensamento e existência diferentes.

A compreensão dessas diferenças não se relaciona, de modo algum, com a crença equivocada de que grupos humanos ou "raças" são superiores ou inferiores a outros. Devemos levar em conta que as ideologias raciais, muitas vezes encobertas por 
um verniz "científico", porém falso, são utilizadas, na realidade, com o intuito de manter determinadas situações de privilégio de um grupo social sobre outro e são o resultado de um contexto histórico, econômico, político, social e cultural da sociedade, no qual foram produzidos (cf. Santomé, 1995).

Ocorre que, nas instituições escolares, os agentes educacionais - sejam eles diretores, coordenadores pedagógicos ou professores - visualizam a si mesmos como indivíduos objetivos e neutros, incapazes, portanto, de produzir e reproduzir comportamentos etnocêntricos. No entanto, uma simples leitura dos materiais curriculares ou mesmo análises etnográficas no interior das salas de aula denunciam condutas que invalidam qualquer argumento de neutralidade que possa ser oferecido pelo sistema educacional. Demonstrações de racismo ou discriminação despontam de todas as formas, sejam conscientes ou não, como em comentários e piadas aparentemente "inofensivas" em relação a indígenas e afro-brasileiros, vindas de integrantes do corpo docente, e tão presentes no cotidiano escolar.

Esse silenciamento e mesmo a predominância de visões estereotipadas acabam por conduzir o sistema educacional a adotar uma mentalidade etnocêntrica, que tende a explicar tudo com base em dicotomias excludentes tais como entre bom e mau, civilizado e selvagem, avançado e atrasado, entre outros. O etnocentrismo é uma ideologia que afirma a diferença de uma sociedade em relação a outro grupo, em especial quando esta sociedade atribui somente aos seus membros os conceitos de "humano" e "civilizado", passando a considerar os outros grupos como "não-humanos" ou "selvagens". O problema do etnocentrismo se agrava quando ele se transforma em um instrumento para legitimar o racismo e a discriminação contra povos minoritários, justificando assim o extermínio, a exploração e a exclusão desses do restante da sociedade. Reforça-se, desse modo, toda uma série de estereótipos e preconceitos acerca de grupos e povos marginalizados, que não dispõem de poder ou representatividade, chegando a atribuir a estes mesmos grupos a responsabilidade das situações em que se encontram e que, na realidade, lhes foram impostas pelos grupos dominantes (cf. Santomé, 1995).

Um verdadeiro silenciamento das - e a respeito das - das etnias minoritárias é uma realidade que temos observado em nossas atividades de pesquisa no interior da EMEF Alcântara. Como exemplo disso, embora essa escola atenda diversos alunos da etnia Pankararu, foram poucas as iniciativas no sentido de promover um esforço conjunto da comunidade escolar, em especial, dos alunos não-indígenas, para o 
conhecimento das particularidades da cultura indígena Pankararu. O questionário realizado trouxe outros dados que confirmam esse quadro. Podemos ver estas representações nas seguintes falas de alunos não-indígenas:

"Eles gostam muito da natureza... mas moram aqui no Real Parque";

"Eles gostam muito da natureza e alguns vivem nela";

"Eu sei que eles são uma tribo de índios e que eles têm uma aldeia no Pernambuco e que é muito bonita";

"O índio tem uma dança muito estranha“;

"Aprendi do modo canibal dos índios";

"Apontar o dedo para os índios causa enfermidade "67.

Observamos, nessas falas, a figura do indígena sendo associada à natureza, habitando em uma coletividade denominada tribo em uma determinada aldeia, provavelmente no interior de uma selva e que possui uma dança "estranha". Chamam a atenção os dois últimos depoimentos que apresentam uma conotação negativa, associando a questão do canibalismo ao indígena, uma imagem apresentada há aproximadamente 500 anos e que persiste no imaginário das pessoas. Além disso, a atribuição da causa de enfermidade ao indígena traz à tona uma visão preconceituosa na qual o nativo está associado a doenças e também a certo temor de um "mundo oculto" representado pelos indígenas, no imaginário da população não-indígena. Essas visões vêm provavelmente da representação do senso comum a respeito dos indígenas, muito difundida por uma cultura escolar distanciada dos debates a respeito da diversidade cultural. Notamos o predomínio de uma visão exótica e naturalizada do indígena como "primitivo" na escola por parte dos alunos, que é aquela do indivíduo morador da selva e amante da natureza, sem se darem conta de que os indígenas Pankararu partilham um cenário comum a todos que vivem no interior do Estado de Pernambuco - ou seja, o semi-árido nordestino, habitando em casas de alvenaria e praticando uma agricultura de subsistência, sendo que muitos dos Pankararu moram também em barracos de favelas em São Paulo, ou seja, nas mesmas condições de vida da própria comunidade no Real Parque.

\footnotetext{
${ }^{67}$ Para realizar uma discussão paralela, uma matéria do dia 14 de fevereiro de 1994 do jornal $O$ Estado de São Paulo relata os argumentos de uma moradora não-indígena da cidade de Manaus que defende a retirada dos índios do local onde mora porque "eles são imundos e agressivos". Segundo o artigo do jornal, esta moradora proíbe a aproximação de seus filhos com os indígenas alegando que eles possuem doenças contagiosas.
} 
Segundo Bonin (2007), o indígena é apresentado geralmente como:

uma figura genérica, estereotipada, exótica, representada pela alegria, ingenuidade, liberdade, habitando em um lugar fixo, amalgamado à natureza. Um dos efeitos dessas representações é o estranhamento que nos causa o encontro com indígenas em contextos urbanos, participando de atividades comerciais, pedindo esmolas, ou em noticiários que deixam ver, de relance e de modo fugaz, a situação de miséria e violência a que estão submetidos muitos povos indígenas na atualidade brasileira (Bonin, 2007, p. 9).

É preciso observar que entendemos estereótipo como sendo marcas e qualificações - que vão desde padrões estéticos até comportamentos - que são constantemente atribuídas aos indivíduos, tornando-se fixas e inalteráveis de acordo com o tempo, assumindo, muitas vezes, uma feição do senso comum. Os estereótipos acabam por se basear e a se vincular aos preconceitos. Como podemos observar, o estereótipo, bastante arraigado na concepção do senso comum de um indígena "primitivo", acaba se voltando justamente contra os próprios indígenas que habitam nas grandes cidades e que freqüentam uma escola que não está inserida em comunidades tradicionais, contribuindo para um quadro bastante propício para o preconceito e a discriminação, uma vez que a figura do indígena assume uma conotação negativa perante alunos e professores. 


\section{A cultura escolar e os "currículos turísticos"}

De acordo com Candau (2000), o atual sistema público de ensino, estabelecido sobre os pilares da modernidade e sobre as proposições da universalização do ensino no qual todos têm direito à escola básica e a conhecimentos sistematizados como "universais" - acabou por criar uma cultura escolar marcada pela padronização, pelo ritualismo, pelo pouco dinamismo e preocupada em dar ênfase a processos de mera transferência de conhecimentos, que estão referidos, em geral, à cultura de "determinados atores sociais, brancos, de classe média, de extrato burguês e configurados pela cultura ocidental, considerada como universal" (Candau, 2000, p. 53). Essa cultura escolar cristalizada possui uma grande dificuldade de incorporar as diversas linguagens e expressões culturais presentes, de modo geral, nas novas gerações e nos diferentes grupos culturais. "Mudam as culturas sociais de referência, mas a cultura da escola parece gozar de uma capacidade de se autoconstruir independentemente e sem interagir com estes universos" (Candau, 2000, p. 54).

No entanto, de acordo com Giroux:

Os/as educadores/as não poderão ignorar, no próximo século, as difíceis questões do multiculturalismo, da raça, da identidade, do poder, do conhecimento, da ética e do trabalho que, na verdade, as escolas já estão tendo de enfrentar. Essas questões exercem um papel importante na definição do significado e do propósito da escolarização, do que significa ensinar e da forma como os/as estudantes devem ser ensinados/as para viver em um mundo que será amplamente mais globalizado, high tech e racialmente diverso que em qualquer outra época da história (Giroux, 1995, p. 88 Apud Candau, 2000, p. 54).

Um perigo que se corre ao se tratar a temática indígena em uma cultura escolar engessada, como explicitada acima, é cair em propostas de trabalho do que Santomé (1999) qualifica como currículos "turísticos", nos quais, esporadicamente e em unidades didáticas isoladas, é estudada a diversidade cultural. Ou como se fossem "temas transversais", ou seja, que não devem ser obrigatoriamente incluídas e tratadas no currículo oficial. De acordo com esse enfoque, as culturas silenciadas são contempladas quando muito com distanciamento, como se fossem estranhas, exóticas ou até mesmo problemáticas. 
Segundo Santomé (1995), os tipos de estratégias dos currículos "turísticos" podem ser descritos da seguinte forma:

- trivialização - estudando os grupos sociais minoritários com superficialidade e banalidade, ou seja, segundo o estilo turístico, priorizando somente as formas de vestir, o "folclore", os rituais festivos, a decoração das habitações entre outros. E também destacando, dentre as unidades didáticas, somente uma pequena parcela do conteúdo para se tratar da questão da diversidade cultural, como se fosse um souvenir;

- desconexão entre as situações de diversidade e a vida cotidiana das salas de aula - uma das formas mais comuns de se tratar a diversidade cultural. É quando se reserva apenas um determinado dia e em uma única disciplina para se tratar dessa problemática social, enquanto que nos outros dias do ano letivo, ela é silenciada ou mesmo atacada;

- estereotipia - fazer referência a indivíduos e grupos sociais por meio de imagens estereotipadas das pessoas e das situações a que pertencem esses grupos;

- tergiversação - quando se utiliza a estratégia de deformação e ocultação da história e das origens dos grupos sociais que são vitimados pela marginalização. Esse seria o caso mais perverso de abordagem do currículo, pelo fato de se buscar elaborar uma história que naturalize as situações de opressão, justificando as idéias de inferioridade de grupos sociais por via de argumentos racistas. Nessas formas de tergiversação, acaba-se por ignorar as verdadeiras relações e estruturas de poder que são as causadoras das situações de marginalidade.

Estas estratégicas acabam por silenciar a existência de outras culturas e reproduzem a marginalização. Para ilustrar um quadro em que estes expedientes são utilizados no ambiente escolar, nas comemorações do Dia do Índio ${ }^{68}$ do ano de 2007 , uma das professoras da EMEF Alcântara fez uma atividade de pesquisa com os alunos a

\footnotetext{
${ }^{68}$ Bonin (2007) aborda a questão de que o "Dia do Índio", dia 19 de abril, foi escolhido para homenagear o herói indígena Cuauhtemoc e foi oficializado no I Congresso Indigenista Interamericano, realizado no México, em 1940, passando a ser confirmado por todos os países latino-americanos. Também nos lembra que foi a partir da década de 1940 que, no Brasil, a literatura e a produção didática passaram a assumir um caráter ufanista e nacionalista, o que contribuiu para a produção de discursos comemorativos que "subjugam as culturas indígenas e legitimam essa subordinação como condição de unidade e desenvolvimento de um projeto de nação. Assumindo um sentido comemorativo, a abordagem ganha contornos específicos, colaborando para marcar o que deve ser lembrado e o que, em decorrência, deve ser esquecido" (Bonin, 2007, p. 6).
} 
respeito das etnias indígenas. Os trabalhos foram apresentados no mural do pátio da escola e neles pudemos observar descrições de várias etnias indígenas, como os Pataxó e Kaingang, mas não havia nenhum trabalho que tratasse dos indígenas Pankararu, que residem justamente na comunidade situada no entorno da escola.
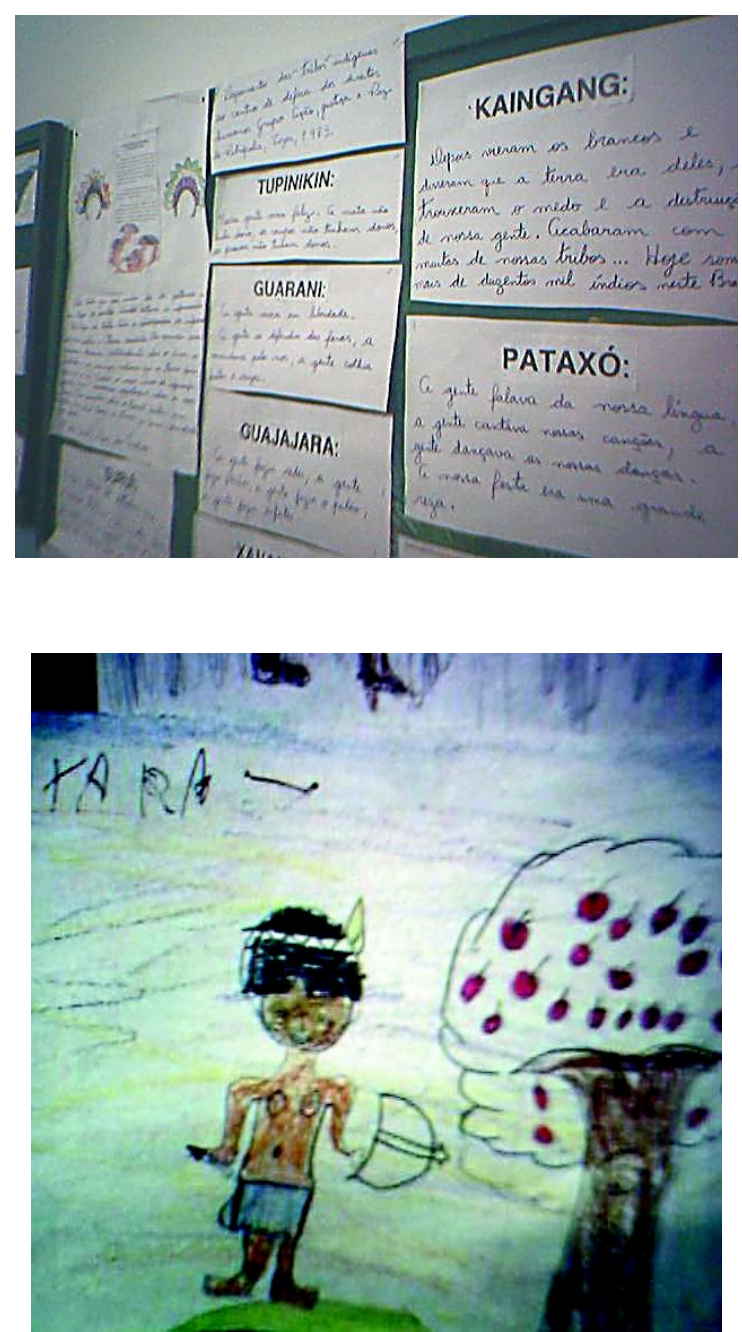

O motivo dessa ausência provocou espanto nos pesquisadores e em alguns professores. Em uma das JEI's, a equipe de pesquisa comentou a respeito da ausência de trabalhos referentes aos Pankararu nos trabalhos dos alunos. A professora que realizou a atividade com os alunos, presente na JEI, mostrou-se bastante incomodada com os comentários feitos pelo grupo de pesquisa e retrucou que foram os próprios alunos que não desejaram realizar nenhum trabalho com os Pankararu. Embora não pudéssemos avaliar com precisão porque isso teria ocorrido, podemos supor que, na visão dos alunos, é considerado indígena somente aquele que vive em uma realidade temporária e fisicamente distante, habitando em aldeias nas matas, e que não vive em 
um contexto social próximo ao do próprio aluno não-indígena, em seu próprio bairro, na cidade de São Paulo. Haveria também, no caso dos próprios alunos Pankararu, o receio de se colocarem como indígenas nas referidas atividades e poderem ser alvos de chacotas e discriminação. Em todo caso, pareceu-nos ser um indicativo claro do silenciamento ao qual estão submetidos os indígenas Pankararu na escola, gerando dificuldades na auto-identificação dos indígenas no estabelecimento escolar.

De acordo com Santomé (1999), é necessário compreender que uma política educacional que tenha a pretensão de recuperar as culturas que foram silenciadas não deve se restringir a produzir unidades didáticas isoladas ou série de lições direcionadas a este fim. Um currículo que pretenda atuar contra a marginalização e a negação dessas culturas deve levar em conta as culturas silenciadas todos os dias do ano letivo, em todas as tarefas acadêmicas e com todos os recursos didáticos. Se de fato o objetivo do trabalho educativo deveria ser o de formar pessoas críticas, ativas e solidárias, que contribuam para constituir e reconstruir uma realidade, é necessário refletir com profundidade a respeito das estratégias de ensino, aprendizagem e avaliação.

\section{Os livros didáticos}

No Brasil, a escolha dos livros didáticos a serem utilizados nas escolas é centralizada pelo Ministério de Educação do Governo Federal, por meio dos chamados Programas Nacionais do Livro Didático (PNLD - Programa Nacional do Livro Didático; PNLEM - Programa Nacional do Livro Didático para o Ensino Médio; PNLA - Programa Nacional do Livro Didático para a Alfabetização de Jovens e Adultos). Segundo o texto do folder de apresentação do PNLD, o objetivo desses programas é disponibilizar aos alunos das redes públicas de ensino federal, estadual, municipal e de outras instâncias obras didáticas de qualidade. Estes livros ou coleções didáticas seriam selecionados por uma comissão avaliadora formada por especialistas escolhidos pela Secretaria de Educação Básica (SEB), seguindo critérios préestabelecidos em editais elaborados pela Fundação Nacional do Desenvolvimento da Educação (FNDE). As referidas obras seriam adquiridas de forma centralizada pelas instâncias dos governos e distribuídos gratuitamente aos alunos de todas as séries do ensino fundamental e médio da rede pública de ensino e aos matriculados em classes do 
programa Brasil Alfabetizado ${ }^{69}$. Também há uma referência de que os diretores e professores auxiliariam na escolha das coleções de livros mais adequadas à realidade do aluno e ao projeto pedagógico da escola, mediante processo de discussão e consenso. Ainda de acordo com o texto do PNLD, o livro, confeccionado com uma estrutura física resistente, deve ser utilizado/reutilizado por três anos consecutivos, com o intuito de beneficiar mais de um estudante nos anos posteriores.

De acordo com o Guia de Livros Didáticos - PNLD 2008 - História, no texto que discorre sobre os critérios e métodos de avaliação, está assim registrado:

A área de História, diferentemente de outras, não contempla um documento que determine itens de conteúdos históricos prévios para a realização dos programas escolares. Apesar dos Parâmetros Curriculares Nacionais (PCN) de História, tanto os do Ensino Fundamental como os do Médio, orientarem sobre a escolha e os procedimentos ao se trabalhar com os temas nesta disciplina, não há indicação de conteúdos mínimos obrigatórios.

Decorrente disso, há muitas opções tanto para a seleção dos conhecimentos históricos como para a montagem da estrutura de uma obra didática na área. Assim, considerou-se, para a constituição de grupos nas coleções avaliadas neste PNLD, a forma como os autores dispuseram os assuntos, distribuindo-os ao longo dos quatro volumes, e o que estabeleceram como elemento organizador da obra (Guia dos Livros Didáticos, PNLD/2008, p. 11).

Esse pequeno registro deixa transparecer que, apesar de todas as discussões que, bem ou mal, foram realizadas em relação à temática da Pluralidade Cultural nos PCN, elas podem muito bem deixar de serem utilizadas como critério para a avaliação dos livros didáticos de história, optando-se assim por uma maior "liberdade" para a seleção dos conhecimentos históricos. Desse modo, podemos notar um desencontro entre as diversas propostas estabelecidas a respeito do reconhecimento de uma diversidade sócio-cultural no Brasil.

O único critério de seleção dos livros que atenta para uma maior atenção à pluralidade sócio-cultural, que é o de Construção da cidadania, encontra-se descrito assim:

\footnotetext{
${ }^{69}$ Dados oficiais afirmam que teriam sido adquiridos um número aproximado de 120 milhões de livros, com orçamento de quase R \$ 1 bilhão, beneficiando cerca de 40 milhões de alunos e 160 mil escolas da educação básica.
} 
Este item considera se a coleção aborda a diversidade das experiências humanas com respeito e interesse, se estimula o convívio social, o respeito, a tolerância e a liberdade; se abrange a formação da cidadania no conjunto do texto didático, e não apenas nas atividades ou em um capítulo, relacionando-a ao conteúdo histórico; se aborda as temáticas das relações étnico-sociais e de gênero, considerando o combate ao preconceito, à discriminação racial e sexual e à violência contra a mulher, com vistas à construção de uma sociedade anti-racista, justa e igualitária; enfim, se discute a historicidade das experiências sociais, ao trabalhar conceitos, habilidades e atitudes na construção da cidadania, contribuindo para o desenvolvimento da ética necessária ao convívio social (Guia dos Livros Didáticos, PNLD/2008, p. 11).

Pode-se observar, no texto que descreve o critério, que há menções a respeito da diversidade, do respeito, da tolerância, além das relações étnico-sociais, do combate ao preconceito e à discriminação racial, necessárias à formação da cidadania, mas não há uma menção específica a respeito do tratamento que o livro didático deva oferecer à questão indígena ou afro-brasileira. São formulações genéricas, que não abordam justamente as vítimas da intolerância, do preconceito e da discriminação racial. O resultado disso é que o trabalho com a temática indígena nos livros didáticos torna-se severamente prejudicado.

Como exemplo, concentraremo-nos em alguns livros didáticos adotados pela EMEF Alcântara no tocante à temática indígena. Em uma coleção didática denominada Caracol (Castro et alli, 2004), do Ensino Fundamental, adotada pelo PNLD 200770, no livro dedicado à $3^{\mathrm{a}}$ série, que continha 144 páginas, apenas cinco delas tratavam da questão indígena, contidas na seção Outros tempos, outras histórias. O próprio nome da seção é bastante sugestivo, pois aparenta posicionar os indígenas em Outros tempos, dando a entender que seria um tempo passado ou mítico. Embora haja uma preocupação constante no texto em registrar a diversidade dos povos indígenas existentes no Brasil, há uma descrição bastante genérica dos modos de vida e dos costumes indígenas (concentrando-se na etnia Tupinambá, pois o texto didático se baseia no relato de Hans Staden presente em sua obra Duas viagens ao Brasil [1974], em que narra seu contato com essa etnia no ano de 1554) e um tom que busca ser "favorável" aos povos nativos, colocando-os como vítimas da colonização realizada pelos portugueses. Além disso, um

\footnotetext{
${ }^{70}$ Uma das coordenadoras pedagógicas da EMEF Alcântara comentou que, em sua opinião, embora a coleção apresentasse diversos problemas em seu conteúdo, ela era adotada com freqüência e bastante elogiada pelos professores.
} 
desenho de Hans Staden de uma aldeia Tupinambá, retratando indígenas nus, mas com feições européias, ocupa mais que a metade de uma página. Na página posterior, há uma ilustração que mostra indígenas com lanças nas mãos, em posições de ameaça a um personagem de cabelos louros (indicando ser este Hans Staden). O espaço exíguo dado à temática indígena no livro, além de uma abordagem que privilegia uma visão "passadista" do indígena, acaba por reforçar a visão de um índio "primitivo", como abordado anteriormente.

Na mesma coleção, no livro direcionado à $4^{\mathrm{a}}$ série, a abordagem da questão indígena se inicia no capítulo $O$ descobrimento do Brasil e o encontro de dois mundos. O texto desse capítulo apresenta para os alunos a visão dos portugueses a respeito dos indígenas, como se pode observar a propósito do evento "Descobrimento". No texto, está assim registrado: "A história do descobrimento começa com a chegada das caravelas portuguesas ao Brasil, em 22 de abril de 1500” (Castro et alli, 2004, p. 39, grifo nosso). No entanto, o próprio termo utilizado, "Descobrimento", é considerado antiquado e etnocêntrico há certo tempo por muitos especialistas pelo fato de estabelecer a História do Brasil a partir da chegada dos portugueses ao país e por desconsiderar toda a população existente antes dessa data, registrando os indígenas como uma "sociedade sem história". Isso, por si só, já demonstra o silenciamento ao qual os povos nativos foram submetidos nos livros didáticos ${ }^{71}$. Desse modo, a abordagem da temática indígena é tratada no contexto da chegada dos portugueses ao Brasil e ainda persiste uma imagem de um indígena "primitivo". A crítica que se faz, nesse sentido, não é a de que não se deveria abordar os eventos do contato entre portugueses e povos indígenas no Brasil, mas sim pelo fato de sempre associar a imagem do indígena a um passado distante, apresentando uma visão estereotipada do mesmo.

Em sua dissertação de mestrado, Gobbi (2006) analisou os livros recomendados pelo PNLD nos anos de 1999 a 2005 no tocante à temática indígena. Embora tenha notado alguns avanços em relação a uma melhor incorporação de estudos antropológicos atuais, a pesquisadora constatou a "reprodução de estereótipos, a utilização de pressupostos evolucionistas, diversidade de concepções errôneas, a presença de noções etnocêntricas, a menção dos povos indígenas pertencentes ao passado, a desconsideração dos saberes indígenas" (Gobbi, 2006, p. 103), entre outros

\footnotetext{
${ }_{71}$ Neste mesmo livro, há também uma profusão de fotos e ilustrações que associam os negros à escravidão, ou seja, ainda uma imagem do negro ou afro-brasileiro vinculado ao passado, descontextualizado do presente.
} 
aspectos, fatores que se devem considerar bastante graves, pelo fato de os referidos livros didáticos serem destinados a crianças e adolescentes que estão formando suas concepções de mundo e sua imagem do outro.

Para Gobbi (2006), a impressão que se tem é a de que os autores dos livros didáticos procuram se adequar aos critérios usualmente adotados pelos livros didáticos de não expressarem qualquer "preconceito de origem, etnia, gênero, religião, idade ou outras formas de discriminação", além de deverem estar atentos a "qualquer possibilidade de o texto ou as ilustrações sugerirem ou explicitarem preconceitos" (Guia de Livros Didáticos, PNLD/2005). Nesse sentido, adaptaram os conteúdos didáticos para evitar quaisquer problemas com os critérios expostos, mas não se preocuparam em dar coerência ao que neles estavam sendo expostos. Os autores buscaram incorporar uma idéia antropológica de cultura e assumiram idéias anti-racistas, mas não foram capazes de articular um texto que fosse capaz de se contrapor criticamente ao preconceito e às formas de discriminação ${ }^{72}$, como exposto nos critérios do PNLD. Enfim, "os livros didáticos, em sua maioria, continuam reproduzindo uma idéia evolucionista de História" (Gobbi, 2006, p. 104).

Para Santomé (1999), nos livros didáticos, o racismo se verifica por meio do silenciamento produzido em relação às características, aos acontecimentos históricos, sócio-econômicos e culturais representativos das comunidades e etnias minoritárias. Ele se dá também por meio de descrições estereotipadas desses mesmos povos. Assim, devemos levar em conta também o contexto histórico da formação dos professores. $\mathrm{O}$ que se exigia anteriormente dos profissionais de ensino era apenas formular objetivos e metodologias, não cabendo a ele selecionar os conteúdos a serem ensinados. Tal seleção foi relegada a terceiros, em muitos casos, às editoras de livros didáticos, ou mesmo decididas pelas secretarias de ensino. Desse modo, os conteúdos apresentados nos livros didáticos passaram a ser considerados como os únicos possíveis e pensáveis, mesmo que os alunos os vissem como fórmulas vazias, sem que fosse necessária a compreensão de seu sentido. Uma vez retirada a decisão dos professores sobre os conteúdos, pensar em conteúdos diferentes dos tradicionais torna-se um processo complicado. Na EMEF Alcântara, alguns professores comentaram que alguns dos livros selecionados por eles nos processos de avaliação do PNLD não foram contemplados, sendo então escolhidos livros para a escola que não foram considerados adequados pelos docentes. Em razão

\footnotetext{
${ }^{72}$ Por experiência do próprio pesquisador, que trabalhou na área de editoração, muitos autores didáticos negociam os conteúdos elaborados por eles com as editoras, cabendo às equipes editoriais (editores e revisores) a adequação dos livros aos critérios do PNLD.
} 
disso, muitos simplesmente abandonaram os livros didáticos propostos e elaboraram suas aulas de acordo com o que consideram pertinentes ao alunado ao qual atendem, demonstrando-se, assim, um contra-senso educativo, pois todo o esforço desprendido até o momento para se incluir uma discussão a respeito da diversidade cultural na escola se perde, em termos práticos, no processo de transposição da temática para a sala de aula. "Não constitui nenhuma surpresa, pois, que nessa altura da história já sejam muitas as vozes ausentes e/ou deformadas na maioria dos currículos" (Santomé, 1995, p. 161).

\section{Segundo Santomé:}

o discurso educacional tem que facilitar que os alunos de etnias oprimidas, assim como as dos grupos dominantes possam compreender as inter-relações entre os preconceitos, falsas expectativas e condições infra-humanas de vida das populações marginalizadas com as estruturas políticas, econômicas e culturais dessa mesma sociedade (Santomé, 1995, p. 171).

Uma pedagogia que se afirme antimarginalizadora deve considerar as dimensões éticas dos conhecimentos e das relações sociais. É necessário que as instituições escolares possibilitem a análise de como e por que as discriminações surgem e ocorrem; e que as palavras que fazem parte do vocabulário da evolução democrática da sociedade (como poder, justiça, direito e outros) não se tornem uma mera retórica de um vocabulário academicista e que estejam descontextualizadas da vida cotidiana da comunidade (cf. Santomé, 1995). 


\section{Um estudo mais detido: intervenções na classe " $7^{\mathrm{a}} B$ "}

De todas as classes observadas, a que mais nos chamou a atenção em relação ao nosso objeto de pesquisa foi a sala chamada " 7 a B", pois nela identificamos um número maior de alunos da etnia Pankararu do que em outras salas, o que nos poderia fornecer uma oportunidade de aproximação do universo dos alunos indígenas. Desse modo, essa classe se configurou como um espaço privilegiado para a investigação de que maneira se daria a interação dos alunos Pankararu com os outros alunos e com a escola e verificar se estaria havendo, de fato, uma negação da identidade indígena ou um processo de afirmação étnica.

A análise das respostas aos questionários (cf. Amaral, 2007) nos mostrou a necessidade de criar grupos específicos para pesquisar determinadas manifestações culturais presentes entre os alunos. Assim, como segunda etapa de nossa pesquisa e como parte da segunda fase do Projeto Culturas Juvenis, criamos, em julho de 2007, outro subgrupo para investigar especificamente os alunos Pankararu a partir de intervenções realizadas em sala de aula. Participaram deste subgrupo: o próprio pesquisador assim como os professores L. (Geografia), C. (Matemática) e P. (Informática). Estes professores possuíam anos de experiência pedagógica, além de terem trabalhado e convivido por muito tempo com a realidade e os desafios da EMEF Alcântara. Foram realizadas cinco intervenções no período de 20 de agosto a 16 de novembro de 2007, com intervalos de aproximadamente duas semanas entre cada encontro.

\section{A visão dos alunos sobre os Pankararu}

No que diz respeito à cultura da comunidade indígena Pankararu, alguns alunos disseram desconhecer por completo sua cultura, mesmo tendo colegas na classe que afirmaram ter ascendência indígena Pankararu. Outros demonstraram ter uma simpatia por eles, dizendo estarem abertos a conhecê-los melhor, ou que tinham amigos dentre eles. Alguns se lembraram que vieram de Pernambuco, foram os pioneiros do bairro e que participaram da construção do estádio do Morumbi. Vejamos algumas das representações sobre essa comunidade: 
"Vieram de Pernambuco para buscar vida melhor e conseguiram, apesar das dificuldades."

"Sei que eles foram os primeiros a chegarem ao bairro."

"Eu conheço porque convivo com eles. Eu sei que eles foram um dos primeiros a chegar aqui no Real Parque."

"Sei que eles são índios, que eles ajudaram muito no começo de nosso bairro Real Parque e que hoje moram aqui."

"Tenho uma amiga que é descendente deles. Sei que eles vieram de Pernambuco e ajudaram a construir o Estádio do Morumbi."

"Só sei que eles vieram para São Paulo, na favela, e construíram muitas casas e, quando chegaram, era tudo mato, e lá onde eles viviam era muito difícil. Por isso vieram para cá."

É interessante observarmos, em algumas falas dos colegas de classe dos alunos Pankararu, a representação que possuem a respeito da comunidade indígena. Alguns elementos culturais dos Pankararu sobressaem na visão dos alunos. Destacamos alguns desses elementos:

"Conheço de vista, mas sei que eles têm um ritual de dança."

"Uma coisa que eu admiro é a dança deles."

"Eu sei que os Pankararu são uma tribo de índios que cantam e dançam na língua deles e tem umas comidas exóticas."

"Eu já vi eles dançando e cantando aqui na nossa comunidade e a fala deles é diferente quando estão cantando."

"Eu sei que eles eram de Pernambuco e vieram para cá. A língua deles é diferente."

"Eu sei que eles falam diferente das nossas línguas."

"Eu sei deles que quando estão vestidos de Praiás, ninguém pode falar qual é a pessoa que está vestindo, porque dizem que ela fica doente."

Podemos observar nestas falas que a dança dos Pankararu é um elemento cultural que mais se destaca para os alunos, além da "língua diferente" mencionada. A dança aludida é o Toré, ritual já descrito anteriormente, que se tornou um elemento cultural mais identificável, constituinte e unificador dos Pankararu, transformando-se em um emblema tanto para os indivíduos que pertencem ao grupo indígena como para os que não pertencem, firmando-se assim como símbolo de "indianidade". 
Cabe lembrar que os Pankararu, por terem perdido sua língua materna nos tempos coloniais, comunicam-se atualmente em português. Da língua materna, restaram algumas palavras, que são cantadas em suas manifestações culturais. É pela observação do Toré em eventos públicos que os colegas dos alunos Pankararu fazem referência à "língua diferente", o que demonstra que esse elemento também se torna definidor da "indianidade" dos Pankararu. Por fim, novamente temos a referência do Praiá e a ameaça de punição do indivíduo que utiliza a vestimenta cerimonial caso este revele a sua identidade, o que também chama a atenção das pessoas que não são Pankararu.

\section{Identidade}

$\mathrm{Na}$ análise das respostas dos questionários, um dado nos chamou a atenção. Entre os alunos que afirmaram descender dos Pankararu, foram poucos os que reconheceram efetivamente sua identidade étnica. Os próprios alunos descendentes aparentaram conhecer pouco ou até mesmo desconhecer sua cultura e seus costumes em suas falas, tratando o tema como se fosse alheio às suas vidas ou mesmo parecendo tomar distância em relação às suas origens. É o que se pode observar nos seguintes relatos:

"Sim, eu sou descendente deles. Os Pankararu sempre fazem festa no Dia do Índio. Sempre há danças na quadra do projeto Casulo. Eles falam os mesmos termos que nós, as comidas deles não são diferentes das nossas";

"Eu não sei nada sobre os índios, eu só sei que minha mãe é índia".

Podemos observar, nestas respostas, a oposição que estabelece entre "eu" e “eles", "nós" e "eles", enfim, entre a $1^{\text {a }}$ pessoa do singular ou plural e a categoria “índios”. Essas respostas, logicamente, necessitam ser contextualizadas, mas revelam, em todo caso, a dificuldade de muitos dos descendentes Pankararu de se identificarem como indígenas. Podemos observar uma relação ambivalente dos alunos com a sua identidade étnica, seja por não possuírem um sentimento de pertencimento à comunidade indígena, seja por não desejarem se declarar como indígenas na escola como expressão de uma possível autodefesa, em razão do receio da discriminação exercida sobre os indígenas, tanto por parte dos alunos como do próprio corpo docente. 
Segundo Moura (2007), a discriminação dos povos indígenas se consolidou no Brasil de modo institucional a partir da afirmação da desigualdade racial, uma vez que racismo passou a ser amparado pela própria legislação que regia a questão indígena, sendo esta impelida por interesses econômicos, justificava a dominação aos grupos considerados "inferiores". A partir disso, foram criadas as condições para o aparecimento de uma outra espécie de racismo, este de cunho cultural, que passou a ser tragicamente assimilado pelo próprio indivíduo discriminado. Uma vez submetidos ao sistema dominante, os indígenas começaram a se ver por meio dos "olhos dos brancos" ou, melhor dizendo, filtrados pela ideologia dos brancos. Eles passaram a se ver como seres inferiores, intrusos e indolentes, cujo único destino é trabalhar para o branco (cf. Cardoso de Oliveira, 1976).

Para compreender esse fenômeno, buscamos referências no trabalho antropológico de Roberto Cardoso de Oliveira, que, ao pesquisar a respeito das relações interétnicas entre a sociedade nacional majoritária e os grupos indígenas, produziu obras como O processo de assimilação dos Terêna (1960), O índio e o mundo dos brancos (1964) e Identidade, etnia e estrutura social (1976). É na primeira obra que o antropólogo, ao investigar o contato dos indígenas Tükúna com a sociedade branca, estudou o fenômeno social que denomina como "caboclismo", no qual averigua o surgimento de uma nova categoria social: o caboclo. Para Cardoso de Oliveira, o caboclo:

(...) é o índio integrado (a seu modo) na periferia da sociedade nacional, oposto ao 'índio selvagem', nu ou semivestido, hostil ou arredio (...). Em certo sentido, o caboclo pode ser visto ainda como o resultado da interiorização do mundo branco pelos Tükúna, dividida que está sua consciência em duas: uma, voltada para os ancestrais, outra, para os poderosos homens que o circundam. O caboclo é, assim, o Tükúna vendo-se a si mesmo com os olhos do branco (...) Parafraseando Hegel, poder-se-ia dizer que o caboclo é a própria 'consciência infeliz'. Fracionada sua personalidade em duas, ela bem retrata a ambigüidade de sua situação total (...) (Cardoso de Oliveira, 1964, p. 117).

Neste pequeno trecho, o antropólogo procura descrever o processo de acordo com o qual os indígenas passam a se identificar por meio dos "olhos dos brancos". Nesse sentido, para se contrapor às condições sociais excludentes, estes indígenas se 
vêem instados a renunciar à sua identidade étnica, como um modo de fugir do estigma e da discriminação. Embora toda esta conceituação teórica tenha sido elaborada pelo antropólogo nas décadas de 1960 e 1970, ou seja, antes da eclosão do movimento indígena, e também em um contexto bastante específico, pretendemos utilizar as definições teóricas de Cardoso de Oliveira como elementos-chave para compreender com mais propriedade o que temos observado na EMEF Alcântara. Como o próprio Cardoso de Oliveira escreveu, em um de seus artigos mais recentes, Identidade étnica e moral do reconhecimento (2006):

\begin{abstract}
Essa identidade alienada, que cheguei a caracterizar como 'consciência infeliz', seria ela congruente com esses novos tempos que abriga a consciência indígena e a luta política pela cidadania que ela está investida? Claro que não. (...) Todavia, acredito ser importante retomá-la nesses novos tempos marcados por uma nova consciência étnica porque tal identidade configura um modelo não totalmente desaparecido, pois dotado de fôlego suficiente para poder ainda ser observado em plena atividade em certos rincões do país (Cardoso de Oliveira, 2006, p. 42).
\end{abstract}

Podemos observar que, embora a etnicidade indígena esteja passando por um momento de valorização sem precedentes na história nacional, também não deixa de ser verdade também que existam ainda espaços, numerosos por sinal, nos quais predomina um ambiente propício para o preconceito e a discriminação contra o indígena. Podemos citar a escola, principalmente a não-indígena, como um destes espaços onde predominam uma visão etnocêntrica e preconceituosa para com eles.

De acordo com Baines (2001), do ponto de vista legal, o Artigo 3 do Estatuto do Índio (Lei No. 6.001, de 19 de dezembro de 1973) define o índio como "todo indivíduo de origem e ascendência pré-colombiana que se identifica e é identificado como pertencente a um grupo étnico cujas características culturais o distinguem da sociedade nacional". O paradoxo que se estabelece é que do mesmo modo que a indianidade é acionada para obter reconhecimento de direitos específicos, a identidade indígena nas cidades (e nas escolas) é freqüentemente ocultada como parte de uma estratégia para escapar dos preconceitos e estigmas. "A identidade indígena nos centros urbanos configura-se nitidamente como uma identidade social contextual. A mesma pessoa pode se considerar indígena em alguns contextos, e não em outros, ou apelar a outras identidades genéricas geradas historicamente em situações de contato interétnico, como 
caboclo, índio civilizado, descendente de índio, remanescente, índio misturado, etc.“ (Baines, 2001, p. 2). Ou seja, como Cardoso de Oliveira (2006) afirma, em ambientes carregados de preconceito, escamotear uma identidade étnica pode significar um ganho social ou garantia de maior respeitabilidade.

\section{As duas dimensões da identidade}

Para Cardoso de Oliveira (2003), a noção de identidade contém duas dimensões: a pessoal (individual) e a social (ou coletiva). Em trabalhos sobre a noção de identidade realizados por antropólogos e sociólogos, tem se enfatizado a questão de que o pessoal e o social estão interconectados, podendo-se tomá-las como dimensões de um fenômeno que está situado em diferentes níveis de realização - o nível individual, da identidade pessoal que é objeto de investigação de psicólogos, e o nível coletivo, em que a identidade social se edifica e se realiza.

A importância de tomar a identidade como um fenômeno bidimensional permite, por outro lado, incorporar as contribuições dos estudos psicológicos, especialmente relevantes para a descrição dos processos de identificação, mantendo-nos fiéis ao princípio durkheimiano de explicar o social pelo social (sem que isso signifique ignorar o 'fato psíquico' - o que freqüentemente tem ocorrido na melhor tradição da antropologia social) (Cardoso de Oliveira, 2003, p. 119).

Assim, Cardoso de Oliveira incorporou a contribuição dos trabalhos psicológicos aos seus estudos para uma análise da temática da identidade em etnias indígenas presentes no Estado de Mato Grosso, tomando como base os estudos do psicanalista Erik Erikson e da psicóloga Mary E. Goodman, utilizando as formulações teóricas destes dois autores para analisar a posição desfavorável dos indígenas Kinikináu diante dos Têrena e dos indígenas em geral em relação à sociedade nacional. Também recorreremos a essas formulações para compreendermos também a questão identitária indígena na EMEF Alcântara.

Segundo Cardoso de Oliveira (2003), entre as influências desagregadoras que mais atingem os grupos indígenas que estão em contato sistemático com a sociedade nacional estão aquelas que afetam as suas populações infantis. Situações contínuas de 
discriminação despertam nas crianças indígenas uma consciência negativa de si, o que Erikson qualifica como "identidade negativa", que seria:

(...) a soma de todas aquelas identificações e os fragmentos de identidade que o indivíduo tem que reprimir em si mesmo por serem indesejáveis ou irreconciliáveis, ou pela qual indivíduos atípicos e minorias marcadas são forçadas a se sentir 'diferentes'. No caso de crises agravadas, um indivíduo (ou mesmo um grupo) pode perder as esperanças de ter habilidade para conter esses elementos negativos numa identidade positiva (Erikson, 1970, p. 733 Apud Cardoso de Oliveira, 2003, p. 127).

Segundo Erikson (1968), o indivíduo pertencente a uma minoria oprimida e explorada e que seja consciente dos ideais culturais dominantes, acaba fundindo as conotações negativas que lhes são atribuídas por uma maioria dominante com a identidade negativa que é cultivada pelo próprio sujeito. Desse modo, torna-se plausível que a denominada "identidade negativa" se prolongue também nos períodos da adolescência e maturidade, dificilmente se transformando em uma identidade positiva que possa auxiliar um indivíduo ou grupo a enfrentar situações críticas. Ainda que não se possa afirmar categoricamente que esses valores negativos se desenvolvam já na infância, não se pode negar a real possibilidade de que isso efetivamente ocorra nesse período de desenvolvimento (cf. Cardoso de Oliveira, 2003). Como exemplo, o antropólogo cita a pesquisa de Mary E. Goodman (1964), que chega à conclusão de que as crianças podem demonstrar sinais de intolerância racial já a partir dos quatro anos de idade, o que demonstra, segundo Cardoso de Oliveira (2003), em contrapartida, a possibilidade de que elas possam constituir desde cedo uma consciência étnica.

Com base nos pressupostos acima mencionados, Cardoso de Oliveira (2003) relata uma pesquisa realizada em 1957 junto aos indígenas Têrena na qual se pode visualizar a dimensão do "preconceito racial" entre alunos de uma escola ${ }^{73}$ nas proximidades de uma reserva indígena. Nesta pesquisa, solicitou-se aos alunos (de sete a onze anos), com a anuência da professora, pequenas composições sobre os indígenas, seus hábitos e costumes. Seu interesse a respeito da pesquisa se justifica pelo fato de ser uma escola nas proximidades de uma aldeia indígena. A análise dos trabalhos escolares demonstrou que a maior parte deles se referia a um indígena abstrato, portando "arco e

\footnotetext{
${ }^{73}$ Uma escola primária da povoação de Duque Estrada, a oito quilômetros da aldeia de Cachoeirinha, que está localizada no município de Miranda, região oeste do Estado do Mato Grosso do Sul.
} 
flecha" e "adorando o sol e a lua", o mesmo indígena apresentado usualmente nos livros didáticos. Os poucos trabalhos que mencionaram os indígenas Têrena se referiam a eles como "bugres", “decadentes", "misturados", “alcoólatras", entre outros, sempre em comparação com os "verdadeiros indígenas". O antropólogo, no entanto, destaca o fato de três alunos Têrena, presentes na sala de aula, reagirem como se o assunto abordado nos trabalhos não tivesse relação com eles, escrevendo nos trabalhos praticamente elementos do mesmo teor dos outros alunos. Pode-se presumir que os alunos Têrena não manifestaram sua identidade étnica em um terreno comprovadamente hostil e adverso, com o claro receio de serem expostos, podendo tornar-se objetos de discriminação, "e que por certo teriam muito a perder, pois não se é 'bugre' impunemente no sul de Mato Grosso" (Cardoso de Oliveira, 2003, p. 128). Este cenário descrito pelo antropólogo apresenta similaridades com o que fora observado na EMEF Alcântara, com o detalhe de que o episódio acima descrito ocorreu há aproximadamente 50 anos, o que nos faz pensar que muito pouco tem se alterado em relação à visão do indígena nas escolas.

No entanto, apesar dessas dificuldades de identificação, pudemos verificar que alguns dos alunos indígenas afirmaram sua identidade étnica em razão dos direitos adquiridos por sua própria etnicidade, como podemos ver no seguinte depoimento: "Sou Pankararu e tenho oportunidade de estudar sem pagar". Isso é explicado pelo fato de uma universidade de São Paulo oferecer bolsas para que os Pankararu possam freqüentar a universidade, beneficiando, dessa maneira, diversos de seus membros, o que não deixa de ser percebido por seus colegas de escola, como podemos comprovar pela fala a seguir: "São estudiosos e recebem tratamento de saúde e faculdade de graça". Nesse sentido, assumir uma identidade Pankararu proporciona aos seus descendentes uma instrumentalidade social que contribuí para a afirmação étnica do grupo. Não podemos esquecer que o tratamento diferenciado que os indígenas Pankararu possuem na comunidade redunda, muitas vezes, em discriminações e preconceito. Para uma melhor compreensão a respeito disso, podemos utilizar um dos conceitos estabelecidos por Erikson: o "surrendered identity" ", que seria segundo Cardoso de Oliveira, "uma

\footnotetext{
74 "Gosto desta expressão porque ela não supõe uma ausência total - como ocorre em muitas obras contemporâneas - algo a ser procurado e descoberto, a ser concedido ou dado, a ser criado ou fabricado, mas outrossim, algo a ser recuperado. Isso deve ser enfatizado porque o que é latente pode converter-se numa realidade viva e constituir, assim, uma ponte do passado para o futuro" (Erikson, 1970, p. 298). O tradutor da obra Identidade - juventude e crise, de Erikson, para o português optou por traduzir o termo como "identidade resgatada", mas consideramos "identidade renunciada", tradução proposta por Cardoso de Oliveira, como uma opção melhor.
} 
identidade latente que é apenas 'renunciada' como método e em atenção a uma práxis ditada pelas circunstâncias, mas que a qualquer momento pode ser atualizada, invocada" (Cardoso de Oliveira, 2003, p. 124).

Com base nos estudos acima, podemos dizer que embora muitas propostas de mudanças curriculares na educação brasileira, como os PCN e a inclusão obrigatória das histórias e culturas indígena e afro-brasileira nos conteúdos escolares, arejem as discussões a respeito dessa temática, o que se observa na escola é uma realidade completamente diversa, pois esta se encontra mergulhada em sérios problemas estruturais e seus agentes, muitas vezes, não demonstram o menor interesse de que tais discussões adentrem nas salas de aula. Não é de se estranhar, portanto, que a discriminação étnica ainda prevaleça no interior desta escola, especificamente. Pode-se observar que essas iniciativas têm se mostrado insuficientes no combate à discriminação na escola sem que ocorra uma mudança de mentalidade dos próprios agentes escolares envolvendo a transformação em suas concepções e práticas pedagógicas - e sem a criação de condições para que o professor se desenvolva como um intelectual transformador, capaz de proporcionar voz ativa ao aluno para que este possa caminhar em seu aprendizado, livre das marcas do preconceito.

\section{Os alunos Pankararu a respeito de sua etnia}

Quanto às declarações dos alunos Pankararu a respeito de sua própria etnia, decidimos realizar uma análise mais detalhada dos questionários respondidos por eles, buscando conhecer com mais detalhes as visões de mundo, preferências e anseios de quatro alunas Pankararu.

\section{“Com os Pankararu, eu danço, canto, aprendo e, às vezes, ensino”}

Comecemos pela aluna Pankararu que denominaremos de G.I. Ela afirmou que tanto ela como sua família vieram de Tacaratu, Pernambuco. Apesar de não oferecer detalhes a respeito do total de membros da família, diz se dar bem com os pais e irmãos e descreve sua família como "legal", que gosta de ficar reunida nos fins de semana.

A respeito da escola, visualiza-a como um lugar de respeito e ensino, capaz de auxiliá-la a melhorar de vida e alcançar um futuro melhor. Em sua fala, lamentou o fato 
de seus pais não terem tido a mesma oportunidade de estudar que ela está tendo e observou que muitos dos alunos não estudam por causa da falta de vagas, enquanto outros, possuindo essa oportunidade, não valorizam o que têm. No entanto, sugeriu que houvesse mais espaço para manifestações culturais na escola.

Em relação à pergunta a respeito dos Pankararu, ela respondeu o seguinte:

Sim, sei muita coisa, sei que eles vieram de Pernambuco para encontrar uma vida melhor aqui em São Paulo, e realmente conseguiram, apesar das dificuldades. Conheço os costumes e crenças, praticamente sei muito, porque eu sou Pankararu, sou descendente de índia.

Quanto às manifestações culturais que observa deles, comenta: "Tem o movimento Pankararu e o Casulo. No grupo Pankararu, eu me identifico em tudo porque eu sou uma descendente. No Casulo, eu faço parte de um grupo de teatro, mas sei que lá tem um grupo de danças brasileiras, que tem a ver com as crenças e costumes do nosso país". No Casulo, além do teatro, também tem aulas de informática. Em relação à cultura Pankararu, mostrou-se bastante participativa: "Com os Pankararu, eu danço, canto, aprendo e, às vezes, ensino". Observamos aqui uma aluna que se identifica completamente com a sua própria etnia. Ela não demonstrou, em suas respostas, nenhum impedimento de se afirmar como uma descendente de indígenas e se mostrou estar muito atenta às tradições dos Pankararu, identificando-se plenamente com sua cultura tradicional, esforçando-se para aprender e praticar seus costumes e crenças. Além disso, também se prontificou a ensinar aos outros a respeito do que está aprendendo.

Embora atenta às tradições dos Pankararu, quando questionada a respeito de suas preferências musicais, apontou grupos de uma origem diferente da Pankararu, como os grupos $\mathrm{NX}$ zero e $\mathrm{Ne}-\mathrm{yo}^{75}$. A propósito do primeiro grupo ela destacou o seguinte trecho de música: "Tantas vezes você precisou e eu não pude ver nada além de mim, eu não deveria me explicar nem voltar atrás, pra te convencer, foi só no início". Esta música se chama “Além de mim”. Mesmo atenta às suas tradições, G.I. não deixa de interagir com outras manifestações culturais como o teatro e o rock, como se pode observar em suas preferências, o que demonstra que manifestações culturais diversas

\footnotetext{
${ }^{75} \mathrm{Nx}$ zero é uma banda paulistana de rock considerada alternativa, cujo público é formado basicamente por adolescentes. Ne-yo é um rapper norte-americano, além de compositor e produtor, cujas músicas possuem referências no hip-hop e no R\&B (rhythm and blues).
} 
podem conviver em um mesmo indivíduo. Desse modo, o conceito de aculturação, ou seja, a perda de traços de uma determinada cultura em razão da influência de uma cultura dominante, deve ser questionado, pois não apresenta ressonâncias com o que observamos nas respostas dos alunos Pankararu a esse questionário.

Ciente das dificuldades enfrentadas por ela e por seus pais em sua vida a São Paulo, parece se esforçar ao máximo para aproveitar as oportunidades de estudar, chance que seus pais não tiveram, observando que muitos de seus colegas valorizam a oportunidade que têm agora. Tem com objetivo se tornar uma professora que irá ensinar a respeito das culturas e crenças de todo o Brasil, principalmente dos indígenas e dos afro-brasileiros. É interessante observar que G.I. visualiza a escola como um local de transmissão de saberes tradicionais. Podemos presumir que é justamente pelo fato de perceber essa lacuna no aprendizado das culturas minoritárias presentes na sociedade brasileira é que G.I. formula seu objetivo de se tornar uma professora que terá um olhar atento às manifestações culturais de indígenas e afro-brasileiros.

Chama-nos a atenção, no caso de G.I., que o seu discurso difere e muito dos outros alunos Pankararu. Enquanto os outros alunos, em suas falas, se posicionam de forma bastante ambivalente em relação ao legado histórico-cultural de seus antepassados, ela demonstra estar completamente envolvida no aprendizado e perpetuação de sua cultura, costumes e tradições dos membros de sua comunidade.

\section{“Eu adoro a dança deles”}

A aluna Pankararu que denominaremos como E. não demonstrou um vínculo claro com esta tradição. Ela nasceu em Pernambuco, assim como seus pais e hoje tem 15 anos. Ela qualificou como "ótimo" o relacionamento que tem com a sua família, comentando inclusive que costumam assistir novela juntos.

Declarou que a dificuldade que enfrenta hoje é ver a mãe desejando retornar à sua cidade natal e não possuir recursos financeiros para realizar esse intento. Observa-se que, o que ela considera como dificuldade, está relacionado com a mãe e não consigo mesma. Observa-se, no caso, o desejo de regresso da mãe à sua terra, como um retorno às raízes, mas que não está sendo possível ser concretizado pelas dificuldades financeiras do momento. 
Como movimento cultural presente na comunidade, ela apontou o Projeto Casulo, identificando-se com a oficina de desenho como manifestação cultural, embora afirme que não participe de nenhuma das atividades culturais.

Sua preferência musical é pelo grupo "Bonde do Forró", revelando que a música de que mais gosta desse grupo é a que se chama "Garota de Programa", de cuja letra cita o seguinte trecho: "Deixei de ser garota de programa, deixei de ser uma qualquer, pois eu fiz com você loucuras na cama e o telefone peguei quem sabe um dia ligar". A banda "Bonde do Forró", como o próprio nome diz, toca músicas de forró e alcançou sucesso depois de se apresentar duas vezes no programa da Rede Globo Domingão do Faustão. Interessante notar que a música citada possui uma característica romântica, mas também uma forte conotação erótica, cujos apelos parecem precoces para a idade da aluna (15 anos). Percebe-se, nesse sentido, a influência que os meios de comunicação de massa têm exercido sobre os jovens, principalmente a televisão e o rádio.

A respeito da escola, mencionou que encontra espaço para se manifestar culturalmente, mas que não é suficiente, sugerindo que se ensinem danças e artes plásticas. Imagina para ela um futuro maravilhoso, tendo como objetivo ser desenhista.

A respeito dos Pankararu, declarou:

Eu conheço os Pankararu mais ou menos. Meu pai e minha mãe são Pankararu. O que eu sei sobre eles é que eles vieram de Pernambuco e lá no Norte eles comem com a mão. E eu adoro a dança deles.

O que podemos notar é uma relação ambivalente, em nível de discurso, entre E. e os membros da comunidade Pankararu (oposição “eu” x “eles”). É como se não houvesse um sentimento de pertença à sua comunidade, embora afirme adorar a dança que os membros da comunidade praticam. Chama a atenção nessa fala a referência ao fato de que "comem com a mão", o que pode parece ser algo relevante em sua memória a respeito dos Pankararu, uma realidade com a qual provavelmente não conviva mais. Observa-se na frase "eu adoro a dança deles" certos laços afetivos que a vinculam aos costumes dos Pankararu, embora desconheça o sentido deles, como se houvesse um truncamento da passagem dos conhecimentos tradicionais de uma geração à outra.

\section{“Eles cantam em outra língua”}


Outra aluna nos leva a pensar em outro modo de relacionar-se com a tradição. A aluna M.D. nasceu em Piranhas (Alagoas), enquanto a mãe nasceu em Recife (Pernambuco). Afirmou que possui um bom relacionamento com sua mãe e seus três irmãos, qualificando-os como pessoas humildes e legais, não fazendo nenhuma referência a seu pai, ausente.

Como movimento cultural presente na comunidade, apresentou o Projeto Casulo e a informática, afirmando ser neste curso onde é mais participativa, a ponto de ajudar outros alunos nestas atividades. Interessante observar que a informática e, conseqüentemente, a Internet sejam qualificadas como movimentos culturais. Fica implícito que essas duas modalidades tornam-se uma espécie de porta de entrada a um mundo de informações e oportunidades de conhecimento que não seria acessível de outra forma.

Como gosto musical, apresenta o grupo Rebeldes, destacando o seguinte trecho de música: "Meu pai me chama outra vez, como viver o meu futuro em paz com esse jeito de ser". O fato de destacar este trecho da música pode ser algo muito significativo, uma vez que se nota, nesta letra de música, a referência ao pai, que não está presente em sua vida.

Ela observou que não há espaço na escola para manifestações culturais e afirmou a necessidade de uma mudança em seu modo de funcionar, insistindo para que os professores não faltem, uma vez que este é um problema recorrente na escola.

A respeito dos Pankararu, comentou:

Sim, eu sou descendente. Eu sei que eles falam normal, mas, quando eles vão cantar, eles cantam, cantam em outra língua, e às vezes eles fazem cerimônias aos sábados. Só às vezes.

Embora afirme ser descendente da etnia Pankararu, novamente observamos o distanciamento no plano discursivo, com uma atenção especial à frase "eles falam normal". A "fala normal" é a própria língua portuguesa, uma vez que a etnia perdeu o seu idioma nos tempos coloniais, mas ainda utilizam o que se crê serem termos da língua ancestral em seus cantos rituais. Outra questão são as cerimônias que são realizadas nas próprias casas, que são diferentes do Toré, que é mais utilizado como uma manifestação pública. 


\section{“As comidas deles não são diferentes das nossas"}

Vejamos como outra jovem se vincula à tradição Pankararu. G. nasceu em São Paulo, enquanto a mãe, já falecida, nasceu em Minas e o pai, em São Paulo. Ela mora com seus dois irmãos por parte de mãe, e o pai não mora mais com eles. Qualificou o relacionamento com seus irmãos como bom, comentando que seus irmãos são muito cuidadosos para com ela.

A escola representa para ela uma oportunidade de um futuro melhor, mas relatou as dificuldades de encontrar uma escola na qual os professores compareçam. Espera uma escola que dê mais atenção aos alunos e tenha respeito para com eles, proporcionando-lhes um diálogo maior. Comentou também a dificuldade de fazer uma faculdade, embora enxergue nela a oportunidade de arrumar um bom emprego.

Em relação aos movimentos culturais, ela se identifica com a dança e faz balé. Pretende prosseguir nos estudos de balé e ser uma bailarina.

Quanto aos Pankararu, disse:

Sim, eu sou descendente deles. Os Pankararu sempre fazem festa no dia do índio. Sempre há danças na quadra do projeto Casulo. Eles falam as mesmas línguas que nós, as comidas deles não são diferentes das nossas.

Novamente observa-se a afirmação de que é descendente de Pankararu, mas também observamos uma relação ambivalente em relação à sua etnia, uma vez que há oposição entre "eles" (Pankararu) e "nós", demonstrando que não está presente, pelo menos no discurso, uma relação integral de pertencimento de sua parte em relação aos Pankararu. O seu depoimento nos mostra uma visão que a língua e a alimentação poderiam apresentar certo diferencial em relação a outros grupos em termos culturais e étnicos. Chamou-nos a atenção o fato de ela estar bastante envolvida com uma dança o balé clássico -, embora distante das danças de sua etnia.

\section{Observações gerais sobre as alunas Pankararu}

Antes de tudo, temos de compreender que estamos tratando de alunos da etnia Pankararu que estão em um contexto urbano. Dentre as alunas pesquisadas, apenas uma nasceu em São Paulo, enquanto as outras nasceram na Terra Pankararu e as que não 
nasceram na Terra Indígena, tiveram pais oriundos de lá. Podemos observar nesses depoimentos das alunas Pankararu que a identificação plena com a cultura indígena difere de indivíduo para indivíduo. Observamos uma aluna que, em seu discurso, demonstra estar totalmente integrada à cultura de seus antepassados, assumindo um compromisso com o aprendizado e o ensino de seus costumes e crenças, sem deixar de se envolver com outros elementos culturais. No entanto, o que podemos perceber nas outras alunas é um relacionamento ambivalente ou até certo distanciamento em relação à sua própria etnia, pelo menos no plano discursivo, aparentando que elas conhecem pouco de sua cultura de origem. Isso nos mostra quão delicado é fazer generalizações, uma vez que cada indivíduo pesquisado representa todo um universo a ser investigado em sua singularidade.

Ao contrário do que um pensamento etnocêntrico poderia indicar, entre as alunas Pankararu não existem conflitos entre gêneros musicais, como o forró, o rock e mesmo músicas para adolescentes e a música tradicional Pankararu. Do mesmo modo, há um envolvimento ou, pelo menos, um desejo de envolvimento com manifestações culturais, como o teatro, a dança e o desenho. Não há exatamente, por parte dos alunos pesquisados, uma referência aos costumes Pankararu, o que nos faz pensar que há uma concepção diferente de cultura por parte dos Pankararu. Podemos presumir que o que muitas vezes qualificamos como cultura, para os indígenas Pankararu estaria relacionado com questões do cotidiano, ou aspectos de sua religiosidade ou mesmo demonstrações de sua identidade étnica.

Essas questões nos levaram a realizar uma investigação de maior profundidade, apontando para a necessidade de realizarmos intervenções em classe e entrevistas, por meio das quais nos seria possível adentrar na realidade vivida por estas alunas. 


\section{A metodologia das intervenções}

As intervenções tomaram como base teórica os pressupostos gerais do Projeto Culturas Juvenis, que propõe uma metodologia que consiste em utilizar uma espécie de etnografia do olhar que possa se abrir para o "sentir polissensorial", em que se articulam as dimensões estética e antropológica, dando ensejo ao que os antropólogos chamam de "olho participante" (em que o pesquisador se põe a olhar e, ao mesmo tempo, deixa-se olhar), conceito fundamental tanto para repensar o método de pesquisa como para a leitura das culturais juvenis, tão ricas em manifestações "polifônicas" e "polissensíveis" (cf. Amaral, 2007).

De acordo com Canevacci (2000), para uma realidade polifônica é necessária a criação de uma metodologia de pesquisa que seja também polifônica.

Assumir a polifonia como questão metodológica significa transitar de uma forma de escritura unitária a uma forma de representação plural (...) A polifonia está no objeto e no método. Transita e rompe as fronteiras definidas entre estes dois mundos e os transforma em subjetividades que dialogam entre si, se conflituam, que constróem dissonâncias cognitivas (Canevacci, 2000, p. 131).

Inspirados nessas reflexões e articulações, procuramos adotar o "olho participante" como método de investigação na escola. Com isso, pretendíamos romper e renovar em seu interior a razão reinante na cultura escolar sustentada pelo sistema de ensino (que inclui professores, coordenadores, diretores e funcionários das secretarias de ensino) por meio do contato com os elementos mais críticos e transformadores das culturas juvenis e étnicas, que são portadoras das vozes marginalizadas da escola e, por que não, da sociedade. Para que isso ocorresse, tornar-se-ia necessário que não apenas os pesquisadores universitários adotassem este "olho participante", mas também o corpo docente da escola, em especial os professores, que estão em constante contato com os alunos.

Nesse sentido, consideramos importante trazer a contribuição de Henry Giroux (1988) a respeito do papel do professor como um intelectual transformador. Para estabelecer a posição do professor como intelectual, este autor se utiliza da conceituação de "intelectual" sustentada por Antonio Gramsci, que amplia em muito a noção de intelectual, não se restringindo àquela que se atém apenas aos chamados grandes 
intelectuais. Para Gramsci (1968), não há atividade humana da qual se possa excluir toda intervenção intelectual, não havendo como separar o homo faber do homo sapiens. Ainda para este autor, cada indivíduo realiza certa atividade intelectual e participa de uma visão de mundo, possui uma linha consciente de conduta moral e, por isso, contribui para sustentar ou para modificar uma concepção de mundo, transformando novas formas de pensamento em realidade. "Todos os homens são intelectuais, poderse-ia dizer, mas nem todos os homens desempenham na sociedade a função de intelectuais" (Gramsci, 1968, p. 7). A tarefa primordial dos intelectuais transformadores, segundo Giroux (1988) seria, então, inserir a educação no plano político, transformando a escola em um espaço social que auxiliasse os educandos a desenvolver uma firme convicção na luta pela transformação individual e social e para a superação das injustiças e desigualdades na sociedade. E também utilizar as formas pedagógicas que auxiliassem os alunos a se tornarem indivíduos críticos, ou seja, capazes de dialogar de forma crítica com o conhecimento, a ponto de serem capazes de se emancipar. Isso implicaria na questão de que os intelectuais transformadores deveriam proporcionar voz ativa aos alunos em seu aprendizado, tornando-os assim agentes sociais e coletivos, cientes, tanto de sua inserção (...) de suas classes sociais, culturas, raças e gêneros, quanto de seus desafios e expectativas de vida.

Devemos ressaltar ainda o grande paradoxo pelo qual os intelectuais transformadores se deparam, pois atuam oferecendo aos estudantes discursos alternativos e práticas críticas em um sistema educacional que exerce um papel fundamental na reprodução da cultura dominante. Um paradoxo de difícil resolução, mas que aponta para a necessidade dos educadores buscarem uma compreensão do papel de intelectual transformador no tocante ao emprego da linguagem crítica e transformadora, capaz de indicar as condições necessárias para a produção de novas formas de cultura e práticas sociais e novos modos de comunicação. Desse modo, esses intelectuais podem colocar em evidência os mecanismos de funcionamento do poder na escola, apontando suas contradições e indicando como explorar suas brechas de forma a fazer com que a escola se torne um campo de luta política e cultural.

Ao "olharem e deixarem-se olhar", tanto pesquisadores como professores, atuando como intelectuais transformadores, poderiam constituir comunidades

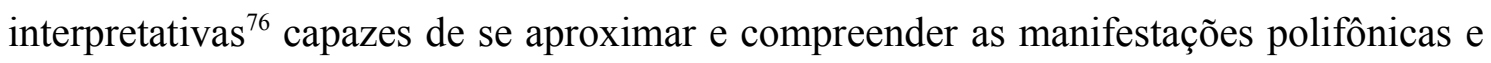

\footnotetext{
${ }^{76}$ Comunidades interpretativas, segundo Boaventura de Sousa Santos (2005), seriam comunidades que, por meio de "uma abertura ao outro" e do esforço dialógico e argumentativo de seus integrantes, possibilitariam uma re-conceituação de práticas e currículos no interior de uma instituição, no caso, a
} 
polissensoriais das culturas juvenis e étnicas presentes em sala de aula, de modo a se permitirem rediscutir as noções de autoridade e disciplina, os currículos escolares e as práticas de ensino e assim criar as condições para a mudança de suas próprias condutas e o aprimoramento da qualidade das relações no interior da escola.

Tomando com base esta metodologia, as intervenções foram desenvolvidas tendo dois enfoques: 1) observar como a cultura tradicional dos alunos Pankararu estaria se manifestando e se relacionando com outros tipos de culturas juvenis e a própria cultura escolar; 2) discutir as questões da discriminação e preconceito entre os alunos na sala de aula e com os professores nas reuniões posteriores. Vale ressaltar que as temáticas da discriminação e o preconceito foram sugeridas pelos próprios professores em decorrência da análise geral dos questionários. As intervenções, de certo modo, buscavam instituir um espaço de diálogo dentro da própria escola, sem nenhuma espécie de coação institucional sobre os alunos e um momento em que os alunos poderiam se manifestar em todos os sentidos. Desse modo, as intervenções e as reuniões abririam caminho para que os próprios professores, no contato com os alunos e com todo um referencial teórico a respeito da condição indígena e das questões do preconceito e discriminação, pudessem refletir e transformar suas concepções, práticas pedagógicas e relacionamento com os alunos. Uma questão central surgida na análise dos questionários e, posteriormente, nas intervenções foi o preconceito e a discriminação vivenciadas não apenas no bairro, mas em sua própria escola. Daí a importância de nos determos neste tema.

\section{A preparação para as intervenções}

Nas reuniões iniciais, a pedido dos professores, fizemos um breve relato da trajetória do nosso projeto de pesquisa, partindo do estudo realizado na iniciação científica até o mestrado, e de como fomos nos interessando pelos estudos sobre as origens e a vida dos indígenas Pankararu em São Paulo. Relatamos também que o projeto estava inicialmente voltado para a comunidade fora da escola, mas, verificando o contexto escolar, decidimos direcionar as pesquisas para os alunos Pankararu presentes neste ambiente, em razão da dificuldade dos mesmos assumirem sua identidade étnica. Inicialmente, realizamos uma análise detida dos questionários

Universidade. Acredito que as comunidades interpretativas possam ser efetivas também no interior da própria escola. 
respondidos pelos alunos da $7^{\mathrm{a}} \mathrm{B}$, de modo que fosse obtido um quadro mais claro da visão dos alunos que não eram de ascendência indígena em relação aos alunos Pankararu e da que os próprios alunos Pankararu tinham a respeito de sua etnia. Com base nesta análise, o subgrupo de pesquisa teve elementos para delinear as temáticas que seriam abordadas nas intervenções em sala de aula.

Neste período chamou a atenção dos professores a dificuldade que os jovens alunos apresentavam de reconhecer a si próprios como indígenas. Os professores relembraram, na reunião, as atividades ${ }^{77}$ que anos atrás para auxiliar os alunos Pankararu e que geraram muitos resultados, mas que não tiveram seqüência em virtude de diversos problemas estruturais da escola (assim se referem à falta de apoio, inclusive de material, por parte da diretoria). A professora C. comentou que havia se surpreendido com a dificuldade dos alunos Pankararu de se identificarem como indígenas, como se todo o trabalho realizado anteriormente não tivesse gerado frutos. Isso nos fez refletir que o trabalho de inclusão dos indígenas na escola não deveria ser uma iniciativa isolada de alguns poucos professores, mas sim um trabalho que envolvesse a escola como um todo e que fosse algo pertencente à própria cultura escolar. Pudemos perceber, a partir desta discussão, que iniciativas isoladas tendem a não ter seqüência a não ser que a cultura escolar acolha as culturas minoritárias, isto é, que não seja priorizada apenas a cultura dita "letrada", "erudita" ou "culta", mas que se tome em consideração a realidade cultural dos alunos presentes na própria escola.

Um episódio especialmente contribuiu para nossa reflexão. A professora P., que atua desde as primeiras séries até a $8^{\mathrm{a}}$ série, comentou que alguns alunos Pankararu que haviam chegado há pouco do Nordeste estavam com problemas de adaptação. Por essa razão, foi sugerido que eles recebessem acompanhamento psicológico. Então a mãe foi chamada e aconselhada para que fosse feito este encaminhamento. A mãe respondeu, no entanto, que era necessário falar com a FUNAI antes a respeito do assunto. Nesse caso, pudemos observar um choque entre uma cultura tradicional e um campo científico, como a psicologia. De um modo geral, a análise realizada trouxe diversos elementos para a reflexão do grupo de professores e, juntamente com as discussões realizadas nas reuniões, iniciamos as intervenções na classe pretendida: a $7^{\mathrm{a}} \mathrm{B}$. Neste momento, consideramos importante trazer alguns elementos destas análises para uma melhor compreensão do andamento das intervenções.

\footnotetext{
${ }^{77}$ Pelo depoimento dos professores, foram realizadas atividades como peças de teatro e jograis para que os alunos se identificassem como indígenas na escola.
} 
Em uma outra reunião de preparação com os professores, foi-nos sugerido que trabalhássemos as questões da discriminação e do preconceito com a classe; temáticas que consideramos pertinentes em virtude das análises feitas dos questionários, para depois realizar um trabalho mais voltado propriamente aos alunos Pankararu.

\section{Racismo, preconceito, discriminação}

Torna-se pertinente, nesse momento, que realizemos uma discussão a respeito das questões de racismo, preconceito e discriminação. Segundo Segato (2006), uma definição jurídica, considerada como um marco para a compreensão e denúncia do racismo, foi formulada pela CERD (Convenção Internacional para a Eliminação de todas as formas de Discriminação Racial), adotada pela Assembléia Geral da ONU em 1965, tornando-se vigente a partir de 1969. A CERD define a discriminação racial como "qualquer distinção, exclusão, restrição ou preferência baseada em raça, cor, descendência ou origem nacional ou étnica que tenha o propósito ou o efeito de anular ou prejudicar o reconhecimento, o gozo ou o exercício em pé de igualdade dos direitos humanos e das liberdades fundamentais" (CERD, 1969, s/p). Essa definição abre caminho para a identificação dos atos racistas, tornando-se o primeiro passo para compreender o fenômeno em suas diversas facetas e permitindo uma maior conscientização a respeito do assunto tanto por parte dos que são vitimados por estes atos como quanto por parte daqueles que os praticam. Como um passo posterior, tornouse então imprescindível inserir essa discussão no currículo das escolas e no interior das instituições de forma que fosse possível problematizar as mentalidades e práticas racistas e adotar medidas que pudessem corrigir e eliminar as distorções produzidas por elas.

Uma distinção fundamental a respeito deste assunto é a que se refere à diferença entre racismo como preconceito ou como discriminação. $O$ preconceito pode ser considerado como uma atitude racista de foro íntimo, proveniente de convicções pessoais, a respeito de pessoas não-brancas em geral. "Para existir, o preconceito racial necessita e se alimenta da diferença, quer dizer, da produção de alteridade a partir de traços visíveis como as que podem ser fixadas como indicação de outras - supostas diferenças não-visíveis" (Segato, 2006, p. 3, tradução nossa). Isso implica dizer que o preconceito acaba se nutrindo da constante produção de estigma. 
Já a discriminação é o resultado dessas convicções pessoais na esfera pública, ou seja, a negação do acesso a recursos, serviços e direitos disponíveis no espaço público a membros do grupo humano vitimizado pelo racismo, seja de forma consciente e deliberada ou não. "A discriminação consiste em oferecer oportunidades e tratamento negativamente diferenciados a pessoas sobre as quais recai o preconceito racial, o que acaba por restringir seu acesso ao pleno usufruto de recursos, serviços e direitos" (Segato, 2006, p. 3, tradução nossa).

É essencial que se observe que o tratamento negativamente diferenciado pode ocorrer simplesmente pelo fato de não se realizar nenhum gesto de atenção específica a pessoas que necessitem dessa atenção, enquanto esta mesma atenção é dispensada para pessoas de um grupo não discriminado. Desse modo, o preconceito se transforma em um hábito, fixando-se nas mentalidades e ocultando uma história e um cenário social estratificado racial e etnicamente, que é capaz de se criar e se reproduzir, transformando-se conseqüentemente em uma espécie de natureza irremovível e ahistórica. Esse meio social reproduzido retro-alimenta o preconceito pessoal, ao permitir imaginar que as desigualdades existentes possuem uma razão de ser devido a supostas qualidades "naturais" que determinam a inferioridade das posições sociais dos que não são brancos (cf. Segato, 2006).

\section{Os tipos de racismos}

Segundo Segato (2006), podemos dizer que existem pelo menos quatro tipos de racismo:

1. Um racismo de "convicção", axiológico: demonstrado por uma série de convicções e valores explícitos que atribuem predicados negativos (ou positivos) em razão da cor, características físicas ou grupo étnico ao qual a pessoa pertence;

2. Um racismo político-partidário-programático: que fundamenta a formação de grupos políticos que atuam de forma mancomunada e estabelecem um antagonismo aberto contra setores da população racial ou etnicamente marcados;

3. Um racismo emotivo: que manifesta sentimentos como medo, amargura ou ressentimentos com relação a pessoas de outra raça ou grupo étnico. 
4. Um racismo de "hábito", automático e irreflexivo: culturalmente estabelecido e naturalizado, ele não chega a ser reconhecido ou demonstrado como atribuição explícita de valor diferenciado a membros de grupos raciais e étnicos.

Cabe observar que o último destes quatro tipos pode ser considerado o que mais ocorre em nosso continente e, apesar de ser apresentado como a forma mais ingênua e bem-intencionada de racismo, é uma das mais letais, pelo fato de produzir mais vítimas na convivência diária e, especialmente, na vida escolar. Este tipo de racismo se opõe aos que são fundamentados em uma consciência discursiva e justamente por ser silenciosa e sutil, é que se torna mais difícil dele se defender e combater, tornando-se então uma prática estabelecida e naturalizada.

No entanto, é apenas por meio das estatísticas sociais que se observa o alcance e as conseqüências dos gestos e atitudes rotineiras do racismo, principalmente no âmbito escolar. Ele se torna o filtro de estudantes indígenas e afro-brasileiros, que são impedidos de progredir no sistema escolar e universitário sem que possam sequer reconhecer e denunciar quem os prejudica. As conseqüências são visíveis quando se observa que, na sociedade brasileira, os espaços de maior prestígio e poder da sociedade e as profissões mais valorizadas estão sempre ocupados por pessoas brancas em detrimento das pessoas não-brancas.

\section{O início das intervenções}

Como não havia sido feita nenhuma atividade por parte do projeto de pesquisa na $7^{\mathrm{a}} \mathrm{B}$, a professora $\mathrm{C}$. ponderou que seria melhor realizar inicialmente intervenções que tivessem como temática: “o que é ser adolescente hoje?" e o "mundo da escola $\mathrm{x}$ mundo fora da escola". Então, iniciamos a primeira intervenção com a seguinte temática para os alunos: "O que é ser adolescente hoje?". Depois das devidas apresentações da equipe de intervenção à sala, o professor L. iniciou as atividades fazendo a seguinte pergunta para os alunos: “O que é ser jovem?”. Em suma, quais eram as questões que eles enfrentavam como adolescentes?

Os alunos foram respondendo à questão e o professor L. anotando na lousa as frases e palavras ditas pelos jovens: "adrenalina”, “coragem”, “insegurança", "liberdade", “justiça", "preconceito", “fidelidade", "racismo", "preguiça", 
"irresponsabilidade", "sexualidade", "amor", "drogas", "respeito", entre outras. Embora tivéssemos planejado de antemão tratar da questão do preconceito e discriminação e depois a temática Pankararu com os alunos, não comentamos com a classe que iríamos tratar destes assuntos. Desse modo, chamou a atenção os termos "preconceito", "racismo" e "justiça" aparecerem de forma contundente entre os alunos.

Iniciamos uma pequena discussão a respeito desses tópicos e depois pedimos aos alunos que se dividissem em grupos e escrevessem e desenhassem em cartazes a respeito dos temas mencionados por eles. Foi interessante notar que a maioria dos grupos se formou somente com meninas e outros somente com meninos, e apenas dois foram agrupados de forma mista. Uma divisão que demonstrava certo antagonismo entre os alunos dos sexos masculino e feminino. Tanto era assim que em um dos grupos mistos, houve provocações mútuas entre um aluno e uma aluna, que acabou comprometendo o andamento do trabalho deles. Em outro grupo, observamos que os alunos praticamente haviam dividido mentalmente o cartaz em quatro partes, e cada um dos alunos trabalhava em seu espaço demarcado. O resultado não foi exatamente uma criação coletiva, mas sim um mosaico de trabalhos isolados.

À medida que os cartazes foram sendo feitos, a equipe pôde notar que os temas "preconceito", “discriminação" e "justiça” estavam sobressaindo nos cartazes. Para se ter uma idéia de como esses temas foram abordados pelos alunos, transcreveremos um cartaz que chamou nossa atenção. Segue sua transcrição:

O que é ser jovem?

Todo jovem precisa de amor e carinho, mas todo jovem pensa em várias outras coisa como por exemplo amar, bincar, drogas e várias outras coisas.

É muito bom também pensar em sertos preconceitos: preconceitos a cor, preconceitos do trabalho e várias outras coisas.

O jovem pensa em curti e se divertir então por isso devemos pensar - sempre o serto e não o errado pense bem antes de fazer alguma besteira ok! ${ }^{78}$

O texto apresenta um quadro muito claro das necessidades dos alunos, como o amor e o carinho, mas também o anseio por "brincar", "curtir" e se "divertir", desde que realizado com responsabilidade, como podemos ver na frase: "pense bem antes de fazer alguma besteira ok!". Chama atenção a referência às drogas, ao lado das palavras

\footnotetext{
${ }^{78}$ Mantivemos a grafia original do texto.
} 
"amar" e "brincar", demonstrando que essa questão é uma realidade vivida pelos alunos, dada a proximidade com o mundo do tráfico de drogas na comunidade em que moram. Também destacamos a frase: "É muito bom também pensar em certos preconceitos: preconceitos de cor, preconceitos de trabalho e várias outras coisas". Uma frase marcada por relativa ambivalência, pois a expressão "é muito bom" aparece ao lado de algo que os fere muito: o preconceito. Observamos na frase "preconceitos de cor, preconceitos de trabalho" uma situação crítica e cruel: se pensarmos que o preconceito se refere a um plano das idéias, o que eles estavam presenciando e sentindo de fato era uma discriminação em relação à cor e em relação ao acesso ao trabalho. Na realidade, isso é um retrato das condições vividas na comunidade em que moram: o fato de serem discriminados por serem afro-brasileiros e indígenas, por morarem em condições precárias em uma comunidade pobre, converte-se em um estigma que estaria minando as possibilidades de ingresso no mercado de trabalho, tanto dos jovens quanto de seus familiares. Esse quadro dramático se torna mais surpreendente pelo fato de, no mesmo cartaz, ter sido desenhada uma mãe loira segurando uma criança e com um olhar bastante triste em estilo mangá $a^{79}$, aliás, em um estilo estético impecável. De certa forma, podemos observar o quanto essa discriminação estava sendo interiorizada, pois o retrato de uma mulher triste não era de uma mulher afro-brasileira, mas sim uma visão dominante de certo ideal de mulher veiculado pelos meios de comunicação.

\footnotetext{
${ }^{79}$ Foi interessante notar que alguns alunos desenhavam em um estilo japonês chamado mangá. Eles comentaram fazer curso de desenho no Projeto Casulo, que promovia oficinas de desenho. Isso nos chamou a atenção, pois desenhavam feições orientais nos personagens, no entanto os alunos eram, em sua maioria, afro-brasileiros. As feições orientais mostradas no desenho nos alertaram para uma situação paradoxal. Um processo que poderíamos chamar de "orientalização" por parte dos alunos, que são, em sua maioria, negros. Segundo Piza (2005), a "branquidade" é vivenciada cotidianamente como reflexo de uma relação de poder que só se manifesta em momentos nos quais é impossível ignorar a presença do outro "diferente". Desse modo, a "branquidade", como expressão social e cultural hegemônica, no mundo ocidental, conforma traços das identidades de brancos e negros, igualmente. Para brancos, a "branquidade" incorpora traços de racismo, mesmo quando não consciente, não manifesto ou reprimido. Para afro-brasileiros apresenta-se como uma barreira para a construção de uma identidade racial positiva (a negritude), já que os modelos de humanidade positiva são brancos. Desse modo, penso que é em razão de uma barreira para a construção da negritude como uma identidade racial positiva que os alunos acabam por desenhar personagens em estilos orientais, sem retratar a si mesmos como negros. No entanto, falamos de um processo que não pode ser interpretado como branquidade, mas sim de "orientalização". Em que medida, de certa forma, o ideal de feições orientais mostrado nos animes e quadrinhos não estaria assumindo um lugar nas mentes dos jovens, também impedindo que se construa a negritude ou indianidade como identidade racial positiva. Surge também a necessidade de verificar se, de fato, está havendo uma influência maciça dos meios de comunicação no sentido de configurar essa imagem ideal ou não.
} 


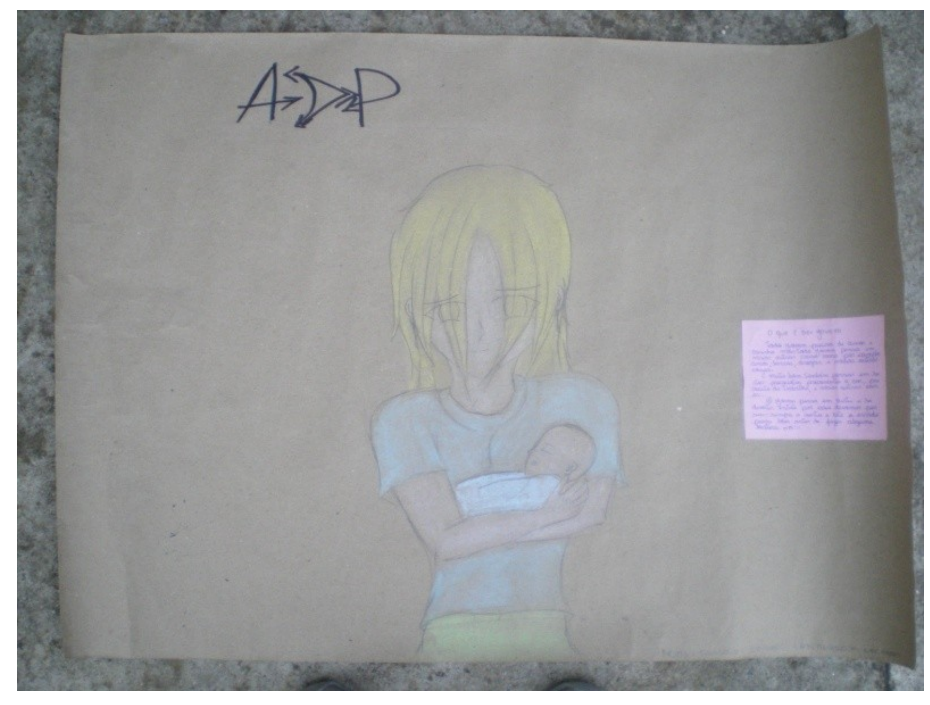

Notamos também que a palavra justiça era recorrente nos cartazes, do mesmo modo que idéias e sentimentos associados ao preconceito. A seguir, citamos algumas frases presentes nos cartazes:

"Não existe justiça, mas somente vingança";

"O mundo precisa de mudanças";

"Somos todos iguais".

Essas frases nos fizeram pensar se esse grito/denúncia recorrente não seria um apelo aos adultos para que ficassem atentos ao preconceito e à falta de justiça no tratamento dado a eles, pela escola inclusive, demonstrando a consciência que os alunos tinham a respeito de sua situação perante a escola e o mundo em que vivem.

Na reunião realizada com a equipe, pudemos discutir o conteúdo dos cartazes e observar que, realmente, as questões relativas ao preconceito, à discriminação e à injustiça estavam bastante em evidência entre os alunos. Desse modo, optamos por não abordar a temática "Mundo na escola x mundo fora da escola" e trabalharmos diretamente com a questão da discriminação.

$\mathrm{Na}$ segunda intervenção, o professor L. elaborou um texto sobre discriminação para ser lido em classe para ajudar os alunos a pensar sobre o assunto. A seguir transcrevemos o texto:

Racismo, Preconceito, Discriminação ${ }^{80}$

\footnotetext{
${ }^{80}$ Texto da autoria do Prof. Silas Correa Leite.
} 
- Você já passou por isso?

- Ou já fez outros passarem?

- Você pratica, luta contra ou não está nem aí?

De uma forma ou de outra, existe o preconceito: porque é pobre. Ou porque é negro... Ou porque é nordestino... Ou porque é roqueiro... Ou porque é índio... Ou porque parece culpado, sabe como é, a roupa, o cabelo, o RAP... Já pensou? E a discriminação no supermercado, na praça dos ricos, na fila. Tem de tudo.

Nós temos um nome. Devemos nos orgulhar de nossas origens: de nossas raízes. Nossos pais tiveram avós, nós teremos netos.

Então como é que fica essa coisa de racismo, que é crime, ou de sermos discriminados?

Preconceito é crime, mas quem que liga pra isso? Pois é. Eu ligo, você liga, estamos ligados... Quando os brancos portugueses chegaram, quem estava aqui nesse continente que nem chamava Brasil ainda? Os índios. Isso é história. Depois vieram os negros e foram explorados. Hoje, a cultura negra é forte no Brasil, mas os negros ainda são discriminados. Como pode ser isso? O branco, sem saber, curte essa cultura, o som, até tipos de comida de afro-descendentes, mas não sabem. Falta de cultura? E os índios então? Quanto de nossa cultura tem essas raízes! Palavras ricas: Anhangabaú, Ibirapuera, Morumbi. Tudo palavra indígena. Então os donos do Brasil deveriam ser os índios? Pois é. O Brasil é essa mistura.

Quem conhece a história, conhece a lei, tem cultura, não tem preconceito, não discrimina. Qual é a sua? Você conhece algum índio? Pois é: destruíram as terras deles, mataram milhões deles e eles ainda são discriminados. Eu, por exemplo, tenho pai de origem judia e portuguesa, e a minha adorável mãe, que é a minha força e a minha fortaleza - quem tem mãe não tem medo - tem uma origem de negro com índio. Então, como é que fica?

Devemos rotular alguém? A primeira coisa que recebemos ao nascer, como um documento-identidade, é o nosso abençoado nome. Somos a nossa cor, a nossa origem, e o que fazemos disso? Nem discriminar e nem aceitar discriminação. Qual é a sua, cara, assuma-se sendo o que você é. No Brasil é essa mistura mesmo. Racismo não tem nada a ver. Preconceito é coisa de quem não se 
enxerga. E discriminação tem a ver com a ignorância de quem discrimina. Somos da Raça Humana. Se pudéssemos arrancar a pele de todos, seríamos todos VERMELHOS. Você é a cara e a coragem que você tem. E você é tudo o que você tem. O que você vai fazer disso? Eu por mim quero ter um filho chamado Taiguara (nome indígena que é lindo), morar no Morumbi, curtir samba ou blues (origens negras), e não estar me preocupando se sou branco, negro ou azul, mas de que EU sou e devo me parecer muito com GENTE, Ser Humano. Já pensou?

A professora P. fez a leitura do texto na sala e os alunos acompanharam. Em seguida, o professor L. esboçou na lousa alguns aspectos que foram abordados nos cartazes, em especial a discriminação e o preconceito para dar início ao debate com os alunos. Este mesmo professor comentou, então, que debaixo da pele somos todos vermelhos, não importando nossa cor. Queria dizer com isso que somos vermelhos por causa do sangue que circula em nossos corpos e nos constitui como seres vivos e humanos. Ele perguntou à classe quem já tinha passado por discriminação. Os alunos não levantaram as mãos, talvez ressabiados ou tímidos. Foi interessante observar que eles, em um primeiro momento, não conseguiam verbalizar os sentimentos a respeito da discriminação e do preconceito. É como se a realidade estivesse tão presente e dolorosa a ponto de não permitir traduzi-la em palavras.

Para auxiliar os alunos, a professora P. comentou que, em certa ocasião, foi fazer compras no shopping e foi discriminada por causa das vestimentas que estava utilizando, uma vez que estava com a roupa de trabalho. Depois a professora A. pediu a palavra e disse que a discriminação podia acontecer dentro da própria casa, quando mesmo a família muitas vezes desqualificava um dos seus, chamando-os de "burros" e outros termos. De certo modo, com esses comentários, os professores buscavam se colocar em situações que julgavam serem parecidas com as que os alunos passavam, mas era nítido que as realidades vividas pelos alunos era muito mais difícil e complexa, o que explica, de certo modo, o silêncio em sala de aula.

Como etapa posterior da intervenção, pedimos que os alunos se reunissem novamente em grupos para que expressassem nos cartazes os seus pensamentos e sentimentos a respeito da temática "Preconceito e Discriminação".

Um grupo de meninos não estava muito disposto a realizar o trabalho, mas pouco a pouco começaram a fazer as atividades. O menino desenhou três pessoas - um indígena, um negro e um branco - presos a uma corrente, em cima de um quadrado que 
estava escrito: "caixa de discriminação, preconceito e racismo". Ele acabou por desenhar no cartaz uma versão maior, enquanto o outro aluno copiou uma parte do texto em uma folha para ser colada no cartaz, que continha os seguintes dizeres:

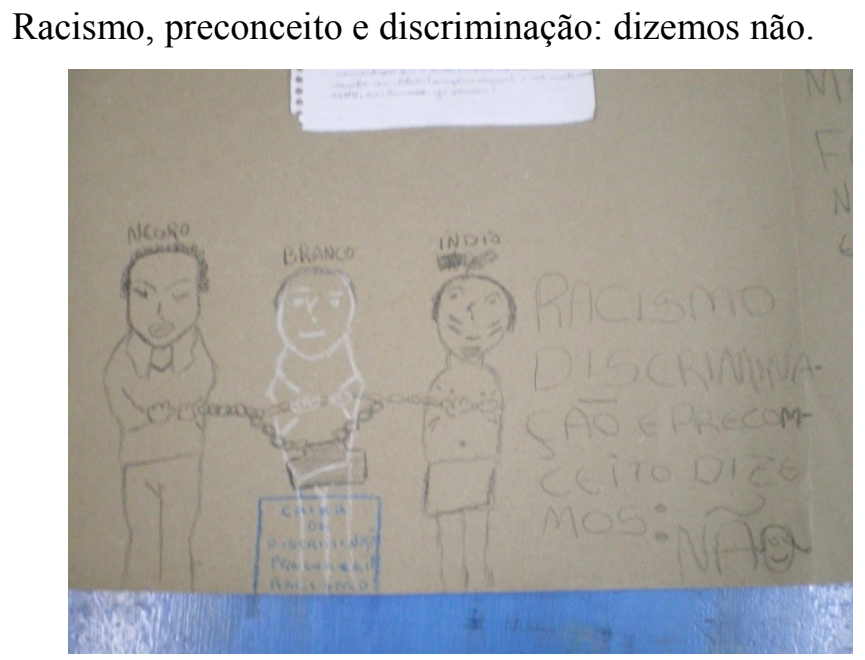

Interessante notar no desenho do aluno a representação de dois grupos de indivíduos historicamente discriminados no Brasil - o indígena e o afro-brasileiro - e a de um grupo majoritariamente discriminador - o branco. Observamos ainda que ambos os grupos estavam desenhados presos a uma mesma corrente. De certo modo, a discriminação é apresentada como uma prisão, mas também como um elo que os prende a uma mesma situação, uma observação bastante sensível e perspicaz desses alunos.

Outro cartaz, feito por um grupo formado somente por meninas, chamou-nos também a atenção. Havia neste grupo duas alunas Pankararu. O cartaz não apresentava um trabalho em conjunto, mas foi feito como se fosse dividido em quatro quadrados, com cada aluna cuidando de sua parte. Em uma das partes, havia um texto que dizia o seguinte:

O negrinho

- Mãe, você mentiu para mim!

$-\mathrm{O}$ queêê?

- Você me disse que o meu irmãozinho era um negro?

- E é, meu filho. É um negro que o Senhor trouxe para a gente.

- É não. Eu joguei ele pela janela e ele nem voou.

O texto choca pela crueldade e por ser inadmissível do ponto de vista do respeito que se deva ter a todo e qualquer ser humano! Mas um detalhe que notamos 
posteriormente é que esta história havia sido copiada de uma outra fonte e que as alunas haviam substituído a palavra "anjinho" por "negrinho" e "anjo" por "negro". Ao lado, o seguinte texto da aluna Pankararu:

Hoje em dia o Brasil é um país que é bem trabalhado em história de racismo. Mas nós não entendemos porque nesse mundo a maioria das pessoas é discriminada por doenças, por cor e também tem o racismo e o preconceito. Eu sou contra tudo isso, sou contra a discriminação, sou contra o racismo e o preconceito. Se cada um fizer a sua parte, veremos uma grande diferença. Ass. G.

Em outra parte do cartaz, havia o desenho de uma mulher aparentemente negra e o seguinte texto: "Hoje muitas pessoas são discriminadas, índios, negros e etc. Quem sabe se isso pára. Nós iremos viver sem discriminação". Um fato curioso é que, no início da elaboração do cartaz, uma das alunas perguntou se poderia ser feito o desenho de uma indígena, mas, nesse ínterim, a figura foi vertida para a imagem de uma mulher negra. $\mathrm{O}$ fato de o grupo contar com duas alunas Pankararu provavelmente pode ter influenciado essa troca, fato que não pudemos averiguar com maior profundidade, mas que demonstra quão delicada era a questão da discriminação para os alunos.

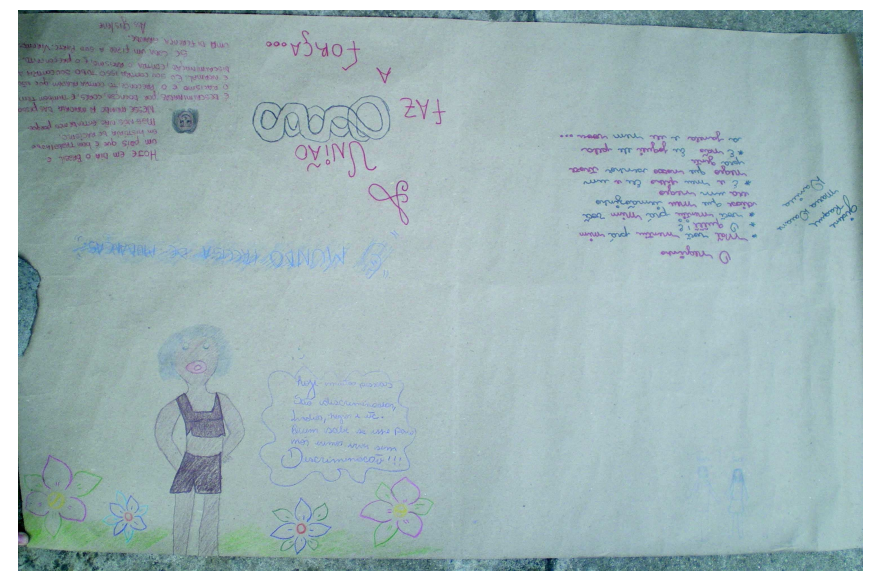

O cartaz, ainda que realizado de forma fragmentada, traz um libelo contundente e chocante contra a discriminação, mas também parece refletir um sentimento ambivalente que esse aspecto provoca nos próprios alunos.

Em reunião com a equipe depois dessa intervenção, observamos que seria importante que os grupos falassem um pouco mais sobre os trabalhos realizados, para que pudéssemos compreender com mais detalhes as mensagens que estavam buscando 
transmitir por meio dos cartazes. Desse modo, trouxemos na terceira intervenção os cartazes para que eles apresentassem no grupo maior. A atividade transcorreu muito bem, pois os grupos, de início, tímidos, foram expondo o sentido de seus trabalhos. A atividade, no entanto, chegou a um ponto crucial e nos levou à ferida que encontrava-se subjacente ao que presenciávamos nas intervenções. Em um determinado momento da intervenção, uma vez que o tema discriminação já estava sendo bastante abordado pelos alunos, alguns deles pediram a palavra e relataram uma situação que podemos resumir da seguinte forma: um dos alunos, que não pudemos identificar, ofendeu uma das professoras mais antigas da escola. Irritada com essa provocação, ela dirigiu-se à sala da $7^{\mathrm{a}} \mathrm{B}$ e começou a gritar com a sala, dizendo, entre outras coisas, que os alunos, na maior parte, moradores da favela do Real Parque, só vinham à escola para comer e não para estudar, atribuindo isso à má educação que os pais davam aos alunos.

A respeito disso, podemos recorrer a Vilhena (2006), que existe uma forma predominante de se olhar para a favela de maneira estigmatizada, como um lugar violento, perigoso e desorganizado, cujos moradores seriam mau-educados e aproveitadores, como bem demonstra a fala da professora. A favela apareceria então como um espaço, principalmente nas grandes cidades brasileiras, em que a estranheza na relação com o outro surge insistentemente. Assim, o estigma do morador da favela é a de ser alguém perigoso, estando isso presente mesmo em discursos que falam sobre o respeito à diferença, ao reconhecimento da singularidade e à busca de conhecer modos de vida diferentes. Assim, os moradores seriam vistos como:

Uma massa uniforme de um monstro subterrâneo prestes a destruir nosso mundo 'ordenado' e 'coerente'. Construímos, assim, uma realidade de uma única faceta, sem diferenças, nuances, ou contrastes. Ao morador de favelas não é permitida uma voz que seja diferente do que desejamos escutar; freqüentemente sua diferença é patologizada ou criminalizada. O "exótico" substitui o lúdico e a criatividade (Vilhena, 2006, s/p).

Esse comentário da professora atingiu profundamente os alunos e muitos deles se sentiram bastante feridos. Duas alunas, uma delas Pankararu, foram as mais incisivas, dizendo que este comentário da professora não era justo e que revelava uma grande discriminação por parte dos professores em relação a eles. Disseram ainda que não era porque os alunos viviam em uma comunidade pobre que vinham para escola 
somente para se alimentar. E que a família não devia ser colocada em questão, uma vez que a professora não conhecia a realidade vivida por eles.

Esse episódio, pelo que pudemos notar, surpreendeu e deixou atônita toda a equipe. No decorrer da discussão, o professor L. comentou que o aluno que havia feito o comentário portou-se mal, pela falta de educação com que tratara a professora, e que ela, por sua vez, também tinha se equivocado em reagir daquela maneira. Ele explicou que havia uma questão a ser pensada, que era a educação e o trato pessoal. A professora C. argumentou que os alunos deviam estimular os pais a virem nas reuniões para trazer essa questão para a escola. A professora P. também teceu comentários a respeito do que havia ocorrido, dizendo que tanto os alunos como os professores deviam se colocar no lugar um do outro. $\mathrm{Na}$ realidade, os argumentos colocados pelos professores demonstravam o intuito de apenas amenizar a difícil situação colocada pelos alunos e, de certo modo, buscavam proteger a professora que havia desrespeitado a sala.

Para contribuir para a discussão, escrevi na lousa a regra de ouro: "Não faça aos outros o que você não gostaria que fizessem a vocês mesmos". Perguntei, em seguida, como eles gostariam que os outros os tratassem, ao que responderam: "Com respeito, educação e alegria", além de outros pontos. Talvez em virtude do impacto que a reação dos alunos produziu na equipe, não pudemos, de fato, perceber o ponto nevrálgico da questão: a discriminação de classe por parte da professora. Isso porque o que estava ocorrendo não era uma relação de equidade e de reciprocidade entre uma professora de classe média e um aluno de 13 anos, pobre e morador de favela, mas sim uma total discrepância de situações sociais, uma vez que a discriminação que um indivíduo de classe média pode sofrer nunca será a mesma que a de um indivíduo que nasce em uma comunidade pobre e é objeto de discriminação desde a infância. De acordo com Amaral (2007), a grande questão aqui colocada é que não se tratava de uma situação entre iguais, uma vez que a professora estava ali não para competir com os alunos em um mesmo nível. Ela tinha, ao contrário, um papel a exercer junto a uma outra geração. Nenhum dos adultos presentes percebeu com clareza que estavam se colocando em situação de igualdade o que era discrepante, tanto do ponto de vista da diferença de gerações e, conseqüentemente, dos papéis de alunos e professores, quanto das situações vividas por distintas classes sociais. Não foi ponderado, por exemplo, que os alunos foram e são penalizados duplamente: ao serem responsabilizados pelas condições miseráveis em que vivem, ao mesmo tempo em que são discriminados por aquilo que eles não têm responsabilidade alguma. E, claro, responderam a esta situação relatada 
acima com indignação. No entanto, pudemos perceber que a primeira postura dos professores, em situações como essas, é a de proteger o professor (ou o mundo adulto) e não os alunos (o mundo da criança), e desse modo, abandonando o aluno ao seu próprio sofrimento. Enfim, são questões cuja complexidade apontava-nos a necessidade de um trabalho de conscientização, sobretudo junto aos professores.

Perguntamos aos alunos se desejavam continuar a discussão a respeito da discriminação na próxima intervenção e eles responderam que sim, demonstrando que este assunto estava ainda bastante vivo em seus corações. De certo modo, sentimos que uma ferida estava exposta entre os alunos e que não tínhamos conseguido chegar ao fundo da questão.

Em uma reunião posterior com a equipe, ao serem questionados a respeito de toda essa situação, os professores comentaram que já sabiam qual era a professora que havia feito tal comentário e confirmaram que se sentiram surpreendidos e tristes pelo que os alunos haviam comentado. Observaram também que havia uma questão ética envolvida em relação ao assunto, uma vez que a professora que havia feito aquele comentário era uma colega de trabalho há vários anos. Pode-se observar, desse modo, que os professores, além de se colocarem em uma postura corporativa, ainda se apegavam ao mito de uma escola e de um corpo docente neutro, que não reproduziria as discriminações sociais.

Segundo Giroux (1983), de acordo com uma perspectiva tradicional e instrumental do currículo, a escola é observada apenas como um mero espaço educativo neutro, ignorando qualquer concepção que a veja como um espaço cultural ou de embate entre grupos sociais e econômicos antagônicos. Ao ignorar as mediações de classe e de poder, as teorias tradicionais do currículo tratam a cultura como uma categoria neutra da ciência social ou como critério de padrão de excelência. O que está oculto nesse tipo de concepção é o fato de a cultura encontrar-se mediada pelo antagonismo de classes, que pressupõe desiguais oportunidades de acesso ao poder e ao conhecimento, bem como da capacidade de produzir, distribuir e legitimar seus bens culturais no contexto da sociedade.

Em realidade, isso nos levou a duas questões importantes: o conturbado e conhecido problema do relacionamento entre professores e alunos, agravado pelo fato de, muitas vezes, pertencerem a classes sociais diferentes; e a discriminação que, na realidade, não vem exatamente de fora da escola, mas da própria escola. A questão que 
se tornou evidente é que, de fato, a escola e seus agentes reproduzem a discriminação, o preconceito e os estereótipos que a própria sociedade tem imposto às classes populares.

\section{Racismo institucional e racismo estrutural}

Torna-se interessante então que compreendamos as definições de racismo institucional e racismo estrutural. De acordo com Segato (2006), no Brasil, assim como em outros países do continente latino-americano, o racismo emotivo e de "hábito" produzem o que chamamos de racismo institucional e racismo estrutural.

Podemos denominar de racismo estrutural a todos os fatores, valores e práticas que corroboram a reprodução da associação estatística significativa entre raça e classe (definida aqui como a combinação de situação econômica e inserção profissional), ou seja, seria tudo aquilo que contribui para se estabelecer pessoas não-brancas em posições sociais de menor prestígio e autoridade e em profissões menos remuneradas.

Agora podemos chamar de racismo institucional as práticas institucionais que conduzem à reprodução de desvantagens para a população não-branca. É um mecanismo de exclusão perfeitamente jurídico, mas nunca legítimo ou ético. Nesse caso, poderíamos colocar como exemplo a não-abordagem ou a abordagem equivocada da questão indígena e afro-brasileira nas escolas, o que contribui para o preconceito e a discriminação destes indivíduos dentro da escola ${ }^{81}$.

A compreensão e a utilização destes conceitos se tornam importantes para entender que o fenômeno do racismo em si e suas diferentes formas de manifestação variam, sendo possível assim identificar a discriminação racial em seus diferentes sentidos e formatos. Podemos observar também, por outro lado, que embora exista uma coincidência significativa entre raça/grupo étnico e classe social, as categorias de raça e etnia constituem um problema que deve ser distinguido de classe social para que seja possível a implantação de estratégias capazes de combater os preconceitos e as práticas racistas.

\footnotetext{
${ }^{81}$ Torna-se necessário gerar políticas públicas e normas que modifiquem todas as práticas institucionais que reproduzam a exclusão e promovam um tratamento diferenciado e positivo a setores historicamente prejudicados pelo racismo. Um outro exemplo de política pública foi a obrigatoriedade do ensino de culturas e histórias afro-brasileiras e indígenas nas escolas, promulgada recentemente no Brasil.
} 


\section{Reflexões do professor}

A intervenção revelou novos aspectos em relação à $7^{\mathrm{a}} \mathrm{B}$. Talvez já houvesse alguns indícios do que os alunos estavam buscando expressar, mas ainda não estavam evidentes para nós. Provavelmente a equipe não esperasse presenciar de forma tão escancarada os embates em sala de aula do ponto de vista daquele que se sente discriminado. Ao buscarmos instituir um espaço de discussão na escola, em que os alunos poderiam ter espaço para manifestar suas demandas e angústias, a equipe de pesquisadores pareceu não estar preparada para a intensidade do diálogo proposto e necessitaram de tempo para elaborar seus pensamentos e reflexões. Como bem coloca Giroux (1988), existe a necessidade de se considerar os professores não como meros funcionários técnicos, interessados apenas em aplicar e transmitir princípios científicos e objetivos, mas como intelectuais que pudessem promover uma escola que incentive os alunos a participar e lutar por esferas públicas democráticas. O professor L., em um momento posterior de reflexão, escreveu um relato da experiência da intervenção:

A última intervenção na Sétima $\mathrm{B}$, classe em que trabalhamos para introduzir a questão dos Pankararu, mostrou uma faceta dos alunos que até então estava escondida, por assim dizer. Antes, ao conversarmos e tentarmos um diálogo, notamos que a atitude era de cada um por si. Eles não estavam devidamente entrosados entre eles mesmos e não formavam uma equipe. E queriam se expor pouco. Nos desenhos, mesmo, cada um de um lado do papel, e ainda assim, ou limitados, ou não querendo dizer o que exatamente pensam, acham, suas razões e problemas. De uma maneira geral, os professores que trabalham na série consideram-nos fechados, pouco interessados, sequer mesmo para contestar ou discutir crises e situações.

Pois na última intervenção abriu-se um leque.

Enquanto falávamos, deixando-os à vontade - com a classe lotada como nunca com a entrada de alunos novos - pedimos que eles falassem e comentassem a respeito de seus trabalhos (desenhos e textos que fizeram em intervenções anteriores). Eles se levantaram em grupos e alguns deles comentaram a respeito do racismo, discriminação, preconceito, etc. Comentaram que são discriminados por moraram na comunidade (gostam mais de usar Comunidade do que Favela) e foi nesse sentido que o diálogo se estabeleceu e se desenvolveu afinal... O que foi para nós uma grande surpresa. 
Quando focamos de uma maneira geral e mesmo "en passant" a questão do aluno e do professor, segundo a perspectiva da autoridade em classe, eis que surgiu o problema: - Eles se sentem discriminados. Para dizer o mínimo.

Em uma situação difícil, de questão de foro íntimo e ética profissional com relação a um colega de profissão, tentamos conciliar, sem permitir que citassem nomes; tentamos esclarecer que professor é como eles, alunos, tem dia que está de mau humor, tem dia de trabalho sofrível, tem ações e reações, mas também lhes dissemos que teriam o direito de falar diretamente e com educação com os professores, mesmo fora da sala de aula. Neste momento, eles denunciaram a discriminação sofrida em diversas outras situações pelo fato de morarem em favelas e serem pobres, demonstrando assim a razão pela qual a sala é considerada "fechada" e se expõe pouco, talvez por entre outros tantos motivos (como a própria falta de professores como também ocorrera naquele dia), de se sentirem menosprezados (foi isso o que captei), de se sentirem maltratados de alguma forma pelos professores, alguns deles pelo menos, e até mesmo pelo sistema de ensino, escola e direção, etc. Considerando que foi uma das melhores classes onde intervimos, fica a questão: como exercer autoridade sem autoritarismo?

Além disso, em qualquer situação, o educador deve ser justo, ponderado, atento aos seus próprios preconceitos, para, desse modo, não punir um aluno com discriminação. Tampouco deixar agredir a classe inteira, ou falar abstratamente sem se referir ao caso em questão, muito menos o professor deve dizer que eles só vêm pra escola para comer mesmo, que nunca serão nada na vida, que não querem nada... e foi por aí o leque de "agressões" aos alunos... Triste, uma vez que os predestinam para o fracasso!

Os alunos demonstraram estarem feridos em seus brios. Tentaram essa porta aberta conosco para um desabafo e restabelecer um diálogo. Fica a questão: deveríamos tratar numa das próximas intervenções sob o enfoque de "autoridade"? Estudamos a possibilidade (e até escrevi um texto a respeito) da Questão Pankararu na comunidade escolar. Mas, penso, preocupado, como entrarmos direto na questão indígena, sem darmos um retorno a eles, numa nova discussão, sobre o problema que vivenciaram na escola e que os incomoda no contexto sócio-escolar?

Fica a questão: - No trato com os alunos, qualquer resposta a uma eventual agressão por parte deles, a "resposta" deve ser ainda assim didática, educativa, humanizada, bom senso e acima de tudo, ética, porque, afinal, a melhor pedagogia é o exemplo. E não se pode esquecer que não se trata de uma relação 
de reciprocidade, pois está em questão uma relação entre duas gerações com papéis e funções distintas uma da outra!

No texto acima, podemos observar toda a reflexão e a sensibilidade deste professor a respeito do que observou e vivenciou na intervenção. Embora buscasse, em suas palavras, um caminho conciliador diante da situação colocada, teve um olhar atento para a discriminação que os alunos sofreram em diversas outras situações, como, pelo fato de morarem em favelas e serem pobres, e também o problema da falta de professores, além do menosprezo que sentem por parte do sistema de ensino em geral. Outra observação que chamou a atenção foi sua percepção de que não se poderia entrar na questão indígena nas intervenções, sem que fosse possível realizar uma nova discussão a respeito dos problemas que vivenciam na escola e que os incomoda no contexto sócio-escolar. Nesse comentário, é possível notar que a questão da inclusão dos indígenas na escola cinge-se de uma maior complexidade, pois devemos observar também o fato que a discriminação não é apenas étnica, mas também atinge todos os alunos da escola, uma vez que a eles estão situados "no quintal" de um bairro nobre de São Paulo. A discriminação sentida pelo fato de residirem em uma comunidade pobre é uma questão sensível entre os alunos, pois muitos demonstram que ela é sim sentida, e profundamente, inclusive dentro da própria escola. Podemos vislumbrar nestas reflexões as possibilidades que, nas intervenções, os professores assumam de fato o papel de intelectuais transformadores, como define Giroux (1983), capazes de proporcionar voz ativa aos alunos e permitir que se transformem em agentes sociais contextualizados em suas classes, culturas, desafios e expectativas de vida. Mas, para tanto, é necessário que o próprio professor entre em contato, como fez L., com seus próprios preconceitos e falta de visão social. Logicamente, torna-se necessário que o sistema educativo propicie de fato espaços para a formação destas esferas públicas para que haja uma maior proximidade do corpo docente e diretivo com as demandas e anseios dos alunos, além de proporcionar maior voz, autonomia e melhores condições básicas de trabalho para os professores. Cabe, evidentemente, ao professor o desejo e a possibilidade real, objetiva e subjetiva, de se transformar em um intelectual transformador ativo.

Em outro momento da intervenção, um dos professores perguntou quem dos alunos era Pankararu. A aluna G. levantou a mão, afirmando-se como Pankararu, com orgulho e sem medo, enquanto outros alunos indígenas não quiseram se identificar. Lembrando que foi esta aluna que denunciou, em alto e bom tom, a situação 
discriminatória que a sala vivenciou, em discussões posteriores com os professores, pudemos observar um agravante em relação aos alunos Pankararu na escola: parecianos pesar sobre esses estudantes, além da discriminação por serem indígenas, também o fato de experimentarem uma condição de pobreza e de morarem na favela, um local que gerava também outras formas de discriminações, criando impedimentos, inclusive para arranjar emprego.

Para Segato (2006), ao nos concentramos nas questões do racismo, cabe, por outro lado, verificar que os parâmetros para o estudo da identidade do afro-brasileiro e para a identidade do índio são diferenciados, passando a exigir conteúdos de etnicidade substantivos. Se no caso da questão dos afro-brasileiros, podemos falar de identidade racial, no caso do indígena, poderíamos falar de identidade étnica ou etnicidade. Muitos dos membros de povos indígenas, observados a partir de uma visão externa, podem ser percebidos como "negros", ou seja, descendentes de ancestrais africanos, porque esta ancestralidade se encontra presente nas características fenotípicas. Por outro lado, devido também à intensa miscigenação, uma grande porcentagem de indígenas brasileiros são índios negros, sem que isso necessariamente afete as classificações encontradas no interior do grupo indígena ou altere a representação que estes povos têm de si em nível nacional.

Estas questões, por outro lado, acrescentam alguns outros elementos a serem discutidos. No caso destes povos indígenas, pode recair sobre eles uma dupla discriminação - por terem características fenotípicas negras e/ou por possuírem uma identidade étnica indígena. Ou ainda por se questionar a existência de "índios" nas grandes cidades, considerando-se que a suspeição repousa na concepção do senso comum - antiga, superada e, no entanto, ainda bastante arraigada nos discursos atuais do índio como um indivíduo "primitivo" e "morador da selva", portanto incapaz ou "proibido" de residir nas cidades; ou pelo argumento de que um determinado indígena não porta um "fenótipo índio" e, portanto, não poderia se caracterizar como índio.

\section{Ferida aberta}

De certo modo, como pudemos observar na última intervenção, uma ferida estava aberta entre os alunos, provocada pela discriminação de uma professora em relação aos alunos. Uma ferida que não poderia ficar exposta sem que fizéssemos algo 
para tornar possível algum nível de elaboração. Por isso, decidimos passar um filme chamado "Vista a minha pele", sobre o qual tínhamos ouvido boas referências para tratar da questão. O filme mostra a inversão de papéis entre brancos (discriminados) e afro-brasileiros (discriminadores) em uma escola, buscando, por meio desse contraste, deixar mais claro como a discriminação de afro-brasileiros ocorre na sociedade e no meio escolar. As ações do filme se concentraram na disputa de uma menina afrobrasileira e outra branca pelo concurso de "Miss caipirinha" na escola. O título sempre havia ficado com a menina afro-brasileira. Ao assistir o filme, pude notar que o papel principal de discriminador havia ficado com uma atriz adolescente afro-brasileira, que agia de uma forma extremamente arrogante e discriminatória para com uma jovem branca, invertendo os papéis que historicamente têm se dado nos países onde ocorreu a escravidão, o que pôde produzir um efeito paradoxal nos que assistiam o filme, de modo a ressaltar, nesta inversão de papéis, a atitude discriminatória da sociedade.

No caminho à escola, coincidentemente encontrei a professora que havia provocado a celeuma entre os alunos no ponto de ônibus. Ela havia perdido a carona de uma colega e estava indo de ônibus, atrasada. Era uma professora já de idade, prestes a se aposentar, como ela mesma me disse no percurso. Foi interessante observar que ela não demonstrava ser a mesma pessoa que havia discriminado os alunos. $\mathrm{O}$ que pude notar é que havia um nítido contraste social entre essa professora, que vinha de um contexto de classe média alta, e os alunos que provinham de uma camada social desfavorecida. Fiquei refletindo sobre o fato que a discriminação parte, muitas vezes, de pessoas comuns, não necessariamente de pessoas que ficam apregoando a superioridade racial do branco em relação às outras pessoas, como fazem os indivíduos que formam gangues com objetivos declaradamente discriminatórios.

Chegando à escola fui preparar a sala de vídeo para receber os alunos. Com o término da aula anterior, eles foram chegando e se acomodando, cada um em seus grupinhos. A maior parte se sentou nas mesas do fundo da sala. Expliquei aos alunos a razão de passarmos o filme, que tratava da questão da discriminação. No entanto, antes de passarmos o vídeo, uma aluna Pankararu se levantou e disse que um aluno da classe havia sido ofendido com a alcunha de "pretinho" pela mesma professora que havia causado a celeuma anteriormente citada. Isso causou agitação dos alunos, que confirmavam com veemência o episódio que a aluna havia comentado. Uma das professoras tentou intervir, perguntando, de forma agressiva, ao aluno se ele havia se sentido discriminado. $\mathrm{O}$ aluno respondeu timidamente que não, mas ficou a impressão 
de que ele disse isso um pouco acuado pelas circunstâncias. Então, ela comentou com a sala que o importante era o fato de o aluno se sentir discriminado ou não e que os próprios colegas deveriam aprender a se defender. Outra professora comentou com a sala que ela era chamada de "branquinha", mas que não se sentia atingida por isso e que os alunos não deveriam se sentir atingidos Tivemos a impressão que a equipe, em geral, não estava preparada para lidar com a discriminação presente na escola, tratando a questão como se ela estivesse restrita a um plano pessoal. Novamente, pudemos observar uma atitude corporativa, visando mais a proteção do professor do que do aluno discriminado. Posteriormente refletimos que estávamos deixando de lado, em nossas abordagens, o grande ônus histórico que pesava, durante séculos, sobre o afro-brasileiro, o indígena e as classes desfavorecidas em geral e que a questão não era simplesmente de cor de pele, mas também envolvia todo um histórico de opressão social e cultural.

Começamos então a passar o vídeo, cuja apresentação foi dificultada em razão do baixo volume, o que gerou certa dispersão por parte dos alunos. Em um determinado momento do filme, uma das alunas repudiou a personagem afro-brasileira que discriminou a personagem branca, o que considerei um efeito contrário do que teria sido proposto no vídeo. Apesar de todos os contratempos, iniciamos uma discussão e pudemos notar que os alunos compreenderam bem a proposta do filme e o sentido da inversão dos papéis historicamente situada entre brancos e afro-brasileiros em nosso país.

\section{“Eu sou o que o outro não é”}

Um fato nos chamou a atenção na intervenção foi a confecção dos cartazes a respeito do tema: “O que é ser jovem?”. Uma das alunas pediu ajuda, pois o grupo não estava conseguindo realizar o trabalho por falta de idéias. Perguntei qual era a questão que os incomodava. Ela comentou, então, que os temas que enfrentavam eram o preconceito e a falta de respeito.

Perguntei a razão de ela falar de preconceito e ela apontou uma menina e disse que era discriminada pelo cabelo dela e por ser tímida. Pude observar que a menina tinha um cabelo trançado, estilo rastafári. A aluna com quem estava conversando comentou que, se isso ocorresse com ela, não responderia às brincadeiras e disse não concordar com as atitudes que os outros tomavam. Depois comentou sobre a falta de 
respeito que reinava na sala. Perguntei se era a falta de respeito dos professores em relação a eles, mas ela disse que era entre os próprios alunos. Pude perceber como, durante a conversa, a aluna e um menino do grupo ficavam provocando um ao outro com apelidos. Esse episódio nos chamou a atenção, pois aparentava mostrar uma provável conseqüência da discriminação que os alunos estavam sofrendo, reproduzindo tais atitudes e comportamentos entre eles mesmos. Em um determinado dia na escola, pudemos observar os alunos da $7^{\mathrm{a}} \mathrm{B}$ na quadra da escola e observamos algumas meninas dessa sala fazendo brincadeiras agressivas entre elas. Era comum que os alunos, durante as intervenções, fizessem brincadeiras jocosas uns com os outros. Em uma das intervenções, à medida que conversávamos com a classe, um dos alunos começou a brincar com outro, chamando-o de japonês. O menino não possuía exatamente uma feição oriental, mas ele comentou conosco que tinha ascendência indígena. Observando isso, levantamos uma questão, dizendo que eles mesmos poderiam estar discriminando uns aos outros em sala de aula. Esse comentário acabou por gerar uma série de provocações entre os alunos, principalmente entre os garotos, que utilizavam termos como "galinha preta" (em referência aos corintianos), "porco" (em referência aos palmeirenses) e "bambi" (em referência aos são-paulinos). Embora essas provocações pudessem parecer inofensivas, se pensarmos no contexto observado nas intervenções, elas não deixavam de revelar o quanto os alunos pareciam reproduzir os atos discriminatórios entre eles. Afinal, estes termos, de certo modo, refletem nas entrelinhas discriminações raciais e sexuais.

Pudemos observar nos depoimentos dos alunos que muitos deles, por se sentirem indefesos e incapazes de responder ao ofensor, acabavam por reproduzir a violência simbólica (Bourdieu, 1975) que recebiam entre seus pares na escola. Esse episódio nos faz presumir que, uma vez que a grande maioria dos alunos era de origem "humilde" (termo utilizado por eles para se referirem às suas condições precárias de vida) e estavam se sentindo discriminados, não estaria havendo uma reprodução da discriminação entre eles mesmos. Pudemos notar nessas atitudes a necessidade em se estabelecer certas fronteiras entre eles - como se fosse necessário diferenciar o "outro" para que o indivíduo pudesse firmar uma identidade -, como numa frase desse tipo: "eu sou o que o outro não é”. Seria o que podemos qualificar como identidade constrastativa, como demonstrado por Cardoso de Oliveira (1976), mas que se dá no interior de uma sala de aula. No entanto, não podemos deixar de registrar que a afirmação de uma identidade se faz com base no denegrimento do "Outro". 
Tendo estas idéias como norteadoras, em uma das intervenções, havíamos programado duas atividades: que os alunos respondessem por escrito a uma pergunta feita a respeito do relacionamento intra-classe e desenhar auto-retratos ou falar de si mesmo por meio de redação. Para estimular essa produção, trouxemos uma pequena autobiografia de Patativa de Assaré e alguns auto-retratos de Van Gogh, Escher e Rockwell ${ }^{82}$ para estimulá-los a pensar a respeito de si mesmos. Então, de início, demos pequenos pedaços de papéis em brancos para que eles escrevessem. E levantamos a seguinte pergunta: "O que você gostaria que não fizessem a você na escola e o que gostaria que fizessem?”. A pergunta era justamente para compreender como eles gostariam de ser tratados pelos colegas, professores e a escola, ou mesmo o que estavam sentindo em relação a tudo na escola e também compreender qual era a imagem que possuíam a respeito de si mesmos, individualmente falando.

Pouco a pouco, os alunos foram entregando os papéis. Depois de todas as respostas terem sido entregues, iniciamos a leitura de alguns deles diante da classe, sem citar os nomes dos autores. Foi interessante observar que a maioria dos alunos respondeu que não gostaria de ser xingado em sala de aula e que houvesse mais respeito entre os colegas. Fomos lendo as respostas e comentando cada uma delas. Alguns alunos disseram que realmente havia muita falta de respeito entre eles próprios e os professores.

Ao realizar um balanço posterior da atividade, obtivemos 14 respostas das perguntas feitas na intervenção, o que proporciona um quadro razoavelmente amplo das perspectivas dos alunos a respeito dos relacionamentos em sala de aula. À pergunta " $O$ que você não gostaria que fizessem a você em sala de aula?", pudemos observar que cinco dos alunos responderam que não gostariam que os alunos falassem mal uns dos outros em sala de aula, enquanto três responderam que não gostariam que os tratassem com desrespeito, além de outras respostas como: "que não mexessem comigo", que “(não) me chamassem por apelido", que "não ficassem gozando da minha cara" e que “(não) ficassem provocando". Apenas três respostas tratavam de questões disciplinares específicas da sala de aula, como "não riscassem as carteiras da sala", "conversar quando o professor está falando ou passando lição" ou "tacando bolinha de papel" e

\footnotetext{
${ }^{82}$ Optamos pela autobiografia de Patativa de Assaré, por este ser um poeta popular nordestino, sendo possível fazer referência a origem de seus familiares em um auto-retrato pessoal. Além disso, utilizamos auto-retratos de Van Gogh, Escher e Rockwell para estimular os alunos a realizar desenhos que os autoretratassem.
} 
uma resposta teve como enfoque os professores, solicitando que eles não xingassem os alunos. Chamou-nos a atenção as seguintes respostas:

“(Não gostaria que) me xingassem ou me deixassem com a moral lá embaixo!”

"Não gostaria que os meus amigos me xingassem, mas eu não ligo. Mas se eles ficassem me zoando, eu não vou ligar."

Podemos observar, por essas respostas, como a questão da ofensa atinge profundamente os alunos e, por aparecer freqüentemente nas respostas, não pode ser menosprezada. Já na pergunta "O que você gostaria que fizessem a você na sala de aula?", o quadro não se alterou muito, pois quatro alunos responderam que gostariam que os alunos respeitassem uns aos outros, incluindo os professores, enquanto as outras respostas mencionavam o desejo de mais discrição na atitude dos alunos em sala de aula. Uma das respostas sugeriu que os professores interagissem mais com os alunos. As respostas que mais me chamaram a atenção foram as seguintes:

"Colaborassem quando os professores pedissem atenção. Acho que respeitar não dói, né!";

“E gostaria que nós ficássemos só na paz, sorridentes, 'e boa', 'só na miúda', assim ficaria bom demais"

As respostas dos alunos demonstraram que eles estavam particularmente sensíveis aos relacionamentos intraclasse, ou seja, entre os próprios colegas, em especial no tocante ao desrespeito, às provocações, ofensas e uso de apelidos entre eles. Isso nos levou a pensar em que medida o preconceito e a discriminação que recorrentemente aparecem como denunciados nas intervenções e nos cartazes não estariam sendo interiorizados pelos próprios alunos, a ponto de eles reproduzirem os sentimentos e atitudes correspondentes entre eles mesmos. Perguntamo-nos se não seria uma forma de defesa ou uma "violência defensiva", que é a contrapartida de uma situação de violência vivida passivamente, que ataca sua integridade narcísica, quando sentida como ameaça à autonomia e ao pensamento do sujeito (cf. Jeammet, 2005)?

Nesse sentido, consideramos importante trazer uma reflexão que Vilhena (2006) estabelece a respeito da intolerância, tomando como base os pressupostos psicanalíticos de Sigmund Freud. De acordo com a pesquisadora, Freud demonstra que, nos grupos 
humanos, há sempre a necessidade da formação de pequenos círculos para estabelecer como inimigos quem estivesse fora deles, sendo este uma forma de solução para a pulsão de destruição. Assim, a lógica do traço identificatório diferencial regeria a aversão que se produz entre comunidades próximas ou que possuíam alguma forma de relação uma com as outras. Seria o que Freud denominaria de "narcisismo das pequenas diferenças", em sua obra O mal estar na civilização (1930 [1929]). Prosseguindo nestes pressupostos, Freud, na obra Moises e o monoteísmo [1939], ao refletir a respeito do anti-semitismo, argumenta que o fenômeno da intolerância acaba por surgir muito mais no tocante às chamadas pequenas diferenças do que em divergências fundamentais, ou seja, seria o que podemos chamar de ódio ao "quase semelhante". Neste caso, o ódio encontra seu objeto precisamente no campo do próximo, do semelhante. Chnaiderman (Apud Vilhena, 2006) afirma que a questão principal do racismo não é exatamente o medo do diferente, mas sim o medo do "igual". Nesse caso, poderíamos compreender o igual não apenas como aquele que, psicanaliticamente falando, nos remete aos nossos próprios horrores, mas também, se pensarmos em termos sociais e políticos, aquele que compartilha dos mesmos direitos que nós, conseqüentemente, partilhamos do mesmo poder e, portanto, compete conosco.

O fato de ter havido uma chacota com um dos alunos que possuía ascendência indígena nos fez refletir se a discriminação, velada ou não, por parte da escola ou dos próprios alunos não estaria fazendo com que os alunos Pankararu não se sentissem estimulados a se declarar indígenas. Com certeza, esta é uma questão que envolve não somente a relação aluno-professor e aluno-aluno, mas também toda uma cultura escolar que não valoriza as culturas minoritárias ou que sustenta uma visão do indígena como se ele fizesse parte da história do país, apenas remotamente, e não como um indivíduo que estaria presente na contemporaneidade, ainda atuante e buscando seus direitos. Uma questão que fica é como os alunos Pankararu estariam constituindo sua identidade sócio-cultural e psíquica em meio a um contexto tão complexo.

\section{Um coração sangrando}

As explicações para uma dificuldade por parte dos alunos Pankararu de se autoidentificarem etnicamente como indígenas mostraram-se bastante complexas, mas podem ser atribuídas, de acordo com as falas de alguns alunos Pankararu, à 
discriminação exercida sobre os indígenas, tanto por parte dos alunos como do próprio corpo docente. Pode se destacar também a visão etnocêntrica que reinou (ou reina) durante várias décadas na escola em relação aos indígenas (e também aos afrobrasileiros), visão esta carregada de estereótipos, de cunho passadista (vinculada exclusivamente ao passado sem que se faça uma mediação com o contexto atual, em que os indígenas lutam por seus direitos em diversas instâncias e localidades no país), mas que exerce uma fortíssima influência na maneira pela qual alunos e professores compreendem a questão indígena.

Além disso, outro tipo de racismo, ainda não devidamente classificado, tem se manifestado na EMEF Alcântara e na comunidade do Real Parque. Na tentativa dos indígenas buscarem fazer valer os seus direitos ou sua auto-identificação - seja nos ambientes urbanos, seja nas escolas - também são gerados diversos tipos de preconceito e discriminação, quando são desqualificados ou lhes é negada a condição de indígenas e, mesmo que haja algum reconhecimento, isso acaba por não se traduzir na efetivação dos direitos adquiridos. Vemos isso claramente no depoimento de M.D., quando lhe foi solicitada uma definição de discriminação:

"Quando você 'tira' alguém ou discrimina uma colega porque ela era descendente de indígenas. Perguntaram por que você veio para cá, quem te chamou, então se você é, fala o idioma do índio" (M.D.).

Um exemplo bastante evidente de desqualificação da condição de indígena por parte da sociedade pode ser visto no próprio bairro Real Parque. Pelo fato de os indígenas Pankararu terem um atendimento diferenciado no tocante a serviços de saúde ou acesso a universidades, isso faz com que eles sejam discriminados na própria comunidade em que vivem e na escola em que estudam, principalmente em razão de as pessoas não compreenderem a natureza compensatória dessa assistência diferenciada. Por fim, ao se negar a auto-identificação como critério de reconhecimento, os órgãos públicos e os não-indígenas acabam por negar aos indígenas os seus próprios direitos adquiridos. A título de exemplo de como este preconceito pode se efetivar na escola, em uma entrevista realizada com um dos professores de História da EMEF Alcântara. Perguntou-se a esta professora se ela considerava os índios presentes na cidade efetivamente como indígenas. A sua resposta foi não, pois ela considerava que indígena era apenas aquele que estava na aldeia, no contato com a natureza, e que, a partir do 
momento, que entrava em contato com a cidade, ele perdia a sua condição de indígena. Em um diálogo que teve com um aluno que freqüentava aulas no EJA, que anteriormente não afirmava ser Pankararu, mas que, a partir da possibilidade de poder adquirir uma bolsa de estudo em razão da afirmação de sua etnicidade, passou a se declarar sua identidade indígena, essa professora considerou este ato como uma prova de "corrupção" sofrida por este aluno. Admitiu ainda que a sua visão a respeito destas questões era bastante influenciada por Rousseau, que preconiza a representação de um indígena "puro" e "imaculado". A professora não refletiu, no entanto, sobre as condições sociais e culturais precárias às quais os indígenas foram historicamente conduzidos pela política indigenista e pela sociedade nacional e as discriminações que sofreram durante séculos, tornando-se obstáculos importantes para se auto-afirmarem como indígenas. O pensamento dessa professora reflete, em grande parte, a opinião da maioria dos professores, ainda influenciados por uma visão evolucionista da história, que já vem sendo contestada por estudos antropológicos recentes. E é neste ambiente adverso que muitos dos alunos indígenas na EMEF Alcântara vivem, o que lhes dificulta seriamente qualquer tentativa ou desejo de se auto-identificarem como indígenas.

Além da questão da afirmação da identidade étnica, não podemos esquecer que os jovens alunos Pankararu também se deparam com as questões pertinentes à fase conflituosa da adolescência, como a sexualidade e as questões identitárias, como pudemos observar nas diversas pesquisas e intervenções realizadas em sala de aula. Podemos então visualizar o quadro complexo em que os jovens Pankararu encontramse inseridos.

A aluna M.D. chamou-nos novamente a atenção. Ela era Pankararu, embora se recusasse a se identificar em público como tal. Nas primeiras intervenções, ela não quis participar das atividades, mas, depois, com a insistência de um dos professores, inseriuse em um dos grupos e passou a contribuir bastante no trabalho. Os professores, em reuniões posteriores, disseram ter se surpreendido com a sua participação. O professor L. comentou que chegou a tocar em seu braço num gesto de incentivo, mas a atitude dela foi de "limpar" o local em que ele a tocou.

Em outro momento, aproximei-me do grupo que ela participava, para observar as atividades que se desenvolviam. Nesse grupo, estavam M.D. e outra aluna Pankararu - G. Estas alunas, no entanto, pediram-me que eu saísse de perto, deixando explícito o repúdio ao contato com o mundo adulto. Depois que me afastei, elas comemoraram, 
dando a impressão de que a presença de um adulto as fazia sentir invadidas e quando conseguiram manter o controle desta distância com o outro, o sentimento parecia ser de triunfo.

Outra situação peculiar é que Maíra (pesquisadora do projeto) teve contato com M.D. no intervalo das aulas, antes de uma das intervenções. Maíra encontrou-a no pátio da escola, iniciaram uma amizade e passaram a trocar e-mails. Maíra havia combinado com M.D. de encontrá-la e ela trouxe fotos da participação de seu irmão no ritual Menino do Rancho, na Terra Indígena Pankararu no Brejo dos Padres. Surpreendeu-nos como, fora da classe, ao estabelecer uma relação de confiança com um adulto, como essa mesma garota que havia se recusado a se identificar como Pankararu, fazia questão de demonstrar sua identidade e origem indígenas a ponto de trazer fotos tirados por ela de um ritual do qual seu próprio irmão participou, colocando-se em uma situação conflitante e ambivalente em relação à sua ascendência indígena. Segundo Jeammet (2005), os problemas que eclodem na chamada crise da adolescência podem ser analisados sob o ângulo da expressão de uma divisão do próprio sujeito, que é conduzido a rejeitar uma parte dele mesmo, vivido como uma alienação possível em relação aos objetos de investimento, enquanto esta conduta de rejeição contribui para lhe permitir se afirmar em uma identidade negativa que não deverá nada ao objeto. "O sujeito esconde na sua negação sua inveja" (Jeammet, 2005, pág. 76).

M.D. estabeleceu uma relação de muita confiança e grande abertura com Maíra, a ponto de ela abrir-se a respeito de várias dificuldades que estava atravessando como adolescente e no seu relacionamento com a mãe. Situações muito graves, por sinal, a ponto de a mãe querer interná-la num orfanato. As razões disso foram esclarecidas posteriormente e eram mais complexas do que imaginamos. Envolvia o relacionamento de M.D. com o padrasto e os ciúmes da mãe em relação à filha. Além disso, M.D. volta e meia ela falava em suicídio. Comentou, ainda, a respeito de uma relação que teve com um traficante da comunidade, que resultou, em seu relato, em uma gravidez indesejada, embora depois tenhamos visto que isso não era verdade.

O que era evidente é que M.D. buscava desesperadamente se ancorar em algo (alguém), para que não fosse ao fundo do poço, pois precisava de uma escuta atenta como a que foi dada por Maíra, não sendo suficiente o trabalho que oferecíamos em nossas intervenções coletivas em sala de aula.

Foi interessante notar que, embora ela demonstrasse ter uma relação de desconfiança conosco, em outras ocasiões, pareceu buscar uma aproximação. Isso nos 
fez refletir sobre os estudos de Phillipe Jeammet, em que o autor argumenta a respeito da situação paradoxal da relação adolescente-adulto. Enquanto o jovem necessita se relacionar objetalmente com o adulto, ele também sente esta relação como ameaçadora, sobretudo pelo fato do pesquisador em questão ser homem. Esse paradoxo era evidente em M.D. Isso nos fez observar a complexidade da situação dos jovens Pankararu. Em uma situação familiar e social tão complexa como a vivida por esta jovem, nos questionamos como ela estaria construindo sua identidade psíquica e étnica. Na realidade, além da dimensão étnica, estava em jogo sua identidade feminina e familiar. É preciso observar que a mãe Pankararu de M.D. vive com o padrasto dela, nãoPankararu. Todos esses conflitos poderiam estar lhe causando grande sofrimento, como se pode deduzir de um auto-retrato que ela fez de si própria: um coração trincado com um prego (ou uma espada) encharcada de sangue.

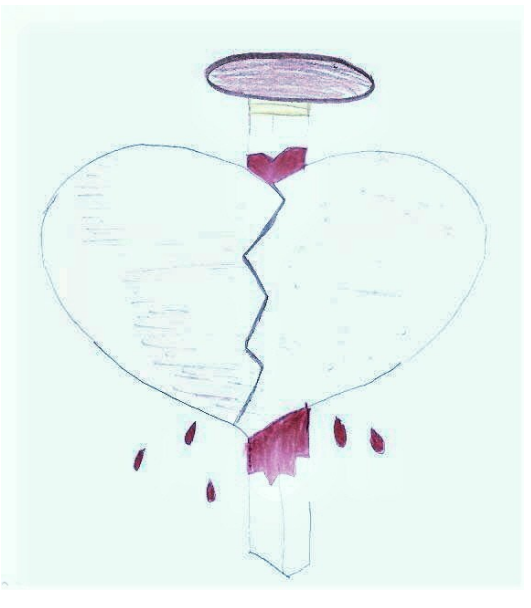

O conflito pelo qual a adolescente passava poderia estar representado simbolicamente pelo desenho deste coração atravessado. Isso nos chamou a atenção, pois poderia remeter ao que o psicanalista Phillipe Jeammet (2005) teoriza a respeito do adolescente. Segundo esse autor, a construção da personalidade se vê pautada por um paradoxo:

- para ser si mesmo, é necessário se alimentar dos objetos;

- ao mesmo tempo, é preciso se diferenciar deles e, para tanto, deles se afastar.

Identifica-se aí uma contradição em potencial na adolescência. O indivíduo, ao viver a imposição do desenvolvimento, sente isso como algo inelutável, cujo paradoxo (anunciado acima) necessita ser pensado ou mentapensado para o adolescente, uma vez 
que, para o jovem, é mais fácil controlar a distância dos objetos externos do que o desejo em relação aos objetos interiorizados. Uma atitude de oposição proporciona um recurso mais facilmente negociável entre o desejo de aproximação e a necessidade de diferenciação do que a consciência de uma relação de ambivalência. Segundo Jeammet, "opondo-se, o adolescente apóia-se sobre o adulto ao qual ele se confronta, sem ter que tomar consciência deste apoio e arranjando seu narcisismo e sua autonomia por meio da afirmação de sua diferença" (Jeammet, 2005, pág. 74). Neste tipo de relação, a busca do limite prevalece sobre a mudança, a aparência sobre a interioridade. O contato que é privilegiado: a ruptura é o exemplo do modo como é possível o adolescente se aproximar diferenciando-se e marcando os limites.

A atitude de "limpar a pele" demonstra, então, uma atitude de oposição ao mundo dos adultos, sendo, portanto, um recurso mais negociável do que admitir a necessidade de aproximação em relação aos adultos e de se diferenciar deles. Condutas negativas, de oposição ao outro e de recusa do desejo pelo outro, são capazes de exercer um intenso efeito de fascinação sobre quem as pratica. Recusar a atender aspirações e necessidades permite manter uma tensão interna constante que é sempre possível de não satisfazer, mas que dá ao indivíduo o sentimento de existência. Ao recusar de antemão o que poderia religá-lo ao objeto, o adolescente assegura a si próprio o domínio da situação que pode fazer com que acredite que tenha autonomia e independência do vínculo, sem que se dê conta de sua alienação em um comportamento de recusa, que só pode se auto-alimentar, já que mantém aumentada ou intacta a necessidade que ele supunha ter ultrapassado.

Nesse sentido, situações nas quais os adolescentes expressam atitudes de recusa de contato com o mundo adulto ou em expressões como "não tô nem aí", tão direcionada aos professores, demonstram na realidade o desejo de que sejam ouvidos e apoiados. Assim, verificando os desafios de alunos, principalmente os Pankararu, que estão constituindo sua identidade étnica e psíquica em um ambiente tão adverso, tornase necessário que o corpo docente da EMEF Alcântara e o próprio mundo adulto tenham um olhar atento às demandas destes jovens. E que estejam dispostos a repensar seus próprios preconceitos, visões de mundo e ações, incluindo as de cunho pedagógico, para que seja possível criar um ambiente escolar menos marcado pelo preconceito e discriminação e mais aberto às necessidades dos jovens, tão menosprezados nesta escola. 


\section{Semana de Diversidade e Cultura}

Nossa pesquisa de campo culminou com a organização e posterior realização da "I Semana de Diversidade e Cultura", evento realizado nos dias 3 a 8 de novembro de 2008, na EMEF Alcântara. Consideramos este evento como um desfecho fundamental do trabalho de pesquisa que realizamos na escola em relação aos indígenas Pankararu. Foi um momento único pelo fato de ter sido uma iniciativa da própria comunidade Pankararu que, deste modo, inseriu a temática indígena em uma escola pública nãoindígena na cidade de São Paulo. Além disso, por se tratar de uma pesquisa-ação, representou um esforço coletivo de intervenção na escola, envolvendo a comunidade Pankararu do Real Parque, nós, mestrandos e doutorandos (USP e UFSC), o corpo diretivo, professores e funcionários da EMEF. As conseqüências deste trabalho não puderam ser ainda devidamente avaliadas, mas podemos considerá-lo, independente de qualquer resultado, um grande passo e um possível caminho para qualquer tentativa de inclusão da temática indígena nas escolas. Além disso, os acontecimentos da Semana trouxeram elementos para conclusões a respeito de todo o trabalho realizado em relação aos Pankararu.

\section{O ponto de partida}

Tudo começou no dia 7 de junho de 2008, quando houve uma festividade dos indígenas Pankararu na EMEF Alcântara. $\mathrm{O}$ evento, que ocorria anualmente em abril ${ }^{83}$ na quadra esportiva do Projeto Casulo, foi realizado no mês de junho na escola devido a problemas de calendário. Semanas antes, havia cartazes afixados na EMEF Alcântara convidando a comunidade escolar a participar da festividade e alguns dos professores me avisaram que ela iria ocorrer na escola. Neste dia, dirigi-me à escola para participar e registrar o evento, uma prática constante em minhas pesquisas junto à comunidade Pankararu. Chegando à escola logo de manhã, fui recebido pelo Sr. Bino, presidente da Associação S.O.S. Comunidade Indígena Pankararu e cantador de toré, e Dora, liderança Pankararu e organizadora do evento, que me apresentou ao Marcos Albuquerque, antropólogo que estava realizando um trabalho junto aos indígenas na cidade. Havia poucas pessoas no local, situação que se repetiu ao longo do dia, em contraste com outras festas Pankararu que presenciei nos anos anteriores, que estavam

\footnotetext{
${ }^{83}$ Em decorrência do Dia do Índio (19 de abril).
} 
repletas de pessoas da comunidade e de outras etnias indígenas de São Paulo ${ }^{84}$. Dora comentou que isso teria ocorrido devido ao pouco tempo de organização e à dificuldade de avisar todas as pessoas a tempo. O próprio deslocamento do evento do Projeto Casulo para a EMEF pode ter sido também uma das razões do esvaziamento do evento, o que não deixa de revelar as dificuldades que a comunidade indígena tem para organizar suas atividades, uma vez que não possui um espaço próprio. No entanto, chamou-me a atenção a escassa presença da comunidade escolar no evento, com exceção de alguns funcionários que ficaram responsáveis por oferecer a infra-estrutura da escola para as atividades. Nenhum professor ou coordenador pedagógico esteve presente, inclusive os que me avisaram a respeito do evento; a diretora compareceu somente à tarde. $\mathrm{O}$ evento poderia ter sido uma ótima oportunidade para que o corpo docente pudesse ter maior contato com a comunidade indígena à qual atende, o que não ocorreu, demonstrando o descaso por parte da escola em relação à comunidade.

Apesar de tudo, o evento, que terminou à tarde, foi uma grande oportunidade para presenciar e participar do Toré apresentado pelos Pankararu. No final do evento, houve também uma demonstração de sapateado e hip-hop por parte de membros da ONG Favela Atitude. Em um determinado momento da festividade, sob iniciativa da própria Dora, realizamos uma reunião entre os pesquisadores presentes (Edson e Marcos Albuquerque), a escola (a diretora M.) e a comunidade indígena (Dora), com o intuito de reunir forças para realizar uma atividade de inclusão da temática indígena na EMEF Alcântara, o que possibilitou posteriormente uma interlocução teórica e prática entre pesquisadores e membros da comunidade Pankararu que muito contribuiu para a organização e realização deste evento. Como a comunidade escolar entrava em recesso no meio do ano, um Grupo de Trabalho (Dora, Marcos e Edson) foi formado para traçar as linhas gerais de uma Semana Indígena Pankararu ${ }^{85}$. Pensou-se para a Semana algumas atividades permanentes, como a confecção de um livreto, um vídeo de apresentação dos indígenas Pankararu para a escola e banners explicativos a respeito dos indígenas Pankararu (um trabalho conjunto da comunidade Pankararu e pesquisadores), além de sessões de filmes variados a respeito dos indígenas. Nas atividades com os professores e comunidade, estavam previstos debates a respeito de: diversidade cultural, inclusão obrigatória da história indígena, temas transversais,

\footnotetext{
${ }^{84}$ Apenas uma família da etnia indígena Fulni-ô esteve presente no evento, com uma barraca de artesanato.

${ }^{85}$ Em virtude dos integrantes do Projeto Culturas Juvenis estarem comprometidos com a fase de encerramento e preparação de relatórios conclusivos e de propostas para um novo projeto, coube a este pesquisador, por parte da equipe do Projeto, concentrar os esforços para a concretização da Semana.
} 
questão do indígena na cidade e discussões sobre a questão do preconceito e discriminação. Para os alunos, estavam previstas diversas oficinas, como de artesanato, danças e hip-hop. O encerramento das atividades, no sábado, congregaria as diversas oficinas realizadas durante a semana, a apresentação dos indígenas Pankararu e atividades de hip-hop, grafite e dança de rua que seriam realizadas pela ONG Favela Atitude, entre outros ${ }^{86}$.

Com o fim do recesso escolar, realizou-se a primeira reunião do Grupo de Trabalho com a diretora M. e a coordenadora pedagógica B. para discutirmos as linhas gerais propostas. A diretora M. desejava que a Semana também abarcasse a questão afro-brasileira. A idéia foi aceita, mas com a condição de que o Grupo de Trabalho se concentrasse apenas na questão indígena ${ }^{87}$ e que a temática afro-brasileira devesse ficar a cargo do corpo docente da escola. Sugeri também que abordássemos algumas questões que estavam sendo trabalhadas junto aos alunos no Projeto Culturas Juvenis para um debate com a escola nesta mesma Semana.

Com as reuniões subseqüentes, foi sugerido que o nome do evento fosse "I Semana da Diversidade e Cultura", visando ser o primeiro de outros eventos que seriam realizados posteriormente na escola. Por conta das atividades planejadas, o evento foi programado para o mês de novembro, coincidindo, portanto, com o mês da Consciência Negra. Além disso, em complemento à Lei $10.639^{88}$, de 2003, que estabelecia a inclusão no currículo oficial da rede de ensino a obrigatoriedade da temática "História e Cultura Afro-Brasileira", havia sido promulgada, em março de 2008, a Lei $11.645^{89}$, que incluía também a temática indígena no currículo. Consideramos que a recém promulgação desta Lei se tornaria um mote interessante para discussões a respeito das culturas indígenas e afro-brasileiras na própria escola e poderia servir de chamariz para a participação dos interessados no evento.

Estas leis, por outro lado, merecem uma discussão. De início, torna-se interessante que observemos a opinião de uma professora indígena para ilustrar a questão:

\footnotetext{
${ }^{86}$ Reconhecemos, posteriormente, que as atividades programadas eram bastante ambiciosas para um grupo de trabalho tão restrito, mas felizmente uma grande porcentagem do que foi planejado foi concretizada.

${ }^{87}$ Apenas a questão indígena iria demandar muito trabalho do Grupo de Trabalho.

${ }^{88}$ A Lei coloca como conteúdo obrigatório no currículo escolar o estudo da história da África e dos africanos, a luta dos afro-brasileiros no Brasil, a cultura afro-brasileira e o afro-brasileiro na formação da sociedade nacional, bem como a contribuição do povo afro-brasileiro nas áreas social, econômica e política pertinentes à história do Brasil.

${ }^{89}$ Esta Lei mantém todos os dispositivos da Lei 10.639, mas inclui também a obrigatoriedade da temática indígena no currículo.
} 
Na verdade não era preciso que houvesse uma lei dizendo: você é obrigado agora a trabalhar sobre a cultura africana, sobre a cultura indígena... Que as escolas colocassem isso no seu currículo (...) É por isso que têm surgido vários movimentos sociais em relação a isso. (...). Não é para conquistar o espaço, é para ter mesmo seu espaço. (...) Ninguém quer roubar nada de ninguém, a gente só quer o que é nosso (Professora Pankararu Maria Josée ${ }^{90}$ )

A comunicação desta professora Pankararu levantou uma questão: por que foi necessário implantar uma lei que estabelecesse o ensino obrigatório de cultura e história indígena nas escolas? A resposta é óbvia: justamente pelo fato de a escola não abordar a história e cultura indígenas em seu currículo e, quando o faz, acaba reproduzindo e reforçando os diversos estereótipos existentes a respeito do indígena. De certo modo, a instituição da obrigatoriedade do ensino dessas disciplinas demonstra o fracasso das tentativas anteriores de inserir a temática indígena nas escolas - quando da introdução dos temas transversais, por exemplo - uma vez que foi necessária esta ação para que a "história dos vencidos" da sociedade brasileira (como dos indígenas e afro-brasileiros) pudesse ser estabelecida juridicamente nos currículos escolares. Observe-se que a pluralidade como tema transversal nem sequer foi discutida na EMEF Alcântara.

No entanto, mesmo a instituição de uma Lei de obrigatoriedade de ensino não tem garantido a inserção das temáticas indígenas e dos afro-descendentes nas escolas. Segundo informe do Governo Federal (2008), depois de cinco anos da promulgação da Lei 10.639/03, torna-se evidente o não-cumprimento da lei por parte das escolas públicas e privadas. Um dos grandes entraves para a plena efetivação das Leis nas escolas pode estar no fato de os professores não terem recebido capacitação específica para a abordagem das histórias e culturas indígenas e afro-brasileiras e, portanto, não conseguirem abordar estas histórias e culturas em sala de aula ${ }^{91}$ ou mesmo por não se interessarem pelo assunto. Isso pode ser decorrente também do fato de que a matriz do conhecimento dominante nas escolas brasileiras é essencialmente eurocêntrica, o que faz com que histórias e culturas que não estejam nesta órbita acabem por assumir uma marca de exotismo para professores e alunos. Cabe lembrar que, sem o devido preparo dos professores, uma abordagem equivocada destas temáticas pode gerar mais

\footnotetext{
${ }^{90}$ Depoimento presente no vídeo Educação Pankararu (2008), de Maira Ferreira.

${ }^{91}$ Uma informação do Governo Federal de que alocou recursos de R\$ 10 milhões para a capacitação de professores nos mostra a discrepância entre o discurso, a prática e a efetividade destas leis.
} 
segregação do que inclusão em sala de aula. Nesse sentido, consideramos interessante que as mesas temáticas estivessem voltadas para estes assuntos, buscando configurar uma espécie de discussão pública no seio da escola para que alunos, professores e comunidade pudessem debater de forma ampla os assuntos usualmente silenciados na escola.

\section{As mesas temáticas}

Desse modo, foram decididas as mesas temáticas ${ }^{92}$. Além da Mesa de Abertura ${ }^{93}$, discutiríamos temas, como: o "Ensino obrigatório de culturas e histórias afro-brasileiras e indígenas e pluralidade cultural"; "Cultura e história afro-brasileira"; "Cultura e história indígena" e "Preconceito e discriminação étnica, sexual e religiosa". Portanto, procuramos cobrir todas as questões que envolveriam a Lei 11.645/08. A escolha dos participantes da mesa temática seria definida de acordo com o grau de comprometimento com o tema abordado, que seria uma forma de dar voz aos próprios afro-brasileiros e indígenas que assim poderiam falar a respeito de suas elaborações e experiências. No entanto, observamos a dificuldade de se encontrar pessoas que estariam dispostas a assumir o citado protagonismo em suas comunicações ou contribuir com as discussões que seriam realizadas. As mesas sob o título "Cultura e história afrobrasileira" e "Cultura e história indígena" demoraram a ser formadas, refletindo as dificuldades dos membros dos próprios grupos étnicos de se posicionarem em relação às temáticas propostas. Contatos com diversas pessoas foram realizados para a composição dessas mesas, mas elas só foram efetivamente formadas um mês antes do evento.

Foi planejada também, no início de cada mesa temática, uma apresentação de uma manifestação cultural que tivesse alguma relação com o tema da mesa de discussão. Assim, foram programadas as apresentações de danças brasileiras (realizadas por alunas da própria EMEF Alcântara), uma de hip-hop (por um integrante da ONG Favela Atitude), uma de capoeira (realizada pelos alunos do Mestre Boca), uma indígena (realizada pela Comunidade Pankararu) e outra performance de artes marciais.

\footnotetext{
${ }^{92}$ Assim foram denominadas as mesas-redondas.

${ }^{93}$ Para a Mesa de Abertura, convidamos o Diretor regional e o supervisor de educação do DRE-Butantã com o claro intuito de que eles se posicionassem a respeito da Lei recentemente promulgada, além da Diretora da EMEF Alcântara e da Diretora da EMEI Pero Neto, a prof ${ }^{a}$. Mônica do Amaral, da FEUSP, para que ela expusesse todo o trabalho realizado no Projeto Culturas Juvenis na EMEF e também apresentasse o quadro da escola, além de Bino Pankararu, liderança da comunidade Pankararu no Real Parque, configurando com isso uma primeira oportunidade de uma pessoa representativa de a comunidade Pankararu expressar as condições dos indígenas em um ambiente mais amplo da escola.
} 
Com as mesas formadas, o passo seguinte foi a confecção do folder deste encontro (Anexo II). Em uma das reuniões, buscamos construir, em conjunto, um texto de apresentação da Semana. Houve uma polêmica na reunião para definir quais seriam os melhores termos para se referir à sua ancestralidade: por exemplo, entre "índio" e "indígena"; ou ainda entre as opções "negro", "afro-descendente" e "afro-brasileiro"44". Ficou claro que os próprios termos para a auto-definição étnica não eram consensuais nem entre os próprios representantes destes grupos. Desse modo, o texto ficou assim definido:

“A Associação SOS Comunidade Indígena Pankararu, a EMEF José de Alcântara Machado Filho e a Universidade de São Paulo convidam todos a participarem da I Semana da Diversidade e Cultura, que será realizada entre os dias 3 e 8 de novembro de 2008 na EMEF José de Alcântara Machado Filho. Tendo em vista a lei $11.465 / 08^{95}$, que estabelece a obrigatoriedade do ensino de cultura e história indígena e afro-brasileira (em complemento à Lei 10.639/03), esta Semana se propõe a criar um espaço de debate a respeito de uma melhor implementação desta Lei na realidade escolar, de modo a permitir que haja um ambiente propício para a conscientização da comunidade escolar e sociedade em geral a respeito da marginalização e discriminação aos quais estão submetidos afro-brasileiros e indígenas no Brasil, especialmente na cidade de São Paulo".

Foram também estabelecidos alguns objetivos para esta Semana:

“Objetivo geral:

- Abordar de forma prática e teórica a aplicabilidade da Lei do Ensino Obrigatório de Culturas e Histórias Indígenas e Afro-brasileiras na escola (11.465/08).

Objetivos específicos:

- Desmistificar a visão estereotipada que a sociedade - incluindo a comunidade escolar - tem a respeito dos indígenas e afro-brasileiros e combater assim o preconceito e a discriminação em relação a eles;

\footnotetext{
${ }^{94}$ Optou-se, nesta dissertação, utilizar o termo "afro-brasileiro", por ele estar sendo assim utilizado nas Leis de obrigatoriedade de ensino.

${ }^{95}$ A Lei, na realidade, era a 11.645/08, mas por erros do próprio Legislativo, foi registrada inicialmente como 11.465/08, fazendo com que acompanhássemos o mesmo equívoco no folder.
} 
- Discutir as diretrizes do projeto político-pedagógico a respeito dos indígenas e afro-brasileiros com a comunidade escolar;

- Possibilitar um ambiente na escola no qual os alunos tenham um espaço propício para conhecerem a história indígena e afro-brasileira, valorizando assim a diversidade cultural".

Pelo teor do texto, foram delimitados, em linhas gerais, os seguintes objetivos da Semana: que se criasse na escola, utilizando como mote a Lei 11.645/08, um espaço de discussões a respeito dos indígenas e afro-brasileiros, suas culturas e história, uma vez que eram marginalizados e discriminados na própria escola, e assim desmistificar quaisquer estereótipos relacionados a eles, além de propiciar um ambiente escolar em que pudessem ser valorizados e se autovalorizarem. Pode-se dizer que eram objetivos ambiciosos para uma Semana apenas, mas que poderia ser um passo inicial para isso. Buscamos ressaltar ainda que a iniciativa era da comunidade Pankararu, colocando-a como protagonista do evento logo no início do texto.

\section{Uma proposta intercultural}

Para a organização da Semana, tivemos a inclusão da professora O., que trabalhava na secretaria da EMEF Alcântara e tinha atuação no movimento afrobrasileiro. Em seus comentários nas reuniões, O. mostrou-se inicialmente reticente a respeito da efetividade da inclusão da temática afro-brasileira na escola. Ela relatou tentativas anteriores de inserir as discussões a respeito da temática afro-brasileira na escola, com palestras de uma especialista a respeito do tema, que redundaram em fracasso devido à resistência dos próprios professores da escola. Comentou inclusive que uma das professoras da EMEF Alcântara teria lhe dito que não entendia porque deveria ser dar tanta ênfase à cultura e história afro-brasileiras, pois os imigrantes italianos, por exemplo, também haviam sofrido quando de sua inserção na sociedade brasileira $^{96}$. Em vista disso, a professora O. declarou o desconforto que sentia em abordar a temática afro-brasileira na EMEF Alcântara.

De certo modo, as leis que estabelecem a obrigatoriedade do ensino de história e cultura de etnias minoritárias geram controvérsias. A questão que se coloca é se realmente ajudariam a diminuir o preconceito nas salas de aula ou podem aumentar

\footnotetext{
${ }^{96}$ Este comentário revela uma grande miopia, pois, a despeito do sofrimento dos imigrantes, não se pode comparar com a realidade histórica da escravidão no Brasil.
} 
ainda mais a segregação, ao destacar a cultura e história das etnias minoritárias de outros temas curriculares. Se uma professora atuante na causa afro-brasileira sentira o aludido incômodo em sua própria escola, o que dizer de jovens alunos (tanto indígenas como afro-brasileiros) que se encontravam ainda em processo de desenvolvimento psicossocial e eram discriminados ${ }^{97}$ na própria escola?

Nesse sentido, cabe aqui realizar uma discussão sobre a questão da interculturalidade. Segundo Candau:

A interculturalidade orienta processos que têm por base o reconhecimento do direito à diferença e a luta contra todas as formas de discriminação e desigualdade social. Tenta promover relações dialógicas e igualitárias entre pessoas e grupos que pertencem a universos culturais diferentes, trabalhando os conflitos inerentes a esta realidade. Não ignora as relações de poder presentes nas relações sociais e interpessoais. Reconhece e assume os conflitos procurando as estratégias mais adequadas pra enfrentá-los (Candau, 2003, p. 148).

Assim, segundo Candau (2003), a interculturalidade se propõe a enfatizar uma postura dialógica que se coloca além da esfera da tolerância, promovendo o intercâmbio entre sujeitos das diferentes culturas que estão presentes no ambiente escolar, do mesmo modo que recusa qualquer processo de categorização que negue a complexidade dessas identidades culturais, ao "folclorizá-las" ou estabelecê-las hierarquicamente. Por outro lado, a interculturalidade pode assumir uma perspectiva de transformação política e social, tal como proposto pela pedagogia crítica, ao dar destaque às questões culturais, concebendo as diferenças como construções sócio-históricas decorrentes das relações sociais e, desse modo, superando uma visão segundo a qual a diversidade é assumida como "natural". De acordo com Wieviorka (2003), a interculturalidade significa que os intercâmbios e diálogos entre as culturas podem ser desenvolvidos por meio do respeito mútuo, o que difere da proposta do multiculturalismo, que demonstra a visão de um Estado ou de instituições que asseguram "a partir de cima" o reconhecimento de culturas diferentes. Desse modo, para a Semana, uma proposta de um diálogo intercultural faria mais sentido do que uma mera discussão a respeito da diversidade cultural ou que fosse partidária do multiculturalismo.

\footnotetext{
97 A professora O., nessa reunião, não quis se prolongar sobre o assunto, ficando evidente como discussões acerca do preconceito vivido no cotidiano da escola a atingiam profundamente.
} 


\section{A organização da Semana}

Uma das questões que mais gerou discussões foi o dia de encerramento da Semana, que ocorreria no dia 8 de novembro ${ }^{98}$, com diversas atividades planejadas, como apresentações indígenas, oficinas para alunos, uma apresentação de Toré da etnia indígena Wassu, um coral infantil Guarani e, para finalizar o evento, teríamos o Toré Pankararu. No entanto, também neste dia estava programado o chamado Sábado Feliz, no qual professores e funcionários estariam entregando o leite para as famílias dos alunos $^{99}$, além de estar programada também uma série de outras atividades como um trabalho com o Projeto Aprendiz e também uma peça de teatro dos Doutores da Alegria. Apesar das controvérsias em razão das inúmeras atividades que seriam realizadas no sábado, acabou preponderando a opinião nas reuniões de que tudo isso viabilizaria, em termos de público, as próprias atividades propostas na semana. Além disso, como no sábado haveria uma reposição de aula dos professores, seria uma "garantia" da presença deles no evento.

Com o intuito de envolver os professores participantes do Projeto Culturas Juvenis na Semana, realizei uma reunião para que eles pudessem nos auxiliar no planejamento e no trabalho a ser realizado, principalmente no sábado do dia 8. Como estávamos praticamente no encerramento dos trabalhos do Projeto Culturas Juvenis, pude observar certa desmobilização dos professores participantes, que se tornou mais evidente nesta reunião. À medida que fui expondo as linhas gerais da Semana, pude observar certo ceticismo em relação ao evento que seria realizado, principalmente devido à participação direta da diretora da EMEF. Os professores protestaram em relação à carga de atividades que haveria no sábado do dia 8 de novembro. Expliquei a eles que a Semana poderia ser apenas efetivada neste período e qualquer adiamento ou antecipação tornaria inviável a sua realização. Sugeriram inclusive que a apresentação do Toré Pankararu fosse realizada na parte da manhã para que os professores pudessem acompanhar, pois muitos deles não estariam presentes à tarde. Na realidade, o propósito

\footnotetext{
${ }^{98}$ Em decorrência de problemas no calendário escolar, foi possível realizar a Semana apenas na semana de 3 a 8 de novembro.

${ }^{99}$ O Programa Leve Leite havia sido instituído inicialmente na gestão do prefeito Paulo Maluf em 1995. A despeito de sua função possível social (combater a desnutrição da população infantil e diminuir o índice de evasão escolar da Rede Municipal de Ensino), podemos considerar este programa antipedagógico, pois retira os professores de sua função de educador e desvirtua também os objetivos da escola, que se torna um espaço assistencial do Estado. A cada nova gestão da prefeitura, esta prática prossegue por motivos políticos (sua retirada poderia refletir negativamente na imagem da gestão vigente na prefeitura de São Paulo). Posteriormente, a diretora achou por bem não realizar a entrega do leite para a comunidade neste dia e sim, durante a semana, para evitar maiores confusões.
} 
do Toré ser realizado à tarde seria para encerrar ritualmente as atividades deste dia. No entanto, ficou evidente que a maioria dos professores estaria no sábado simplesmente para cumprir horário, deixando a entender que as atividades deveriam ser realizadas mais em benefício deles mesmos, do que visando o melhor para a comunidade.

Evidenciava-se assim a relação burocrática mantida pelos professores com qualquer atividade que estaria sendo promovida na escola. Não se pode negligenciar, nesta reunião tensa, a participação das relações de hostilidade dos professores para com a diretora que geraram uma desconfiança ainda maior em relação às intenções desta ao promover o evento. Os argumentos eram de que a diretora iria provavelmente deixar todo o trabalho na mão dos envolvidos, inclusive dos professores, e que não se mobilizaria efetivamente para a realização da Semana. Comentaram também que, em iniciativas anteriores por parte dos professores, sempre houve ações de boicote por parte da diretora para que as atividades não se realizassem a contento. Ao que tudo indicava, os professores estavam resistentes em tomar qualquer iniciativa que tivesse a participação da diretora. Nesse sentido, ponderei que o objetivo da Semana deveria ser, acima de tudo, beneficiar a comunidade escolar e melhorar a interação dela com a comunidade indígena e que isso deveria estar acima de qualquer hostilidade entre professores e diretoria, sustentando que esta relação conflituosa só estava trazendo prejuízos para a própria escola. Assim, devido à crescente desmobilização demonstrada pelos professores e também em razão da relação conflituosa destes com o próprio corpo diretivo, tornou-se praticamente inviável realizar um trabalho em conjunto consistente com os professores.

De qualquer modo, programamos uma reunião para que o antropólogo Marcos Albuquerque pudesse realizar um diálogo com os professores do Projeto a respeito da questão indígena. Isso só pôde ser realizado a muito custo em razão da dispersão dos professores. Nesta reunião, Marcos então exibiu um vídeo que elaborou juntamente com os indígenas Kapinawá do Nordeste, resultante de sua dissertação de mestrado, e promoveu uma discussão com os professores a respeito dos indígenas na cidade, seus direitos e suas condições. A explanação de Marcos trouxe maior compreensão aos professores da relação que o Estado e a população em geral mantém com os indígenas. A reunião, por outro lado, evidenciou o nível de desconhecimento dos professores a respeito da questão, sendo este um agravante em razão da escola justamente atender a uma comunidade indígena. Ficou claro que seria necessário um trabalho de formação prolongado e consistente para que o corpo docente da escola pudesse se conscientizar 
com mais propriedade a respeito deste assunto. Uma das professoras comentou posteriormente que havia a necessidade de que esta atividade pudesse ser realizada com o restante do corpo docente.

\section{Os preparativos}

À medida que a data da Semana se aproximava, foi ficando mais e mais evidente que a organização do evento estava restrita apenas ao Grupo de Trabalho e que o corpo diretivo e docente da EMEF Alcântara não estava se mobilizando efetivamente para a Semana. Nas reuniões com a diretora, pareceu-nos que o trabalho de mobilização dos professores e organização das atividades estava ficando a cargo somente do Grupo de Trabalho ${ }^{100}$. Por essa razão, decidimos restringir o número de oficinas a serem realizadas com os alunos, dando, assim, um claro recado à EMEF Alcântara de que era necessário que eles se mobilizassem, caso desejassem que as atividades com os alunos fossem realizadas. Além disso, a preparação dos professores para a Semana teve de ser adiada para uma data posterior, uma vez que não haveria tempo hábil e mesmo os professores ainda não haviam demonstrado um efetivo envolvimento nas propostas da Semana. Desse modo, concentramos nossos esforços no trabalho de organização e confecção dos materiais ${ }^{101}$ propostos para a Semana, que consistiria em um livreto ${ }^{102}$

\footnotetext{
${ }^{100}$ A diretora M. parecia demonstrar não ter autoridade suficiente para direcionar o trabalho com os professores e buscava, com isso, se pautar nas iniciativas do Grupo de Trabalho para o diálogo com os professores. Por outro lado, as iniciativas por parte deste pesquisador de inserir os professores na organização não tinham se realizado a contento.

${ }^{101}$ A partir de observações realizadas e materiais obtidos nas pesquisas, tornou-se consenso no grupo de trabalho que se tornava primordial que os materiais (livreto, vídeo e banners) deveriam ser elaborados no intuito de combater o estereótipo presente na escola a respeito dos indígenas em geral, principalmente em relação aos que estavam presentes na cidade.

${ }^{102} \mathrm{O}$ livreto Eu venho do mundo foi elaborado em uma linguagem simples e didática e teve como objetivos iniciais desmistificar a visão estereotipada que a sociedade - incluindo agentes escolares e alunos - tem a respeito dos indígenas e combater assim o preconceito e a discriminação em relação a eles, estabelecer diretrizes para um projeto pedagógico para a escola a respeito dos indígenas, construído com os próprios agentes escolares e alunos; e apresentar a história e cultura Pankararu e a trajetória deles para São Paulo. A estrutura do livreto estaria baseada em tópicos-perguntas que supúnhamos serem dúvidas correntes em relação aos indígenas para assim desmistificar as visões estereotipadas a respeito deles.
} 
(Anexo IV), um documentário em vídeo ${ }^{103}$ - ambos intitulados Eu venho do mundo ${ }^{104}$ - e banners explicativos ${ }^{105}$ (Anexo V).

\section{Os preparativos da Semana na escola}

Semanas antes do início do evento, o corpo diretivo e docente da EMEF Alcântara passou a se mobilizar para a realização de uma programação em sala de aula que envolvesse os alunos na Semana. Graças à atuação da coordenadora pedagógica B., fez-se todo um trabalho de conscientização de professores e alunos a respeito dos objetivos do evento. Desse modo, em meio às aulas costumeiras, todas as classes foram contempladas com atividades relativas à diversidade cultural em salas de leitura, com oficinas (pintura em tecido, bonecos de sucata e artesanato indígena ${ }^{106}$ ) e projeções de desenhos e filmes ${ }^{107}$. Além disso, foram programadas também apresentações de percussão, dança do ventre e dança de rua por parte dos alunos do Grêmio da EMEF Alcântara, rodas de capoeira e dinâmica a respeito de relações amorosas ${ }^{108}$ (Anexo III). Foi interessante que a maior parte destas atividades foi coordenada pelos próprios

${ }^{103} \mathrm{O}$ vídeo foi elaborado de certo modo como uma tentativa de tradução em imagens do conteúdo presente no livreto, buscando responder também às perguntas formuladas, tendo como material as filmagens que foram realizadas com as diversas etnias indígenas presentes na cidade de São Paulo em suas mobilizações em torno de seus direitos diferenciados, com especial enfoque nos indígenas Pankararu do Real Parque. Foram registrados os esforços destes indígenas em se organizarem politicamente em torno de associações, como uma forma de afirmarem a diferença e se constituírem como sujeitos políticos diante do Estado e assim requisitarem atenção e assistência por parte dos órgãos públicos para as suas diversas demandas. Também perpassa pelo vídeo a luta dos indígenas para se desvincularem dos estereótipos dos quais são vítimas, ao mesmo tempo em que se utilizam justamente das imagens que a sociedade envolvente lhes impõe como estratégia política de conquista de seus direitos. É nesse processo contraditório que os indígenas se colocam e se afirmam etnicamente diante da sociedade nacional. A realização do vídeo, que seria apresentado na Semana, seria uma forma de contrapor os indígenas na cidade apresentados no vídeo a um modelo único de um indígena "do passado" e "primitivo", apresentado nos livros didáticos adotados pela escola e reproduzido no ensino dos professores, bem como no trabalho dos alunos.

${ }^{104}$ O título "Eu venho do mundo", que dá nome ao livreto e ao vídeo, veio de um dos refrões de um toante cantado pelos Pankararu: "Mestre bonito, da onde vem?; Mestre bonito, da onde vem?; Eu venho do mundo; Do mundo eu venho; Eu venho do mundo; Do mundo eu venho".

${ }^{105}$ Estava programada também a confecção de banners que serviriam para ilustrar as condições sociais e as peculiaridades culturais dos indígenas Pankararu durante a Semana, mas que serviria para todos os eventos que eles realizassem posteriormente. Os banners deveriam ser auto-explicativos, compostos por fotografias que tiramos em diversas apresentações e também por frases coletadas em depoimentos dos próprios Pankararu. Dora teve uma participação importante em sua elaboração, auxiliando na escolha de textos e fotos que eram condizentes com a mensagem que os próprios indígenas gostariam de transmitir a um público mais amplo.

106 Leituras de histórias indígenas e artesanato indígena ficaram sob a responsabilidade de Dora Pankararu.

${ }^{107}$ O desenho "Kiriku e a Feiticeira II", e os filmes "Racionais MC", "Viva a Diferença" e "Das crianças Ikpeng para o mundo", este um documentário a respeito do modo de vida da etnia indígena Ikpeng, em Mato Grosso, utilizado para uma discussão com os alunos.

${ }^{108}$ Dinâmica realizada por Tatiana Karinya Rodrigues, pesquisadora do Projeto Culturas Juvenis. 
professores e alunos ${ }^{109}$ da EMEF Alcântara, possibilitando um grande envolvimento do corpo docente e discente nas atividades da Semana, demonstrando-se, assim, que havia espaço para que professores e alunos pudessem desprender-se do cotidiano convencional das aulas tradicionais e se beneficiar do contato e diálogo com as culturas indígenas, afro-brasileiras e juvenis, como proposto pelo Projeto Culturas Juvenis (cf. Amaral, 2006). As conseqüências dessa abertura, por parte da escola, poderiam ser um primeiro passo para que o corpo docente passasse a refletir a respeito de sua própria relação com o conhecimento e com a realidade sócio-cultural dos alunos.

\section{A realização da Semana}

Foi então que, nos dias 3 a 8 de novembro de 2008, a I Semana da Diversidade e Cultura foi realizada (Anexo VII). Cabe ressaltar que a Diretoria Regional de Educação do Butantã, da qual a EMEF Alcântara faz parte, não realizou nenhum esforço de divulgação do evento para as escolas que estavam sob sua jurisdição, em uma nítida demonstração de falta de interesse pelo que estava sendo realizado. Independentemente disso, os folders foram distribuídos nas escolas adjacentes ao Real Parque e também por Internet. Além disso, alguns sites e blogs também divulgaram o evento.

\section{A mesa de abertura}

A Semana foi aberta no dia 3, segunda-feira à noite, com a apresentação de Maracatu na quadra da escola por alunas da EMEF Alcântara. Em seguida, tivemos a exibição em telão do vídeo Eu venho do mundo para o público presente e logo depois a Mesa de Abertura foi composta. A única ausência registrada foi a do Diretor Regional de Educação, que foi representado pelo Supervisor de Educação ${ }^{110}$. De certa maneira, a Mesa de Abertura sintetizou muito dos problemas identificados naquela escola durante nossa pesquisa, como veremos a seguir.

A diretora M. da EMEF Alcântara abriu a mesa, mencionando a imensa satisfação que tinha em falar sobre a diversidade cultural, que por muito tempo havia sido ignorada na escola e que vinha ganhando destaque mais recentemente no discurso

\footnotetext{
${ }^{109}$ Cabe ressaltar a organização, pela primeira vez, do Grêmio da escola, formada por alunos da própria EMEF Alcântara e que apresentou suas danças para os próprios alunos.

${ }^{110}$ As comunicações dos integrantes das diversas mesas de discussões estão registradas em linhas gerais, para uma melhor objetividade do trabalho.
} 
escolar. Ressaltou a necessidade da prática do diálogo de maneira a valorizar as culturas, em suas singularidades, modos de sentir e de produzir saber, fazendo com que todas as diferentes expressões culturais pudessem conviver juntas no ambiente escolar.

A comunicação seguinte foi a do Supervisor de educação da Regional Butantã C., que destacou a luta dos indígenas Pankararu por seu reconhecimento, como havia sido destacado no vídeo. Ressaltou que a escola deve oferecer um ensino de qualidade e afirmou que a diversidade cultural deve ser garantida na escola. Sustentou, ainda, que a diversidade cultural na escola seria uma questão política de auto-afirmação das etnias presentes de modo a quebrar a hegemonia e subverter a lógica presente na cultura escolar.

A seguir, a professora Mônica Amaral, da FEUSP, iniciou sua comunicação expondo o trabalho realizado pelos pesquisadores e professores do Projeto Culturas Juvenis e dos desafios impostos pela própria escola ao andamento da pesquisa. A despeito das dificuldades e desafios encontrados, a pesquisa realizada junto aos alunos adolescentes trouxe uma história rica de cultura e tradições que não estavam sendo notadas pela própria escola. Ressaltou a realidade caótica vivida pela escola, com diversos alunos e classes sofrendo diante da ausência significativa de professores em sala de aula. Os alunos, por sua vez, eram obrigados a enfrentar diversos exames de avaliação de aprendizagem sem que houvesse uma contrapartida, em termos de qualidade de ensino e contratação de professores. Reafirmou a importância de se conhecer a história dos alunos e de suas famílias, de valorizar as diferentes culturas ali encontradas - em que se misturam a tradição, sobretudo nordestina, e as culturas urbanas juvenis - e repensar a escola e suas prioridades.

Foi dada então a palavra para o Sr. Bino, liderança Pankararu, que ressaltou a gratificação que estava sentindo pela realização da Semana, sobretudo por ser uma iniciativa da Associação presidida por ele, e que era provavelmente a primeira iniciativa nesse sentido realizada em uma unidade escolar (não-indígena). Relatou um pouco de sua trajetória e a da comunidade Pankararu do Real Parque. E destacou a necessidade de haver um tratamento diferenciado para os indígenas e afro-brasileiros, consideradas a história de lutas e opressão desses povos. Destacou o trabalho e a sinceridade com a qual as comunidades em geral estavam se mobilizando para fazer valer este tratamento diferenciado, que era garantido pela legislação, mas cuja efetivação, na prática, estava muito distante do almejado por eles. Comentou que, como resultado dessa mobilização, 
muitos parentes indígenas estariam se formando na Universidade e esperava que a USP também pudesse abrir espaço para os estudantes indígenas.

Por fim, a comunicação final coube a Diretora G., da EMEI Pero Neto, que declarou estar bastante feliz por participar de uma semana inter-étnica. E afirmou que a escola negava essas diferenças, partindo do princípio de que todos eram iguais. E que isso felizmente estava mudando. A história do afro-brasileiro na escola sempre foi negada e, em razão disso, os alunos não afirmavam sua negritude. Frisou a necessidade da mudança do currículo e que a Semana estava sendo o pontapé inicial para que os jovens afro-descendentes não tivessem mais vergonha de serem afro-brasileiros.

A coordenação da mesa estava a cargo de Dora Pankararu, que relatou também um pouco de sua trajetória e da comunidade Pankararu, finalizando os debates daquele primeiro dia. Na platéia, estavam alunos e professores da EMEF Alcântara, membros da comunidade Pankararu e de outras etnias indígenas, além de alguns estudantes da Universidade, mas não notamos a presença de professores de outras unidades escolares. Pareceu-nos uma indicação, de certa forma, do desinteresse das escolas e de seus professores em geral pela temática. Nas comunicações das mesas, ficou evidente a discrepância entre o discurso da Diretoria Regional de Educação e a prática vivida pela escola, o que foi acentuado pela ausência do Diretor Regional de Educação no evento e de qualquer tipo de apoio ou divulgação por parte do órgão. Tudo isso demonstrava o descaso com que as secretarias de educação tratavam da questão da diversidade cultural na escola. De outro lado, diante de tantas resistências, ficavam claras as dificuldades do Estado de dar atenção à questão das etnias minoritárias na área educacional.

Segundo Oliveira Filho (1999), o Estado Nação, calcado em um modelo iluminista de organização, estabeleceu uma rede coletiva de relações entre os indivíduos que se faz apoiada por práticas de homogeneização cultural e de re-elaboração simbólica, de modo que determinados valores e crenças passam a ser partilhados pelos membros desta coletividade. A escola, de um modo geral, se torna a instituição onde este modo de pensar acaba se cristalizando nas mentalidades, incluindo professores, e sendo transmitido por todos e a todos. Para o pensamento iluminista, os vínculos particularísticos entre indivíduos - como os de pertencimento étnico ou racial, por exemplo - se tornam obstáculos para o desenvolvimento e fortalecimento das instituições do Estado, de modo que toda espécie de agrupamento étnico que mantenha apego a tradições locais e étnicas e que não esteja em conformidade com a nacionalidade dominante passa a ser visto como um entrave para o pleno 
desenvolvimento do modelo e, portanto, passível de desestímulo ou até mesmo de supressão. Assim fica evidente a nítida tensão entre, de um lado, a atenção à diversidade cultural e o respeito à diferença, garantido pelos textos jurídicos e recomendações governamentais federais, e, de outro, a resistência e os obstáculos para a compreensão e aceitação desse direito à diferença pelas instâncias burocráticas responsáveis pela implementação das políticas adotadas por esses órgãos (Secretarias Estaduais e Municipais de Educação, Conselhos Estaduais de Educação, entre outros).

No entanto, ficou demonstrado, nos discursos da mesa, o consenso a respeito da importância de se incluir a pauta da diversidade cultural na escola, mas que estava longe de ser uma realidade e ela não se tornaria viável sem que houvesse melhoria também da qualidade de ensino e fosse solucionado o problema crônico da falta de professores nesta escola. Ou seja, o discurso a respeito da diversidade cultural não deveria ser apenas um adorno pedagógico, mas contribuir para gerar mudanças e transformações para um ensino de qualidade e para o exercício da cidadania.

Segundo Tubino (2006), construir cidadania é a tarefa mais importante que compete aos educadores. Em países onde a grande parte dos cidadãos vive em situação de pobreza, e onde não se reconhece sistematicamente que o racismo e a discriminação cultural - que estão impregnadas na vida cotidiana - são expressões privilegiadas de fraturas identitárias fundantes, somente criando as condições para o exercício pleno da cidadania é que se pode mudar o rumo dos acontecimentos. Ainda de acordo com Tubino (2006), a educação cidadã deve ser para todos - indígenas e não- indígenas -, mas não deve ser a mesma para todos. Deve ser diferenciada, significativa e adaptada às características culturais dos educandos, além de ser intercultural. Ou seja, tem de começar a "identificar, interpretar e orquestar uma multiplicidade de pontos de vista culturalmente diferenciados (sobre a cultura política), para poder propor uma comunidade argumentativa democrática, na qual todos tenham o mesmo poder de fala" (Ribeiro, 2006, p. 194 apud Tubino, 2006, p. 4).

\section{As apresentações}

Destacamos as apresentações que ocorreram anteriormente às mesas temáticas, pois acreditamos que foram elas que mais contribuíram para as propostas da Semana, por inserirem elementos das mais diversas culturas no interior da escola, demonstrando o que havia de mais rico em cada uma delas. 
$\mathrm{Na}$ noite do dia 4 de novembro, houve apresentações de dança do ventre realizadas por alunas da própria EMEF Alcântara e de dança de rua por iniciativa dos alunos do Grêmio da EMEF Alcântara. A última participação desta noite foi a de Luis Carlos da Silva, o Dj Mago, da ONG Favela Atitude, que realizou uma demonstração de hip-hop para os presentes.

Na noite seguinte, apresentaram-se os alunos do grupo de capoeira Guerreiros de Bimba, projeto coordenado por Mestre Boca, liderança comunitária do Real Parque. Capoeiristas das mais variadas idades, entre eles membros da comunidade Pankararu, se apresentaram de uma forma intensa, acompanhados pelos instrumentos musicais tocados por outros membros do grupo. O encerramento desta noite ficou a cargo do grupo musical formado por adolescentes do Professor Pitu, que realizou na quadra da escola uma apresentação musical. Organizados em três filas, os jovens músicos tocaram seus instrumentos de percussão, alguns feitos com material reciclado, em um ritmo compassado, proporcionando um espetáculo empolgante e que demonstrava a riqueza da música percussiva brasileira e também apontava um caminho para o desenvolvimento social dos adolescentes.

No dia 6 de novembro, a apresentação ficou a cargo da comunidade Pankararu, na pessoa de Bino. Com apenas um maracá na mão e com o auxílio de dois membros da comunidade Pankararu ${ }^{111}$, ele se pôs a cantar os toantes e realizar a dança em meio a uma roda de observadores presentes. Por ser uma apresentação curta, não haveria a necessidade dos Praiás estarem presentes (que estavam reservados para o dia do encerramento). Mesmo com tão poucos elementos, a dança circular e os toantes cantados foram agregando cada vez mais os presentes, que passaram a acompanhar o ritmo da dança. Pouco a pouco, os presentes começaram a se juntar à dança, aumentando o tamanho do grupo. Assim, alunos, professores e comunidade passaram a acompanhar o ritmo da dança, criando um clima bastante festivo e de confraternização. Por fim, Jurandir Siridiwê, da etnia Xavante, também participante da mesa, se dispôs a ensinar os presentes a dança tradicional de seu povo, que se caracteriza por uma roda em que os participantes se colocam um ao lado do outro, entoam uma música tradicional e realizam um movimento de abrir e fechar de pernas ao ritmo da música.

Considerei estas apresentações interessantes porque dificilmente as escolas se disporiam a se abrir para manifestações culturais indígenas dessa forma e, nesse caso, pudemos ver que a comunidade escolar se dispôs a acolher de forma bastante

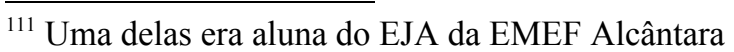


participativa quaisquer manifestações de diferença em seu interior, constituindo-se, portanto, em momentos privilegiados que podem contribuir para arrefecer as manifestações preconceituosas em relação às etnias minoritárias presentes na escola.

A demonstração do dia 7 de novembro ficou a cargo de dois praticantes de karatê, que realizaram uma demonstração de uma graduação de passagem de faixa, onde demonstraram diversos golpes utilizados nesta luta marcial. Nesse sentido, houve uma inserção de uma arte de luta oriental para ampliar ainda mais a diversidade cultural proposta durante a Semana.

Isso nos faz pensar na proposição de Moreno (1988) de retirar as disciplinas científicas de suas torres de marfim e deixá-las impregnar-se da vida cotidiana, de modo que os temas transversais, considerados como categorias de conhecimento que estão imbricados no cotidiano e em questões sociais atuais, sejam colocados como eixos curriculares básicos, sem que isto pressuponha renunciar às elaborações teóricas essenciais para o avanço da ciência. Ou como o proposto no Projeto Culturas Juvenis, de verificar como a cultura escolar pode se beneficiar de uma aproximação intelectual e afetiva do amplo espectro de manifestações culturais juvenis e étnicas, de modo a identificar nelas os elementos necessários para se repensar a própria escola, seu funcionamento e seus currículos (cf. Amaral, 2006).

\section{As discussões das mesas temáticas}

As discussões realizadas nas mesas temáticas serão descritas em linhas gerais, de maneira a sintetizar nosso trabalho. A mesa temática do dia 4 de novembro era sobre o "Ensino obrigatório de culturas e histórias afro-brasileiras e indígenas e pluralidade

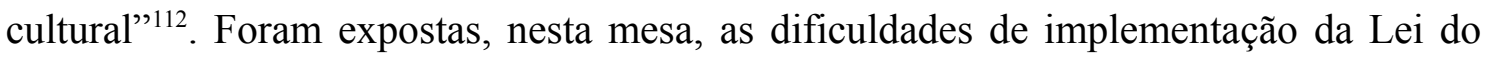
Ensino obrigatório na escola ${ }^{113}$. Embora a promulgação desta Lei fosse considerada importante, a opinião que foi colocada na mesa é que ela havia sido promulgada tardiamente, e, além disso, caracterizava-se por relativa ambigüidade, pois não oferecia instruções nem condições concretas para que fosse efetivamente implementada, além de não explicitar a necessidade da capacitação dos professores para promover a inserção desta temática na escola. Em suma, tornou-se apenas uma Lei prescritiva, em uma clara demonstração de dever cumprido, uma vez que tratava-se apenas de uma pauta pendente

\footnotetext{
${ }^{112}$ Os participantes desta mesa foram o Supervisor de educação da regional Butantã C., F.S., estudante de Direito da USP e Filosofia da PUC, a supervisora pedagógica F.,

${ }^{113}$ Lei $10.639 / 03$ e posterior Lei $11.645 / 08$.
} 
para o Estado. Este tentava responder a uma reivindicação dos movimentos sociais de há muito tempo por esse espaço na educação, mas sem que se dispusesse a realizar ações para uma efetiva transformação no currículo escolar.

A mesa temática do dia 5 de novembro teve como título "Cultura e história afrobrasileira" 114 . Foi interessante notar que muitos dos que constavam na programação para a discussão nesta mesa não estiveram presentes, passando a mesa temática a ser composta por pessoas que tinham uma atuação social bastante relevante na comunidade do Real Parque, como o capoeirista mestre Boca, o professor Pitu e o DJ Mago, o que enriqueceu muito o debate. Em termos gerais, eles relataram suas trajetórias na comunidade e da vital importância que as atividades exerciam (capoeira, música e hiphop) em suas vidas e nas dos jovens a quem se dedicavam a ensiná-los, enfatizando a questão de que estes elementos culturais auxiliavam a incutir valores, como disciplina e responsabilidade, nos jovens. A comunicação de DJ Mago foi bastante interessante por ele já ter sido aluno da EMEF Alcântara. Ele frisou que a proposta da Semana havia sido um salto qualitativo, porque a discussão a respeito da questão afro-brasileira na escola, em seus tempos de estudante, era insignificante e que a escola devia estar aberta para esta questão há muito tempo. Referindo-se ao passado histórico dos afrobrasileiros, enfatizou a miscigenação e a grande contribuição destes que foram responsáveis pela grande e variada riqueza cultural no Brasil. Ressaltou, ainda, a importância de que cada afro-brasileiro se afirmasse como tal, havendo também a necessidade de reparação aos afro-brasileiros por parte da sociedade.

A mesa temática do dia 6 de novembro foi "Cultura e história indígena"115. Apesar de todas as dificuldades de composição desta mesa na etapa de organização, acredito que contribuímos para o "protagonismo" dos próprios indígenas. Em todas as comunicações, fez-se presente a defesa da história e cultura indígena e das peculiaridades de cada etnia indígena presente; ao mesmo tempo, denunciaram os estereótipos construídos sobre os indígenas e a discriminação da qual são vítimas na cidade, bem como as estratégias delineadas para enfrentar uma situação como essa. Dora Pankararu fez então o seu relato da trajetória dos indígenas Pankararu em São

\footnotetext{
${ }^{114}$ Estiveram presentes nesta mesa a diretora G., da EMEI Pero Neto, além do capoeirista João Ulisses de Rezende, o "Mestre Boca" (professor de capoeira da comunidade do Real Parque), Professor Pitu (Projeto Pitu Leal Percussão Artesanal), Alteia Turpin, diretora da EMEF Dom Veremundo Toth, e Luis Carlos da Silva, o Dj Mago, da ONG Favela Atitude.

${ }^{115}$ A mesa temática da noite foi composta por Jurandir Siridiwé Xavante (presidente da ONG IDETI Instituto de Tradições Indígenas), Maria das Dores Prado "Dora" (comunidade Pankararu), Marcos Aguiar (coordenador da ONG Opção Brasil) e Edson Machado de Brito Kayapó (doutorando em educação pela PUC/SP).
} 
Paulo e todos os desafios enfrentados por eles nesta cidade, demonstrando, contudo, como a comunidade tem se posicionado para afirmar sua cultura e sua identidade neste meio. Ressaltou a importância da escola para diminuir o preconceito ali vivido e também considerou "vergonhosa" a pouca atenção dada pelo governo aos indígenas na cidade e a dificuldade de se criar um Centro de Referência Indígena no Real Parque, estando o bairro tão próximo do Palácio do Governador.

O espaço aberto para a discussão da causa indígena aos alunos e professores foi muito importante para que a comunidade escolar presenciasse os próprios indígenas falando a respeito das condições em que viviam e as batalhas travadas pelas comunidades para se reafirmar em sua cultura e identidade. Isso estava sendo dito por pessoas que experimentavam em seu cotidiano o que estava sendo discutido ali, e elas estavam presentes à sua frente e na própria escola e não somente por meio de livros didáticos. É esse contato que pode oferecer condições para superar o preconceito e a discriminação aos indígenas e afro-brasileiros tão presentes na escola.

A última mesa de discussões, do dia 7 de novembro, teria como tema: "Preconceito e discriminação étnica, sexual e religiosa" $"$. O intuito de realizar esta mesa seria o de concluir as discussões a respeito das temáticas indígenas e afrobrasileiras e inserir também discussões sobre a discriminação sexual e religiosa.

Um poema escrito pelo professor L. entitulado Vista a minha pele (Anexo VI), que trata justamente da discriminação aos afro-brasileiros, foi lido por uma das professoras de modo bastante envolvente. Cada verso do poema declamado em meio a lágrimas pela professora - também afro-descendente - emocionou todos que estavam presentes. Foi desse modo que se deu início à mesa temática.

As discussões envolveram os estereótipos que cercam os afro-brasileiros, principalmente no tocante à sua religião e mesmo no cotidiano escolar, discutidas por duas professoras afro-brasileiras da EMEF Alcântara; a necessidade de se respeitar a visão de mundo de cada povo indígena, principalmente no trabalho realizado em relação às questões de saúde, como demonstrou Marcos Shaper; a necessidade de se ter uma visão das relações amorosas e do erotismo despida de preconceitos, como demonstrado por Tatiana Karinya Rodrigues, a partir de uma leitura de um mito de Aristófanes presente na obra $O$ Banquete, de Platão. Por fim, a necessidade de maior respeito e

\footnotetext{
${ }^{116}$ Foram participantes dessa mesa Marcos Shaper (coordenador do Projeto Xingu e do Ambulatório Indígena da Unifesp), Tatiana Karinya Rodrigues (psicóloga e mestre em educação pela FEUSP) e três professoras da EMEF Alcântara R., O. e A., além da participação da coordenadora pedagógica B. A mesa ficou sob a coordenação de Mônica do Amaral (professora doutora da FEUSP).
} 
consideração por todos os que possuem características qualificadas pelo mundo dos brancos como sendo "diferentes", como apresentado por uma professora da EMEF Alcântara.

Pudemos observar, nessa mesa, que a temática proposta envolveu um amplo espectro de assuntos, abordando praticamente todas as formas de discriminação, e desse modo, contribuiu de forma interessante para a finalização do debate promovido por todas as mesas realizadas durante a Semana. Um ponto importante foi a abertura para perguntas das pessoas presentes para os que estavam na mesa, que ficou sob os cuidados da coordenadora pedagógica. Uma das perguntas mais interessantes foi de uma aluna da EJA, que questionou se, diante de todas as discussões realizadas, haveria de fato mudanças na escola a respeito da discriminação e se a lei 11.645 seria de fato colocada em prática. A coordenadora respondeu que a Semana foi o primeiro passo para isso e que o trabalho de mudança deveria ser o resultado de um esforço conjunto, assim como a Semana foi fruto de um trabalho coletivo. Também chamou a atenção um comentário de um aluno, que disse ter mudado muitas de suas concepções e a forma de encarar as coisas devido a tudo que observou e acompanhou na Semana. A coordenadora observou nisso já os primeiros resultados de todo o trabalho realizado na Semana.

\section{Atividades sobre a questão indígena realizadas com os alunos}

Entre as atividades realizadas para os alunos sobre a questão indígena, estava uma sessão de vídeo com o documentário "Das crianças Ikpeng para o mundo" "117, que seria apresentado por mim. Neste filme, quatro crianças Ikpeng falaram de sua aldeia, localizada no Parque Indígena no Xingu, no Mato Grosso, em resposta a um vídeo-carta das crianças da Sierra Maestra em Cuba. Assim mostram o cotidiano de suas vidas, famílias, brincadeiras, festas e modo de vida de uma forma muito descontraída e divertida, sendo uma opção bastante interessante de trabalhar com a questão indígena em sala de aula para alunos mais jovens. Neste evento, realizamos três sessões com alunos da $6^{\mathrm{a}}, 7^{\mathrm{a}}$ e $8^{\mathrm{a}}$ séries. Foi interessante observar que, em cada uma das salas que acompanharam as sessões, havia alunos Pankararu.

A primeira sessão foi com alunos da $6^{\mathrm{a}}$ série. Eles entraram na sala de vídeo com a professora do período, que iria acompanhar a atividade. A coordenadora pedagógica do período da manhã, assim que chegou, relatou que a classe havia se comportado

${ }^{117}$ Das crianças Ikpeng para o mundo (Marangmotxíngmo Mïrang), 2001, direção e fotografia: Kumaré, Karané e Natuyu Yuwipo Txicão. 
muito mal em uma sessão anterior de vídeo (sobre os Racionais Mc's) e por isso ela iria conversar com eles. Em um tom severo, repreendeu os alunos pelo comportamento que tiveram e disse que não iria tolerar nenhum mau comportamento da classe na sessão de vídeo. Depois da advertência da coordenadora, iniciei a sessão de vídeo dando uma pequena explicação a respeito dos Ikpeng, a localização geográfica da aldeia e algumas características culturais. Em seguida, dei início ao filme. A despeito do comportamento que tiveram na outra sessão de vídeo, os alunos acompanharam com muito interesse o filme, fazendo comentários entre eles diante de algumas cenas do vídeo. Com o fim do filme, fiz um pequeno debate, perguntando o que chamou a atenção deles e os alunos passaram a refletir acerca de alguns dos trechos que viram. Fiz uma pergunta sobre o que era diferente e o que não era para eles. Alguns comentaram que certas coisas eram muito diferentes e outras não, dizendo que eles eram crianças como todas as outras, mas que tinham alguns costumes diferentes. Com base nisso, comecei a lhes explicar como a escola e os livros didáticos mostravam um índio genérico, sendo que havia diversas etnias, com suas próprias línguas e costumes e que não poderíamos pensar no índio de uma forma única. Dito isso, passei algumas cenas de um vídeo Pankararu (feito por ocasião da visita de Maíra Ferreira nas terras indígenas no Nordeste) e busquei demonstrar que não deveríamos nos basear em estereótipos para falar do indígena. Na passagem destas cenas, uma aluna Pankararu ficou bastante constrangida e até pôs as mãos no rosto, como se quisesse esconder, embora não houvesse nenhum comentário negativo por parte dos outros colegas. Um indicativo de como os alunos Pankararu não se sentiam à vontade quando se comentava em sala de aula a respeito de sua própria etnia, como se ela não quisesse expor em público o seu pertencimento étnico. Isso me fez refletir a respeito de como os professores deveriam inserir a temática indígena, em especial, os Pankararu, sem que isso pudesse criar situações delicadas para os próprios alunos indígenas. De qualquer modo, pude observar que os alunos acompanhavam tudo com bastante interessante, o que me fez refletir que a temática indígena tem a possibilidade de ser bem trabalhada na escola, de modo a auxiliar a dirimir estereótipos e preconceitos em relação aos próprios indígenas.

Em relação à turma da $7^{\mathrm{a}}$ série, a sessão de vídeo transcorreu de forma parecida. No entanto, ao passar as cenas sobre os Pankararu, os alunos começaram a apontar para uma aluna, comentando que ela era Pankararu, fazendo com que a aluna ficasse nitidamente constrangida, tornando visível que a inclusão da temática indígena em sala de aula deveria ser feita de uma forma bastante delicada e cuidadosa, pois ficou nítido 
que a escola em si não estava preparada para isso. Nesse sentido, a inclusão poderia estar agindo de forma a excluir, na realidade, o próprio aluno de uma etnia minoritária.

$\mathrm{Na}$ sessão realizada para a $8^{\mathrm{a}}$ série, embora os alunos demonstrassem acompanhar com bastante interesse o filme, pude sentir diferenças na forma como os alunos encaravam as cenas mostradas nele. Havia maior estranhamento em relação ao que consideravam diferente em relação aos indígenas, principalmente no tocante à nudez dos próprios indígenas, que não havia causado nenhuma reação de espanto nas outras séries, e alguns aspectos culturais que poderiam ser considerados não tão usuais segundo uma ótica eurocêntrica. Duas alunas Pankararu estavam presentes na sala, sendo que elas estavam justamente na classe na qual fizemos as intervenções anteriormente $^{118}$. No momento da exibição de cenas na comunidade Pankararu, uma das alunas, em tom de chacota, pareceu se assustar com a visão dos Praiás, referindo-se a eles como se fossem "fantasmas". Em uma outra cena, elas observaram a presença de uma ex-aluna do Alcântara, que era Pankararu, e que havia se mudado para a Terra Indígena no Nordeste. Em alguns momentos, houve provocações às alunas Pankararu. Noutros momentos, uma das alunas Pankararu começou a ter atitudes de provocação em relação a mim no decorrer da atividade, deixando-me a impressão de que estava se sentindo bastante incomodada em relação ao assunto abordado. Em um determinado momento, ela pediu para sair da sala para ir ao banheiro e não retornou. A outra aluna Pankararu presente permaneceu em silêncio durante toda a atividade ${ }^{119}$.

Fazendo uma análise geral de todas as sessões realizadas, conclui que é possível, sim, a despeito das dificuldades encontradas, realizar uma atividade com a temática indígena sem que se estimule a criação de estereótipos. Mas pude observar também uma postura bastante diferente entre os alunos em relação à questão indígena de acordo com a série em que estavam. Pareceu-me que a intolerância ao diferente pareceu se acentuar de acordo com a faixa etária, incluindo-se aí as reações dos próprios alunos Pankararu diante do tema que se mostraram cada vez mais intensas. De qualquer modo, pude perceber que a inclusão da temática indígena na escola torna-se bastante delicada sem uma abordagem adequada. Em um ambiente escolar onde ainda predomina preconceitos e estereótipos em relação às etnias minoritárias, uma inserção deste assunto em sala de

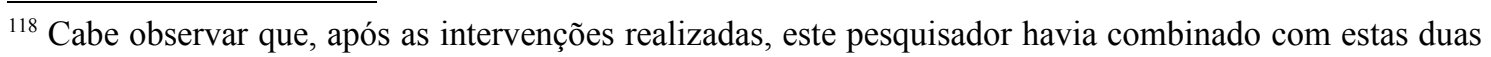
alunas em realizar uma oficina de redação somente com alunos Pankararu. Após uma aceitação inicial, estas duas alunas recusaram veementemente um contato ou um diálogo com este pesquisador, como se a insistência em reafirmar uma identidade indígena fosse bastante incômoda.

${ }^{119}$ Encontrei esta aluna em outras atividades da comunidade Pankararu, onde toda a sua família estava presente e participativa, e na tentativa de estabelecer um diálogo, esta se mostrou bastante retraída.
} 
aula, principalmente na presença de alunos indígenas, pode contribuir ainda mais para a exclusão destes alunos em vez de auxiliá-los na afirmação de sua identidade étnica.

Segundo Veiga-Neto (2003), simplesmente “aceitar a diferença” pode ser um termo que, embora carregue uma noção de tolerância, pode revelar uma postura étnica conservadora, que serve apenas para encobrir e, desse modo, reforçar e perpetuar a própria desigualdade. A defesa da inclusão pode implicar a aceitação do diferente, mas também pode promover o desaparecimento da própria diferença ao extingui-la e assim conduzir à colonização e anulação do outro. Isso pode ocorrer de três formas: transformar o outro (ou seja, anular o que o outro tinha de si próprio), fazer do outro um simulacro ou um estereótipo (em outras palavras, fazendo-o se sentir ridículo diante da boa imagem que faço de mim mesmo) ou simplesmente eliminar o outro.

De acordo com Veiga-Neto (2003), não se pode confundir diferença com desigualdade, ainda que esta distinção seja difícil.

"Penso que devemos tê-la (a distinção) sempre em mente, lutar por ela; ou seja, lutar para que se mantenham, ao mesmo tempo, a diferença e a igualdade. Mas isso precisa de medidas e precauções muito mais difíceis do que simplesmente pensar na escola como um lugar de convívio, num lugar capaz de aplainar as diferenças" (Veiga-Neto, 2003, p. 212).

Assim, configura-se novamente uma relação paradoxal na escola entre uma reivindicação universal pela igualdade de direitos, e a garantia do direito particular a uma educação diferenciada dos indígenas, que se configura como uma equação difícil de ser resolvida.

\section{A atuação dos professores na Semana}

Em relação à atuação dos professores da EMEF Alcântara, pude observar que alguns deles acompanharam com muito interesse e praticamente participaram de todos os eventos com entusiasmo, atuando inclusive nas oficinas e na preparação dos alunos 
para as apresentações, mas, por outro lado, muitos outros tiveram um envolvimento apenas burocrático, limitado apenas aos seus horários de trabalho e tratando as atividades como algo corriqueiro. Assim, perderam a oportunidade de uma aproximação intelectual e afetiva das diversas manifestações culturais apresentadas pelos alunos e pelos grupos étnicos presentes na comunidade no entorno da escola. Mesmo com a busca da inserção de uma discussão sobre a diversidade cultural na escola, seria necessário que os professores deixassem de ser meros funcionários técnicos e passassem a assumir um papel de intelectual transformador, atuando para a emancipação política, intelectual e social dos alunos. Como uma das supervisoras pedagógicas comentou durante o encerramento, grande parte do trabalho da Semana veio de fora da escola, cabendo aos professores, em diversos momentos, apenas o papel de observadores, e não como algo procedente de um trabalho intelectual do próprio corpo docente. Além disso, ainda havia muito a ser feito no sentido de se promover mudanças na mentalidade etnocêntrica prevalecente na escola. Para se ter uma idéia do trabalho a ser feito com o corpo docente nesse sentido, basta analisar um comentário de uma das professoras: ao falar a respeito do que seria oferecido no almoço típico dos indígenas Pankararu no sábado do encerramento, perguntou, em tom de brincadeira, se seriam oferecidas “criancinhas" nas refeições, remetendo-se à idéia de antropofagia relatada sobre os indígenas no passado. Embora parecendo algo sem propósito, isso se mostra bastante revelador da visão que os professores, em geral, possuem a respeito dos indígenas que, com certeza, repercutiria na visão dos próprios alunos. E isso aconteceu mesmo depois de ter presenciado indígenas politicamente ativos, buscando espaços no cenário nacional, reivindicando seus direitos e presentes em universidades em uma das mesas temáticas da Semana.

\section{A produção dos alunos para a Semana}

Os professores realizaram trabalhos com os alunos a respeito da diversidade cultural como uma preparação para a Semana, sendo abordadas nas atividades as histórias e culturas indígenas e afro-brasileiras com os alunos. Todo esse trabalho foi 
exposto durante a Semana nos murais da escola. Como fora observado em anos anteriores, principalmente em comemorações do Dia do Índio, prevaleciam ainda, nos cartazes realizados pelos alunos imagens estereotipadas dos indígenas, sendo retratados, na maior parte das vezes, com flechas na mão, penas como adornos nas cabeças, morando em ocas e descansando em redes. Apesar disso, um fator muito positivo observado na produção dos cartazes foram as letras de rap e cartazes elaborados por alunos Pankararu que afirmavam, sem nenhum receio, a sua identidade étnica. Em um dos cartazes, uma das alunas compôs a seguinte letra de rap:

Rap dos Pancararus

De: Luciara, Clayton e Alexia

Eu sou índio pancararu

Nós não devemos para nenhum

De cá ou de lá somos Pancararu

Nós moramos no real sul

Digo isso para rimar

Porque nós somos pancararu

Porque todo mundo do real sul

Tem orgulho de ser um

Dos primeiros habitantes

do Brasil e do Real

$\mathrm{Na}$ América do Sul

Um povo muito legal

Um outro rap:

De: Luciara e Alexia

Eu mando minha rima

é logo de caneta 
eu sou pancararu

ta ligado é muita

TETRA!!!

Eu mando essa rima

Lá do Real Sul

As meninas chapa quente

É tudo pancararu

Com estes alunos Pankararu da $3^{\mathrm{a}}$ série da EMEF Alcântara fazendo estas letras de rap e exaltando o orgulho de se auto-afirmarem, podemos vislumbrar a possibilidade de que os alunos indígenas não tenham, no futuro, o receio de manifestarem a sua identidade indígena na escola.

\section{O encerramento}

As atividades de encerramento se iniciaram às $9 \mathrm{~h}$ da manhã. Logo pela manhã, todos os mantimentos necessários para a refeição que seria oferecida pela Associação dos Pankararu foram trazidos para a cozinha da escola, assim como os Praiás também levados para uma sala especial na escola. A presença das pessoas da comunidade era inicialmente tímida, mas foi se avolumando no decorrer do tempo e ganhando espaço na escola. Os professores estavam em peso repondo um dia de feriado ${ }^{120}$.

Nesse meio termo, eram realizadas as demonstrações de artes marciais e também uma dança típica por uma mulher nativa das Ilhas Polinésias, que estava de passagem no Brasil visitando a comunidade Pankararu no Real Parque, preparando a entrada para o Toré Pankararu.

A partir das $11 \mathrm{~h}$ da manhã, com os Praiás posicionados na quadra, Bino Pankararu deu início ao canto dos torés e toantes, de modo que fosse possível realizar a abertura do ritual. Era necessário dançar o que os Pankararu denominam de "três rodas", que são três danças circulares no terreno em que o Toré seria realizado. Esse

\footnotetext{
${ }^{120}$ Um problema que acabou por atrapalhar as atividades da manhã foi o de que as oficinas que estavam a cargo da ONG Favela Atitude não foram realizadas em razão da ausência de seus membros. A única oficina que pode ocorrer foi a de Artes Marciais, realizada por um professor de Karatê na quadra de esportes. Assim, na parte da manhã, as atividades se restringiram somente aos trabalhos de cerâmica do Projeto Aprendiz e da apresentação de teatro do grupo Doutores da Alegria.
} 
procedimento ritual foi necessário para que o almoço pudesse ser servido para os presentes. O Toré foi assistido com muito interesse pelos presentes. Muitas pessoas da comunidade Pankararu estavam presentes, assim como muitos alunos Pankararu também, participando todos da dança.

Logo após as "três rodas", os Praiás se recolheram, recebendo antes a refeição em cuias de barro, como deve ser ritualmente feito. As primeiras cuias de comida foram entregues aos Praiás, cabendo ao mais importante, chamado de "Capitão" a cuia maior. Como é de praxe nos rituais Pankararu, a comida ${ }^{121}$ é servida para todos os participantes do evento.

Posteriormente tivemos a chegada dos indígenas da etnia Wassu, que também realizariam seu Toré para os presentes. A apresentação do Toré dos Wassu, que se distinguia dos Pankararu por não utilizar indumentárias como os Praiás, mas que se apóia fortemente no canto, veio trazer mais um elemento de força para a apresentação dos indígenas na escola. Posteriormente, Bino iniciou o canto de toantes que acabou envolvendo indígenas Pankararu e Wassu em rodas. A partir de um determinado momento, as danças estavam abertas para todos que desejassem participar, envolvendo as pessoas que estavam presentes.

Com o intervalo dado pelos Torés indígenas, chegou o grupo de percussão do professor Pitu, que havia participado durante a Semana das atividades e veio dar um ritmo e uma sonoridade intensos às festividades na escola. Logo após a apresentação de percussão, foi a vez dos Praiás entrarem em cena para encerrar os eventos. Ritualmente seria necessário que fosse realizado o Toré de encerramento na quadra. Foi nesse clima de intensa confraternização que a participação dos Praiás se encerrou. Bino e Dora, por fim, em nome da comunidade Pankararu, agradeceram à escola que permitiu a abertura para os eventos, assim como todos os participantes e os que possibilitaram a realização da Semana.

No final, por solicitação de Dora, uma vez que as oficinas da parte da manhã não haviam sido realizadas, DJ Mago e um outro membro da ONG Favela Atitude deram uma demonstração de improviso de hip-hop para os presentes no evento. Assim se deu o encerramento do evento, que, apesar de diversos imprevistos e atividades que não foram concretizadas, foi extremamente positivo no sentido de incluir a temática indígena e afro-brasileira de forma bastante contundente na EMEF Alcântara. Tornou-se assim

${ }^{121}$ A refeição é composta basicamente de arroz e carne de porco, juntamente com farinha, sendo uma comida típica do Nordeste. A diferença que é realizado um trabalho "espiritual" antes que ela seja servida. Como bebida, é servida a garapa de cana. 
uma prova de que, havendo um mínimo de comprometimento por parte de todos, é possível que a escola se abra para a comunidade e a toda a contribuição que pode trazer a ela. 


\section{Considerações finais}

Ao longo desta dissertação, pudemos observar a mobilização política dos indígenas Pankararu tanto no Nordeste como em São Paulo em busca de melhores condições de sobrevivência e de afirmação de sua cultura e identidade indígenas. Em meio a um processo histórico de colonização do Nordeste, caracterizado por uma política de extermínio, exclusão e assimilação dos nativos, os Pankararu, na luta por seus direitos e por suas terras tradicionais, engendraram um processo de emergência étnica que, ao fomentar uma identidade contrastante em relação à sociedade circundante por meio do Toré (ritual formado por elementos religioso-culturais, como o culto aos Encantados e o uso da indumentária Praiá), constituiu-se e se unificou étnica e politicamente como grupo étnico. Desse modo, tem contrariado muitos dos pressupostos acadêmicos e governamentais que afirmam que os povos indígenas desta região teriam sido integrados à sociedade e, portanto, extintos do cenário nacional.

Como evidência contrária a essa visão integracionista, vemos que os Pankararu em São Paulo, ao migrarem para a metrópole nas décadas de 1940/50, vêm se constituindo como um grupo étnico politicamente atuante, por meio de suas associações e em busca de seus direitos diferenciados. Ao se estabelecerem nas grandes cidades, foram considerados como indivíduos que renunciaram à sua condição indígena e, conseqüentemente, aos direitos garantidos pela legislação. Ao buscarem se valer desses direitos, eles acabam se tornando vítimas de diversos tipos de preconceito e discriminação (ainda não devidamente caracterizados pela legislação), que consistem em desqualificar suas pretensões aos lhes negar sua identidade indígena e, conseqüentemente, negando-lhes seus direitos.

Nesse sentido, os Pankararu reivindicam que os órgãos governamentais os tratem como cidadãos, o que implica afirmar que eles possuem direitos como todos os outros brasileiros, ao mesmo tempo em que solicitam uma atenção especial como detentores de direitos diferenciados. Evidencia-se assim a relação paradoxal entre uma reivindicação universal pela igualdade de direitos e a garantia do direito particular à diferença dos indígenas. De modo a garantir isso, a visibilidade e a identidade dos indígenas perante a sociedade e os órgãos públicos tem sido uma preocupação constante por parte destes grupos indígenas. Justamente para adquirir esta visibilidade, a cultura adquire uma nova função para os indígenas, deixando de ser uma categoria analítica antropológica para se tornar objeto de reflexão do próprio grupo étnico a respeito de si 
mesmos e expectativas dos "outros", e também um instrumento de ação política. Assim, podemos notar que as reivindicações dos Pankararu em São Paulo têm se direcionado para três áreas específicas: a terra, saúde e educação. No que diz respeito a esta última, exigem uma educação diferenciada, como parte de uma atenção fundamental às suas demandas, pois os indígenas têm se conscientizado que, mesmo morando em cidades, necessitam de um ensino que esteja atento às peculiaridades do contexto sócio-cultural em que vivem. Assim clamam por uma melhor formação para os professores da rede de ensino municipal, no sentido de inserir a temática da cultura e história indígenas nas salas de aula, decorrente do fato de ela estar sendo menosprezada nas escolas. Do mesmo modo, reconhecem a necessidade de um espaço que dê condições a eles de transmitir as tradições indígenas e capacitação profissional, que seria, no caso, um Centro de Referência Indígena, uma vez que o fato de morarem em uma cidade grande contribui para a dispersão da comunidade, considerando-se que a escola, por si mesma, não tem cumprido essa função.

Todas essas demandas fazem sentido quando observamos a situação dos alunos Pankararu na EMEF Alcântara. Em contraste a toda uma mobilização étnica verificada em contexto nacional, observamos na escola uma desvalorização da identidade indígena. Situações marcadas pela estereotipia, preconceito e discriminação na escola fazem com que a figura do indígena assuma uma conotação negativa perante alunos e professores - como pudemos observar in loco, na análise de questionários direcionados aos alunos e nas intervenções realizadas em salas de aula - atingindo, de forma profunda, a subjetividade dos alunos Pankararu. Nesse sentido, é a própria cultura escolar, na qual se encontram mergulhados professores e alunos, que marginaliza a história e as culturas das minorias étnicas. Propostas de mudanças curriculares na educação brasileira, como as discussões sobre multiculturalismo e a inclusão obrigatória das histórias e culturas indígenas e afro-brasileiras, não tem surtido o efeito necessário para combater a discriminação às etnias minoritárias na escola, o que demonstra a dificuldade existente em se transformar a mentalidade dos próprios agentes escolares e suas concepções e práticas pedagógicas. Não é de se estranhar, portanto, que os alunos Pankararu possuam uma relação ambivalente com a sua própria identidade étnica, ao não se declararem indígenas na escola como expressão de uma possível autodefesa, motivada pela discriminação exercida por parte tanto dos alunos como do próprio corpo docente. Estudos revelam que situações contínuas de discriminação podem despertar nas crianças indígenas uma consciência negativa de si, o que podemos chamar de 
"identidade negativa", que pode se prolongar nos períodos da adolescência e maturidade, dificilmente se transformando assim em uma identidade positiva que seja capaz de auxiliar o indivíduo ou o grupo a enfrentar situações adversas no tocante à sua etnicidade. Se pensarmos na hipótese de determinados pesquisadores de que crianças, em sua tenra idade, já demonstram sinais de intolerância racial ou consciência étnica, faz-se necessário que o trabalho para um respeito à diferença ou afirmação étnica seja realizado já no início do aprendizado das crianças, ou seja, nas séries iniciais da escola.

Em relação ao trabalho de pesquisa realizado na escola, intervenções foram realizadas no intuito de permitir que os professores pudessem ter contato com a realidade vivida pelos alunos em geral, incluindo os Pankararu, e reuniões após as intervenções seriam momentos nos quais os professores poderiam discutir e refletir a respeito de seu relacionamento com os alunos, da teoria e da prática pedagógica e de suas próprias concepções de mundo.

Nestas intervenções, os próprios professores puderam entrar em contato com a realidade dilacerante da discriminação sofrida pelos alunos Pankararu e também pelos alunos não-indígenas, devido ao fato de morarem em uma comunidade pobre no interior de um bairro de classe alta, e assim repensar muitas de suas concepções pedagógicas e visões de mundo, principalmente pelo fato de reconhecerem nas atitudes do próprio corpo docente em sala de aula atos discriminatórios em relação aos alunos. No entanto, não nos pareceu suficiente que a vivência desta realidade tivesse sido compartilhada por apenas um grupo de professores, mas se torna necessário que ela fosse estendida para toda a comunidade escolar. Tornou-se visível que a cultura escolar deveria ser transformada em seu interior, mas para tanto, seria necessário que os próprios professores, ao se permitirem ter um ouvido atento e sensível à realidade e demandas dos alunos, entrassem em contato com seus próprios preconceitos e falta de sensibilidade social e estivessem dispostos a repensá-los e transformá-los.

De certo modo, a Semana de Diversidade e Cultura, organizada sob a iniciativa dos Pankararu, teve o propósito de realizar um diálogo intercultural com o corpo docente e a comunidade, inserindo a temática indígena e afro-brasileira na EMEF Alcântara. Uma proposta intercultural significa que o diálogo entre as culturas poderia ser desenvolvido por meio do respeito mútuo, sem hierarquias entre elas e sem "folclorizá-las". Desse modo, buscou-se uma transformação, ainda que inicial, na cultura escolar da EMEF Alcântara, de modo que as etnias minoritárias fossem consideradas. A proposta de envolver as próprias comunidades no interior da escola na 
organização da Semana se tornou bastante produtiva, pois assim as culturas minoritárias estariam colocadas em um mesmo patamar nas discussões e nas atividades propostas em relação à cultura escolar. As apresentações, discussões e atividades com os alunos colocaram em pauta as histórias e culturas indígenas e afro-brasileiras, as questões do preconceito e da discriminação dentro da escola de forma geral, e alcançou resultados bastante satisfatórios, como pudemos observar nos trabalhos apresentados pelos alunos Pankararu ou na participação dos alunos nas atividades propostas.

A realização da Semana, no entanto, nos apresentou outros aspectos a serem considerados. Na criação de um espaço de diálogo entre os diversos atores presentes na escola, determinados interlocutores não se dispuseram a realizar esse intercâmbio cultural, como foi o caso dos órgãos governamentais, que se omitiram no momento em que foram chamados a contribuir para a realização das atividades, e também por parte dos professores, que participaram de forma burocrática da Semana. Desse modo, tornase visível a dificuldade dos órgãos do governo responsáveis pelo ensino de lidar com a existência de histórias e culturas minoritárias dentro da própria escola.

Além disso, estes mesmos órgãos precisam se mobilizar efetivamente para a melhoria do ensino oferecido aos alunos, como, por exemplo, empenhando-se na contratação de professores (para minimizar a falta de docentes em sala de aula) e oferecer capacitação adequada aos professores já presentes, o que não tem ocorrido na EMEF Alcântara. Afinal, uma educação cidadã, digna e de qualidade deve ser disponibilizada a todos, sejam eles indígenas ou não-indígenas. Na realidade, para que a escola possa ter condições de oferecer um ensino de qualidade, capaz de abarcar a complexidade das demandas de seus alunos, incluindo os novos sujeitos históricos presentes nas salas de aulas, observamos que há a necessidade de se repensar os princípios segundo os quais a escola construiu suas bases, tema que mereceria um outro trabalho de pesquisa.

Nesse sentido, se a escola ainda não tem se demonstrado capaz de atuar de forma satisfatória no trabalho com a questão indígena, faz sentido então o desejo da comunidade Pankararu de que se crie um Centro de Referência de Cultura Indígena no bairro Real Parque, com um currículo diferenciado que contribua para o fortalecimento da identidade indígena Pankararu, principalmente entre as crianças, paralelamente à educação básica escolar. Acreditamos que a criação deste Centro de Referência e de um currículo diferenciado, por parte da comunidade Pankararu, deve ser um passo a ser tomado para o fortalecimento da identidade étnica do grupo indígena. Tornar-se-ia 
necessário um estudo mais aprofundado em relação ao projeto pedagógico desenvolvido nas escolas indígenas Pankararu do Nordeste para que fosse possível pensar em seus desdobramentos no contexto indígena em São Paulo, uma proposta que o presente estudo pretendeu dar os primeiros passos. 


\section{Anexos}

\section{Anexo I}

\section{Questionário para os alunos}

EMEF José de Alcântara Machado

$1^{\circ}$ nome: Série: Idade:

Bairro: ( ) Real Parque ( ) Jardim Panorama ( ) Paraisópolis

( ) Outros. Qual?

1. Em que cidade você nasceu? E os seus pais?

2. Descreva sua família. Como é seu relacionamento com seus pais?

3. O que a escola representa para você hoje?

4. Quais as dificuldades que você enfrenta no mundo de hoje?

5. Quais os movimentos culturais presentes em sua comunidade? Com quais deles você se identifica?

6. Você participa de algum destes movimentos? De que forma?

7. Que cantores ou grupos musicais você mais gosta? Cite uma frase ou trecho de música que mais chama a sua atenção.

8. Você conhece os Pankararus? O que sabe sobre eles?

9. O que você conhece sobre a cultura negra?

10. Nessa escola, você encontra espaço para se manifestar culturalmente? Como? Caso contrário, o que você sugere?

11. Quais mudanças você sugere para que a escola melhore?

12. Como você imagina seu futuro? Tem algum objetivo na vida?

13. O que você pode fazer para atingir esses objetivos?

14. Como o professor e a escola podem contribuir para o seu futuro? 


\section{Anexo II}

Folder da I Semana de Diversidade e Cultura

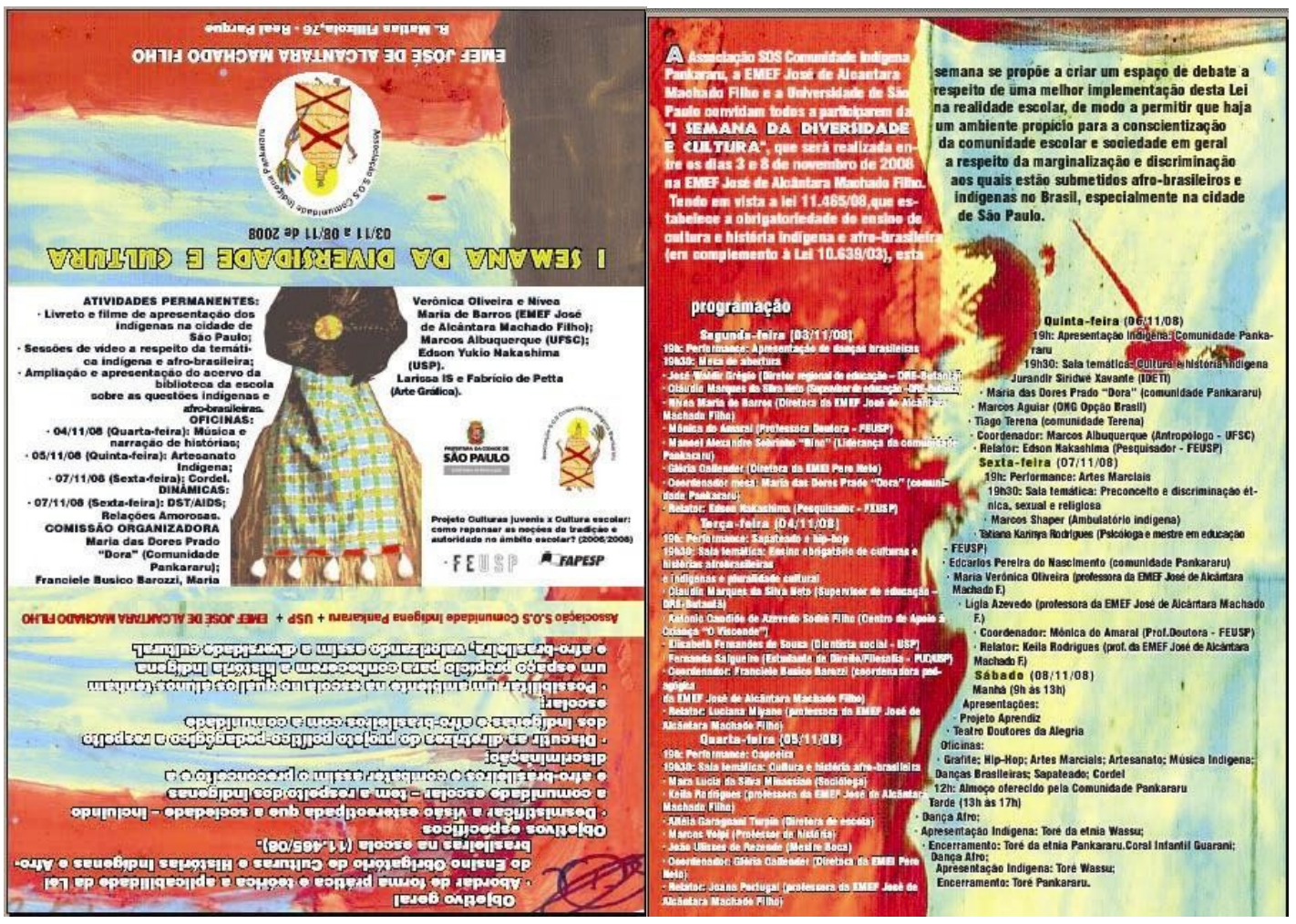




\section{Anexo III}

\section{PROGRAMAÇÃO DA ESCOLA \\ I SEMANA DE DIVERSIDADE E CULTURA EMEF JOSÉ DE ALCÂNTARA MACHADO FILHO}

\begin{tabular}{|c|c|}
\hline \multicolumn{2}{|r|}{$3^{\text {a }}$ Feira - dia 04/11 } \\
\hline $\begin{array}{l}\text { Período da manhã } \\
\mathbf{8 h 0 0} \text { às } \mathbf{1 1 h 3 0}\end{array}$ & $\begin{array}{l}\text { 8H00 - 9H00 - LANCHE RÁPIDO PARA TODAS AS TURMAS } \\
\text { 9H00 - 10h00 - Sala de leitura - atividade de leitura/história com Marcos } \\
\text { para } 1^{\circ} \text {. Ano A, com professora Ivete. } \\
\text { Mesas no Pátio - Oficina de pintura em tecido com profas Joana e Giuliana } \\
\text { (e alunos de Ensino Fundamental II previamente selecionados pelas } \\
\text { professoras para auxiliá-las) para o } 5^{\circ} \text { ano A. } \\
\text { 9h00 às } 10 h 15 \text { - projeção Kiriku e a Feiticeira para } 4^{\circ} \text {. Ano A - sala de } \\
\text { vídeo. Responsáveis: professora Ester e profa. Flavia. } \\
\text { 10h15 - 11h15 - Sala de leitura - atividade de leitura/história com Marcos } \\
\text { para } 1^{\circ} \text {. ano B com professora Rosana. } \\
\text { Mesas no Pátio - Oficina de pintura em tecido com profas Joana, Gabu (e } \\
\text { alunos de Ensino Fundamental II previamente selecionados pelas } \\
\text { professoras para auxiliá-las) para o } 5^{\circ} \text { ano B. } \\
\text { 10h15 às } 11 \text { h30 - projeção Kiriku e a Feiticeira para } 4^{\circ} \text {. Ano PIC - sala de } \\
\text { vídeo. Responsáveis: professora Nanci e profa. Flavia. } \\
\text { AULA NORMAL PARA DEMAIS TURMAS COM SEUS } \\
\text { RESPECTIVOS PROFESSORES }\end{array}$ \\
\hline $\begin{array}{l}\text { Período da tarde } \\
14 \mathrm{~h} 00 \text { às } 17 \mathrm{~h} 30\end{array}$ & 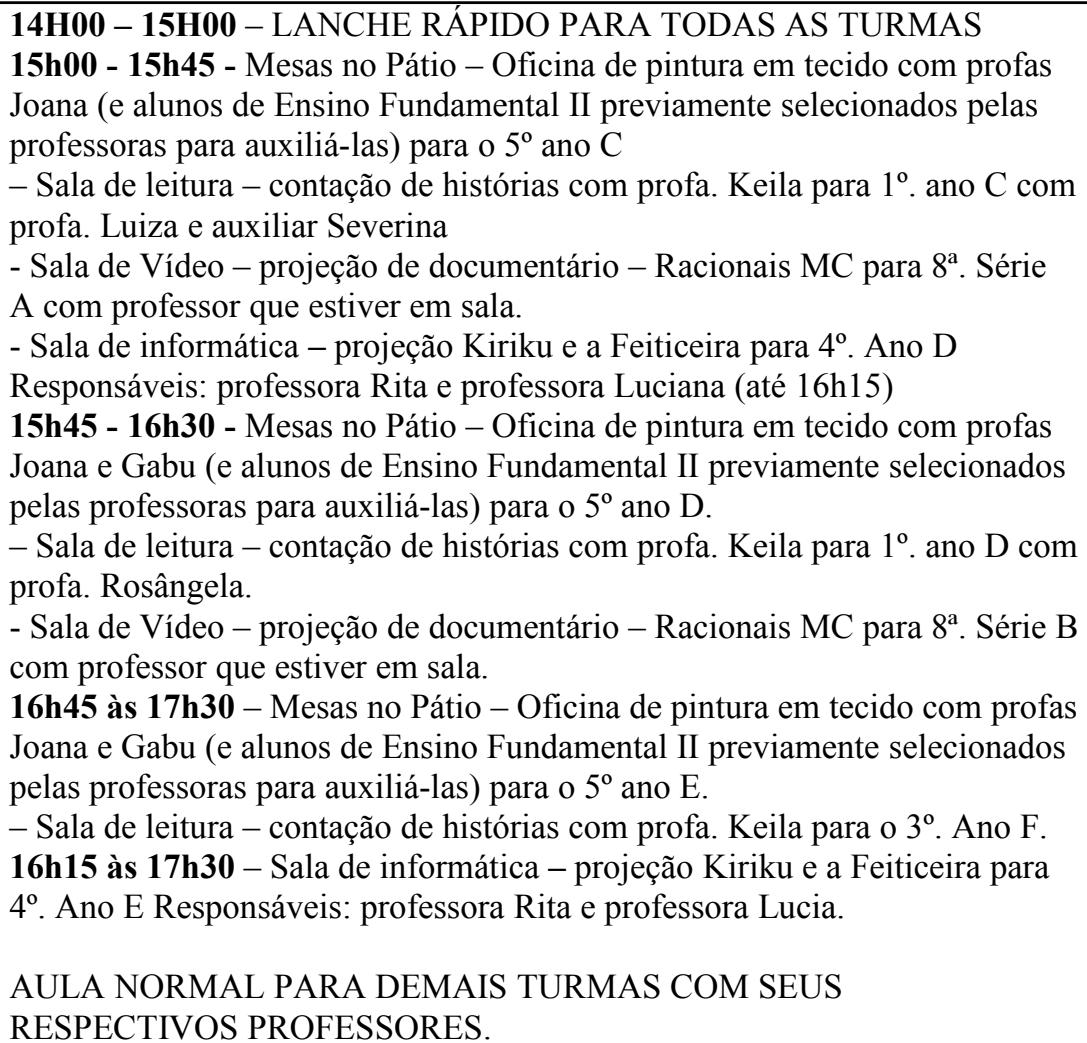 \\
\hline $\begin{array}{l}\text { Período da noite } \\
19 h 30 \text { às } 21 \text { h00 }\end{array}$ & $\begin{array}{l}\text { 19h00 - entrada - lanche rápido para os alunos do período noturno } \\
\text { 19h00 - APRESENTAÇÃO - sapateado e hip hop } \\
\text { 19h30 - Mesa: Ensino Obrigatório de Histórias e Culturas Africanas e } \\
\text { indígenas } \\
22 \mathrm{~h} 00 \text { - Encerramento }\end{array}$ \\
\hline
\end{tabular}




\section{PROVIDÊNCIAS E RESPONSABILIDADES PARA O FUNCIONAMENTO DO DIA}

1) DIREÇÃO E ASSISTENTE: pedido de lanche especial para os três períodos. Organização das turmas. Garantir liberação do uso da sala de vídeo (remanejar turma nessa semana).

2) COORDENAÇÃO E AUXILIAR DE PERÍODO: verificar funcionamento da sala de vídeo. Entregar DVD para professores responsáveis pela projeção.

3) INSPETORES DE ALUNOS; acompanhar o trânsito das turmas pelo espaço para garantir o cumprimento dos horários.

4) PROFESSORES: grupo C /JEIF deverá fazer a recepção dos convidados e controlar listas de presença até $20 \mathrm{~h} 30$.

5) ALUNOS: os assistentes das profas da oficina de pintura deverão ser dispensados de suas aulas normais para poder acompanhá-las,

6) SECRETARIA: receber os convidados que virão para a mesa de abertura - sala de JEI.

7) EQUIPE DE LIMPEZA: arrumar o pátio após os lanches da manhã eda tarde em mesas compridas para realização de oficinas de pintura de tecido. Arrumar o pátio em cadeiras enfileiradas de frente para o palco antes da entrada do noturno.

8) EQUIPE DA COZINHA: lanche rápido nos três períodos.

\begin{tabular}{|c|c|}
\hline \multicolumn{2}{|r|}{$4^{a}$. Feira - dia $05 / 11$} \\
\hline $\begin{array}{l}\text { Período da manhã } \\
\mathbf{8 h 0 0} \text { às } 11 \text { h30 }\end{array}$ & $\begin{array}{l}\text { 8H00 - 9H00 - LANCHE RÁPIDO PARA TODAS AS TURMAS } \\
\text { 9H00 - 10h00 - Sala de leitura - atividade de leitura/história com Marcos } \\
\text { para } 1^{\circ} \text {. Ano A, com professora Ivete. } \\
\text { Mesas no Pátio - Oficina de pintura em tecido com profas Joana e Giuliana } \\
\text { (e alunos de Ensino Fundamental II previamente selecionados pelas } \\
\text { professoras para auxiliá-las) para o } 5^{\circ} \text { ano A. } \\
\text { 9h00 às 10h15 - projeção Kiriku e a Feiticeira para } 4^{\circ} \text {. Ano A - sala de } \\
\text { vídeo. Responsáveis: professora Ester e profa. Flavia. } \\
\mathbf{1 0 h 1 5} \text { - 11h15 - Sala de leitura - atividade de leitura/história com Marcos } \\
\text { para } 1^{\text {o }} \text {. ano B com professora Rosana. } \\
\text { Mesas no Pátio - Oficina de pintura em tecido com profas Joana, Gabu (e } \\
\text { alunos de Ensino Fundamental II previamente selecionados pelas } \\
\text { professoras para auxiliá-las) para o } 5^{\circ} \text { ano B. } \\
\mathbf{1 0 h 1 5} \text { às } \mathbf{1 1 h 3 0} \text { - projeção Kiriku e a Feiticeira para } 4^{\circ} \text {. Ano PIC - sala de } \\
\text { vídeo. Responsáveis: professora Nanci e profa. Flavia. } \\
\text { AULA NORMAL PARA DEMAIS TURMAS COM SEUS } \\
\text { RESPECTIVOS PROFESSORES }\end{array}$ \\
\hline $\begin{array}{l}\text { Período da tarde } \\
14 \text { h00 às } 17 \text { h30 }\end{array}$ & $\begin{array}{l}\text { 14H00 - 15H00 - LANCHE RÁPIDO PARA TODAS AS TURMAS } \\
\mathbf{1 5 h 0 0} \text { - 15h45 - Mesas no Pátio - Oficina de pintura em tecido com profas } \\
\text { Joana (e alunos de Ensino Fundamental II previamente selecionados pelas } \\
\text { professoras para auxiliá-las) para o } 5^{\circ} \text { ano C } \\
\text { - Sala de leitura - contação de histórias com profa. Keila para } 1^{\circ} \text {. ano C com } \\
\text { profa. Luiza e auxiliar Severina } \\
\text { - Sala de Vídeo - projeção de documentário - Racionais MC para } 8^{\text {a }} \text {. Série } \\
\text { A com professor que estiver em sala. } \\
\text { - Sala de informática - projeção Kiriku e a Feiticeira para } 4^{\circ} \text {. Ano D } \\
\text { Responsáveis: professora Rita e professora Luciana (até } 16 \text { h15) } \\
\mathbf{1 5 h 4 5} \text { - 16h30 - Mesas no Pátio - Oficina de pintura em tecido com profas } \\
\text { Joana e Gabu (e alunos de Ensino Fundamental II previamente selecionados } \\
\text { pelas professoras para auxiliá-las) para o } 5^{\circ} \text { ano D. } \\
\text { - Sala de leitura - contação de histórias com profa. Keila para } 1^{\circ} \text {. ano D com } \\
\text { profa. Rosângela. } \\
\text { - Sala de Vídeo - projeção de documentário - Racionais MC para } 8^{\text {a }} \text {. Série B } \\
\text { com professor que estiver em sala. } \\
\mathbf{1 6 h 4 5} \text { às } \mathbf{1 7 h 3 0} \text { - Mesas no Pátio - Oficina de pintura em tecido com profas } \\
\text { Joana e Gabu (e alunos de Ensino Fundamental II previamente selecionados } \\
\text { pelas professoras para auxiliá-las) para o } 5^{\circ} \text { ano E. } \\
\text { - Sala de leitura - contação de histórias com profa. Keila para o } 3^{\circ} \text {. Ano F. } \\
\mathbf{1 6 h 1 5} \text { às } \mathbf{1 7 h 3 0} \text { - Sala de informática - projeção Kiriku e a Feiticeira para }\end{array}$ \\
\hline
\end{tabular}




\begin{tabular}{|l|l|}
\hline & $4^{\circ}$. Ano E Responsáveis: professora Rita e professora Lucia. \\
& AULA NORMAL PARA DEMAIS TURMAS COM SEUS \\
& RESPECTIVOS PROFESSORES. \\
\hline Período da noite & $19 \mathrm{~h} 00$ - entrada - lanche rápido para os alunos do período noturno \\
$\mathbf{1 9 h 3 0}$ às 21h00 & $19 \mathrm{~h} 00$ - APRESENTAÇÃO - Capoeira \\
& $19 \mathrm{~h} 30$ - Mesa: Cultura e História afro-brasileira \\
& $22 \mathrm{~h} 00$ - Encerramento \\
\hline
\end{tabular}

\begin{tabular}{|c|c|}
\hline \multicolumn{2}{|r|}{$5^{a}$. Feira - dia 06/11 } \\
\hline $\begin{array}{l}\text { Período da manhã } \\
\text { 8h00 às } 11 \text { h30 }\end{array}$ & $\begin{array}{l}\text { 8H00 - 9H00 - LANCHE RÁPIDO PARA TODAS AS TURMAS } \\
\text { 9h00 às 10h00 } \\
\text { Projeção "Viva a Diferença" para } 7^{\circ} \text {. Ano A - com profa. Ana Lucia - sala } \\
\text { de informática. } \\
\text { Projeção “"Das crianças Ikpeng para o mundo" e discussão com Edson - } \\
\text { para o 6. Ano C na sala de vídeo. } \\
\mathbf{1 0 h 4 5} \text { às 11h00 - apresentação de dança -alunos do Grêmio } \\
\text { Apresentação de Teatro - A família Faveláfrica - autoria: Gato Preto. } \\
\text { Encenação: alunos do Grêmio Escolar. PARA ALUNOS DO ENSINO } \\
\text { FUNDAMENTAL I } \\
\text { AULA NORMAL PARA DEMAIS TURMAS COM SEUS } \\
\text { RESPECTIVOS PROFESSORES }\end{array}$ \\
\hline $\begin{array}{l}\text { Período da tarde } \\
\mathbf{1 4 h 0 0} \text { às } 17 \mathrm{~h} 30\end{array}$ & $\begin{array}{l}\mathbf{1 4 H 0 0} \text { - 15H00 - LANCHE RÁPIDO PARA TODAS AS TURMAS } \\
\mathbf{1 5 h 0 0} \text { às } \mathbf{1 6 h 0 0} \\
\text { Projeção "Viva a Diferença”" para } 8^{\circ} \text {. Ano A - com profa. Rita - sala de } \\
\text { informática. } \\
\text { Projeção ““"Das crianças Ikpeng para o mundo" e discussão com Edson - } \\
\text { para o } 7^{\circ} \text {. Ano C na sala de vídeo. } \\
\mathbf{1 5 h 0 0} \text { às 16h30 - Oficina de bonecos de sucata com professora Gabu (e } \\
\text { alunos de Ensino Fundamental II previamente selecionados pela professora } \\
\text { para auxiliá-la) para o } 3^{\circ} \text {. Ano D e } 3^{\circ} \text {. Ano E acompanhados das professoras } \\
\text { Maria Rodrigues e Luciene. Local: refeitório } \\
\mathbf{1 5 h 0 0} \text { às } \mathbf{1 6 h 3 0} \text { - Oficina de artesanato indígena - com Dora Pankararu e } \\
\text { 2as, séries C e D com professoras Flavia e Thais - local quadra } \\
\mathbf{1 6 h 3 0} \text { - Roda de capoeira (alunos da } 5^{\text {a }} \text {. D e E) com profa. Mídia na quadra } \\
\text { PARA ALUNOS DO ENSINO FUNDAMENTAL I } \\
\mathbf{1 6 h 4 5} \text { às } \mathbf{1 7 h 3 0} \text { - apresentação de dança - alunos do Grêmio } \\
\text { Apresentação de Teatro - A família Faveláfrica - autoria: Gato Preto. } \\
\text { Encenação: alunos do Grêmio Escolar. PARA ALUNOS DO ENSINO } \\
\text { FUNDAMENTAL I } \\
\text { AULA NORMAL PARA DEMAIS TURMAS COM SEUS } \\
\text { RESPECTIVOS PROFESSORES. }\end{array}$ \\
\hline $\begin{array}{l}\text { Período da noite } \\
19 \text { h30 às } 21 \text { h00 }\end{array}$ & $\begin{array}{l}\text { 19h00 - entrada - lanche rápido para os alunos do período noturno } \\
\text { 19h00 - APRESENTAÇÃO - comunidade Pankararu } \\
\text { 19h30 - Mesa: Cultura e História indígena } \\
\text { 22h00 - Encerramento }\end{array}$ \\
\hline
\end{tabular}

\begin{tabular}{|c|c|}
\hline \multicolumn{2}{|r|}{$6^{a}$. Feira - dia 07/11 } \\
\hline $\begin{array}{l}\text { Período da manhã } \\
\mathbf{8 h 0 0} \text { às } 11 \text { h30 }\end{array}$ & $\begin{array}{l}\text { 8H00 - 9H00 - LANCHE RÁPIDO PARA TODAS AS TURMAS } \\
\text { 9h00 às } 10 \text { h15 } \\
\text { Projeção "Viva a Diferença" para } 6 \text {. Ano B - com profa. Ana - sala de } \\
\text { informática. } \\
\mathbf{1 0 h 4 5} \text { às } 11 \text { h00 - apresentação de dança - alunos do Grêmio } \\
\text { Apresentação de Teatro - A família Faveláfrica - autoria: Gato Preto. } \\
\text { Encenação: alunos do Grêmio Escolar. PARA ALUNOS DO ENSINO } \\
\text { FUNDAMENTAL II } \\
\text { AULA NORMAL PARA DEMAIS TURMAS COM SEUS } \\
\text { RESPECTIVOS PROFESSORES }\end{array}$ \\
\hline Período da tarde & 14H00 - 15H00 - LANCHE RÁPIDO PARA TODAS AS TURMAS \\
\hline
\end{tabular}




\begin{tabular}{|c|l|}
\hline $\mathbf{1 4 h 0 0}$ às 17h30 & $\begin{array}{l}\mathbf{1 5 h 0 0} \text { às 16h15 } \\
\text { Dinâmica: "Relações amorosas" com Tatiana Karinya Rodrigues - para o } 6^{\circ} . \\
\text { Ano D e E na sala de vídeo. } \\
\text { Projeção "Viva a Diferença" para } 8^{\circ} \text {. Ano B - com profa. Rita - sala de } \\
\text { informática. } \\
\mathbf{1 6 h 4 5} \text { às 17h30 - apresentação de dança -alunos do Grêmio } \\
\text { Apresentação de Teatro - A família Faveláfrica - autoria: Gato Preto. } \\
\text { Encenação: alunos do Grêmio Escolar. PARA ALUNOS DO ENSINO } \\
\text { FUNDAMENTAL II } \\
\text { AULA NORMAL PARA DEMAIS TURMAS COM SEUS } \\
\text { RESPECTIVOS PROFESSORES }\end{array}$ \\
\hline $\begin{array}{l}\text { Período da noite } \\
\mathbf{1 9 h 3 0} \text { às 21h00 }\end{array}$ & $\begin{array}{l}19 \mathrm{~h} 00 \text { - entrada - lanche rápido para os alunos do período noturno } \\
19 \mathrm{~h} 00 \text { - APRESENTAÇÃO - artes marciais } \\
19 \mathrm{~h} 30-\text { Mesa: Preconceito e discriminação étnica, religiosa e sexual } \\
\text { 22h00 - Encerramento }\end{array}$ \\
\hline
\end{tabular}




\section{Anexo IV}

\section{Livreto "Eu venho do mundo"}
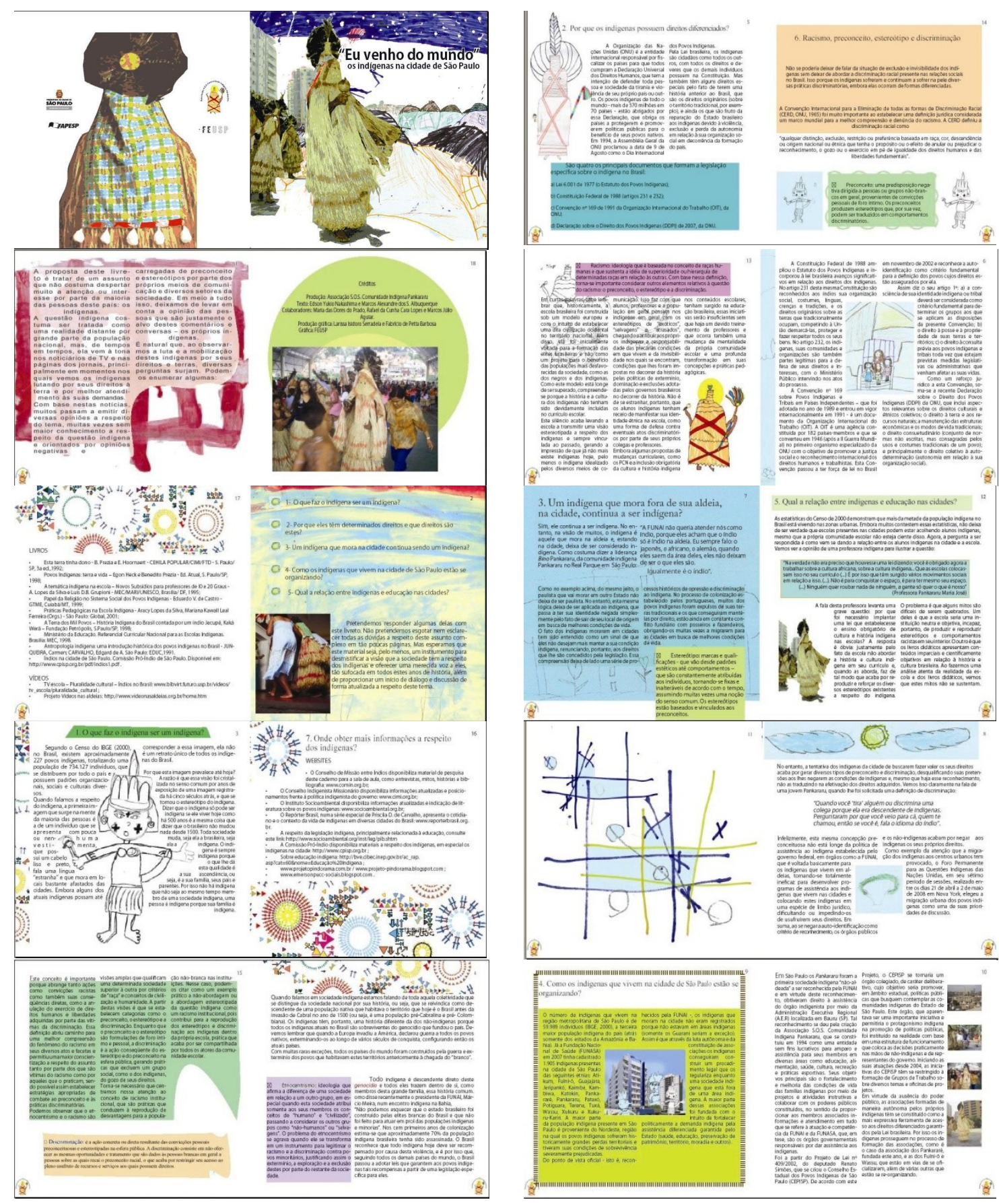

$\cos ^{m}$

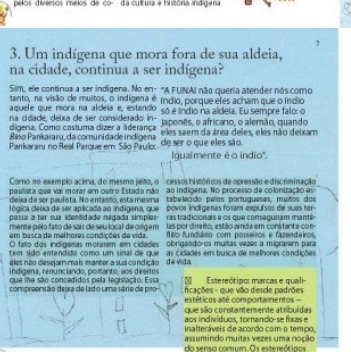

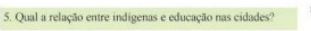

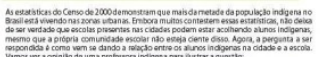
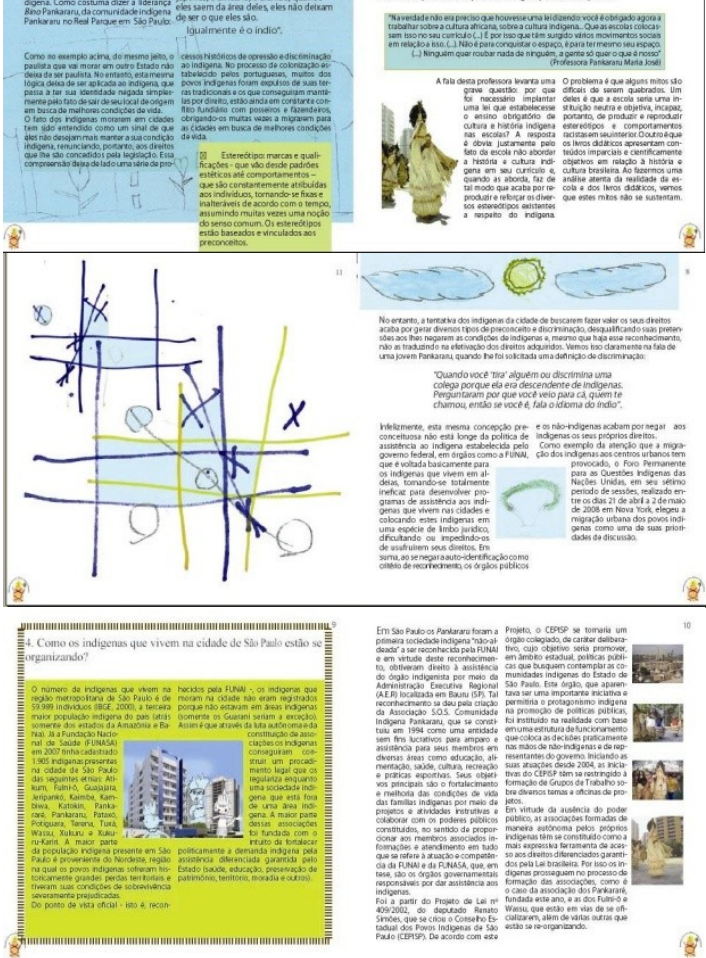


\section{Anexo $V$}

\section{Banners da Semana}
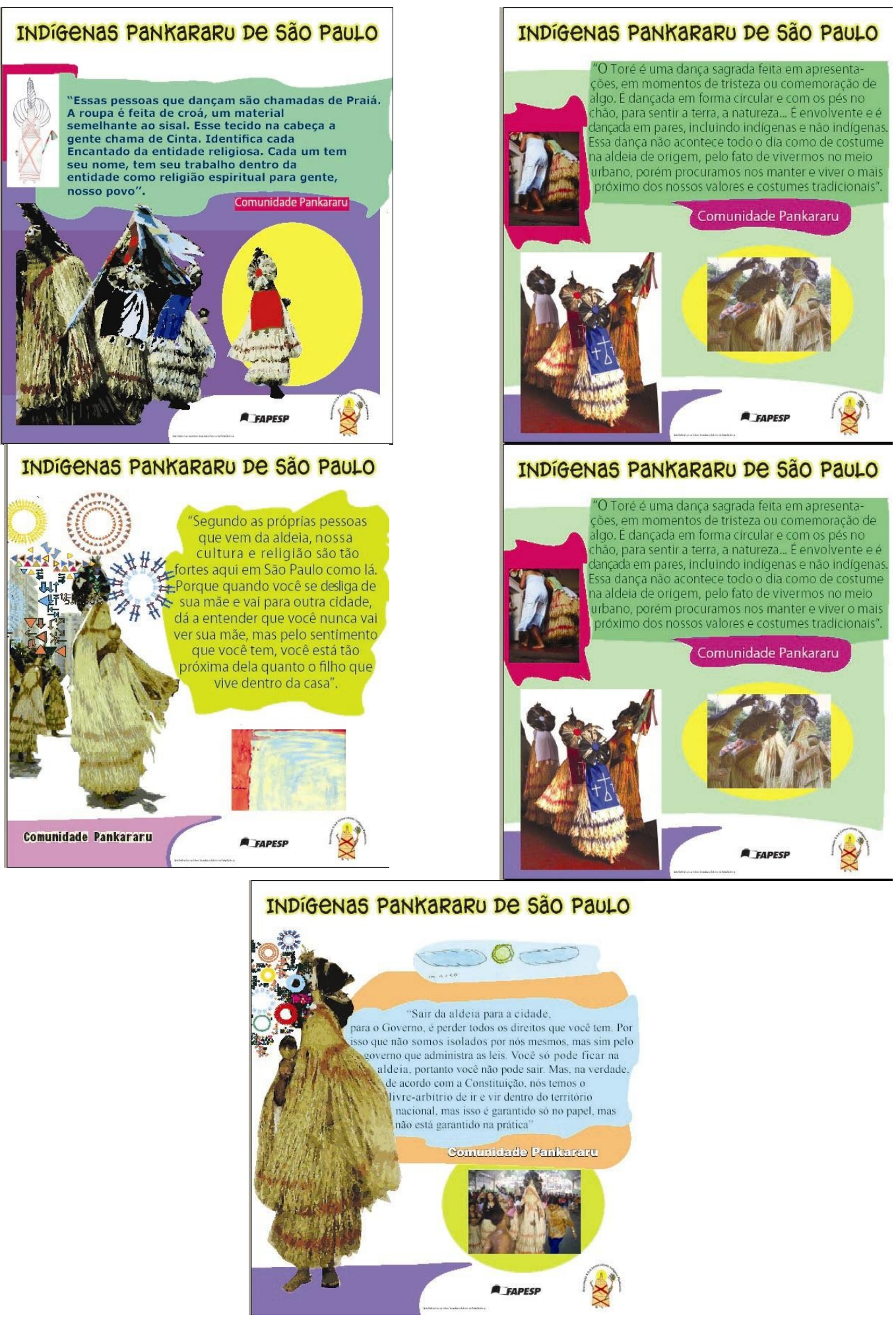


\section{Anexo VI}

\section{Vista a minha pele}

Para Júlio Hendrix Silva Rodrigues

Vista a minha pele

Você conseguiria?

Seja negro só por um dia

Seja preto pelo menos por mim

Somando todas as minhas cores assim

Vista a minha pele

Assuma a minha cor

Seja você quem for

Capture radicalmente a minha dor

Bem lá dentro de mim

E procure me compreender melhor assim

Vista a minha pele

Eu sou igualzinho a você

Ser Humano, porque

Corpo, Mente, Banzo, Coração

Então questione racismo e discriminação

Vista a minha pele

Sou vermelho por dentro

E negro sempre cem por cento

Afrobrasilis, Afro-descendente

Muito além de para sempre

Inteiramente ser humano e, sobretudo, gente

Vista a minha pele

Vista-se epidermicamente de mim

E procure me entender como seu igual assim

Seu irmão da humana cósmica raça

E sinta tudo o que dentro de mim se passa

Assim você muito bem confere

Assim você vai realmente se sentir

Lá dentro da minha própria pele

Como eu quero ser árvore de leite e florir

Como eu quero ser janela de pão e me abrir

Como eu quero ser estrada de açúcar e prosseguir

Como eu quero o fim de diásporas e sorrir

Sem nenhum branco para me ferir

E você vai captar essencialmente então

A verdadeira pureza do que é primordial

E o que eu quero é total libertação 
E todos iguais na aquarela da coloração

Numa brasileiríssima democracia racial

Vista a minha pele

Seja um pouco eu mesmo um negrão aí

Dentro de você - Para você sentir

Sou preto brasileirinho

Sou negrão e sou negrinho

Sou Negro e Ser Humano de igual valor

E tenho a África nas moendas e engenhos no meu interior

Depois de me vestir e depois de se sair de si

Deixando de ser eu negro aí

Venha me estender a sua mão

E, de coração para coração

Abrace-me como um seu completo irmão

A pele espiritual sendo uma só então

Numa sagrada e sideral celebração.

$-0-$

Silas Corrêa Leite - 
Anexo VII

I Semana de Diversidade e Cultura
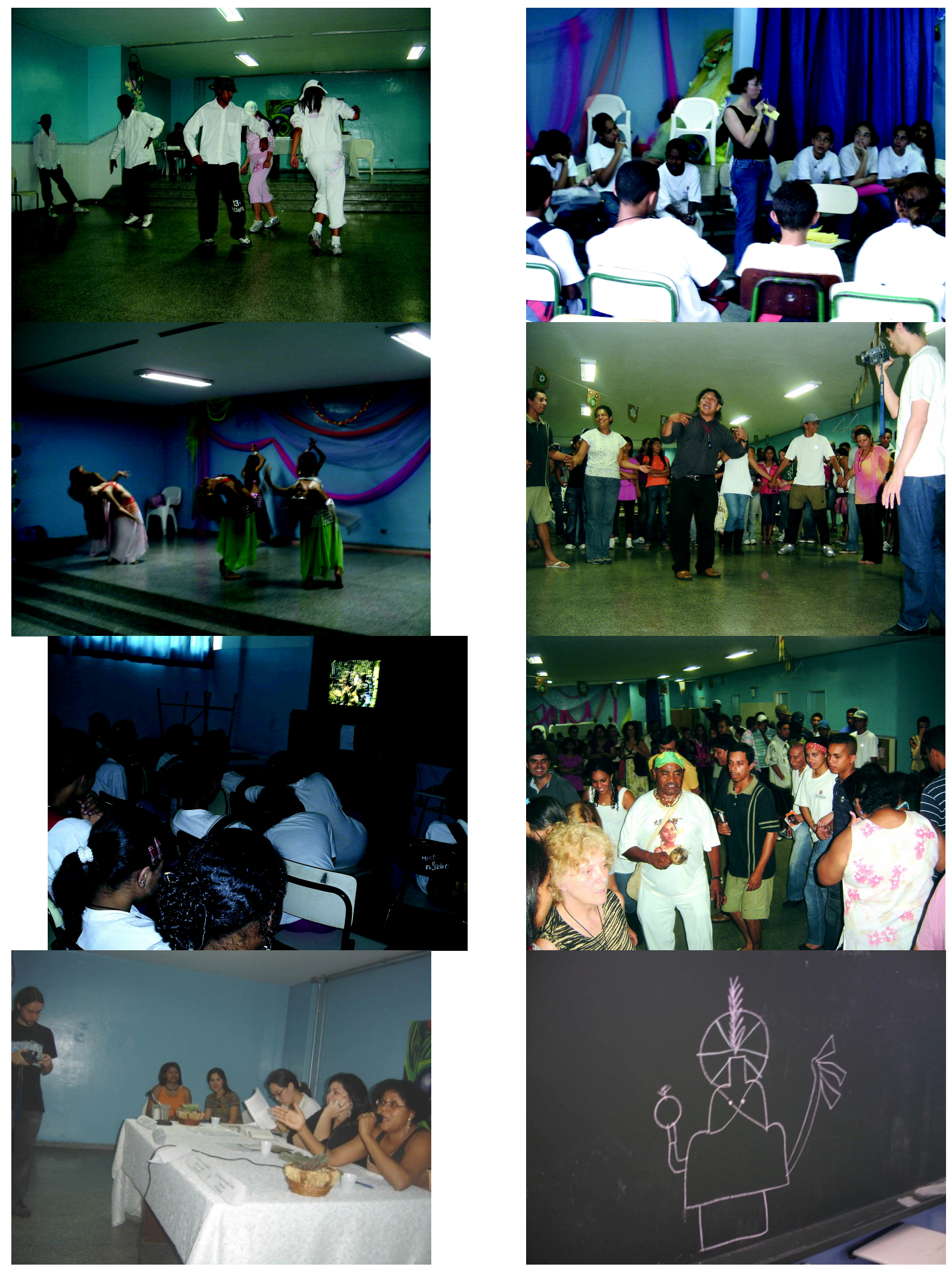

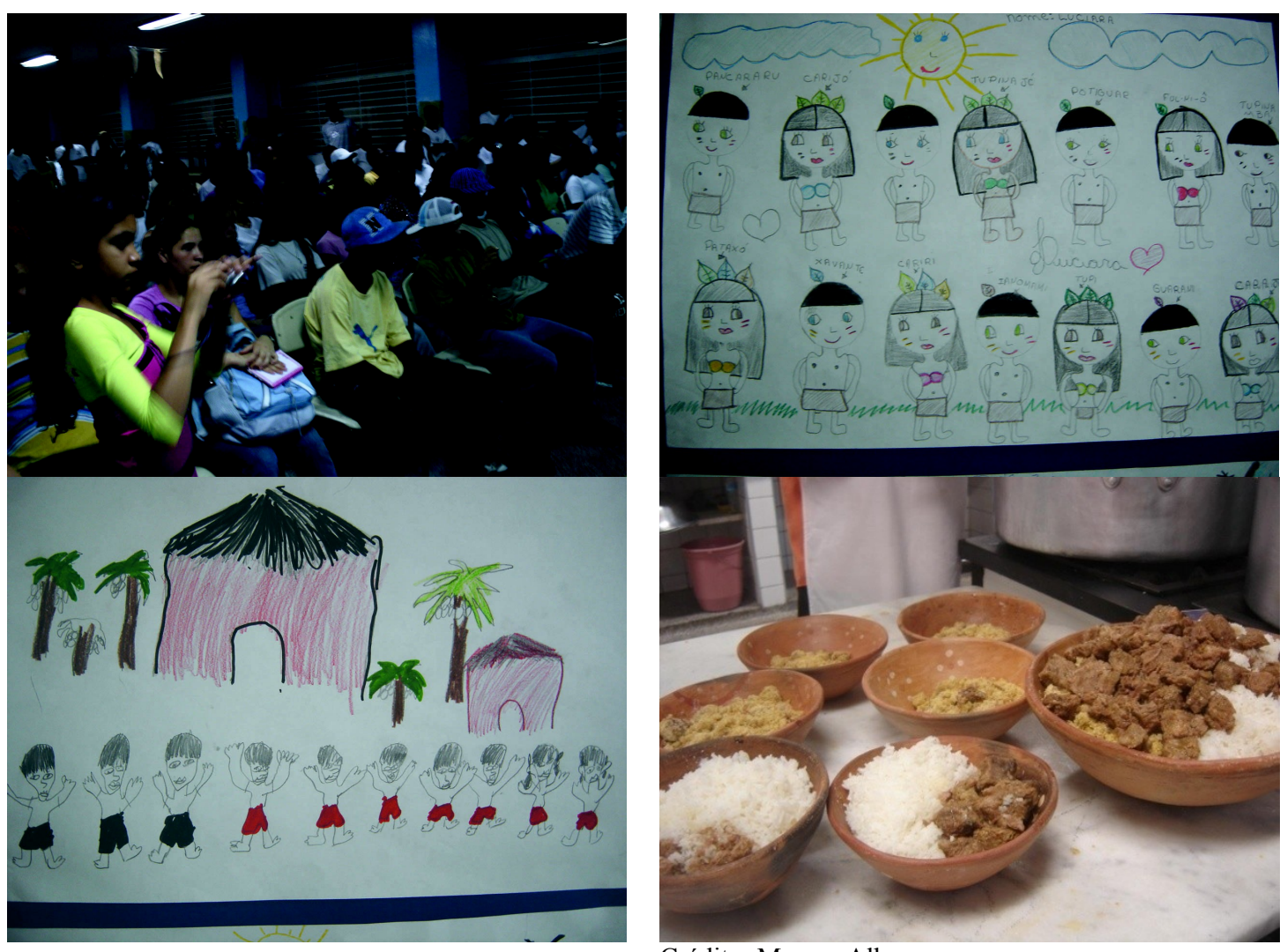

Crédito: Marcos Albuquerque

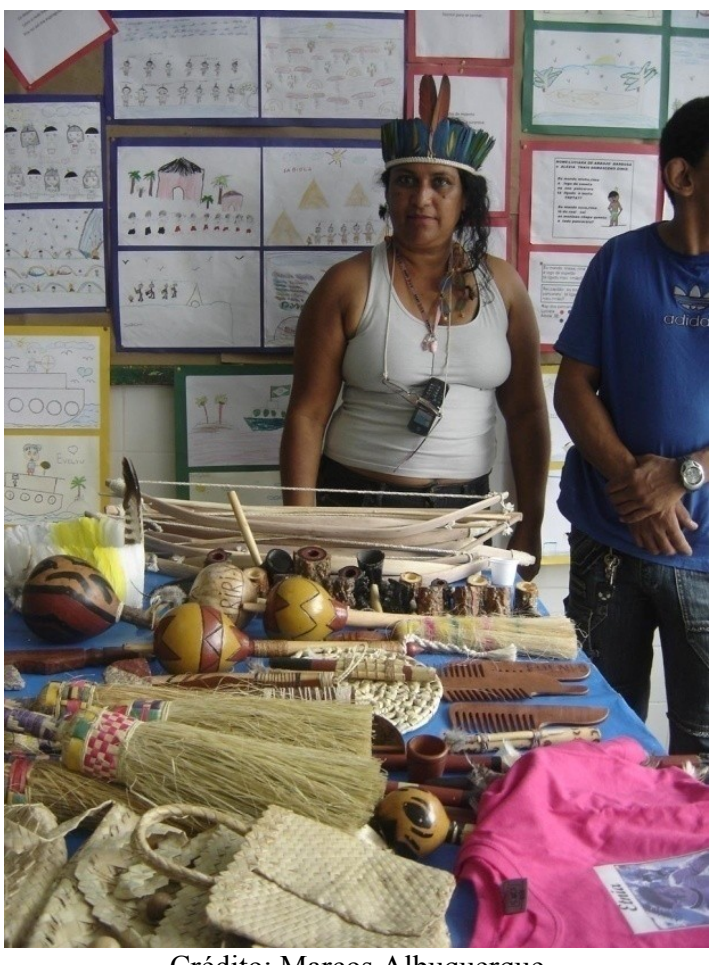

Crédito: Marcos Albuquerque 

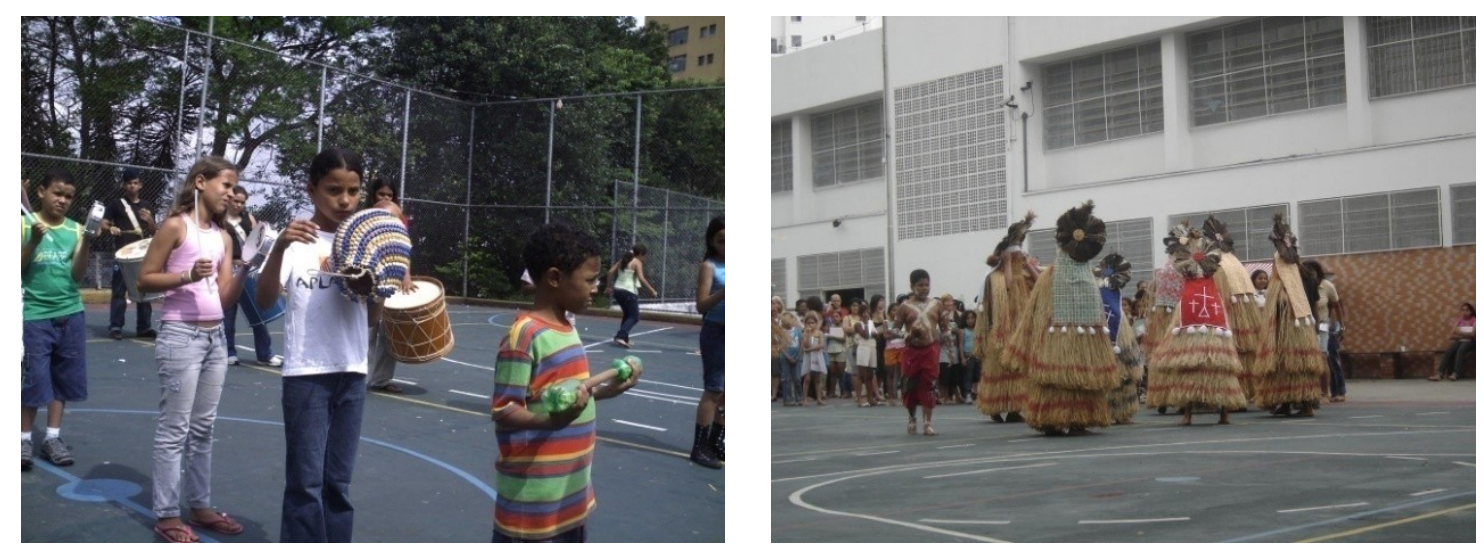

Crédito: Marcos Albuquerque
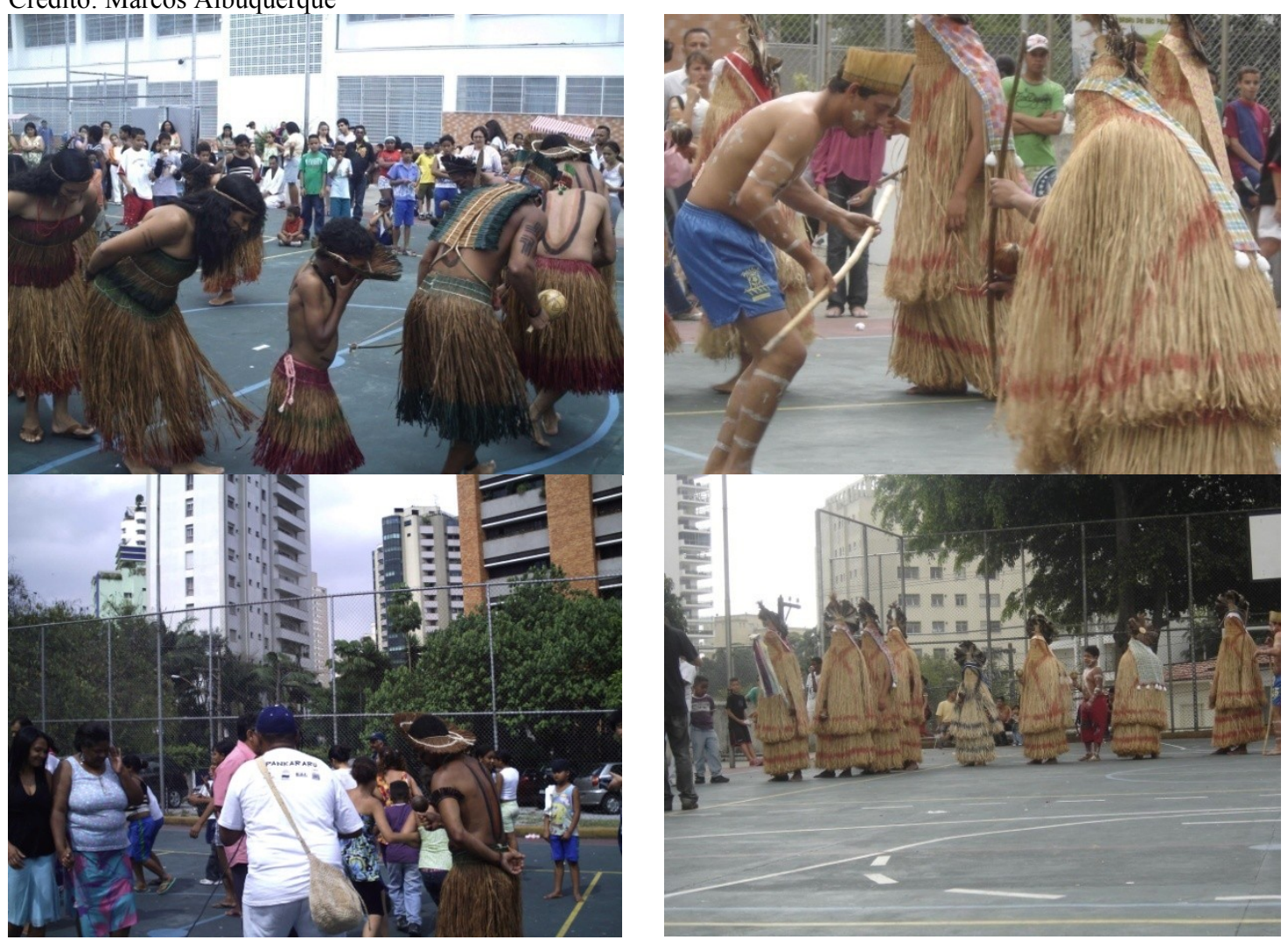


\section{Bibliografia}

ADORNO, R. C. F. ; VARGA, I. V. D. ; VASCONCELlOS, M. P. C. Povos e Comunidades Indígenas vivendo fora de terras demarcadas:desafios aos sistemas de coleta de dades e de Indicadores de Saúde. In: VI Congresso Brasileiro de Epidemiologia, 2004, Recife. Oficina de Saúde Indígena da ABRASCO, 2004.

ALBERT, B. Na Amazônia Bn: http://www.socioambiental.org/pib/portugues/org/amazo.shtm, 2000 (acessado em 21 de outubro de 2008).

ALBUQUERQUE, M. A. S. Mobilização étnica na cidade de São Paulo: o caso dos índios Pankararu. In: Espaço Ameríndio, Porto Alegre, v. 1, n. 1, p. 73-101, jul./dez. 2007.

ALBUQUERQUE, M. A. S.; NAKASHIMA, E. Eu venho do mundo. 2008 (no prelo). AMARAL, M. do, et alli. Uma etnografia do olhar em direção às culturas juvenis e étnicas: uma ruptura possível na cultura escolar? Anais da $5^{\text {a }}$ Semana da Educação da FEUSP. Site: http://www3.fe.usp.br/secoes/semana07/completos/mgt.swf (Acessado em 09 de maio de 2008). - Apresentação à Edição Brasileira. In: Novas problemáticas da adolescência: evolução e manejo da dependência. São Paulo: Casa do Psicólogo, 2005. . Culturas juvenis X cultura escolar: como repensar as noções de tradição e autoridade no âmbito da educação? Projeto de Pesquisa apresentado ao Programa "Melhoria do Ensino Público" da FAPESP - Fundação de Amparo à Pesquisa do Estado de São Paulo. São Paulo: 2006.

. Relatório Científico Parcial do Projeto de Pesquisa Culturas Juvenis X Cultura Escolar: como repensar as noções de tradição e autoridade no âmbito da educação? (FAPESP, out/2006 a setembro/2007). São Paulo: 2007.

AMARAL, M. do; ABBONDANZA, L.; LEITE, S.C.; NAKASHIMA, E.Y. Educação pública no Brasil: miopia ou hipermetropia. Jornal da USP ano XXII n.799, 23 a 29 de abril de 2007. São Paulo: USP, 2007.

ARRUTI, J. M. A. Morte e vida no Nordeste indígena: a emergência étnica como fenômeno regional. Estudos Históricos. FVG, vol.8, n.15, pp. 1-55, 1995. Acesso: http://www.cpdoc.fgv.br/revista/arq/165.pdf .

. De como a cultura se faz politica e vice-versa: Sobre religiões, 
festas, negritudes e indianidades no Nordeste contemporâneo. "IV Ciclo NAÇÃO E REGIÃO - Brasil 500 anos - Experiência e Destino" promovido pela FUNART / UERJ e UENF, 2002.

. Pankararu - povos indígenas do Brasil. Julho de 2005. In:

http://www.socioambiental.org/pib/epi/pankararu/pankararu.shtm. (acessado em 01 de junho de 2006).

ATHIAS, R. Espaço, Fecundidade e Reprodução entre os Pankararu. Trabalho apresentado no XIII Encontro da Associação Brasileira de Estudos Populacionais, realizado em Ouro Preto, Minas Gerais, Brasil de 4 a 8 de novembro de 2002.

BAINES, S. G. As chamadas 'aldeias urbanas'ou índios na cidade. Brasil Indígena, Fundação Nacional do Índio, v. 7, p. 15 - 17, 01 dez. 2001.

BARTH, F. O Guru, o Iniciador e Outras Variações Antropológicas. Org. Tomke Lask, trad. De Jonh C. Comerford. Rio de Janeiro, Contra Capa, 2000.

BEAUDET, J. “Souffles d'Amazonie”. Nanterre: Société d'ethnologie, 1997.

BENJAMIN, W. (1936). O Narrador - Considerações sobre a obra de Nikolai Leskov. In: Obras Escolhidas: Magia, Técnica, Arte e Política. São Paulo: Brasiliense, 1985.

BONIN, I.T.. E por falar em povos indígenas... uma conversa sobre práticas pedagógicas que ensinam sobre identidades e diferenças. In: 30 Reunião Anual da Anped, 2007, Caxambu/MG. 30 ${ }^{\mathrm{a}}$ Reunião Anual da Associação nacional de PósGraduação e Pesquisa em Educação, 2007.

BOURDIEU, Pierre. O poder simbólico. Rio de Janeiro: Bertrand Brasil, 1989

BOURDIEU, P. \& PASSERON, C. A reprodução: elementos para uma teoria do sistema de ensino. Rio de Janeiro: Francisco Alves, 1975.

BOWLES, S. \& GINTIS, H. A educação como campo de contradições na reprodução da relação capital-trabalho: reflexões sobre o princípio da correspondência. Teoria \& Educação, Porto Alegre: Palmarinca, n. 1, 1990.

BRASIL. Educação Escolar Indígena. MEC/SECAD. http://portal.mec.gov.br/secad. (acessado em 28 de maio de 2008).

BRASIL. Ensino médio e sustentabilidade em terras indígenas. Boletim 5. Ministério da Educação. Brasília: SEED/MEC, 2007.

BRASIL. Guia de livros didáticos PNLD 2008: apresentação / Ministério da Educação. Brasília: MEC, 2007.

BRASIL. Guia de Livros Didáticos PNLD 2005. Ministério da Educação. Brasília: MEC, 2005. 
BRASIL. IBGE. Tendências Demográficas: uma análise dos indigenas com base nos resultados da amostra dos censos demográficos 1991 a 2000. Rio de Janeiro, 2005.

BRASIL. Ministério da Educação. Plano decenal de educação para todos. Brasília, 1993.

BRASIL. Ministério da Educação. Secretaria de Educação Fundamental. Parâmetros curriculares nacionais: temas transversais. Brasília, 1998.

BRASIL. Referencial Curricular Nacional para as Escolas Indígenas. Brasília: MEC, 1998.

BURITY, J. Um novo espaço público entre os pobres? Identidade coletiva $e$ associativismo local no Nordeste brasileiro. In: CAVALCANTI, Helenilda e BURITY, J. (orgs.) Polifonia da miséria: uma construção de novos olhares. Recife,Fundação Joaquim Nabuco, 2002.

BUSQUETS, M. D. et alii. Temas transversais em educação - bases para uma formação integral. São Paulo: Ática, 1998.

CANDAU, V. M. F. (org.). Reinventar a escola. Petrópolis: Vozes, 2000. Educação Intercultural no contexto brasileiro: questões e desafios.

In: II Seminário Internacional Educação, Intercultural, Gênero e Movimentos Sociais, 2003, Florianópolis. Identidade, Diferenças e Mediações, 2003.

CANEN, A. Educação multicultural, identidade nacional e pluralidade cultural tensões e implicações curriculares. Cadernos de Pesquisa, nº 111, Dezembro de 2000.

CANEVACCI, M. Diversidade nômade e a mutação cultural. In: TRINDADE, Azoilda e SANTOS Rafael (orgs.). Multiculturalismo: as mil e uma faces da escola. DP\&A Editora. Rio de Janeiro, 2000. . Eróptica: etnografia palpitante para um olhar díspar. Revista IDE, Sociedade Brasileira de Psicanálise de São Paulo, v.41, julho de 2005 b.

CARDOSO DE OLIVEIRA, R. Caminhos da identidade - ensaios sobre etnicidade e multiculturalismo. São Paulo: Editora Unesp; Brasília: Paralelo 15, 2006.

Identidade étnica, identificação e manipulação.

Universidade Federal de Goiás. Goiânia: Sociedade e cultura. 2003. . Identidade, etnia e estrutura social. São Paulo: Pioneira, 1976. O índio e o mundo dos brancos. Campinas: Editora da Unicamp, 1996. 
O processo de assimilação dos Têrena. Rio de Janeiro:

Coleção Museu Nacional, 1960.

CARNEIRO DA CUNHA, M. Performance e prática nos cerimoniais Pankararu. In: Povos indígenas de Pernambuco: identidade, diversidade e conflito / organizador Renato Athias. - Recife: Ed. Universitária da UFPE, 2007. . Ritos e festa pankararu: uma etnografia da musica.

In: XII Encontro Nacional da ANPPOM, Salvador, 1999. . A Música Encantada Pankararu (toantes, toré, ritos

e festas na cultura dos índios Pankararu). Dissertação (Mestrado em Antropologia Cultural), Recife: UFPE, 1999.

CARTA DA MOBILIZAÇÃO NACIONAL TERRA LIVRE. Abril Indígena. 2006.

CASTRO, K. C.; MARSICO, M. T. ; CUNHA, M. C. T.; ANTUNES, M.E.M; NETO, A.C.C. Coleção Caracol: história: $4^{a}$ série. São Paulo: Scipione, 2004.

CERTEAU, M. A cultura no plural. São Paulo: Papirus, 1995.

CERVONE, E. Los desafios de la etnicidad: las luchas del movimiento indigena en la modernidad. Journal of Latin American Anthropology 4(1): 46-73 46, 1999.

CHNAIDERMAN, M. Racismo, o Estranhamente Familiar: uma Abordagem Psicanalítica. In: L. Schwartz \& R. S. Queiroz (orgs), Raça e Diversidade. São Paulo: Edusp, 1996.

COHN, C. Culturas em transformação: os índios e a civilização. São Paulo em Perspec., São Paulo, v. 15, n. 2, 2001.

COMISSÃO DE DIREITOS HUMANOS DA ASSEMBLÉIA LEGISLATIVA DO ESTADO DE SÃO PAULO. Vamos Ouvir a Voz dos que Não tem Vez: Relatório das Audiências Públicas sobre a Situação dos Povos Indígenas no Estado de São Paulo. São Paulo: Publicação do mandato do Deputado Estadual Renato Simões (PT/SP), 2002.

COMISSÃO PRÓ-ÍNDIO DE SÃO PAULO. Índios na Cidade de São Paulo. Organização de Selma Gomes. Relatório da Comissão Pró-Índio de São Paulo. São Paulo, 2005.

COSSO, R. Alckmin faz ocas em reservas indigenas. Folha de São Paulo, São Paulo, 23 jun. 2002.

CUNHA, M. C. Antropologia do Brasil. 2 ed. São Paulo: Brasiliense, 1987.

Dic. Aurélio Básico da L. Portuguesa / Aurélio B. de Holanda Ferreira - Rio de Janeiro: Nova Fronteira, 1995. 
ERIKSON, E. H. Identidade, juventude e crise. Rio de Janeiro, Zahar, 1970.

FIALHO, V. Associativismo, desenvolvimento e a configuração da Mobilização Indígena no Nordeste Brasileiro. In: Renato Athias. (Org.). Povos Indígenas de Pernambuco: identidade, diversidade e conflito. Recife/PE: Editora Universitária UFPE, 2008 .

FIX, M. O Estado e o capital nas margens do Rio Pinheiros - duas intervenções: Faria Lima e Água Espraiada. Trabalho de Graduação Interdisciplinar, Faculdade de Arquitetura e Urbanismo da Universidade de São Paulo, 1996.

FREUD, S. El malestar em la cultura (1930/29). Obras completas. Vol. XXI. Buenos Aires, Amorrortu Editores, 2001.

. Moisés y la religión monoteísta (1939). Obras completas. Vol. XXIII. Buenos Aires, Amorrortu Editores, 2001.

FURUI, V.; Capuchinho, C. Real Parque: a história dos indesejados. In: http://carosamigos.terra.com.br/nova/ed131/materia_cristiane.asp. (acessado em: $01 / 11 / 2008)$.

GIROUX, H. A. Escola crítica e política cultural. Coleção Polêmicas do Nosso Tempo, 20. São Paulo: Cortez Editora, 1988. . Pedagogia radical. São Paulo: Cortez Editora, 1983. .Praticando Estudos Culturais nas Faculdades de Educação. In: Silva, T. T. (org) Alienígenas na sala de aula. Porto Alegre: Artes Médicas, 1995.

GOBBI, I. A temática indígena e a diversidade cultural nos livros didáticos de história: uma análise dos livros recomendados pelo Programa Nacional do Livro Didático. Dissertação de mestrado em Ciências Sociais. UFSCar, 2006.

GOODMAN, M. E. Race Awareness in Young Children. New York: Collier Books, 1964. $<$ http://books.google.com/books?id=FINHAAAAMAAJ>.

GRAMSCI, A. Os intelectuais e a organização da cultura. Rio de Janeiro: Civilização Brasileira, 1968.

GRUNEWALD, R. A. O 'Índio' da Serra do Umã: etnicidade e faccionalismo. [s.1.]: (s.n.), 1995.

GRUPIONI, L.D.B. Introdução. Educação Escolar Indígena. In: http://pib.socioambiental.org/pt/c/politicas-indigenistas/educacao-escolarindigena/introducao. (acessado em 08/12/2008).

Trajetória de uma política pública: o governo federal e a educação indígena no Brasil. In: www.institutoiepe.org.br . (acessado em 08/12/2008). 
HALL, S. Da diáspora: identidades e mediações culturais. Belo Horizonte: Editora UFMG; Brasília: Representação da Unesco no Brasil, 2003.

HANNERZ, U. Fluxos, fronteiras, hibridos: Palavras-chave da antropologia transnacional. Mana 3 (1), 1997.

HOBSBAWM, E. J. Introdução: a invenção das tradições. In: HOBSBAWM, Eric; RANGER, T. A invenção das tradições. Rio de Janeiro: Paz e Terra; 1984.

HOHENTHAL JR., W.D. "As tribos indígenas do médio e baixo São Francisco". In: Revista do Museu Paulista, Nova Série, 12: 37-71, 1960.

IGLECIAS, W. Impactos da mundialização sobre uma metrópole periférica. Rev. bras. Ci. Soc. , São Paulo, v. 17, n. 50, 2002. Disponível em: $<$ http://www.scielo.br/scielo.php?

script $=$ sci_arttext\&pid $=\mathrm{S} 0102-69092002000300004 \& \operatorname{lng}=\& \mathrm{nrm}=\mathrm{iso}>$. Acesso em: 20 2008. doi: 10.1590/S0102-69092002000300004.

INEP. Estatísticas sobre educação escolar indígena no Brasil - Brasília: Instituto Nacional de Estudos e Pesquisas Educacionais, 2007.

JEAMMET, P.; CORCOS, M. Novas problemáticas da adolescência: evolução e manejo da dependência. São Paulo: Casa do Psicólogo, 2005.

LÉNCLUD, G. « La tradition n'est plus ce qu'elle était... », Terrain, Numéro 9 - Habiter la Maison (octobre 1987), [En ligne], mis en ligne le 21 juillet 2005. URL : http://terrain.revues.org/document3195.html. Acessado em 2 de setembro de 2006.

LIMA, C. L. S. Vivendo na metropóle: os Pankararu em São Paulo. In: 26 REUNIÃO BRASILEIRA DE ANTROPOLOGIA, 2008, Porto Seguro. Desigualdade na diversidade. Brasília: ABA, 2008.

LOPES DA SILVA, A. Educação para a Tolerância e Povos Indígenas no Brasil. In: GRUPIONI, Luís Donizete Benzi; VIDAL, Lux Boelitz \& FISCHMANN, Roseli (org.). Povos Indígenas e Tolerância: construindo práticas de respeito e solidariedade. São Paulo: Edusp, 2001.

HORKHEIMER, Max. Eclipse da razão. Rio de Janeiro: Labor, 1976.

LOPES DA SILVA, A. Novos tempos, velhas histórias. Revista Brasileira de Ciências Sociais. Vol. 14, nº 40. São Paulo: 1999.

MATTA, P. Dois Elos da Mesma Corrente: Uma Etnografia da Corrida do Umbu e da Penitência entre os Pankararu. Dissertação (Mestrado em Antropologia Social), São Paulo: USP, 2005.

MAURO, V. F. Breves considerações acerca das atuais condições de vida do povo 
Pankararu. Revista de Estudos e Pesquisas. Brasília: FUNAI: CGEP/CDGTI, v.4, n.1, 2007.

MEDEIROS, M. Mantendo as Raízes. Revista do Terceiro Setor, São Paulo, 2004.

MILNITSKY-SAPIRO, C. Uma questão de método. (mimeo, 2006).

MORENO, M. Temas transversais: um ensino voltado para o futuro. In: BUSQUETS, M. D. e. o. Temas transversais em educação: bases para uma formação integral. São Paulo: Ática, 1998.

NASCIMENTO, R. H. Z. Aspectos musicais no Toré Fulni-ô: evidenciando a identidade étnica. Salvador. Dissertação de Mestrado, UFBA, 1998

NOVAES, S. C. Jogo de espelhos: imagens da representação de si através dos outros. São Paulo: EDUSP, 1993.

OLIVEIRA FILHO, J. P. In: A viagem de volta: etnicidade, política e reelaboração cultural no Nordeste indígena. Rio de Janeiro: Contra Capa Livraria, 1999. . O nosso governo: os ticuna e o regime tutelar. São Paulo:

Marco Zero; 1988.

- Os povos indígenas no Nordeste: fronteiras étnicas e identidades emergentes. Republicado como: Fronteiras étnicas e identidades emergentes. In: Povos Indígenas no Brasil 1991/95. São Paulo: Instituto Sócio Ambiental - ISA, 1996 (Cadernos). - Prefácio. In: Toré: Regime Encantado dos Índio do Nordeste. Recife: Editora Massangana, 2005.

. Três teses equivocadas sobre o indigenismo (em especial sobre os índios do Nordeste). In: M. A. Espírito Santo (org.). Política indigenista no Leste e Nordeste brasileiro. Brasília: Funai; 2000.

. Uma etnologia dos 'índios misturados'? Situação colonial, territorialização e fluxos culturais. MANA - Estudo de Antropologia Social, Rio de Janeiro, v.4, n. 1, p. 47-77, abr., 1998.

Cidadania, Racismo e Pluralismo: a presença das sociedades indígenas na organização do Estado-Nacional brasileiro. Em: Ensaios em Antropologia Histórica. Rio de Janeiro: Editora UFRJ. 1999.

OLIVEIRA, G. A. Torém: a brincadeira dos índios velhos. São Paulo: Annablume: Fortaleza: Secretaria da Cultura e Desportos, 1997.

OSSAMI DE MOURA, M. C. Discriminação estrutural, institucional e sistêmica Povos Indígenas. Anais de Seminários Regionais Preparatórios para Conferência 
Mundial contra o Racismo, discriminação, xenofobia e intolerância correlata. Brasília, v. 1, 2001.

RAMOS PANKARARU, E. U. Experiências exemplares de oferta de Ensino Médio em escolas indígenas: o caso da escola Pankararu . In: Salto para o futuro. Ensino médio e sustentabilidade em terras indígenas. Brasília: SEED-MEC, B. 5, 2007.

PEREIRA, D. M. D. B. O estado pluriétnico. In: Além da tutela: bases para uma nova política indigenista III. Rio de Janeiro: Laced, 2002. p. 41-47. (PGR).

PETI - Projeto Estudo sobre Terras Indígenas no Brasil. In: Atlas das Terras Indígenas do Nordeste. Rio de Janeiro: PETI/PPGAS/Museu Nacional/UFRJ, 1993.

PIZA, E. Adolescência e racismo: uma breve reflexão. In: SIMPÓSIO INTERNACIONAL DO ADOLESCENTE, 1., 2005, São Paulo. Proceedings online... Available $\quad$ from: $\quad<$ http://www.proceedings.scielo.br/scielo.php? script $=$ sci_arttext\&pid=MSC0000000082005000100022\&lng=en\&nrm=abn $>$. Acesso em: 10 Mar. 2008.

POUILLON, J., "Tradition : transmission ou reconstruction » in J. Pouillon Fétiches sans fétichisme, Paris, Maspero, 1975.

PREZIA, B. Projeto Pindorama forma universitários indigenas em São Paulo. Brasília, Porantim, XXVIII, no 292, jan/fev, 2007, p. 7.

RIBEIRO, G. L. Cultura, derechos humanos y poder. Más allá del imperio de los derechos humanos. Por un universalismo heteroglóxico. “.En Materiales de enseñanza de Multiculturalismo y derechos humanos. Lima, IDEPUCP, 2006.

SANTOMÉ, J. T. As culturas negadas e silenciadas no currículo. In: SILVA, Tomaz Tadeu da (org). Alienígenas na Sala de Aula: uma introdução aos estudos culturais em educação. Petrópolis: Vozes, 1995, pp.158- 189.

SANTOS, B. S. Da idéia de universidade à universidade de idéias. In: Pela mão de Alice: o social e o político na pós-modernidade. 10a ed. São Paulo: Cortez; 2005. Cap. 8, p. 187-226.

SANTOS, M.; VEIGA, J.; SPYER, P. Os Pankararu do Estado de São Paulo. Relatório do GT FUNAI. São Paulo: FUNAI, 2000.

SEGATO, R. L. Racismo, discriminación y acciones afirmativas: Herramientas conceptuales. Brasília: UnB, 2006.

SILVA, C. T. Identificação étnica, territorialização e fronteiras: A perenidade das identidades indígenas como objeto de investigação antropológica e a ação indigenista. Revista de Estudos e Pesquisas (Fundação Nacional do Índio), Brasília, v. 2, n. 1, p. 
113-140, 2005.

SILVA, F. A B.; ARAÚJO, H. E.; SOUZA, A. L. Diagnóstico da situação das populações indígenas no Brasil. In: Anais do XV Encontro Nacional de Estudos Populacionais. Caxambu, 2006.

SILVA, T. T. Documentos de identidade: uma introdução às teorias do currículo. 2. ed. Belo Horizonte: Autêntica, 1999.

TUBINO, F. Educación, interculturalidad y buen gobierno. In: http://palestra.pucp.edu.pe/?id=206, 2006. (Acesso em 16 de julio de 2008).

VALENTE, A. L. Conhecimentos antropológicos nos parâmetros curriculares nacionais: para uma discussão da pluralidade cultural. In: GUSMÃO, Neusa Maria Mendes de (org.) Diversidade, cultura e educação. São Paulo: Biruta, 2003a.

VAZ FILHO, F. A. Identidade Indígena no Brasil Hoje. In: VII Congreso LatinoAmericano de Sociología Rural, 2006, Quito. La Cuestión Rural en América Latina: Exclusión y Resistencia Social Por un agro con soberanía, democracia y sustentabilidad, 2006.

VEIGA-NETO, A.; GIRARDELlo, G. Faces da diferença. Ponto de Vista (Revista de Educação e Processos Inclusivos), Florianópolis (SC), v. 5, p. 207-216, 2003.

VILHENA, J. A violência da cor. Sobre Racismo, alteridade e intolerância. Revista Electrónica de Psicología Política, v. 6, p. 1-19, 2007.

WIEVIORKA, M. Diferencias culturales, racismo y democracia. Em: D. Mato (coord.): Políticas de identidades y diferencias sociales en tiempo de globalización, Caracas: FACES-UCV, 2003.

\section{Outras referências}

\section{Jornais}

Folha de São Paulo, 07/08/1994.

Folha de São Paulo, 02/03/1997.

Folha de São Paulo, 08/11/1997.

Folha de São Paulo, 18/09/2000.

Jornal da Tarde, 07/05/2007.

Notícias Populares, 26/07/1994.

\section{CD de Música}


MATTA, Priscila. Índios Pankararu da comunidade Real Parque de São Paulo-SP. CD produzido por Alfredo Bello, para a série BPF Brasil Passado e Futuro, selo Mundo Melhor. São Paulo-SP, 2007.

\section{Vídeo (DVD)}

Agenda Indígena da Cidade de São Paulo. Direção: Diola de Carvalho. Agrofaces. São Paulo, 2007.

Das crianças Ikpeng para o mundo (Marangmotxíngmo Mürang). Direção: Kumaré, Karané e Natuyu Yuwipo Txicão. Vídeo nas Aldeias. São Paulo, 2001.

Do Outro Lado do Rio - Os Pankararu do Real Parque e a Cidade de São Paulo. Direção: Carolina Falcão Motoki. Universidade de São Paulo. São Paulo, 2005.

Do São Francisco ao Pinheiros. Direção: Paula Morgado e João Claudio de Sena. ONG Ação Cultural Indígena Pankararu e LISA (Laboratório de Imagem e Som em Antropologia) / USP (Universidade de São Paulo). São Paulo, 2007.

Educação Pankararu. Direção: Maira Ferreira. Universidade de São Paulo. São Paulo, 2008.

Eu venho do mundo. Dir. Marcos Albuquerque e Edson Nakashima. ONG SOS Comunidade Indígena Pankararu, USP (Universidade de São Paulo), UFSC (Universidade Federal de Santa Catarina) e FAPESP. São Paulo, 2008.

Na real do Real. Karina Santos. Favela Atitude. São Paulo, 2008. 